\title{
The Pyramidellidae (Gastropoda, Heterobranchia) of Norway and adjacent waters. A taxonomic review
}

\author{
Tore Høisæter'
}

\begin{abstract}
Høisæter T. 2014. The Pyramidellidae (Gastropoda, Heterobranchia) of Norway and adjacent waters. A taxonomic review. Fauna norvegica 34: 7-78.

This monograph gives a taxonomic treatment of all 54 'species' of Pyramidellidae reported from Norwegian and adjacent waters. Two species, Parthenina wikanderi n.sp.and Eulimella frielei n.sp., are described as new and three are 'resurrected' from synonymy. Nine previously described species are reported as new records for Norway, while three species are removed from the Norwegian fauna list. All species are illustrated with LM photographs (and, in a few cases, SEM photographs), and drawings of soft parts and operculae when available. An attempt is made to upgrade the generic taxonomy of the species included.
\end{abstract}

doi: 10.5324/fn.v34i0.1672. Recieved: 2014-07-01. Accepted: 2014-11-22. Published online: 2014-12-19. http://zoobank.org/urn:lsid:zoobank.org:pub:B52119CB-68B8-4F8D-B7D9-346360198476.

ISSN: 1502-4873 (printed), 1891-5396 (electronic).

Keywords: Heterobranchia, distribution, taxonomy, regional review, shell morphology, operculum, living animal

1. Tore Høisceter, Department of Biology, University of Bergen, PO Box 7800, N-5020 Bergen, Norway http://zoobank.org/urn:lsid:zoobank.org:author:8701A4E7-5BD0-4E70-8F68-ED4E51936B2F

E-mail:Tore.Hoisater@bio.uib.no

\section{INTRODUCTION}

The Pyramidellidae is a family of small, marine, heterobranch gastropods with a world-wide distribution. The members of this family are characterized by a small to minute, usually highspired shell, into which the specimen is completely retractible, a heterostrophic protoconch, a columella usually furnished with one (or, rarely, two or three) folds, generally called teeth, a horny, thin oligogyrous operculum, a long acrembolic proboscis and the lack of jaws and radula. In the 1940s, it was discovered that many, perhaps most of the species were ectoparasites mostly on polychaetes or molluscs. Many morphological traits point to a relationship with the Heterobranchia (heterostrophic protoconch; subepithelial eyes on the median side of the tentacles; penis often armed with cuticular teeth; 'opisthobranch' sperm morphology; 'opisthobranch' osphradial structure; and an ovotestis, e.g. Wise 1996). The presence in several species of spermatophores point in the same direction (Høisæter 1965, Robertson 1966, 1967, 1978). Recent molecular work (e.g. Dinapoli et al. 2011) however, indicates that the family is in fact deeply nested within the Pulmonata (see below).

The family is one of the most species rich gastropod families, with hundreds of European species named. It is regarded by many conchologists as a difficult group for identification purposes.

During field work in the middle 1960s (see Høisæter 1989), I became increasingly frustrated at not being able to rapidly and definitely identify many of the species on the basis of available literature. However, comparisons of several populations of living specimens convinced me that the presence of several good distinguishing characters previously overlooked made these specimens easily identifiable when alive. My material of living specimens, mostly collected in the 1960s and 1970s, are all from the area around the Marine Biological Station, Espegrend, Bergen (Korsfjorden, Fanafjorden, Raunefjorden, Grimstadfjorden, from c. $60^{\circ} 15^{\prime} \mathrm{N}$ to $60^{\circ} 20^{\prime} \mathrm{N}$ ). In the years since then, new material from all around the coast (with a few unfortunate gaps) has accumulated, and made a thorough revision of the Norwegian members of the family possible. 
The accumulated material of more than 35000 specimens is the basis for this review. The region covered is the Norwegian coast, the slope of the Norwegian Sea, and the Barents Sea adjacent to the Norwegian coast (Figure 1). Altogether 54 'species' belonging to at least 15 genera are treated. Two species are described as new.

\section{Historical survey}

The family Pyramidellidae was established by Gray in 1840 (Bouchet \& Rocroi 2005:148) with Pyramidella Lamarck, 1799 as type genus. This genus was erected for Trochus dolabratus Linnaeus, 1758, a large, tropical form, and one of three pyramidellid gastropods described by Linnaeus in the tenth edition of Systema Naturae. The other two species were Turbo lacteus, a shell which later authors have synonymized with Turbonilla elegantissima (Montagu, 1803) (see below), and Turbo striatulus, probably a Mediterranean Turbonilla. In 1777 Pennant described an unrecognizable British pyramidellid, Turbo albus, and in 1780 Fabricius described the arctic species Turbo albulus (= Menestho albula) from Greenland. With these exceptions, the generally small and inconspicuous northern pyramidellids did not attract the attention of the contemporaries of Linnaeus. The bulk of the species recognized today as living in northeast Atlantic waters, were described by a range of British conchologists in the first half of the $19^{\text {th }}$ century. These, starting with J. Adams (1797), Montagu (1803 and 1808), Donovan (1804), and Maton \& Rackett (1807), had by the year 1860 described at least 33 of the around 60 species from the northeast Atlantic.

The earliest workers of the Linnaean school assigned European pyramidellids to the genera Turbo, Voluta and Helix, until Fleming in 1813 erected the genus Odostomia for the members of the family Turbinidae with a 'tooth' on the columella. Odostomia was the first pyramidellid genus established since Lamarck's Pyramidella. Gradually, more and more pyramidellid genera were introduced during the first half of the century, of which the following have survived: Turbonilla Risso, 1826, Chemnitzia d'Orbigny, 1839, Pyrgiscus Philippi, 1841, Menestho Møller, 1842, Phasianema S. Wood, 1842, and Eulimella Forbes \& McAndrew, 1846. Most of these have European genotypes and are available for North-European species.

In the 1850's the field was in a mess, with more than 100 British species, and upward of 20 genera named. At this time Jeffreys made this group one of his favorites, and in a series of shorter articles he described several new species, as well as relegating scores of others to synonymy. In his 'British Conchology' (vol. 4, 1867), the British pyramidellid fauna was presented in a shape that has remained practically unaltered to this day, as far as the specific taxonomy is concerned. Jeffreys, however, in this and later works, adopted the extreme view that all (at least British) species of this family belonged in the genus Odostomia.

The first reports from Scandinavian waters are due to
Lovén (1846a,b). He mentioned 11 species from Scandinavian (mainly Swedish) waters, of which he described three as new (one, Turbonilla clavula, has survived). Malm (1855, 1861) presented additional information from the same area. The Danish fauna was first studied by Mørch (1871), whose investigations were continued by Collin (1880, 1884), and Petersen (1888). The more diverse Norwegian fauna was investigated by a long row of workers starting with M. Sars (1851, 1853, 1869, 1870), Asbjørnsen (1854), McAndrew \& Barrett (1856), Danielssen (1861), Jeffreys (1870), Brøgger (1872), Friele $(1874,1876)$, Verkrüzen $(1874,1875)$, G.O. Sars (1878), Norman (1879, 1892, 1903), Friele (1886), Schneider (1886), Grieg (1888, 1897), Appellöf $(1896,1897)$ and Friele \& Grieg (1901). After the turn of the century, little serious faunistic work on pyramidellids have been done in Norway, but incidental records appear in Nordgaard $(1905,1913)$, and Grieg (1914). Quaternary fossils were treated by M. Sars (1865), Brøgger (1901), Kolderup (1908), and Kaldhol (1909). In later years pyramidellids have received very little interest from modern workers, until 'rediscovered' by Høisæter $(1965 ; 1968$; 1989, 2009), Warén (1991), and Schander (1995, 1997).

G.O. Sars (1878) was the first to publish a comprehensive list of all known Norwegian species. He named 27 species which he placed in six genera, one of which, Liostomia, he named as new. He described and presented drawings of 16 species, three of which he described as new. These 16 species were the ones he found in the 'arctic' region of the Norwegian coast, by him defined roughly as the coast north of the Arctic Circle $\left(66^{\circ} 33^{\prime} \mathrm{N}\right)$. This may be the first attempt to publish a revision of northeast Atlantic pyramidellids since Jeffreys' (1867). No further revisions or descriptive works including Norwegian species were published until Nordsieck (1972) undertook the herculean task of revising all the marine mollusks of Europe, including the Mediterranean. His work, which together with his two companion volumes, is the only complete overview of the European marine Mollusca to date, has however been heavily criticized by, among others van Aartsen (1977:49) and Smith \& Heppell (1991:2). I fully agree that the work of Nordsieck should be used with care, but all his suggested names are nomenclaturically available, and should be carefully compared with relevant alternatives. One of the pyramidellids he described, Parthenina sarsi, is accepted as a valid species. In 1977 van Aartsen began a series of revisions of all recognized European pyramidellid species, including those from the Mediterranean. The series was continued in van Aartsen (1981, 1987) and completed in van Aartsen (1994). These revisions were based on studies of the type material (when available) and comparison with the original descriptions. The oldest part, the revision of Chrysallida s.l. was supplemented and updated by van der Linden \& Eikenboom (1992) and further revised by Micali et al. (1993). In the meantime Warén (1991) had revised six genera from the northern parts of the northeast Atlantic. In this work (in which Odostomia s.l. and Turbonilla s.l. are not included) Warén described six new species, but retained more 
or less the classical, admittedly artificial, generic subdivision. Fretter et al. (1986) exploited the illustrations (by the Danish artist Poul Winther) left by Gunnar Thorson for his planned Fauna of Denmark and the British Isles, for an identification guide of all species known from British and Danish waters. This guide also contains summaries of what is known of the biology of each species. The illustrations and specific descriptions from this work were transferred almost unaltered to the identification guide by Graham (1988). For practical purposes, the synopsis by Graham is so far unsurpassed for specific identification of northeast Atlantic pyramidellid gastropods.

The present work is an attempt to improve the systematics of the Pyramidellidae in Scandinavian waters and relies heavily on the revisions by van Aartsen and Warén.

In the various check-lists published during the last 100 years, the species names are largely the same as those used by Jeffreys (1867). Thus the influential check-list for the British Isles by Winckworth (1932) disagrees with Jeffreys in the naming of only seven (pyramidellid) species. Most of these seven have been disputed to this day, and no agreement seems to be within reach yet. Høisæter (1986) accepted almost all the names of Winckworth, and did not contribute to any clarification of the debatable points. Smith \& Heppell (1991) is a thorough and well-argued check-list including both (most of) the northern and deep water forms, as well as the novelties introduced by van Aartsen (1977, 1981, 1987), but lacking the new species introduced in Warén 1991. Høisæter (2009) is so far the newest check-list of Norwegian pyramidellids, and contains all the new information introduced in the papers by these authors, but makes no attempts to clarify the nomenclatural problems, using CLEMAM (Check List of European Marine Mollusca) (2009) as a standard for the nomenclature.

The generic taxonomy of this family is still in a chaotic state, as is evident from a comparison of some of the newer checklists. While Høisæter (2009) use the broadest conchologically based genus names (altogether nine genera) and refrain from the use of subgeneric names, Smith \& Heppell (1991) operates with 22 subgenera within 15 genera for roughly the same geographical area. There is general agreement, however, that the generic subdivision is highly artificial and needs a profound reshaping.

What was known of pyramidellids up to about 1870, was mainly based on shell morphology. However Lovén (1846a), Alder (1848), Forbes \& Hanley (1850-51), Clark (1855), and Jeffreys (1867) already described the soft parts of some species, but these charateristics are hardly incorporated in the taxonomy of today. Robertson (1978) based his generic taxonomy mainly on 'biological' characters, many of them connected to spermatophores. The only conchological characters he considered of value for distinguishing between two eastern North American odostomioid genera, were shell size, the number of protoconch whorls and the degree of heterostrophy. In general he expressed a pessimistic view concerning the usefulness of conchological structures for the supraspecific phylogenetic classification of pyramidellids. In contrast the indispensable value of using both anatomical and conchological characters for the classification of pyramidellids has been amply demonstrated in Wise (1996), Schander et al. (1999b) and Schander \& Sundberg (2001).

In recent years, the Pyramidellidae is generally recognized to be sufficiently systematically diverse to justify a family level subdivision. Thus Smith \& Heppell (1991) (following Ponder \& Warén 1988) divide the northeast Atlantic species into four subfamilies. Ponder \& Bouchet (in Bouchet \& Rocroi 2005) follow Schander et al. (1999a) in recognizing four subfamilies (as families in Schander et al. 1999a) similar to but not identical to the ones of Smith \& Heppell. In Ponder \& Bouchet these are divided into 11 tribes. The molecular work of Schander et al. (2003) provides some support for this division, but the number of taxa (32 species) included, was far too limited to provide a comprehensive classification. A more recent attempt to test the monophyly and phylogeny of the Pyramidellidae by molecular means (Dinapoli et al. 2011), included nine species (six Odostomiinae and three Turbonillinae) in an extended set of heterobranch taxa. The analysis supports the monophyly of both the two subfamilies as well as the family, but not the placement at the base of the Heterobranch clade as 'Lower Heterobranchia'. They found it to be deeply nested within Pulmonata with the freshwater group Glacidorboidae or the estuarine Amphiboloidea as possible sister taxa. Although I suspect that future studies will support the elevation of the subfamilies into full families (as done by Schander et al. 1999a), I use the subfamilies as defined in Ponder \& Bouchet (in Bouchet \& Rocroi 2005), only two of which are represented in our waters, viz. Odostomiinae and Turbonillinae.

According to Ponder \& Bouchet (in Bouchet \& Rocroi 2005) the superfamily Pyramidelloidea is composed of the Pyramidellidae and the smaller families Murchisonellidae and Amathinidae. Murchisonellidae has one recognized member in our waters, Ebala (or Anisocycla) nitidissima, and a possible member in Bacteridium sp. (see discussion under 'Bacteridium' below). Two members of Murchisonellidae (including Ebala, but not Bacteridium) have recently been included in a molecular analysis together with three pyramidellids, and were found to be unrelated to the pyramidellids (Dinapoli \& Klussmann-Kolb 2010). According to this study the Murchisonellidae should be excluded from the superfamily Pyramidelloidea. For this reason, Ebala nitidissima is not treated in this work.

\section{MATERIAL, SAMPLE SITES AND METHODS}

Most of the material studied here consists of gastropods collected alive (more than 34000 specimens) from the area around the Biological Station of the University of Bergen. Most are from three fairly shallow water localities as parts of more extensive benthic investigations (regular collecting throughout the year among other things). These three localities are characterized 
by strong currents, permitting heavy 'fouling' growth (mainly serpulid polychaetes) on hard subtrates. At one of these localities also very dense populations of several bivalves, Modiolus modiolus, Limaria hians, and Hiatella arctica were found. These organisms constitute ideal substrates for the pyramidellids (cf. Høisæter 1989). In addition to this, incidental records from Korsfjorden, Raunefjorden and Hjeltefjorden in the vicinity of the Biological Station, mainly from the period 1965 to 1973, are included. Most of these incidental records are donated by Anders Warén, who in the period 1968 to 1973 performed extensive surveys of the mollusc fauna in the area, mainly in the outer fjords and on the continental shelf (cf. e.g. Warén 1991). Also included are the pyramidellids found during a faunistic study of the epifaunal community on stipes and hapteres of kelp (Laminaria hyperborea) seasonally at a locality outside Sotra $\left(60^{\circ} 10^{\prime} \mathrm{N}\right)$ in 1992. Two surveys in Fensfjorden and adjacent fjords in 1971 and 1989 respectively, brought to light a limited but interesting collection of pyramidellids.

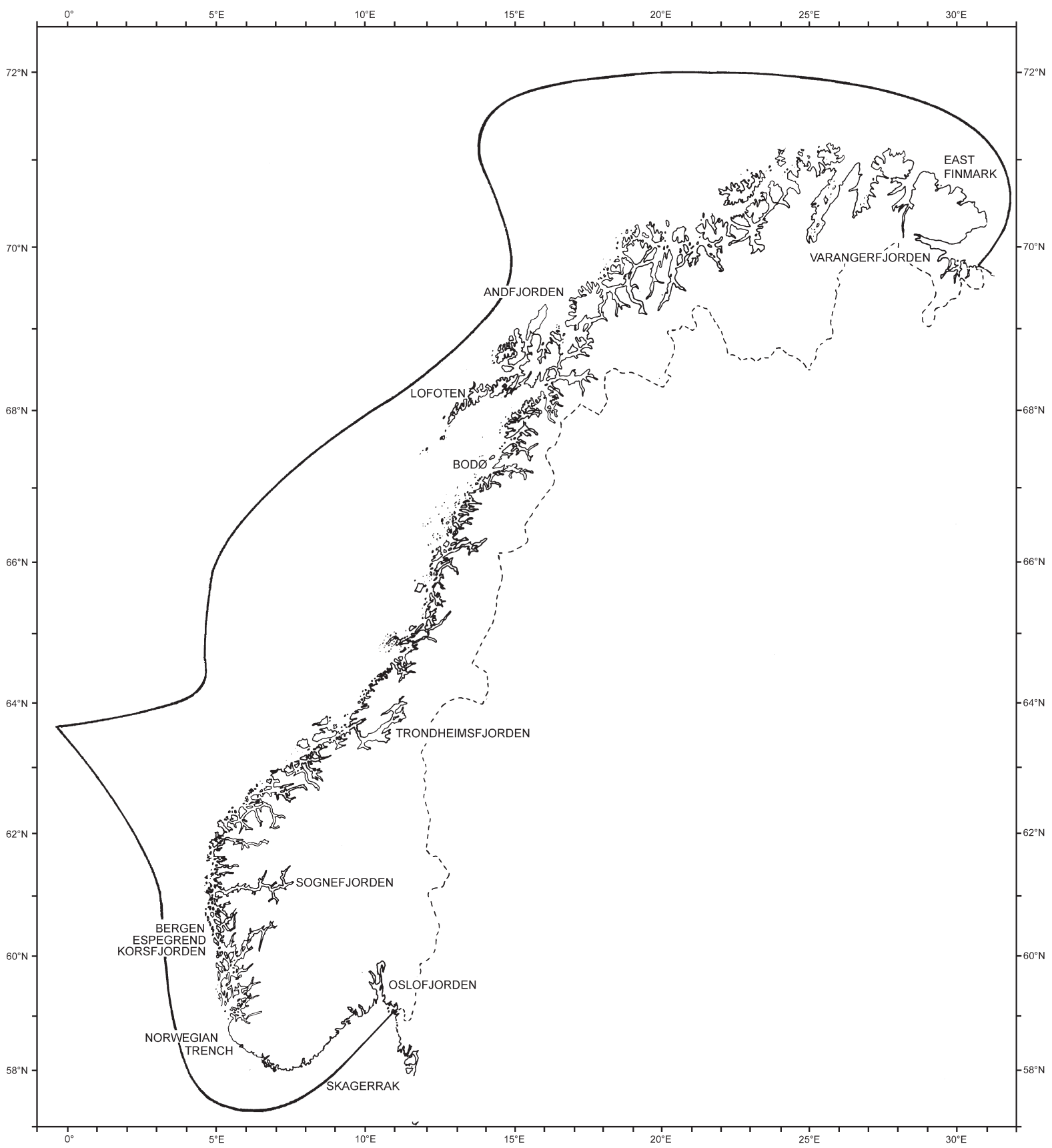

Figure I. Map of the area covered, the coast of Norway and the shelf and slope off Norway. From Høisæter 2009. 
A series of cruises along the northern and northwestern coasts of Norway, from Andfjorden and the fjords southeast of Andfjorden (1968), Nordland and Nord-Trøndelag (1969), to Møre og Romsdal (1970), and finally another trip to Nordland/ Nord-Trøndelag (1971), all provided invaluable material for the elucidation of the variation and distribution of the various species (see Høisæter 2009 for further details).

Per Bie Wikander, has, in the period 1970-1989 collected shell-bearing molluscs both in the Skagerrak area and in northern Norway (Nordland County), and kindly put the pyramidellids at disposal. I have also benefited from the accumulated material of Per Johannessen, who sampled many localities from Lysefjorden to Kristiansund $\mathrm{N}$ in the period 1980-1987. All the material mentioned is deposited in the University Museum of Bergen, Natural History Collections. Below, this material is consistently referred to as 'my material'.

Most of the pyramidellid material in the University Museum of Bergen, Natural History Collections was also studied, e.g. the material from the Norwegian North Atlantic Expedition of 1876-1878 (Friele \& Grieg 1901), and other material collected and identified by Friele (Friele 1874, 1876). These are recorded as ZMBN-stations below. Other museum abbreviations used in the text: BMNH (Museum of Natural History, London); HMAC (Hancock Museum, Alder collection); MNHN (Muséum national d'Histoire naturelle, Paris); NHMO (Natural History Museum, University of Oslo); RAMME (Royal Albert Memorial Museum, Exeter); SMNH (Swedish museum of Natural History); USNM (United States National Museum, Washington DC); ZMUC (Zoological Museum, University of Copenhagen).

A standard notation for the geographical region from which the relvant material was taken is used in 'Material seen' below: Skagerrak refers to the southern coast of Norway, south of $59^{\circ} \mathrm{N}$ (almost exclusively material donated by Per Bie Wikander); Hordaland from $60^{\circ}$ to $61^{\circ} \mathrm{N}$, is where the majority of live caught specimens were found; Møre og Romsdal from $62^{\circ}$ to $63^{\circ} 20^{\prime} \mathrm{N}$; Nord-Trøndelag, $64^{\circ} 25^{\prime}$ to $65^{\circ} \mathrm{N}$; Nordland, $65^{\circ} 30^{\prime}$ to $67^{\circ} 15^{\prime} \mathrm{N}$; Troms, $68^{\circ} 38^{\prime}$ to $69^{\circ} 25^{\prime} \mathrm{N}$, actually the region of Andfjorden and the fjords further inland; while the few records from the Norwegian Trench are always specified with latitude and depth.

The main part of this revision is based on LM photographs of representatives of all species encountered. The photographs were taken under a stereo microscope with an Olympus, 4.1 Mpix. digital camera, and processed in Adobe Photoshop (TM) by the author. Specimens were measured with an ocular micrometer in a Leitz RS binocular microscope, and are represented to the nearest $0.1 \mathrm{~mm}$. Drawings were made by the help of a drawing mirror on a Wild M5 stereo dissecting microscope, as well as on the above mentioned Leitz microscope. A few species mentioned in the literature for which I have not access to any material is represented by illustrations (SEM photos or drawings) taken from various sources.

As mentioned, virtually all attempts to classify the pyramidellids into supraspecific categories, have so far been based on a limited number of shell characters, of which the most popular have been: Number of columellar 'teeth'; shell sculpture; the angle of inclination of the heterostrophic protoconch, as well as its degree of submergence in the teleoconch, and its size and shape; and the relative height of the shell. In recent revisions (e.g. Fretter et al. 1986; van Aartsen 1987), also the direction of the growth lines (prosocline, opisthocline or orthocline) has been used. Van Aartsen (1987) also use the presence or absence of a clear, well-formed umbilicus; and presence or absence of teeth on the inside of the outer lip as specific characters.

Degree of inclination and size of protoconch, have been well described by Fretter et al. (1986) and van Aartsen (1987), and this character is here also accepted as of phylogenetic importance. Van Aartsen (1987) classifies the protoconch into three basic types: Type A) in which the protoconch whorls are completely exposed on top of the shell axis, at an angle of $90^{\circ}$; type B) in which the protoconch is partly concealed, at an angle of about $135^{\circ}$ with the shell axis; and type C) usually called inverse, or 'intorted', in which most or all of the top whorls lies concealed in the teleoconch. Even shells with type A protoconchs may have the protoconch partly submerged in the topmost teleoconch whorl. The protoconch may be either helicoid or planorboid.

Useful nonconchological characters for the Norwegian pyramidellids are the shape of the foot, shape of the mentum (a thin, lobed process between the head and the anterior part of the foot), tentacle shape, presence or absence of ciliated 'pad' at ventral side of the tip of tentacle, and size of and distance between eyes (Figure 2).

The morphology of the operculum (Figure 3 ) and the colour of the pigmented mantle organ (Figures 4 and 61) are two useful characters for identification purposes, and also thought to be of phylogenetic value. To improve the attachment to the muscles of the foot, the operculum has either an unspecified thickening

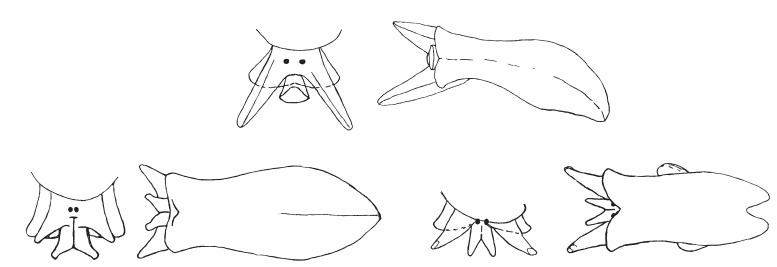

Figure 2. Head-foot complex of (from top and left to right) Odostomia turrita, 'Brachystomia' lukisi, and Ondina divisa.

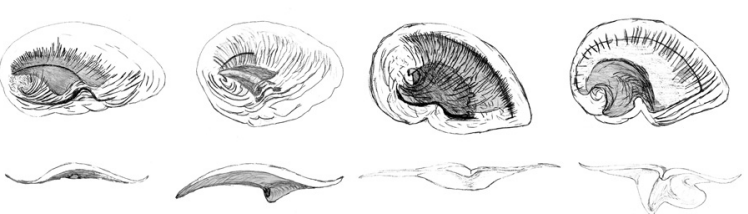

Figure 3. Operculae from four species of odostomine pyramidellids. From left, Brachystomia scalaris, Parthenina interstincta, 'Brachystomia' lukisi, Odostomia acuta. 


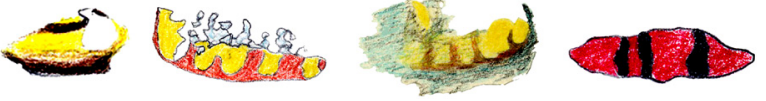

Figure 4. Pigmented mantle organs of (from left) Parthenina interstincta, Odostomia striolata, O. unidentata, and O. turrita (not to scale).

('Brachystomia' lukisi and Brachystomia scalaris), is provided with a channeled or tubelike internal 'process' (Spiralinella spiralis and Parthenina interstincta respectively) (see Figure 3), is completely flat (species of Ondina and Liostomia), or is supplied with a narrow, curved ridge (members of Turbonillinae, see Figure 112). In Odostomia s.s. the operculum attachment to the foot is most highly developed, a strong internal tooth-like 'process' (below called operculum 'anchor') (See Figure 3 right). This is differently developed in different species and may in principle be used for identification purposes, but can only be properly studied if the soft parts are removed. The operculum in many cases have other peculiarities that are of systematic importance, as e.g. a notch on the columellar side, found in the species with a fairly strong 'tooth' on the columella.

The pigmented mantle organ is both of generic, and specific importance. It is often possible to see this organ even if the animal is retracted in its shell (when the shell is translucent; see Figure 61). The Norwegian species of Odostomia s.s. each have a species specific pigmented mantle organ, while species of Brachystomia and Parthenina all seem to have varieties of the same colour-pattern. In the remaining groups too few species have been observed to present any general pattern. Figure 4 shows four characteristic pigmented organs.

\section{Variability}

The usefulness of shell morphology for taxonomic purposes depends heavily on the degree of variability, both within genera and within species. Traditionally (e.g. Fretter et al. 1986) the intergeneric variability is considered small enough for a specimen to be easily assigned to correct genus, whereas the interspecific variability is generally high ("To assign a given shell to a genus is relatively straightforward, to be sure to which species of that genus it belongs is more difficult and, in more variable species, it may be hard to be certain of identification unless a range of shells is available for comparison." Fretter et al. 1986:558). This conclusion of course depends on the genus concept used. If the genus is based purely on the macroscopic shell features mentioned above, the generic assignment is fairly easy. Whether these genera are phylogenetically 'valid' is another matter, and is hotly debated. Robertson (1978, 1996) and Wise $(1996,2001)$ united a range of both slightly sculptured and heavily cancellated pyramidellids from the east coast of North America into two genera, Boonea and Fargoa, where species in one genus might have shell sculpture indistinguishable from a species assigned to the other. Within each species, the variability was regarded as low, although one species, Fargoa bartschi (Winkley, 1909) was shown to have a wide range of different shell morphologies (Robertson 1996). Heavily sculptured taxa, like several species of Turbonilla s.l., are notorious for their intraspecific variability (e.g. Wharton 1976), and the extremes of many taxa are sufficiently different for their specific assignment to be highly debatable. The conchological variability is certainly no less for the more or less unsculptured species of pyramidellids (specimens assigned to Ondina are particularly hard to classify), and as the various reviewers have been rather reluctant to describe in detail the diagnostic characters of their 'species', there is ample room for disagreement on the specific limits for several of the forms encountered. The same goes for the specific names, as the type specimens for the older names are usually in poor condition and rarely of any help. (I have included very good photographs of G.O. Sars' holotypes of both Ondina coarctata and Odostomia turgida, and for both the shell surface was affected by 'glass disease', obscuring any sculptural details that might be present). Thus much space below is used for discussing which specific name should be adopted for each recognizable taxon in my material. A final problem repeatedly encountered is the lack of type specimens of species named early in the $19^{\text {th }}$ century. See e.g. 'Remarks' for Parthenina indistincta below.

The taxon names used in this review are:

Odostomiinae Pelsneer, 1928

Parthenina Bucquoy, Dautzenberg \& Dollfus, 1883.

Parthenina indistincta (Montagu, 1808)

Parthenina interstincta (J. Adams, 1797)

Parthenina sarsi (Nordsieck, 1972)

Parthenina wikanderi n.sp.

Spiralinella Chaster, 1901.

Spiralinella spiralis (Montagu, 1803)

Chrysallida s.l. Carpenter, 1856

Chrysallida bjoernssoni Warén, 1991

Chrysallida brattstroemi (Warén, 1991)

Chrysallida eximia (Jeffreys, 1849)

Chrysallida hoeisaeteri Warén, 1991

Chrysallida sublustris (Friele, 1886)

Brachystomia Monterosato, 1884

Brachystomia angusta (Jeffreys, 1867)

Brachystomia carrozzai (van Aartsen, 1987)

Brachystomia eulimoides (Hanley, 1844)

Brachystomia scalaris MacGillivray, 1843

'Brachystomia' lukisi Jeffreys, 1859

Odostomia Fleming, 1813

Odostomia acuta Jeffreys, 1848

Odostomia umbilicaris (Malm, 1861)

'Odostomia' conoidea (Brocchi, 1814)

Odostomia conspicua Alder, 1850 
Odostomia plicata (Montagu, 1803)

Odostomia striolata Forbes \& Hanley, 1850

Odostomia turgida G.O. Sars, 1878

Odostomia turrita Hanley, 1844

Odostomia unidentata (Montagu, 1803)

Jordaniella Chaster, 1898

Jordaniella nivosa (Montagu, 1803)

Jordaniella truncatula (Jeffreys, 1850)

Ondina de Folin, 1870

Ondina coarctata (G.O. Sars, 1878)

Ondina divisa (J. Adams, 1797)

Ondina divisa cf. rubra

Ondina divisa nobilis (G.O. Sars, 1878)

Ondina warreni (Thompson, 1845)

Ondina diaphana (Jeffreys, 1848)

Ondina perezi (Dautzenberg \& Fischer, 1925)

Ondina normani (Friele, 1886)

Ondina obliqua (Alder, 1844)

Liostomia G.O. Sars, 1878

Liostomia afzelii Warén, 1991

Liostomia clavula (Lovén, 1846)

Liostomia eburnea (Stimpson, 1851)

Liostomia hansgei Warén, 1991

Rissopsetia Dell, 1956

Rissopsetia islandica Warén, 1989

Aartsenia Warén, 1991

Aartsenia candida (Møller, 1842)

Turbonillinae Bronn, 1849

Eulimella Forbes \& MacAndrew, 1846

Eulimella laevis (Brown, 1827)

Eulimella ataktos Warén, 1991

Eulimella compactilis (Jeffreys, 1867)

Eulimella scillae (Scacchi, 1835)

Eulimella ventricosa (Forbes, 1844)

Eulimella frielei $\mathrm{n} . \mathrm{sp}$.

Turbonilla Risso, 1826

Turbonilla lactea (L., 1758)

Turbonilla pusilla (Philippi, 1844)

Pyrgiscus Philippi, 1841

Pyrgiscus rufus (Philippi, 1836) [= P. crenatus (Brown, 1827)?]

Pyrgiscus fulvocinctus (Thompson, 1840)

Pyrgiscus jeffreysii (Forbes \& Hanley, 1850-51)

Pyrgiscus rufescens (Forbes, 1846)
INCERTAE SEDIS

Bacteridium Thiele, 1929

Bacteridium cf. carinatum (de Folin, 1870)

\section{TAXONOMY}

Superfamily Pyramidelloidea

Family Pyramidellidae

Two subfamilies, Odostomiinae and Turbonillinae, are represented in our waters.

\section{Subfamily Odostomiinae Pelseneer, 1928}

Pyramidellids with comparatively short, more or less conical or pupoid shells with (at most) a single columellar 'tooth' and protoconch either exposed (type A) or more or less concealed (type B and C) in first teleoconch whorl.

Based on a few easily observed shell characters, the northeast Atlantic species have been classified as belonging to either Odostomia (without macroscopic sculpture), Chrysallida (with mainly axial sculpture) or Menestho (with only spiral sculpture). These three genus names were used by Winckworth (1932) and adopted by Høisæter (1986). The three genera were subdivided into subgenera, however. Chrysallida was divided into Partulida and Parthenina, Menestho into Evalea and Liostomia, and Odostomia into Odostomia s.s. and Brachystomia. These subgenera have all been elevated to full generic rank by later authors (e.g. Fretter et al. 1986), although Evalea and Partulida have since been changed to Ondina and Spiralinella respectively. Fretter et al. (1986) also removed Jordaniella from Odostomia and re-established it as an independent genus. Van Aartsen $(1977,1987)$ disagreed and re-established Chrysallida, Odostomia and Ondina as the only European odostomine genera. Warén (1991), used Chrysallida, Ondina and, as did Fretter et al. (1986), found Liostomia, sufficiently distinct to separate it from Odostomia (he did not include Odostomia s.l. in his revision). Smith \& Heppell (1991) accepted the generic taxonomy of Fretter et al. (1986). Schander (1995) in his revision of the pyramidellids of the Faroes, used van Aartsen's (1987) taxonomy as a basis for his small sample, but accepted Brachystomia as a genus, not a subgroup of Odostomia. Høisæter (2009) adopted the current use of names in CLEMAM, and used Chrysallida, Odostomia, Ondina and Liostomia, but mentioned briefly also the rare Rissopsetia and Aartsenia.

In this review, I include the following Norwegian 'genera' in this subfamily (but see Discussion on p. 125):

Odostomia - Shells smooth or with microscopic striation, 
protoconch angle usually $90^{\circ}$ (exceptionally $110^{\circ}$ to $135^{\circ}$ ), operculum with notch and internal process; no tentacular pads.

Brachystomia - Shells with at most microscopic sculpture, protoconch more or less intorted, operculum without notch or internal process; tentacles with tentacular pads.

('Brachystomia' lukisi) - Shell smooth and polished, protoconch intorted and extremly flat, no tentacular pads.

('Odostomia' conoidea) - Shell smooth and polished, protoconch angle $110^{\circ}$ and partly submerged, sometimes with inside of outer lip with several spiral ridges, columellar tooth prominent.

Ondina - Thin-shelled forms with opisthocline growth lines, intorted protoconch, with or without fine spiral sculpture.

Liostomia - Small, smooth, almost cylindrical shells lacking a columellar tooth.

Jordaniella - Shell small, almost cylindrical with indistinct spiral sculpture. Blunt apex.

Parthenina - Shell sculptured with axial ribs and a limited number of spiral lirae on lower part of each whorl, protoconch intorted, tentacles with tentacular pads. At least some species with spermatophores.

Spiralinella - Shell sculptured with axial ribs, spiral cords limited to the base of body whorl, protoconch intorted, tentacles with tentacular pads.

('Chrysallida' eximia) - Shell small, with prominent axial, prosocline ribs and three spiral cords. Whorls convex with deep suture. (Three species in Norway. 'C.' bjoernssoni, ' $C$.' brattstroemi and ' $\mathrm{C}$.' hoeisaeteri are probably closely related to ' $C$ ' eximia).

('Chrysallida' sublustris) - Shell sculptured with wavy axial 'ribs', no spiral sculpture.

Rissopsetia - Shell cylindrical, small, high and solid. Protoconch inflated

Aartsenia - Large shell with dominating body whorl, smooth and glossy shell.

Of these, Parthenina, Spiralinella, Chrysallida s.l., Brachystomia, Ondina and Liostomia, based on protoconch morphology (intorted), general colouration of pigmented mantle organ, type of operculum and the presence of tentacular pads (missing in all other genera in the Norwegian fauna) belong in a separate clade, corresponding to the informal group, Liostomini in Schander et al. (2003). Lack of observations of living specimens of Jordaniella, Rissopsetia and Aartsenia prevents placement of these groups. Based on molecular data (mitochondrial 16S partial gene), Jordaniella should, however, belong in the same clade as Liostomia (Schander et al. 2003).

In the list above, four groups are singled out as belonging to so far unnamed genera. I refrain from naming these, as the possibility of further confusing the already chaotic generic taxonomy of the family is too great.

To facilitate the practical work of identifying members of this 'difficult' subfamily, keys are given for the genera, and also for the species within each of the species-rich genera.

Key to the genera of Odostomiinae, based on shell morphology

1a. Shell smooth or with fine spiral sculpture

1b. Shell with prominent axial sculpture

2a. Protoconch angle usually around $90^{\circ}$ (Type A)

(exceptionally $110^{\circ}$ to $135^{\circ}$ )

2b. Protoconch more or less intorted (type B and C) ............3

3a. Protoconch intorted, completely flat, $180^{\circ}$ (type C), shell smooth and polished (porcellaneous) ..('Brachystomia' lukisi)

3b. Protoconch intorted, around $150^{\circ}-170^{\circ}$ (type B) ..............

4a. Shell delicate, thin, with fine spiral sculpture or completely smooth, opisthocline growth lines, elongated aperture. Ondina

4b. Shell different.. . .5

5a. Shell solid, no sculpture Brachystomia

5b. Small, smooth, almost cylindrical shells, lacking a columellar fold Liostomia

5c. Shell cylindrical, with a few or many indistinct (low and wide) spiral ridges Jordaniella

5 d. Shell with very weak axial ribs or growth lines, protoconch inflated Rissopsetia

6a. Shell with wavy, poorly defined, axial ribs, no spiral sculpture. Protoconch inflated ('Chrysallida' sublustris)

6b. Shell with clearly defined axial ribs, from three to many spiral cords . .7

7a. Spiral cords restricted to base, below axial ribs ...Spiralinella

7b. Two to several spiral cords on lower parts of whorls, usually seen only in interspaces between the axial ribs Parthenina

7c. Three spiral cords crossing prosocline axial ribs below periphery of each whorl

$$
\text { 'Chrysallida' eximia (and 'relatives') }
$$

\section{Genus - Chrysallida Carpenter, 1856 s.l.}

Type species by original designation, Chemnitzia communis C.B. Adams, 1852. Pacifc coast of Panama.

The introduction of Chrysallida as the genus name for this extended group is probably due to Thiele (1929). Earlier authors used the name in a more restricted sense, mostly as a subgenus or section. Thiele apparently adopted the name from Dall \& 
Bartsch (1904), as the oldest of the names used by these authors for members of Odostomia (sensu Dall \& Bartsch) with axial sculpture. The name was originally introduced by Carpenter (1856) for a group of East Pacific, somewhat pupiform shells with flattened whorls, heavy nodulous sculpture (axial ribs crossed by spirals of equal strength) and several basal cords. The first to adopt this genus name for our European species was apparently Winckworth (1932), who followed Thiele (1929) in this case. Since that time it has remained in the European literature, as the name for most European smaller pyramidellids with both spiral and axial sculpture and with an intorted protoconch. All authors of recent revisions (e.g. Warén 1991, Schander 1995 and van Aartsen et al. 2000) agree that Chrysallida is a heterogeneous group, but as no global revision of this large group has been made they refrain from using any other genus names for species living in our waters. As Chrysallida, both because of its type species from the tropical eastern Pacific, and its characteristic nodulous sculpture is unlikely to have any close relatives in our waters (see however van Aartsen et al. 2000), I propose that the majority of the Northeast Atlantic species should be grouped together in Parthenina. Spiralinella is not included due to its deviating mitochondrial16S gene (Schander et al. 2003). There are still a number of species with deviating sculpture (soft parts unknown) which may validate the placement in a new genus. Until they are better known, I keep these few species in Chrysallida s.l.

\section{Parthenina Bucquoy, Dautzenberg \& Dollfus, 1883}

Type species by original designation: Turbo interstinctus Montagu, 1803; Britain

\section{Synonyms:}

Chrysallida auct. not Carpenter, 1856

Parthenia Lowe, 1841 not Robineau-Desvoidy, 1830

Partulida Schaufuss, 1869

Pyrgulina A. Adams, 1864 (in part)

Pyramidellids with small $(<5 \mathrm{~mm}$ long), elongate-ovate to truncated, conical shells, of not more than six whorls. Sculpture consisting of axial ribs, usually in combination with spiral sculpture, either raised threads, or striae. Columellar fold always present, though sometimes rather indistinct. Protoconch medium-sized to small, more or less intorted. Operculum (Figure 3) oligogyrous, moderately thick, with no indentation for the columellar fold. Yellowish, internal process of moderate thickness, gradually decreasing in thickness towards the opercular edges from the walls around a central, slightly arched 'tunnel'. Foot long and narrow, truncated anteriorly and ending in a blunt point (Figure 9). Tentacles triangular with tentacular pads at their tip. Eyes moderately large and rather far apart. Mentum narrow with a squarish front. Pigmented mantle organ irregularly oval to circular consisting of yellow and brown patches (Figure 9). Following Schander et al. (2003) I adopt Parthenina as the name for most European "Chrysallida" species.

In the region here covered, this genus is represented by four or five species. However, the number of species is far higher further south, in the Mediterranean and the Canary Isles (van Aartsen 1977, van der Linden \& Eikenboom 1992, Peñas et al. 1996, van Aartsen et al. 2000).

Key to the species of Parthenina, based on shell morphology

1a. Shell with one or two spiral cords near base of each whorl .2

1b. Shell with more than two spiral cords on body whorl ....3

2a. Whorls somewhat flattened, surface glossy, without periostracum ..Parthenina interstincta

2b. Whorls distinctly convex, with periostracum ..Parthenina wikanderi

3a. Shell narrow and tall, with four to seven spirals on body whorl .Parthenina indistincta

3b. Shell wider than $P$. indistincta, and with at least eight spirals on body whorl Parthenina sarsi

Parthenina indistincta (Montagu, 1808) Figure 5

Turbo indistinctus Montagu, 1808:129

Parthenia indistincta (Montagu) - Thompson 1844; Collin 1884; Petersen 1888

Chemnitzia indistincta (Montagu) - Alder 1848; Forbes \& Hanley 1850-51; Clark 1855; M. Sars 1870; Friele 1874; Jeffreys 1884; Marshall 1900

Odostomia indistincta (Montagu) - Jeffreys 1867

Turbonilla indistincta (Montagu) - G.O. Sars 1878

Turbonilla (Chemnitzia) indistincta (Montagu) - Malm 1861

Parthenina indistincta (Montagu) - Kobelt 1903

Chrysallida indistincta (Montagu) - van Aartsen 1977; Fretter et al. 1986; Graham 1988; Smith \& Heppell 1991; Warén 1991; van der Linden \& Eikenboom 1992; Micali et al. 1993; Peñas et al. 1996; Høisæter 2009

Chrysallida (Parthenina) indistincta (Montagu) - Winckworth 1932; Høisæter 1986; van Aartsen et al. 2000

Type material: Not found (Warén 1991)

Type locality: "Found in the Boysian cabinet". Probably the coast of Kent (fide Parker \& Jones 1860:335)

Material seen: Norway - Skagerrak, 2 spms; Hordaland, several shs; Møre og Romsdal several shs; Nord-Trøndelag, several shs; Nordland, 2 spms and several shs.

Diagnosis: Shell: Fairly long (max. length $3.7 \mathrm{~mm}$ ), narrow, almost cylindrical shells, superficially Turbonilla-like, with 
slightly convex whorls, and with 11 or 12 (visible) flexuous axial ribs crossed by four to seven spiral cords on the body whorl. Very weak columellar fold, not visible within aperture. Protoconch small, intorted. Soft parts: The colour of preserved specimens as seen through the shell is reddish orange, and the eyes are very small and close together. Operculum: Not studied.

Biology: Not known.

Distribution: Reported as rare from the Bergen area by Friele (1874) (not refound by Norman 1879 in the same area), from Oslofjorden by G.O. Sars (1878) (also reported by M. Sars 1865 , and Brogger 1872, but not recorded by Jeffreys 1870), while Warén (1991) only records two specimens (Bergen) and one shell (Raunefjorden) as Norwegian material. In my material two specimens and three shells from Skagerrak, two specimens and an additional 18 shells (or fragments) of which two specimens and 16 shells from between $65^{\circ} 30^{\prime} \mathrm{N}$ and $67^{\circ} 05^{\prime} \mathrm{N}$. Except for the two specimens, beautifully preserved, from outer Vefsnfjorden $\left(65^{\circ} 53^{\prime} \mathrm{N}, 12^{\circ} 32^{\prime} \mathrm{E}, 12-15 \mathrm{~m}\right.$, Desmarestia and Lithothamnion and other red algae) the shells are often worn, with much of the spiral sculpture hard to see. As shells are easily confused with $C$. interstincta, the identifications of the 10 samples included can not all be trusted. The material from Vefsnfjorden and two shells from Sjonafjorden, just south of Sila $\left(66^{\circ} 17^{\prime} \mathrm{N}, 160-80 \mathrm{~m}\right.$, gravel) are perhaps the most reliable. The material from Sjonafjorden is also the northernmost record of this species so far. Outside Norway it is reported as common in the Koster area in the Swedish part of Skagerrak (Warén 1991). Further south the species is distributed along the Atlantic coasts of Europe, from the North Sea to Portugal and the Canary Islands, and all around the Mediterranean (van der Linden \& Eikenboom 1992).

Remarks: One of several pyramidellids whose identity is not supported by type material. According to Forbes \& Hanley (1853:255) 'The identity of this shell with the T. indistinctus of Montagu is rather traditional than positive, since the language of the "Testacea Britannica" does not precisely correspond with the characteristics of the present species.' However the interpretation of the species has been stable, at least since the time of Jeffreys (1867). Empty shells might be mistaken for $P$. interstincta, but is most easily distinguished by the lack of a columellar tooth.

\section{Parthenina interstincta (J. Adams, 1797)} Figures 6-11

Turbo interstinctus J. Adams, 1797:66. Neotype assigned and nomenclature discussed by Warén (1991). See Remarks below.

Chemnitzia interstincta (Montagu) - Clark 1855

Odostomia interstincta (Montagu) - Alder 1848; Forbes \& Hanley 1850-51; Jeffreys 1867; Friele 1874; Norman 1879; Jeffreys 1884; Marshall 1900
Odostomia (Parthenia) interstincta (Montagu) - Collin 1880

Parthenia interstincta (Montagu) - G.O. Sars 1878; Collin 1884; Petersen 1888

Pyrgulina (Parthenina) interstincta (Montagu) - Dautzenberg \& Fischer 1925

Parthenina interstincta (Montagu) - Kobelt 1903; Schander et al. 2003

Chrysallida interstincta (J. Adams) - Warén 1991; Peñas et al. 1996; Peñas \& Rolán 1998; Høisæter 2009

Jaminia obtusa T. Brown, 1827:22

Chrysallida obtusa (Brown) - Høisæter 1965; van Aartsen 1977; Høisæter 1989; van der Linden \& Eikenboom 1992; Micali et al. 1993

Chrysallida (Parthenina) obtusa (Brown) - Winckworth 1932; Høisæter 1986; Smith \& Heppell 1991; van Aartsen et al. 2000

Type locality: Bigberry Bay, Devonshire. Great Britain.

Type material: Not found (Warén 1991). Neotype selected by Warén (1991), RAMME 4241.

Material seen: Norway - Skagerrak, 35 spms; Hordaland, 1250 spms; Møre og Romsdal a few shs; Nord-Trøndelag, 13 spms; Nordland, 41 spms; Troms, 1 spm..

Diagnosis: Shell: usually a moderately tall cone with distinct axial costae, ending at lower of two less distinct spiral threads. Further characterized by conspicuous columellar tooth and deep and shouldered suture. No periostracum. Larval shell of type B (Figures 6 to 8).

Soft parts: Foot long, truncated anteriorly and ending in a blunt point, triangular tentacles with terminal pads, yellowbrown to dark brown pigment in a strip on the inside of the tentacle from just before the eyes and to the end of the tentacle groove, eyes fairly small, mentum blunt, short and narrow, pigmented mantle organ a yellow oval blotch with brown margin, white speck at upper right (Figure 9). Operculum: Having a tubelike internal process and without marginal notch (Figure 10).

Biology: A single specimen reported by Cole \& Hancock (1955) from an oyster in a population severely infected by Brachystomia eulimoides. To my knowledge this is the only report on a possible host for $P$. interstincta. The species was found together with six other pyramidellid species on various substrates in Knappensundet, and with five others from a similar habitat at Hillersholmen (both around 60¹6’N, Høisæter 1989). $P$. interstincta was consistently present at the three substrates (Pomatoceros, Modiolus/Pomatoceros, Modiolus/Limaria) studied, but usually in relatively small numbers in comparison to four other species found. The only samples in which it was close to the dominant pyramidellid species was a soft bottom "covered" with living Limaria hians and Modiolus modiolus. It was also found in samples dominated by Pomatoceros triqueter, but always in low numbers. The results support the theory that $P$. interstincta is a species feeding primarily on mollusks but that stray specimens might also try to feed on serpulids (in 
5.
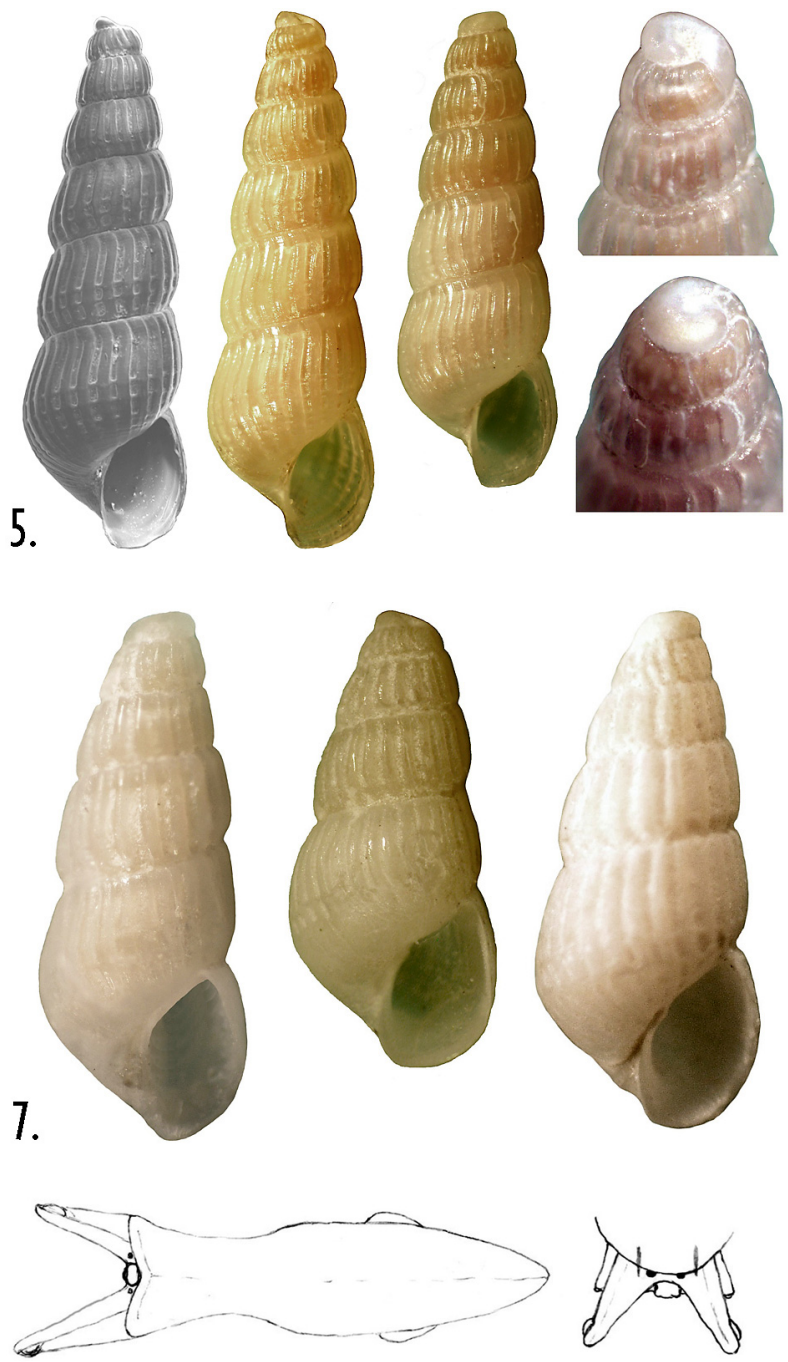

9.

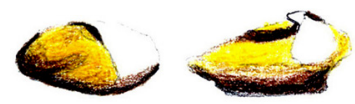

II.

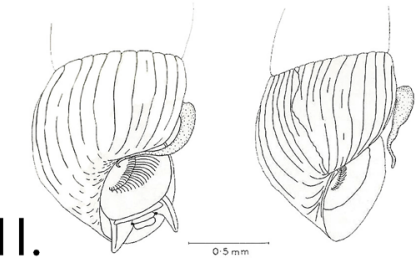

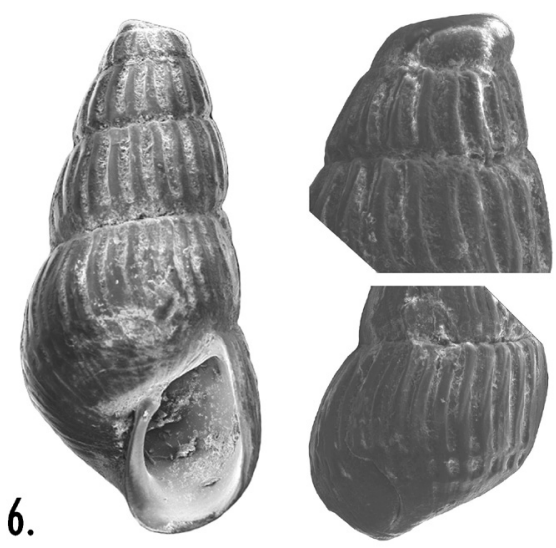

8.
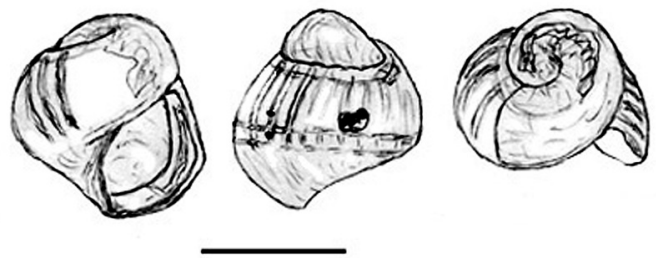

10.

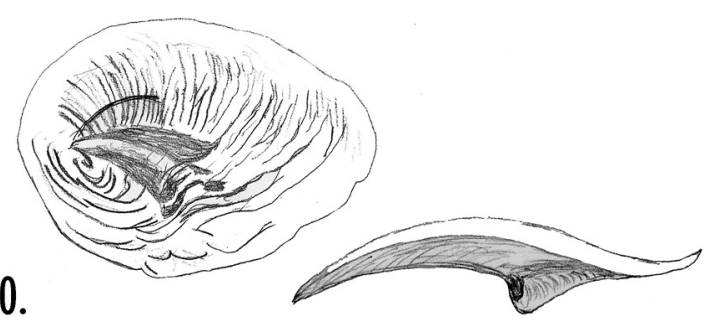

12.

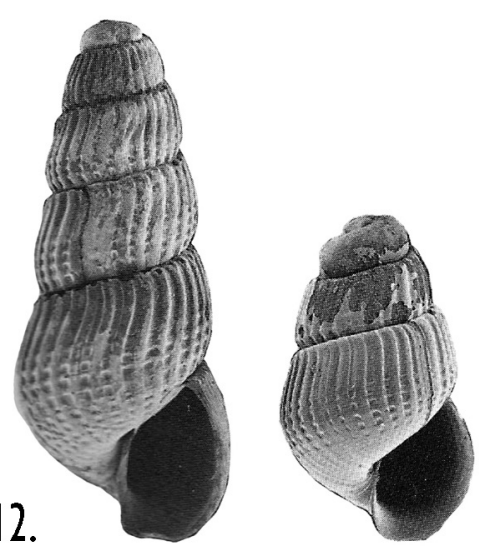

Figure 5. Parthenina indistincta. Two specimens from Vefsnfjorden $65^{\circ} 53^{`} \mathrm{~N}, 12^{\circ} 32^{\prime} \mathrm{E}, 12-15 \mathrm{~m}$, (ZMBN 82368) 3.5 and $3.15 \mathrm{~mm}$. The specimen at left is a SEM photo of the second one from left

Figure 6. Parthenina interstincta. Bukkasundet, Raunefjorden, $60^{\circ} 14^{\prime} \mathrm{N}, 5^{\circ} 12.5^{\prime} \mathrm{E}, 20-4 \mathrm{~m}, 2.0 \mathrm{~mm}$ (ZMBN 82305).

Figure 7. Parthenina interstincta. From left: Vikkilen, Grimstad, 58 $20.1^{\prime} \mathrm{N}, 8^{\circ} 36.3^{\prime} \mathrm{E}, 35 \mathrm{~m}, 2.2 \mathrm{~mm}$; Bukkasundet, Raunefjorden, $60^{\circ} 14^{\prime} \mathrm{N}$,

$5^{\circ} 12.5^{\prime} \mathrm{E}, 20-4 \mathrm{~m}, 2.0 \mathrm{~mm}$ (ZMBN 82305); and Hjertøysund, Bodø, 67ْ $17^{\prime} \mathrm{N}, 4^{\circ} 19.5^{\prime} \mathrm{E}, 30 \mathrm{~m}, 2.15 \mathrm{~mm}$.

Figure 8. Parthenina interstincta, postlarva. Scale bar $=300 \mu \mathrm{m}$.

Figure 9. Parthenina interstincta, head-foot complex and pigmented mantle organ (not to scale).

Figure 10. Parthenina interstincta, operculum, two views.

Figure II. Parthenina interstincta, body whorl and aperture with spermatophore attached (from Høisæter 1965).

Figure 12. Parthenina sarsi. Syntype (left) and specimen from Swedish west coast. Both from Warén (1991). 
many ways a parallel to Brachystomia scalaris).

Høisæter (1965) described spermatophores in this species (as Chrysallida obtusa) (Figure 11). This was the first record for members of this family. Since then Robertson has described spermatophores in several taxa of pyramidellids from the western Atlantic, and used the different forms partly as a basis for genus level taxonomy (Robertson 1966;1967;1978; 1996). A similar view adopted by Hori \& Kuroda (2001).

Distribution: In Norway previously reported from Lofoten (rare) and south along the coast to Oslofjorden (G.O. Sars 1878). In my material common in the Espegrend area (Hordaland, $60^{\circ} 16^{\prime} \mathrm{N}$ ), and sparingly further north, but still not uncommon in the Bodø area around $67.5^{\circ} \mathrm{N}$, (37 specimens in the material from Wikander). A single specimen from the species rich station

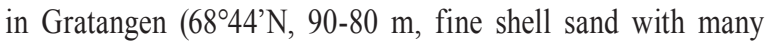
Modiolula shells) is so far the northernmost location. Outside Norway known from Southwestern Iceland and off most coasts of the British Isles, south to the western Mediterranean (Fretter et al. 1986, Warén 1991).

Remarks: Warén (1991) argued that J. Adams' figure of Turbo interstinctus was not more questionable than those of several others that have been accepted as valid. He therefore suggested that J. Adams' name, as used by Montagu (1803) and Jeffreys (1867) should be retained in preference to C. obtusa (a name reintroduced by Winckworth 1932). He designated one of two specimens from Montagu's collection as neotype (figured as Figure 39C in Warén 1991). Van Aartsen et al. (2000) disagreed and presented a long argument for why Turbo interstinctus of J. Adams is not the species that Montagu (1803) called Turbo interstinctus, which is the interpretation of interstinctus adopted by all authors since the time of Jeffreys (1867:153). They first rejected Warén's selection of one of the shells in Montagu's collection labelled Turbo interstinctus as neotype of Turbo interstinctus J. Adams, and then in the next paragraph selected the same shell as neotype of Jaminia obtusa Brown, 1827. I find the reasoning of Warén (1991) convincing, and thus accept $P$. interstincta as the name of this common and widely distributed species. This common, mainly shallow water species is quite variable, as is illustrated by several SEM-photos in Peñas \& Rolán (1998). It is possible in most samples (especially two shallow water, hard bottom stations just southwest of Bodø, $67^{\circ} 16^{\prime} \mathrm{N}, 13 \mathrm{~m}$, and $67^{\circ} 17^{\prime} \mathrm{N}, 50-20 \mathrm{~m}$ ) to distinguish two forms, one with broadly conical shape, evenly rounded whorls, the other rather narrow cylindrical, with more flattened, somewhat 'overhanging' whorls. In good samples of live-caught specimens, both extremes as well as several intermediate specimens are found, however.

\section{Parthenina sarsi (Nordsieck, 1972) Figure 12}

Chrysallida (Besla) sarsi n. sp. - Nordsieck 1972:98

Chrysallida sarsi Nordsieck - Fasseaux 1974; Warén 1991; van der Linden \& Eikenboom 1992; Høisæter 2009

Chrysallida (Besla) sarsi Nordsieck - Smith \& Heppell 1991; van Aartsen \& Menkhorst 1996

Parthenina sarsii (Nordsieck) - Schander et al. 2003

Type material: Two syntypes, SMNH 4110.

Type locality: Charleroi, Belgium (fide Warén 1991).

Material seen: None.

Diagnosis: Shell: According to Warén (1991), it is most reliably distinguished from $P$. indistincta in being proportionally wider and having 13 axial ribs visible rather than $10-11$ visible ribs in P. indistincta. At least six, usually eight or more spiral cords on lower part of body whorl. Soft parts: Not known. Operculum: Not known.

Biology: Not known.

Distribution: Its presence in Norway is based on two shells from the Bergen area mentioned in Warén (1991). Outside Norway he reports 12 specimens from the Koster area in western Sweden. Otherwise it is known from the Atlantic coasts of Europe south to NW Spain (Warén 1991).

Remarks: The species is included here on the authority of Warén (1991). The species was named and described by Nordsieck (1972) based on shells donated by Fasseaux, from La Panne and Colunga, Belgium. A more detailed description and several photographs are given in Fasseaux (1974). The taxon is pictured in van Aartsen (1977), who also regards it as a good species, and says it is found along the Atlantic coast of Europe. In the opinion of Nordsieck (1972) the form was originally described by G.O. Sars (1878) as Parthenia interstincta var. The justification for this identification seems flimsy, and I agree with Warén (1991) that the specimens pictured and described by G.O. Sars are not conspecific with the specimens described and depicted in Fasseaux (1974) and van Aartsen (1977). The specific name is still valid though, even if Nordsieck's identification of G.O. Sars' figure should be due to a misidentification. If the specimens from the Bergen area are indeed correctly identified, this is an extremely rare species in our fauna. I have not seen any shells among my roughly 35000 pyramidellid shells. All shells of ' $C$. decussata' reported from the coast of the Netherlands belong to this species (de Bruyne \& al. 2013).

\section{Parthenina wikanderi n.sp.}

Figures 13-15

LSID: urn:lsid:zoobank.org:act:812C0F6A-88DE-47C1B48C-8F2A64913729

Type material: Holotype ZMBN 99129.

Type locality: Aust-Agder, Grimstad, Fevikkilen, $58^{\circ} 22^{\prime} \mathrm{N}$, $8^{\circ} 40.9^{\prime} \mathrm{E}, 25 \mathrm{~m}$, fine sand.

Etymology: Named after the tireless mollusk-collector and bivalve specialist, Per Bie Wikander from Grimstad, who is singlehandedly responsible for amassing the large material of 
microgastropods from the Skagerrak area, and the majority of the material from Nordland county, permitting me to highlight the contrast between the northern and southern pyramidellid fauna in Norway. All specimens of this new species of Parthenina has been collected and sorted out from bottom material by Per Wikander.

Material seen: Norway: Skagerrak, 6 spms, 2 shs. (Holotype ZMBN 99129).

Description: Shell conical, only slightly convex, apical angle $30^{\circ}-32^{\circ}$. Holotype with four teleoconch whorls, $2.2 \times$ $1.1 \mathrm{~mm}$.Whorls convex, not flatsided. Suture distinct but not canaliculate. Axial ribs straight to slightly curved towards the back, continuing faintly down on the base. The ribs are distinctly wider than the interspaces. Two spiral ribs on body whorl, usually rather obscure, not crossing the axial ribs. Thin, light yellow periostracum, shell underneath chalky white. Protoconch partly intorted, with raised basal edge extending a little outside first teleoconch whorl. Aperture oblong, ovate, spoon-shaped. Umbilicus narrow but distinct. Columellar tooth retracted but fairly strong, sometimes visible in apertural view.

Diagnostic description: Shell: Similar to P. interstincta, but with more evenly rounded, convex whorls, shell wider and more conical, weaker and more rounded axial ribs, and very indistinct spiral ribs. As opposed to P. interstincta, a thin periostracum that flakes off when shell dries. The protoconch is tilted and its base is extending farther outside first teleoconch than that in $P$. interstincta. Columellar tooth weak, but stronger than in P. interstincta. Soft parts: Not known. Operculum: Not known.

Distribution: So far only found on the Norwegian Skagerrak coast (ZMBN 99129, G 28-71 (2), G 52-71 (2 sh), S 17-87; S 8-88, and S 37-88).

Remarks: Quite a number of species of Chrysallida s.l. have been described from the southern part of the Northeast Atlantic and the Mediterranean, but none of those illustrated in van der Linden \& Eikenboom 1992; Peñas et al. 1996; Peñas \& Rolán 1998; van Aartsen et al. 2000, or Cachia et al. 2001 seem to fit. Those with a similar sculpture, are all narrower and less conical. The new species might be a variety of the variable $P$. interstincta, but the specimens of this latter species from the Skagerrak I have seen are all much narrower, more cylindrical. The periostracum also seems to be specific for this new species. A character of possible taxonomic importance is that the sculpture is often partly eroded and faint. The axial ribs are less sharply cut out than in P. interstincta, and are easily 'destroyed' when the shell is handled (Figure 14).

\section{Spiralinella Chaster, 1901}

Type species by original designation, Turbo spiralis Montagu, 1803; Britain

Pyramidellids with small $(<3.5 \mathrm{~mm}$ long), elongate-ovate to truncated, conical, solid shells, of not more than six whorls. Sculpture consisting of axial ribs, and spiral sculpture, as raised costae on base. Columellar fold present, though sometimes rather retracted. Protoconch medium-sized to small, intorted. Operculum (Figure 20) oligogyrous, thin, with no indentation for the columellar fold. Yellowish, internal process of moderate thickness, gradually decreasing in thickness towards the opercular edges from the walls around a central, slightly arched groove. Tentacles triangular with tentacular pads at their tip. Pigmented mantle organ irregularly oval to circular consisting of yellow and brown patches.

Partulida Schaufuss, 1869 has been used as name for this group (e.g. Iredale 1917, Fretter et al. 1986, Graham 1988, Høisæter 1989, Smith \& Heppell 1991, van Aartsen et al. 2000). This is the oldest name with Turbo spiralis designated as type species (Iredale 1917). However, as Corgan (1973) pointed out, Turbo spiralis is not available as it was not mentioned in Schaufuss (1869). The next oldest name is Spiralinella Chaster, 1901, which is adopted by e.g. Schander et al. (2003).

\section{Spiralinella spiralis (Montagu, 1803)}

Figures 16-20

Turbo spiralis Montagu, 1803:323 (not Poiret, 1801)

Turbonilla spiralis (Montagu) - Lovén 1846a, b

Chemnitzia spiralis (Montagu) - Clark 1855

Odostomia spiralis (Montagu) - Alder 1848; Forbes \& Hanley 1850-51; M. Sars 1859; Jeffreys 1867; Jeffreys 1870; M. Sars 1870; Friele 1874; A. Brown 1875; Norman 1879; Jeffreys 1884; Marshall 1900

Odostomia (Parthenia) spiralis (Montagu) - Collin 1880; Spärck \& Thorson 1933

Parthenia spiralis (Montagu) - G.O. Sars 1878; Collin 1884; Schneider 1886; Petersen 1888; Norman 1892; Friele \& Grieg 1901

Parthenina spiralis (Montagu) - Kobelt 1903

Pyrgulina spiralis (Montagu) - Norman 1902

Pyrgulina (Spiralinella) spiralis (Montagu) - Dautzenberg \& Fischer 1925

Chrysallida spiralis (Montagu) - van Aartsen 1977; Warén 1991; van der Linden \& Eikenboom 1992

Chrysallida (Partulida) spiralis (Montagu) - Winckworth 1932; Høisæter 1986

Partulida spiralis (Montagu) - Iredale 1917; Fretter et al. 1986; Graham 1988; Høisæter 1989; Smith \& Heppell 1991

Voluta pellucida Dillwyn, 1817:508 (new name for Turbo spiralis Montagu, not Gmelin)

Chrysallida pellucida (Dillwyn) - van Aartsen \& GianuzziSavelli 1991; Schander 1995; Peñas et al. 1996; Høisæter 2009

Chrysallida (Partulida) pellucida (Dillwyn) - van Aartsen et al. 2000

Spiralinella pellucida (Dillwyn) - Schander et al. 2003 

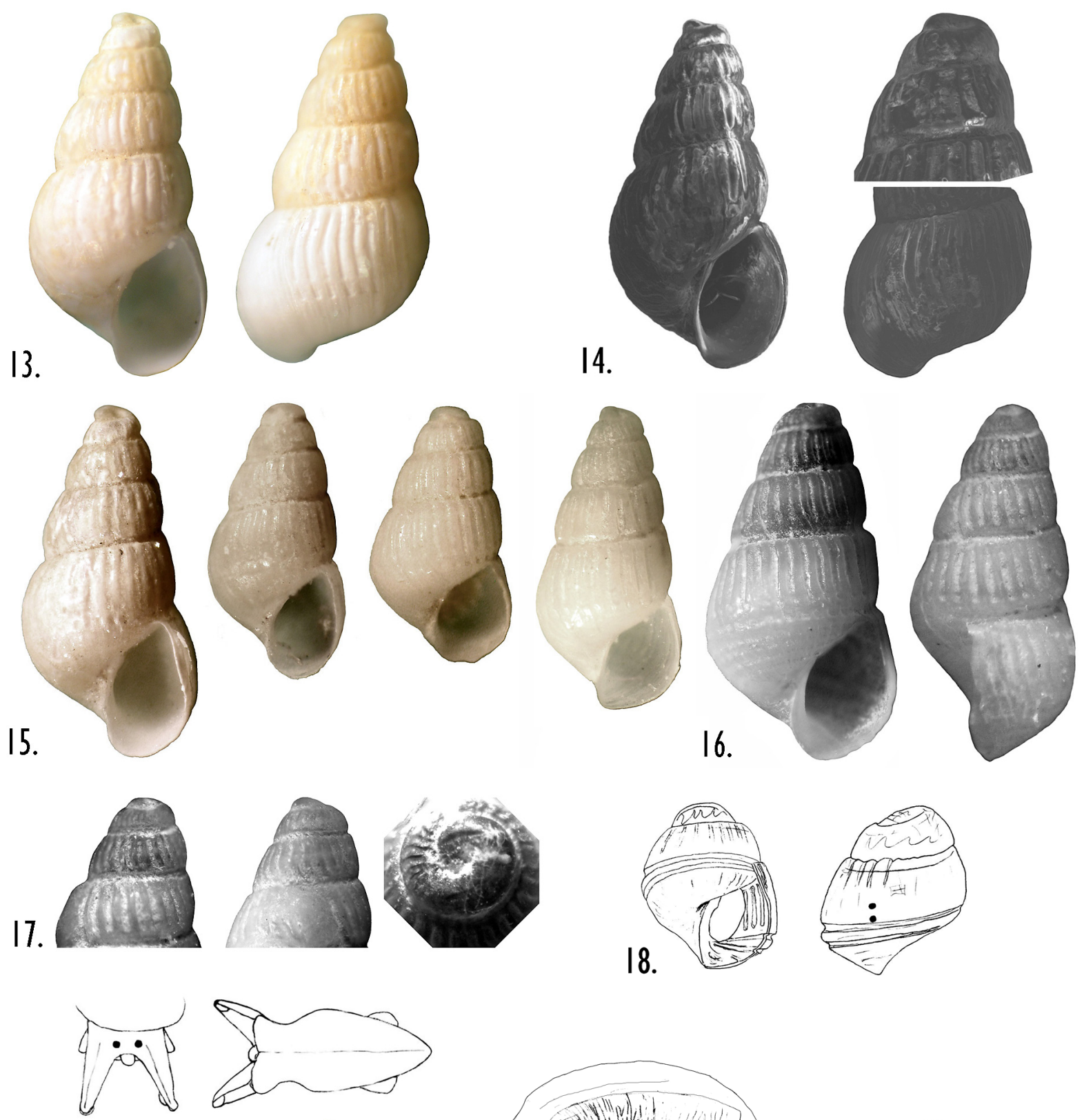

19.
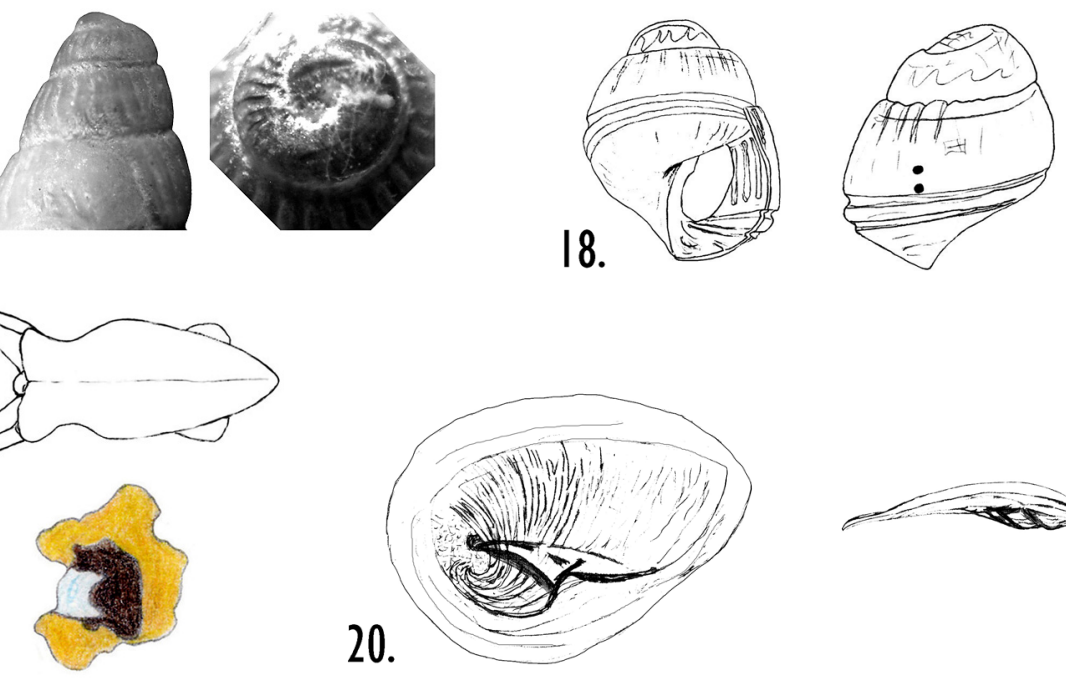

18.
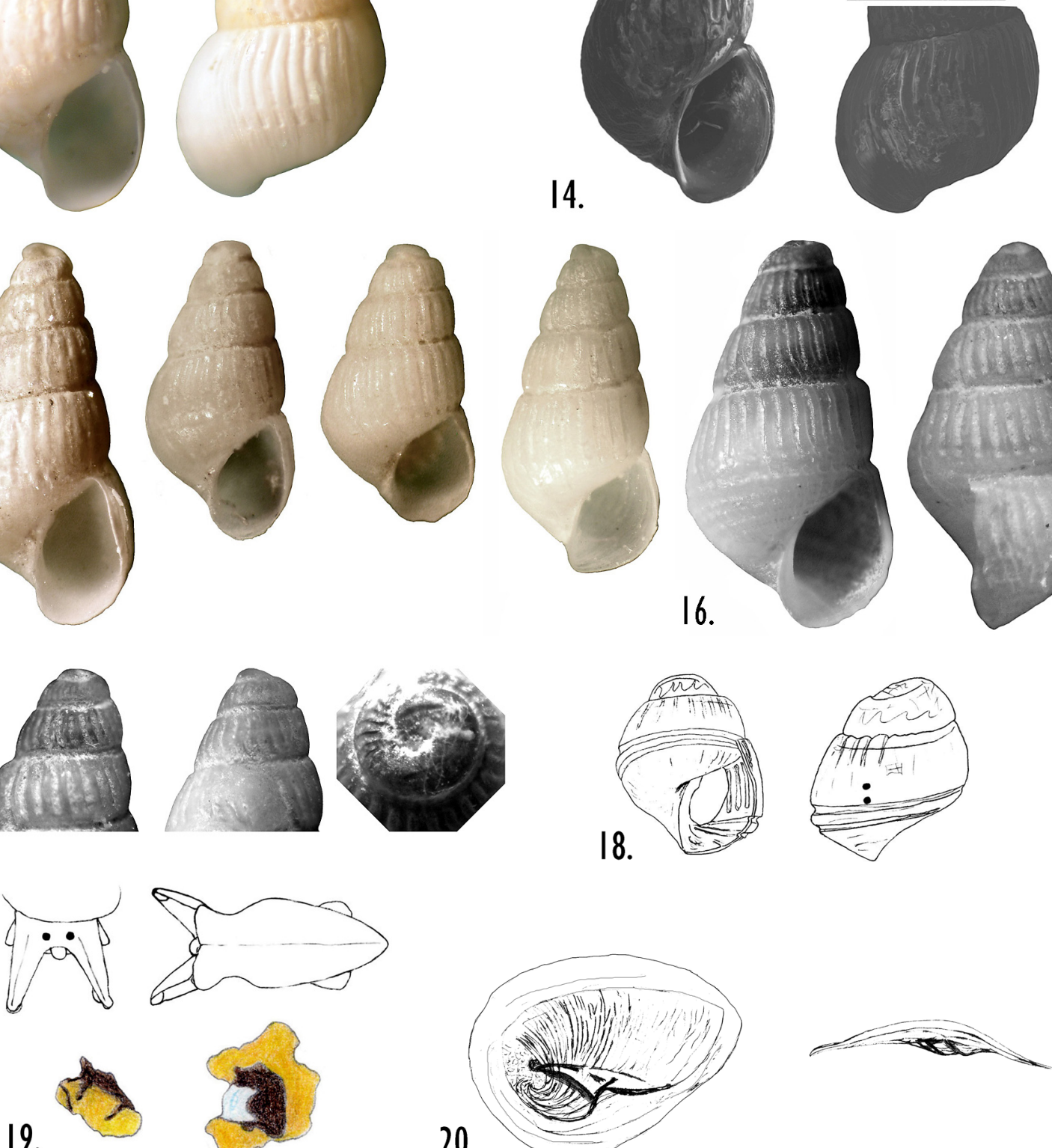

20.

Figure 13. Parthenina wikanderi n.sp., holotype, Fevikkilen, Grimstad, 58²2’N, 840.9’E, 25 m, 2.2 mm (ZMBN 99129)

Figure I4. Parthenina wikanderi n.sp., holotype, Fevikkilen, Grimstad, 58²2’N, 840.9’E, 25 m, 2.2 mm (ZMBN 99129). The top whorls at right from $\mathrm{S} 37-88$. SEM.

Figure 15. Comparison between Parthenina wikanderi n.sp. (two specimens at left) and P. interstincta (two at right). To scale, the holotype at left is $2.2 \mathrm{~mm}$ long (ZMBN 99129, S 37-88, ZMBN 82355, ZMBN 82305).

Figure 16. Spiralinella spiralis, Hillersholmen, Raunefjorden, 60¹7.8' N, 5¹1.2’ E, 6-8 m (ZMBN 82405) (left), Hjertøysund, Bodø, 67¹7'

$\mathrm{N}, 14^{\circ} 20^{\prime} \mathrm{E}, 40-30 \mathrm{~m}$, both $2.2 \mathrm{~mm}$ (N 82-76).

Figure 17. Spiralinella spiralis, Protoconchs of specimens in Figure 15, three orientations.

Figure 18. Spiralinella spiralis, juvenile, three orientations.

Figure 19. Spiralinella spiralis, head-foot complex and pigmented mantle organ (not to scale).

Figure 20. Spiralinella spiralis, operculum, two views. Scale bar $=200 \mu \mathrm{m}$. 
Type material: Three syntypes, RAMME no. 4240, three syntypes BMNH (fide Warén 1991).

Type locality: Salcombe Bay, Devonshire on the southern British coast (fide Warén 1991).

Material seen: Norway - Skagerrak, 30 spms; Hordaland, 3600 spms; Møre og Romsdal a few shs; Nord-Trøndelag, a few shs; Nordland, 67 spms.

Diagnosis: Shell: Easily recognized on its distinctive sculpture, with strong flatsided axial ribs on upper part of each whorl and equally strong spiral ribs on the base of the last whorl. Soft parts: Foot rather broad and short, truncated and a little concave anteriorly, narrowed a little behind the front, widening further behind and ending in a blunt point. Triangular tentacles with tentacular pads, eyes fairly small, mentum short and narrow with a rounded tip (Figure 19). Pigmented mantle organ (Figure 19) an irregular blotch with yellow and brown parts. Operculum: Have a channeled internal process and without a distinct marginal notch (Figure 20).

Biology: According to Fretter et al. (1986) mostly associated with tubes of sedentary polychaetes, colonies of Sabellaria (Fretter 1949) and Pomatoceros (Ankel 1959). In each of 12 samples from Hillersholmen in which the primary substrate was aggregations of Pomatoceros, hundreds of specimens was found. In this locality $S$. spiralis was consistently at least three times as common as $P$. interstincta. In the locality at Knappensundet most common on Modiolus-Limaria substrate. At this locality present in many samples with very little Pomatoceros present (Høisæter 1989). S. spiralis was most abundant (50 specimens) in a 1/2x1/2 m sample from $11 \mathrm{~m}$, completely dominated by Limaria hians and living specimens as well as empty shells of Modiolus. In the field notes it is noted that Pomatoceros was present but very sparingly. In this and a neighbouring sample (also with very little Pomatoceros), six species of pyramidellids occurred in almost equal numbers.

Distribution: This species is one of the few north-European pyramidellids recognizable at a glance, and therefore with more reliable records than most. In Norway it has been reported from the whole coast, east Finnmark included (Verkrüzen 1875, G.O. Sars 1878, Norman 1902). In my material one of the most abundant pyramidellids, with altogether more than 3600 specimens from the Espegrend area. On the coast north of Stadt 70 specimens (most of them from Nordland county, leg. Per Wikander), and more than 220 shells. The northernmost specimen is from Kvæfjorden in southern Troms $\left(68^{\circ} 50^{\prime} \mathrm{N}\right.$, $30 \mathrm{~m}$, rocky bottom with lots of red algae (Ptilota plumosa)). The shells were primarily from Nordland south of Bodø and from Nord-Trøndelag. Outside Norway known from the Faroes (Schander 1995), south-western Iceland (Warén 1991), the British Isles, south to the western Mediterranean, and sparingly at the Canary Islands.

Remarks: Turbo spiralis Montagu, 1803 is preoccupied by Turbo spiralis Poiret, 1801 and should therefore be replaced by Voluta pellucida Dillwyn, 1817 (van Aartsen \& GianuzziSavelli 1991). Their justifications for this name change are not convincing, however. The main reason is the 50 -year rule as expressed in ICZN: "Prevailing usage must be maintained when the following conditions are both met. 23.9.1.1 - the senior synonym or homonym has not been used as a valid name after 1899. 23.9.1.2 - the junior synonym or homonym has been used for a particular taxon, as its presumed valid name, in at least 25 works, published by at least 10 authors in the immediately preceding 50 years, and encompassing a span of not less than 10 years. Both of these 'rules' are amply met for Turbo spiralis. Van der Linden \& Eikenboom (1992) prefer the well known name, $C$. spiralis for the same reasons as given above. $C$. pellucida has been adopted by CLEMAM (2014) however, but else (to my knowledge) only van Aartsen \& Gianuzzi-Savelli (1991), Schander (1995), van Aartsen et al. (2000), and Høisæter (2009) have used pellucida for this species.

My reason for excluding this species from Parthenina is the indication from the $16 \mathrm{~S}$ analysis in Schander et al. (2003) that $S$. spiralis is belonging to another clade than three members of Parthenina.

\section{Chrysallida Carpenter, 1856 s.l.}

This name is used for five species not easily included in Parthenina or any other described genus. I provisionally include 'C.' bjoernssoni, ' $C$.' brattstroemi, 'C.' eximia, and ' $C$.' hoeisaeteri in one genus-group taxon, and ' $C$.' subslustris in another.

Key to the species of Chrysallida s.l., based on shell morphology

1a. No spiral sculpture Chrysallida sublustris

1b. Shell with three spiral cords on body whorl $\ldots 2$

2a. Protoconch distinctly keeled..... Chrysallida bjoernssoni

2b. Protoconch different.......................................................

3a. Shell small, almost globular, whorls shouldered Chrysallida brattstroemi

3b. Shell elongated, narrow, convex whorls ..Chrysallida eximia

3c. Shell with prosocline axial ribs, protoconch perfectly smooth Chrysallida hoeisaeteri

\section{'Chrysallida' bjoernssoni (Warén, 1991)} Figure 21

Chrysallida bjoernssoni sp.n. - Warén, 1991:100

Chrysallida bjoernssoni Warén - Høisæter 2009

Chrysallida (Trabecula) kronenbergi - van Aartsen et al., 2000:41

Type material: Holotype $(1.52 \mathrm{~mm})$ and nine paratypes, SMNH 4092 and 4093. 
Type locality: Southeastern Iceland, Skeidarardypet, c. $200 \mathrm{~m}$

Material seen: Norway - Norwegian Trench $\left(61^{\circ} 30^{\prime} \mathrm{N}\right.$, 0200'E, $311 \mathrm{~m}$ ), 1 sh; Troms, 17 shs.

Diagnosis: Shell: The most diagnostic character is the keeled, funnelshaped protoconch (Figure 21 right), and Figure 33E in Warén (1991). Soft parts: Not known. Operculum: Not known.

Biology: Unknown.

Distribution: From Norway, only the material listed above is known. Three samples from the Andfjorden area, eight and two fairly well preserved shells from two Lophelia reef samples, and seven from a sample from Bleiksdjupet northwest of Andøya, $\left(69^{\circ} 25^{\prime} \mathrm{N}, 200-700 \mathrm{~m}\right.$, stones and clay). In addition a single shell from the western 'slope' of the Norwegian Trench $\left(83.11 .17 .5,61^{\circ} 30^{\prime} \mathrm{N}, 02^{\circ} 00^{\prime} \mathrm{E}, 311 \mathrm{~m}\right)$. All of the Norwegian samples are from depths around or a little below $300 \mathrm{~m}$. Only empty shells found, and thus not verified that it is still living here. Outside Norway, 20 shells on which the description was based from $200 \mathrm{~m}$ in south-eastern Iceland. The only known additional material is two shells from $156 \mathrm{~m}$ in eastern Greenland (Warén 1991). With the material from Norwegian waters listed above, the distribution limit is moved considerably eastwards. See also Remarks below.

Remarks: In Warén (1991) the species is explicitely named for the Icelandic collector Johannes Björnsson, and spelled $C$. bjoernssoni. However the name of the collector is misspelled "Johannes Björnson" in the same sentence, the species name is spelled "bjoernsoni" in a figure caption. Chrysallida (Trabecula) kronenbergi van Aartsen et al., 2000 from deep water near the Azores, in many ways resemble $C$. bjoernssoni, but (according to van Aartsen et al.) lacks the distinct spirals that the latter species have. The SEM photograph accompanying their description clearly shows three spiral cords not crossing the axial ribs, and is almost indistinguishable from the SEM photo of C. bjoernssoni in Warén (1991) and the specimen at right in Figure 21 above. Van Aartsen et al. (2000) place their new species in the subgenus Trabecula, based on Chrysallida jeffreysiana (Monterosato, 1884). I do not agree as, judging from their SEM-photo, C. kronenbergi and $C$. jeffreysiana are very different morphologically. If C. kronenbergi is conspecific with $C$. bjoernssoni, then the species has a very wide distribution, from eastern Greenland, via Iceland and northern Norway, the Norwegian Trench to the bathyal (c. $600 \mathrm{~m})$ near the Azores.

\section{Chrysallida brattstroemi (Warén, 1991)} Figure 22

Chrysallida brattstroemi sp.n. - Warén, 1991:100

Chrysallida brattstroemi Warén - Micali et al. 1993; Peñas et al. 1996; Høisæter 2009
Type material: Holotype $(1.15 \mathrm{~mm})$ and 20 paratypes, SMNH 4094 and 4095.

Type locality: Skagerrak, $58^{\circ} 54^{\prime} \mathrm{N}, 10^{\circ} 33^{\prime} \mathrm{E}, 200-220 \mathrm{~m}$, mud with arenaceous foraminifera.

Material seen: Norway - Hordaland, 12 spms; NordTrøndelag, $1 \mathrm{spm}$ and 13 shs; Nordland, 3 shs.

Diagnosis: Shell: small (max. $1.25 \mathrm{~mm}$ ), colourless, with few whorls and strong axial ribs continuing down to the base and into the umbilicus, three much weaker spiral cords not crossing the axial ribs. Protoconch depressed and pertfectly smooth. Soft parts: Not known. Operculum: Not known.

Biology: Not known.

Distribution: This species was described from 21 specimens from a sample taken just south of Færder in the Skagerrak $\left(58^{\circ} 54^{\prime} \mathrm{N}, 10^{\circ} 33^{\prime} \mathrm{E}, 200-220 \mathrm{~m}\right)$. Warén reported in addition five specimens from the shelf outside Korsfjorden $\left(60^{\circ} 08^{\prime} \mathrm{N}\right.$, 250 to $380 \mathrm{~m}$ ) and a single shell from Trondheimsfjorden. In my material 13 specimens and 16 shells. Three shells from Tomfjorden $\left(66^{\circ} 12^{\prime} \mathrm{N}, 380-300 \mathrm{~m}\right.$, mixed bottom), one specimen and one shell from outer part of Bindalsfjorden, $\left(65^{\circ} 12^{\prime} \mathrm{N}, 12^{\circ} 10^{\prime} \mathrm{E}, 510-460 \mathrm{~m}\right.$, soft bottom), and four samples from Risvær-fjorden $\left(65^{\circ} \mathrm{N}, 11^{\circ} 29^{\prime} \mathrm{E}, 100-200 \mathrm{~m}\right.$, shells only). Finally 12 well preserved specimens from the shelf outside Korsfjorden $\left(60^{\circ} 07.5^{\prime} \mathrm{N}, 4^{\circ} 51^{\prime} \mathrm{E}, 317-315 \mathrm{~m}\right.$, silty sand with lots of foraminiferans; coll. and leg. A. Warén). Outside Norway known from the Italian Lower Pleistocene and as Recent from the western Mediterranean (Warén 1991, Micali et al. 1993, Peñas et al. 1996).

Remarks: This species seems to have a more southern distribution than $C$. eximia (not known south of western Scotland), C. hoeisaeteri and C. bjoernssoni. These also have a narrower and longer shell. I provisionally place it in a group together with these species, although the relationship might be to some more southern, deep water species, e.g. C. stefanisi (Jeffreys, 1869).

\section{Chrysallida eximia (Jeffreys, 1849)}

Figure 23

Rissoa eximia Jeffreys, 1849:299

Chemnitzia eximia (Jeffreys) - Forbes \& Hanley 1853

Odostomia eximia (Jeffreys) - Jeffreys 1867; Jeffreys 1870; Friele 1874; Norman 1879; Jeffreys 1884; Marshall 1900

Odostomia (Parthenia) eximia (Jeffreys) - Spärck \& Thorson 1933

Parthenia eximia (Jeffreys) - G.O. Sars 1878; Friele \& Grieg 1901

Parthenia eximia var. elongata (Verkrüzen) - G.O. Sars 1878; Schneider 1886

Pyrgulina eximia (Jeffreys) - Norman 1902

Parthenina eximia (Jeffreys) - Kobelt 1903

Chemnitzia Barleei Clark, 1851:129 - Clark 1855

Chrysallida eximia (Jeffreys) - van Aartsen 1977; Warén 1980, 
1991; Fretter et al. 1986; Smith \& Heppell 1991; van der Linden \& Eikenboom 1992; Schander 1995; Høisæter 2009 Chrysallida (Parthenina) eximia (Jeffreys) - Winckworth 1932; Høisæter 1986

Type material: 25 syntypes, USNM 131880.

Type locality: Off Lerwick, Shetland.

Material seen: Norway - Skagerrak, 1 sh; Hordaland, 27 spms; Norwegian Trench (83.11.17.5, 61º'N, 311 m), 4 spms; Møre og Romsdal 6 spms, 10 shs; Nord-Trøndelag, 7 spms, at least 14 shs; Nordland, 5 spms, at least 20 shs; Troms 1 sh.

Diagnosis: Shell: Strongly convex whorls with orthocline axial ribs and three strong spiral cords. Protoconch high with a coarse surface. Soft parts: Pigmented mantle organ (Figure 23, based on a single observation) an orange oval with a white circle embedded. Operculum: Not studied.

Biology: Not known.

Distribution: In Norway found along the whole coast, including east Finnmark (G.O. Sars 1878, Norman 1902), although only occasionally north of Lofoten. Although reported from both Oslofjorden and Skagerrak by G.O. Sars (1878), I found no specimens in my material from Skagerrak. North of Hordaland, surprisingly few specimens found compared to the hundreds (at least 250) of empty shells. Outside Norway only reported from southeastern Greenland, Iceland, the Faroes, Swedish west coast, east of Shetland, western Scotland and a single shell from west of Ireland, $764 \mathrm{~m}$ (Jeffreys 1867, Fretter et al. 1986, Warén 1991, Schander 1995).

Remarks: See below under $C$. hoeisaeteri.

\section{Chrysallida hoeisaeteri (Warén, 1991) Figure 24}

Chrysallida hoeisaeteri sp.n. - Warén 1991:98

Chrysallida hoeisaeteri Warén - Høisæter 2009

Type material: Holotype (2.00 mm) SMNH 4091

Type locality: Southwestern Norway, off Korsfjorden $60^{\circ} 08^{\prime} \mathrm{N}, 04^{\circ} 56^{\prime} \mathrm{E}, 270-250 \mathrm{~m}$.

Material seen: Norway - Nordland 2 spms; Troms, 8 shs.

Diagnosis: Shell: Strongly convex whorls with prosocline axial ribs and three spiral cords. Protoconch high with smooth surface, well defined transition from protoconch to teleoconch. Soft parts: Not known. Operculum: Not known.

Biology: Not known.

Distribution: Norway, known from a specimen from the shelf outside Korsfjorden (holotype). In my material three samples with respectively six, three and five somewhat worn shells might belong to this species. These are from the same three stations in the outer part of Andfjorden (Bleiksdjupet and the Steinavær coral reef) as C. bjoernssoni is reported from above. (The two specimens from Nordland referred to above are questionable). Outside Norway only known from a few specimens from northern Iceland, and some shells from southeastern Iceland and eastern Greenland (Warén 1991).

Remarks: Belongs to a species complex together with C. eximia and C. bjoernssoni. Differs from C. eximia by fewer, stronger and more prosocline axial ribs, and from $C$. bjoernssoni by the likewise prosocline axial ribs, a more conical shape, and a protoconch without keel and well defined transition to teleoconch (Figure 24 right).

\section{Chrysallida sublustris (Friele, 1886) Figures 25-26}

\section{Odostomia sublustris Friele, 1886:29}

Odostomia sublustris Friele - Friele \& Grieg 1901; Grieg 1915; Høisæter 1986

Chrysallida (Odostomella) sublustris (Friele) - Nordsieck 1972 Chrysallida sublustris (Friele) - Warén 1991; Micali et al. 1993; Schander 1995; Høisæter 2009

Turbonilla (s.str.) sublustris (Friele) - Kobelt 1903

Type material: Several syntypes ZMBN 21612, 21613, 21614 (see Micali et al. 1993).

Type locality: Norwegian continental slope, off NW Norway, $640-1187 \mathrm{~m}$.

Material seen: Norway - Lower slope off Norway, between $62^{\circ}$ and $63^{\circ} \mathrm{N}, 9$ spms, 1 shell.

Diagnosis: Shell: Semitransparent, glossy of a greenishyellow hue. Cyrtoconoid to conical, with distinctly convex whorls. Maximum shell length $3.1 \mathrm{~mm}$. Growth lines nearly orthocline. Sculpture consisting of shallow and wavy axial ribs fading away on the lower part of the body whorl. No spiral sculpture. Columellar tooth is barely visible. Protoconch large, smooth and glossy. Soft parts: Eyes black, fairly large with distance between double the diameter. Operculum: Not studied.

\section{Biology: Not known.}

Distribution: Norwegian Sea and lower slope off Norway. Until recently recorded only a few times. Friele (1886) reported it from three stations $66^{\circ} 640 \mathrm{~m}, 68^{\circ} 1150 \mathrm{~m}$, and $69^{\circ} 1187 \mathrm{~m}$. Grieg (1915) reported a single specimen from the slope outside 'Tampen' (62¹5'N, 0¹5'E, $800 \mathrm{~m})$. Warén (1991) added two shells from south of Jan Mayen and one shell from northeastern Iceland. Warén (1993) reported it from two stations on the slope north of the Faroes, while Schander (1995) reported it from seven BIOICE stations in the Norwegian Sea north and east of Iceland. In my material nine specimens from five stations, all on the slope at negative temperatures, $62^{\circ} 31.5^{\prime} \mathrm{N}, 701 \mathrm{~m}$, one specimen; $62^{\circ} 12^{\prime} \mathrm{N}, 708 \mathrm{~m}$, three specimens; $63^{\circ} 10^{\prime} \mathrm{N}, 830 \mathrm{~m}$, one specimen; and $63^{\circ} 13^{\prime} \mathrm{N}, 1003 \mathrm{~m}$, three specimens. So far only reported from negative temperature water masses from the continental slopes around the Norwegian Sea (see Høisæter 2010).

Remarks: This species is little known, and only occasionally 

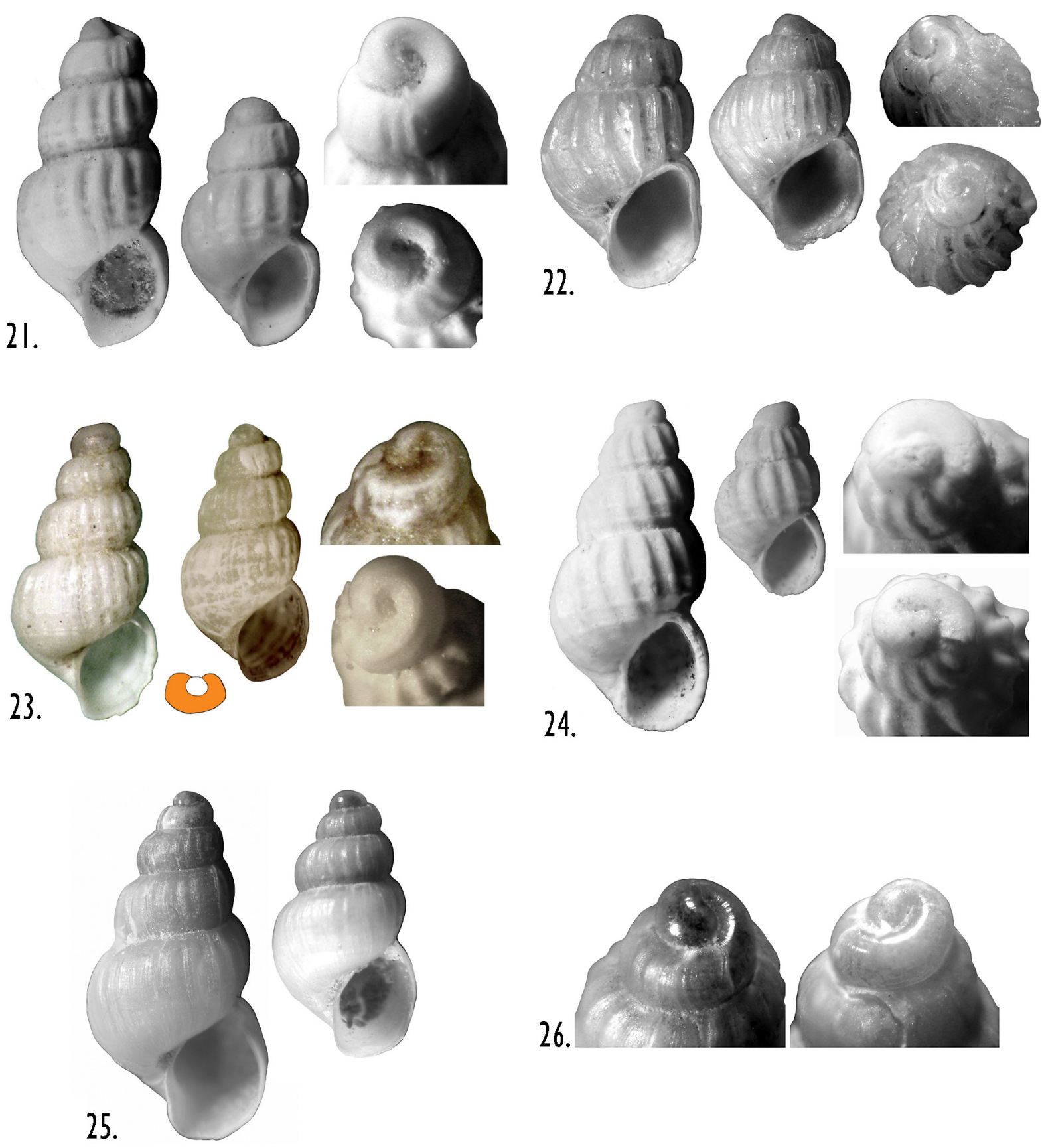

Figure 2l. Chrysallida bjoernssoni, Bleiksdjupet, NW of Andenes, $69^{\circ} 25^{\prime} \mathrm{N}, 15^{\circ} 47^{\prime} \mathrm{E}, 700-200 \mathrm{~m}, 1.7 \mathrm{~mm}$ (ZMBN 82384) (left) and Norwegian Trench, $62^{\circ} 30^{\prime} \mathrm{N}, 02^{\circ} 00^{\prime} \mathrm{E}, 311 \mathrm{~m}, 1.25 \mathrm{~mm}$ (ZMBN 82385).

Figure 22. Chrysallida brattstroemi. Outer Korsfjorden $60^{\circ} 07.5^{\prime} \mathrm{N}, 4^{\circ} 51^{\prime} \mathrm{E}, 317-315 \mathrm{~m}, 1.25$ and $1.1 \mathrm{~mm}$ (ZMBN 82285).

Figure 23. Chrysallida eximia, Fugløyfjorden, $67^{\circ} 01^{\prime} \mathrm{N}, 13^{\circ} 50.5^{\prime} \mathrm{E}, 70-50 \mathrm{~m}, 1.70 \mathrm{~mm}$ (ZMBN 82491) (left), and Raunefjorden,

Liholmsrennen, $60^{\circ} 18^{\prime} \mathrm{N}, 5^{\circ} 10^{\prime} \mathrm{E}, 70-55 \mathrm{~m}, 1.35 \mathrm{~mm}$ (ZMBN 82455. Pigmented mantle organ at bottom centre (not to scale).

Figure 24. Chrysallida hoeisaeteri. Two specimens from Andfjorden, Ørja, 69¹3.9’ N, 16 $40.9^{\prime} \mathrm{E}, 2.00$ and $1.25 \mathrm{~mm}$ respectively (ZMBN 82379).

Figure 25. Chrysallida sublustris. Lower slope, $63^{\circ} 13^{\prime} \mathrm{N}, 03^{\circ} 07^{\prime} \mathrm{E}, 1003 \mathrm{~m}, 3.05 \mathrm{~mm}(82.08 .23 .1)$, and upper slope, $62^{\circ} 12^{`} \mathrm{~N}, 00^{\circ} 00^{\prime} \mathrm{E}, 7^{2} 08$ m, $2.30 \mathrm{~mm}(83.06 .02 .1)$.

Figure 26. Chrysallida sublustris, protoconchs of two specimens from same localities as in Figure 23. 
mentioned in the literature. It is apparently not closely related to any of the other pyramidellids from our region. Three different generic designations have been proposed for it, none of them satisfying. The original designation to Odostomia by Friele was correct enough according to the system used by him, but the attempts to transfer it to Turbonilla (by Kobelt 1903) or to Chrysallida (or Odostomella, Nordsieck 1972) lack factual support. The species' closest congeners must probably be sought among species known from Arctic waters, maybe Menestho or Aartsenia.

\section{Brachystomia Monterosato, 1884}

Type species, by subsequent designation: Odostomia rissoides Hanley, 1844 (= B. scalaris MacGillivray, 1843); designated by Crosse (1885); Britain.

Pyramidellids with small $(<5 \mathrm{~mm}$ long), elongate-ovate to truncated, conical, solid shells, of not more than six whorls. No macroscopic sculpture. Columellar tooth present, though sometimes rather retracted. Protoconch medium-sized to small, intorted. Operculum (Figure 33) oligogyrous, thin, without a distinct indentation for the columellar tooth. Yellowish, internal process of moderate thickness, gradually decreasing in thickness towards the opercular edges. Tentacles triangular with tentacular pads at their tip. Pigmented mantle organ irregularly oval to circular consisting of yellow and brown patches.

In our waters four species may be included in this 'genus', but shell characters alone are not sufficient for verifying this. I have seen living material only of $B$. scalaris. Since this is the type species, it may be used for describing the soft parts, and how this genus differs from Odostomia s.s. Most authors have regarded Brachystomia as a subgroup of Odostomia, but Fretter et al. (1986), based on the submerged protoconch and lack of obvious shell sculpture singled out $O$. scalaris, $O$. eulimoides, O. carrozzai (as O. albella) and O. lukisi as British members of Brachystomia. O. lukisi is definitely not closely related to the former three, and should be allocated its own new genus (see below). Schander (1995) includes O. eulimoides as well as $O$. carrozzai in Brachystomia, but without any explanation. Schander et al. (2003) operates with a clade 'Brachystomia' as separate from Odostomia, but did not include the type species in their analysis. The two exotic species included may or may not be closely related to our northeast Atlantic species. They did however include one of our four species, Odostomia angusta, in their analysis, and found this to belong in a clade together with four species of Odostomia s.s. Their two species of 'Brachystomia' were grouped with species of Parthenina, Liostomia, Jordaniella in a clade named Liostomini. This may be an indication that Odostomia angusta is not a member of Brachystomia after all, or that the specimen (from Vigo in northern Spain) sequenced by Schander et al. was misidentified.
Key to the species of Brachystomia, based on shell morphology

1a. Whorls tumid, subsutural shelf distinct Brachystomia scalaris

1b. Whorls less tumid, subsutural shelf inconspicuous ........2

2a. Body whorl occupying at least two thirds of total ............. Brachystomia eulimoides

2b. Body whorl less dominating ....... . .3

3a. Height of aperture less than $40 \%$ of shell height ...Brachystomia carrozzai

3b. Height of aperture more than $45 \%$ of shell height .. Brachystomia angusta

\section{Brachystomia angusta (Jeffreys, 1867) Figure 27}

Odostomia pallida var angusta Jefffeys, 1867:125

Odostomia pallida var angusta Jeffreys - Marshall 1899b; Warén 1980

Odostomia angusta Jeffreys - van Aartsen 1987; Smith \& Heppell 1991; Peñas et al. 1996; Schander et al. 2003; Høisæter 2009

Type material: Syntype, Bantry Bay, USNM 132101 (Warén 1980: 37, pl. 6, Figure 18 (not 22 as stated in the caption, van Aartsen 1987).

Type locality: Not designated (Warén 1980)

Material seen: Norway - Skagerrak, 5 spms, 2 shs; Møre og Romsdal 2 spms; Nord-Trøndelag, 6 shs; Nordland, 1 sh. All identifications are tentative.

Diagnosis: Shell: Similar to B. eulimoides, but narrower, and with orthocline growth lines. The body whorl occupies a proportionally smaller part of the shell than in B. eulimoides. From B. scalaris it is most easily distinguished by its less turreted form, with shallower sutures, especially the first few postnuclear whorls. Max. length given as $3.2 \mathrm{~mm}$ in Peñas et al. (1996). Soft parts: Not known. Operculum: Not known.

Biology: Not known.

Distribution: This species (or variety) has so far not been reported from Norwegian waters, but the localities listed by Jeffreys (1867:125, from Guernsey to Shetland), makes it likely that it should also be found in our waters. I have tentatively identified two specimens and ten shells as this species, all taken between $62^{\circ} 28^{\prime} \mathrm{N}$ and $67^{\circ} 15^{\prime} \mathrm{N}$. Outside Norway it is only known from the localities mentioned by Jeffreys (1867) and Marshall (1899b) ("several places from Guernsey to Shetland, but rare"), the Atlantic coast of Spain (Schander et al. 2003) and from the western Mediterranean (Peñas et al. 1996). Van Aartsen et al. (1998) extend the distribution to Mauritania, Canary Islands and Cape Verde Islands. Van Aartsen (1987) states only that "Od. angusta occurs in the Atlantic as well as 
in the Mediterranean."

Remarks: The first author elevating this to a full species appears to be van Aartsen (1987), who separated it from the similar looking $B$. eulimoides, for which it has always been regarded as a variety (Jeffreys 1867, Marshall 1899b). Later it has been accepted by Peñas et al. (1996) and Schander et al. (2003). My source for identifying this species is the photograph in van Aartsen (1987), showing a shell much like B. eulimoides, but somewhat narrower. The main character van Aartsen mentions for distinguishing the two is that $B$. eulimoides have clearly prosocline growth-lines, while those of $B$. angusta are more or less vertical. This distinction is only easily visible on very fresh material. To distinguish it from $B$. scalaris, which is also stated to have orthocline growth-lines, he notes that it has a $\mathrm{H} / \mathrm{W}$ ratio $>2$, (against $<2$ ), and a shell shape like a slender oval (as against a shell of rissoid type). Further studies are needed for verifying that this is really a species belonging in the Norwegian fauna.

\section{Brachystomia carrozzai (van Aartsen, 1987)} Figure 28

Odostomia carrozzai nom. nov. pro Od. albella auct., not Lovén, 1846. - van Aartsen 1987:13, Figure 30

Odostomia carrozzai van Aartsen, 1987 - Peñas et al. 1996; Høisæter 2009

Brachystomia carozzai (van Aartsen) - Smith \& Heppell 1991; Schander 1995

Odostomia albella (Lovén) - Alder 1848; Jeffreys 1848, 1859, 1867; Friele 1874; G.O. Sars 1878; Norman 1879; Collin 1880, 1884; Jeffreys 1884; Petersen 1888; Marshall 1899; Høisæter 1986

Odostomia (Brachystomia ) albella (Lovén) - Winckworth 1932 Ptychostomon albellum (Lovén) - Kobelt 1903

Odontostomia (Auristomia) albella (Lovén) - Dautzenberg \& Fischer 1925

Brachystomia albella (Lovén) - Fretter et al. 1986; Graham 1988 Chemnitzia pallida (Montagu) (in part) - Clark 1855

Odostomia rissoides var. albella (Lovén) - Forbes \& Hanley $1850-51$

Type material: Holotype USNM 132482. [Od. albella (Lovén) Jeffreys. Figured type in Br. Conch.] van Aartsen 1987

Type locality: Not designated, supposedly British Isles

Material seen: Norway - Skagerrak, 1 spm, 5 shs; Hordaland, 1 spm; Nord-Trøndelag, 2 spms, 2 shs; Nordland, 3 shs. All identifications are tentative.

Description: Shell: Prosocline growth lines as in $B$. eulimoides. The last whorl narrower and less oval than for this species, around 0.6 of total height (from van Aartsen 1987). Also similar to $B$. scalaris (with orthocline growth lines) but less turriculate and with less convex whorls. The shell pictured in Figure 28 is the one that came closest to the figure by van
Aartsen (1987: Figure 30). Soft parts: Not known. Operculum: Not known.

Biology: Not known.

Distribution: Recorded by Friele (1874) from Manger, and Norman (1879) from Bukkasundet, very shallow water and intertidally. Both records are from around $60^{\circ} 15^{\prime} \mathrm{N}$ to $60^{\circ} 30^{\prime} \mathrm{N}$ in the Bergen area. The specimen from Foldafjorden $\left(64^{\circ} 40^{\prime} \mathrm{N}\right.$, 60-20 m, shell gravel with large amounts of tubes of the serpulid polychaete Hydroides), may be taken as the northern distributional limit for the species. Outside Norway it is known from Sweden and Denmark, the British Isles, and the Atlantic coast of France. Peñas et al. (1996) record several specimens from the western Mediterranean (southern coast of Spain). Van Aartsen et al. (1998) extend the distribution to Canary Islands and the Selvagens archipelago. Schander (1995) mentions a single specimen intermediate between typical $B$. eulimoides and $B$. carozzai from the Faroes, but finds it most likely that it is a specimen of the variable $B$. eulimoides.

Remarks: This is the species traditionally known as Odostomia albella, based on the detailed description of Jeffreys (1867). Already Forbes \& Hanley (1853:286) remarked that “...the O. albella of British writers (Alder 1848 and Jeffreys 1848)...is supposed to be the Turbonilla albella of Lovén, but the identification is not positive". This problem seems not to have been adressed properly until van Aartsen (1987) studied Lovén's type specimen of this species, and found it to be a specimen of $O$. unidentata. Van Aartsen introduced O. carrozzai as a replacement name for O. albella auct., not Lovén, 1846. The conclusion of van Aartsen concerning the misidentification of $O$. albella is supported by a remark in Fretter et al. (1986) that the specimen illustrated by Thorson (1946) and the shell drawn by Poul Winther supposedly selected by Thorson, both have protoconchs of the $O$. unidentata type. I base my interpretation on this species on the SEM-photo and description of B. albella in Fretter et al. (1986).

\section{Brachystomia eulimoides Hanley, 1844} Figure 29

Odostomia eulimoides - Hanley, 1844:18

Odostomia eulimoides Hanley - Forbes \& Hanley 1850-51; Jeffreys 1859; Collin 1884; Petersen 1888; van Aartsen \& al. 1984; van Aartsen 1987; Peñas et al. 1996; Høisæter 2009

Odostomia (Brachystomia) eulimoides (Hanley) - Winckworth 1932; Høisæter 1986

Zastoma eulimoides (Hanley) - Iredale 1915

Brachystomia eulimoides (Hanley) - Fretter et al. 1986; Graham 1988; Smith \& Heppell 1991; Schander 1995

Turbo pallidus Montagu, 1803:325

Odostomia pallida (Montagu) - Alder 1848; Jeffreys 1867; Friele 1874; G.O. Sars 1878; Norman 1879; Jeffreys 1884; Marshall 1899; Friele \& Grieg 1901

Chemnitzia pallida (Montagu) (in part) - Clark 1855 
Ptychostomon pallidum (Montagu) - Kobelt 1903

Odontostomia (Auristomia) pallida (Montagu) - Dautzenberg \& Fischer 1925

Voluta ambigua Maton \& Rackett, 1807:132

Odostomia ambigua (Maton \& Rackett) - Dautzenberg \& Fischer 1912; Thiele 1928

Brachystomia ambigua (Maton \& Rackett) - Ankel 1936

Odostomia crassa Thompson 1844:315

Turbonilla crassa (Thompson) - Lovén 1846a, b

Turbonilla oscitans Lovén, 1847:49

Type material: Not known

Type locality: Guernsey, Channel Islands.

Material seen: Norway - Skagerrak, 5 spms, 7 shs; NordTrøndelag, 4 shs; Nordland, 3 shs; England - Plymouth, 1 sh (ZMBN 15739). Many of the shells are tentative identifications.

Description: Shell: Prosocline growth lines, a dominating body whorl, whorls less convex than in B. scalaris, aperture oblong. The largest of the Norwegian species of Brachystomia, reaching at least $5 \mathrm{~mm}$ in length. In many cases I found it hard to distinguish between $B$. eulimoides and B. angusta, as the growth lines are not always easily interpreted. Soft parts: Not known. Operculum: Not known.

Biology: This species is reported to live on (the ears of) Pecten maximum, Aequipecten opercularis, and sometimes Turritella (Ankel 1959, Fretter et al. 1986); together with $B$. scalaris on Mytilus, and on Turritella in the Shetlands (Marshall 1899b); on oysters and mussels in northern Wales (Cole \& Hancock 1955); on mussel beds on the south coast of Ireland (McFadden \& Myers 1989). Two specimens in my material were taken off the ears of Pecten maximus on the Skagerrak coast (coll. and leg. P. Buhl Mortensen). It has been reported as rather common on the ears of Chlamys islandicus around Bodø (G.O. Sars 1878).

Distribution: From Norway reported by G.O. Sars (1878) from outside Bodø $\left(67^{\circ} 17^{\prime} \mathrm{N}\right)$ as rather common. G.O. Sars mentions that the only other reported Norwegian locality is Florø $\left(61^{\circ} 36^{\prime} \mathrm{N}\right)$. Apparently never since reported from Norway. The many specimens reported in Høisæter (1989) from Pomatoceros are due to a misidentification and in fact refer to Odostomia striolata. The two specimens taken off the ears of Pecten maximus from the Skagerrak coast most definitely belong to this species, while some of the empty shells assigned to this species might rather belong to $B$. angusta. Anyway I have shells from both Nord Trøndelag and Nordland that support the record of G.O. Sars from outside Bodø. Outside Norway it is known from Iceland, the Faroe Islands, the Swedish west coast (Schander 1995), and Denmark, Shetland, the coasts of Ireland and further south along the Atlantic coasts of Europe (Ankel 1936), and finally the western Mediterranean (Peñas et al. 1996). Van Aartsen et al. (1998) extend the distribution to Mauritania and the Azores.

Remarks: The name of this species has been discussed by several authors. Thus Iredale (1915) concludes that the name used by Jeffreys (1867) and most Scandinavian authors following him, Odostomia pallida (Montagu, 1803) is based on an indeterminable specimen and must be replaced by $O$. eulimoides Hanley, 1844. O. eulimoides has been used by most authors since then, but as a reaction to the reintroduction of $O$. ambigua (Maton \& Rackett, 1807) by Nordsieck (1972), van Aartsen et al. (1984) and Smith \& Heppel (1991) repeated and strengthened the arguments for $O$. eulimoides, which is now universally accepted as the name for this species.

\section{Brachystomia scalaris (MacGillivray, 1843) Figures 30-33}

Odostomia scalaris - Macgillivray, 1843:154

Odostomia scalaris Macgillivray - van Aartsen \& al. 1984; van Aartsen 1987; Peñas et al. 1996; Høisæter 2009

Odostomia (Brachystomia) scalaris (Macgillivray ) Winckworth 1932

Brachystomia scalaris (Macgillivray) - Smith \& Heppell 1991 Zastoma scalaris Macgillivray - Iredale 1915

Odostomia Rissoides Hanley, 1844:18

Odostomia rissoides Hanley - Jeffreys 1848; Forbes \& Hanley 1850-51; Jeffreys 1867, 1870; M. Sars 1870; Meyer \& Möbius 1872; Friele 1874; G.O. Sars 1878; Norman 1879; Collin 1880; Jeffreys 1884; Petersen 1888; Marshall 1899

Odostomia (Brachystomia) rissoides Hanley - Monterosato 1884; Høisæter 1986

Odontostomia (Brachystomia) rissoides (Hanley) - Dautzenberg \& Fischer 1925

Brachystomia rissoides (Hanley) - Ankel 1936; Fretter et al. 1986; Graham 1988; Høisæter 1989

Ptychostomon rissoides (Hanley) - Kobelt 1903

Chemnitzia pallida (Montagu) (in part) - Clark 1855

Odostomia nitida Alder, 1844:326 - Alder 1848; Jeffreys 1859; Collin 1884

Turbonilla (Odontostomia) nitida Alder - Malm, 1861

Odostomia alba Jeffreys, 1848:337 - Forbes \& Hanley 1850-51; Jeffreys 1859

Type material: Not known.

Type locality: Aberdeen in Scotland.

Material seen: Norway - Skagerrak, 65 spms; Hordaland, 820 spms; Møre og Romsdal 3 spms; Nord-Trøndelag, 30 spms; Nordland, at least 7 shs.

Diagnosis: Shell: Brachystomia with moderately prosocline growth lines, and a turreted shell shape with quite convex whorls and deep sutures. Rounded aperture. Protoconch (Figures 30 and 31) of type $\mathrm{C}$ (intorted) of less than one whorl and with a clear demarcation of the beginning of the first teleoconch whorl. Soft parts: Head foot complex (Figure 32, top) white with numerous small yellow pigment spots scattered over foot and tentacles, tentacles triangular with tentacular pads, mentum slightly expanded at the tip, eyes fairly large and 

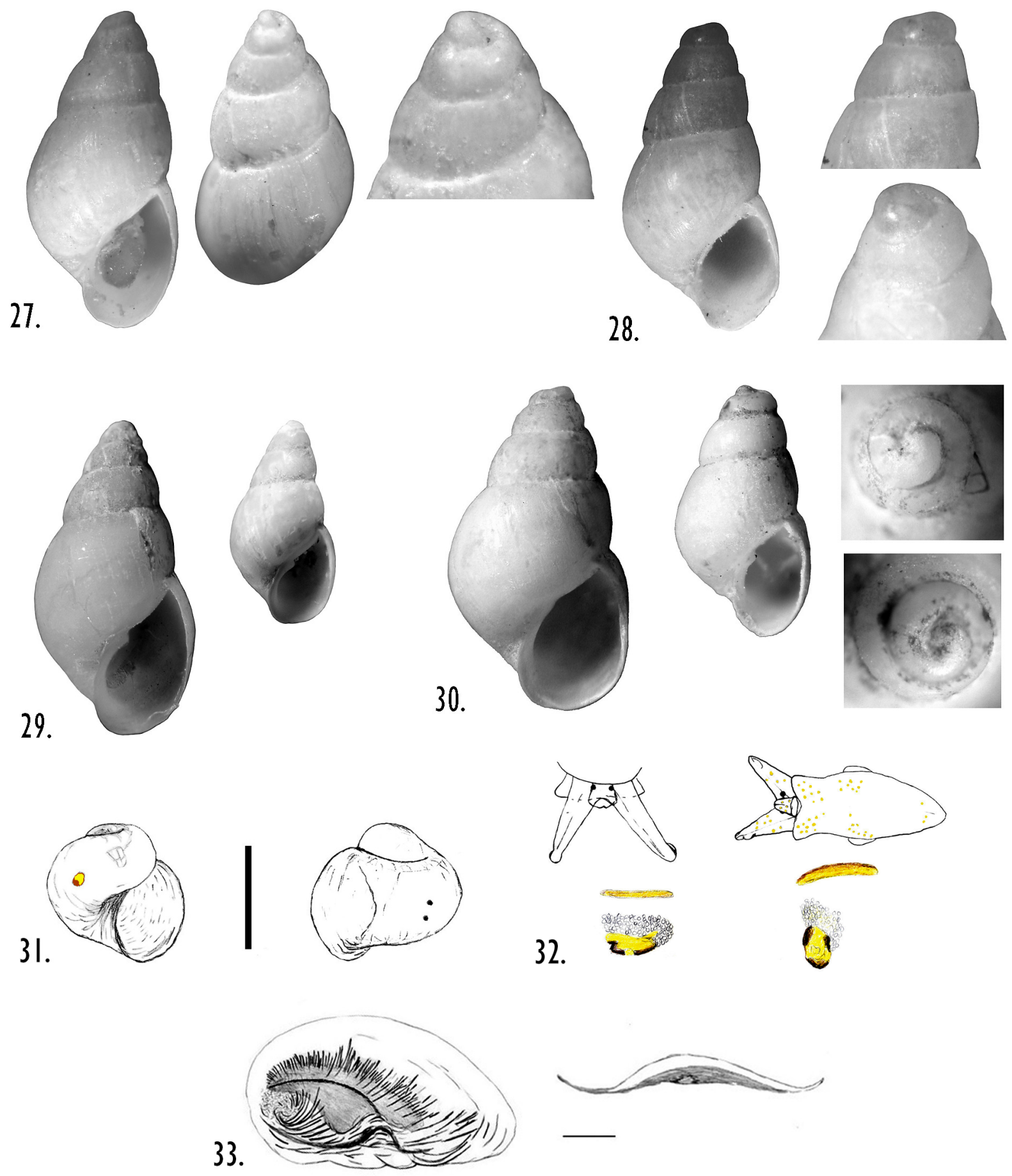

Figure 27. Brachystomia angusta. A specimen from Grimstad, Aust-Agder (58²0’’ $\left.8^{\circ} 35^{\prime} \mathrm{E}\right), 2.2 \mathrm{~mm}$ (G 33-71).

Figure 28. Brachystomia carrozzai. A specimen from Foldafjorden, $64^{\circ} 40.2^{\prime} \mathrm{N}, 11^{\circ} 07.5^{\prime} \mathrm{E}, 60-20 \mathrm{~m}, 2.1 \mathrm{~mm}$ (ZMBN 83083).

Figure 29. Brachystomia eulimoides. A specimen from Bøddelhaue, Grimstadfjorden $58^{\circ} 19.5^{\prime} \mathrm{N}, 8^{\circ} 35^{\prime} \mathrm{E}, 35 \mathrm{~m}, 4.1 \mathrm{~mm}$, and one from Vikkilen, Grimstad, 58²0.7’N, 8³6.7’E, 20 m, 2.7 mm (P.max.-86).

Figure 30. Brachystomia scalaris. A specimen from Hillersholmen, Raunefjorden $60^{\circ} 17.8^{\prime} \mathrm{N}, 5^{\circ} 11^{\prime} \mathrm{E}, 6-8 \mathrm{~m}, 2.25 \mathrm{~mm}$ (ZMBN 83114), and one from Knappensundet, Grimstadfjorden, (Hordaland), 60¹9’N, 5⒖8’E, 3.5 m, 1.75 mm (ZMBN 83111).

Figure 31. Brachystomia scalaris, postlarva. Scale bar $=300 \mu \mathrm{m}$.

Figure 32. Brachystomia scalaris, head-foot complex and pigmented mantle organ (not to scale).

Figure 33. Brachystomia scalaris, operculum, two views. Scale bar $=200 \mu \mathrm{m}$. 
not particularly close together. Pigmented mantle organ (Figure 32, bottom) yellow blotch with dark brown interrupted edges, masses of white 'bubbles' above and an oblong custard coloured gland further up. Operculum: (Figure 33), flat with only a slight thickening under the central part, no clear indentation for the columellar tooth.

Biology: B. scalaris seems to be a typical shallow water species, rarely found deeper than $15 \mathrm{~m}$ in our waters. It has most frequently been encountered as an ectoparasite of Mytilus edulis, but has been reported from a number of other molluscan hosts as well as free living in shallow water (Ankel \& Christensen 1963, Rasmussen 1973, Fretter et al. 1986). In my studies (Høisæter 1989), the species was found in samples dominated by Limaria hians and Modiolus, but also in samples of Pomatoceros reefs, and finally from haptera and stipes of Laminaria hyperborea in semi-exposed and fairly protected areas. In the first and last of these it was invariably the most numerous pyramidellid species. Like $B$. eulimoides primarily a mollusk-feeder, but my studies indicate that it occasionally co-occurs with other pyramidellids on Pomatoceros reefs.

Distribution: Rarely recorded from Norway before 1986. Norman (1879) reports it from Raunefjorden and Osterfjorden and cites earlier reports from Oslofjorden (from Jeffreys 1870). G.O. Sars (1878) records it from Oslofjorden, the southern coast and the west coast. In my material 13 samples with 34 specimens from Skagerrak, and 705 specimens from the Espegrend area. Further north 33 specimens and 39 shells, the northernmost empty shell from southwest of Bodø $\left(67^{\circ} 15^{\prime} \mathrm{N}\right.$, 50-20 m, shell gravel, slag and small stones). A sample from a shallow water algae station (containing more than 1200 Bittium reticulatum) at Fløan, bay southeast of Stamnes $\left(64^{\circ} 29^{\prime} \mathrm{N}\right.$, 3-10 m, soft bottom with Laminaria saccharina, Chorda filum and other algae) contained at least $30 \mathrm{~B}$. scalaris. This is thus at present the northern limit for the species (based on living material). Outside Norway it is known from Sweden and Denmark, even the western part of the Baltic Sea, all around the North Sea, the western and southern coasts of Ireland and the British Isles, further south along the Atlantic coasts of Europe (Ankel 1936) and the western Mediterranean (Peñas et al. 1996). Van Aartsen et al. (1998) extend the distribution to Mauritania, and also cite earlier records from Madeira, the Selvagens archipelago and the Azores.

Remarks: Iredale (1915) reinstated the oldest name, $O$. scalaris Macgillivray, which had been replaced by $O$. rissoides Hanley by Jeffreys (1848). The reason for this replacement was that Jeffreys regarded all the British pyramidellids as species of Odostomia. When the group was split up into several genera, the homonymy of Melania scalaris Philippi (a synonym of Pyrgiscus jeffreysii) with $O$. scalaris was no longer a problem (see van Aartsen 1987).

\section{'Brachystomia' lukisi Jeffreys, 1859}

Figures 34-37

Odostomia Lukisii Jeffreys, 1859:112.

Odostomia lukisii Jeffreys - van Aartsen et al. 1984; van Aartsen 1987; Peñas et al. 1996

Odostomia Lukisi Jeffreys - Jeffreys 1867

Odostomia lukisi Jeffreys - Marshall 1899; Warén 1980; Høisæter 1968, 2009

Odostomia (Brachystomia) lukisi Jeffreys - Høisæter 1986

Odostomia (Brachystomia) lukisii Jeffreys - Winckworth 1932

Brachystomia lukisi (Jeffreys) - Fretter et al. 1986; Graham 1988; Høisæter 1989

Brachystomia lukisii (Jeffreys) - Smith \& Heppell 1991

Ptychostomon lukisi (Jeffreys) - Kobelt 1903

Type material: Twelve syntypes, USNM 132156 (Warén 1980)

Type locality: Not designated, but Guernsey, Channel Islands is the locality of the syntypes.

Material seen: Norway - Skagerrak, 2 shs; Hordaland, 245 spms.

Diagnosis: Shell: Small (usually less than $2.8 \mathrm{~mm}$ ), glossy, ivory white. Protoconch intorted, extremely flat (type C) (Figure 36). Growth lines more or less vertical. Soft parts: Tentacles (Figure 35 top) short and wide, apparently without tentacular pads, eyes very close together, mentum characteristically cleft, with diverging ends. Pigmented mantle organ (Figure 35 bottom) in two parts, long and yellow above and short oval, brownish yellow below. Operculum: (Figure 37) with a notch at he columellar side, a ventral thickening in the middle, but no typical 'anchor' of the 'Odostomia'-type (see Figure 3). Frequently with corroded protoconch and corrosion marks on the whorls (Figure 34).

Biology: According to Fretter et al. (1986) frequently found in association with fairly large assemblages of Pomatoceros, and also with Serpula and Spirorbis. This is also the case for the material from Norway, but the association with Pomatoceros is far less strong than what was observed for $O$. striolata and O. turrita (Høisæter 1989). Thus it was not found at the Pomatoceros-dominated substrate at the Hillersholmen locality, and the three samples at the Knappensundet locality in which it was found in highest numbers (in one sample even with higher abundance than any other pyramidellid) were all typical Limaria-Modiolus dominated samples.

Distribution: A southern, shallow water species, in Norway only recorded from the Espegrend area except for two shells from Skagerrak and a single older record from Florø $\left(61^{\circ} 36^{\prime} \mathrm{N}\right)$ (Høisæter 1968). All but two specimens in my material from 11 samples from the locality in Knappensundet (Straume bridge) in Grimstadfjorden $\left(60^{\circ} 19^{\prime} \mathrm{N}\right)$ (see Høisæter 1989). Outside Norway it is reported as occurring sparingly both in the Atlantic and the Mediterranean (van Aartsen 1987). According to Graham (1988) it is among the commonest of intertidal 
pyramidellids on the west coast of the British Isles and the southern Channel, but is absent from the North Sea. Reported from the western Mediterranean by both van Aartsen et al. (1984) (Algeciras Bay) and Peñas et al. (1996). Van Aartsen et al. (1998) extend the distribution to Mauritania, the Canary Islands, Madeira, and the Azores.

Remarks: Spelling of the specific name varies. Originally (Jeffreys 1859) spelled it with a double ' $i$ ' at the end, but later (Jeffreys, 1867) with a single ' $i$ '. It is explicitely named after Dr. F.C. Lukis. The choice between the two spellings should be solved based on Article 31.1 of ICZN.The crucial point is the question of whether the name is based on a personal name that is Latin, or from a modern name that is latinized. I interpret Jeffreys' change of mind as an indication that he did not intend to latinize the name. This is not a Brachystomia s.s., as is clearly seen from the soft parts. It occupies, taxonomically, an isolated position in the Norwegian pyramidellid fauna. The population of this species in Norwegian waters may fluctuate wildly from decennium to decennium, dependent on the amount of larvae brought in with water masses of varying origin and temperature.
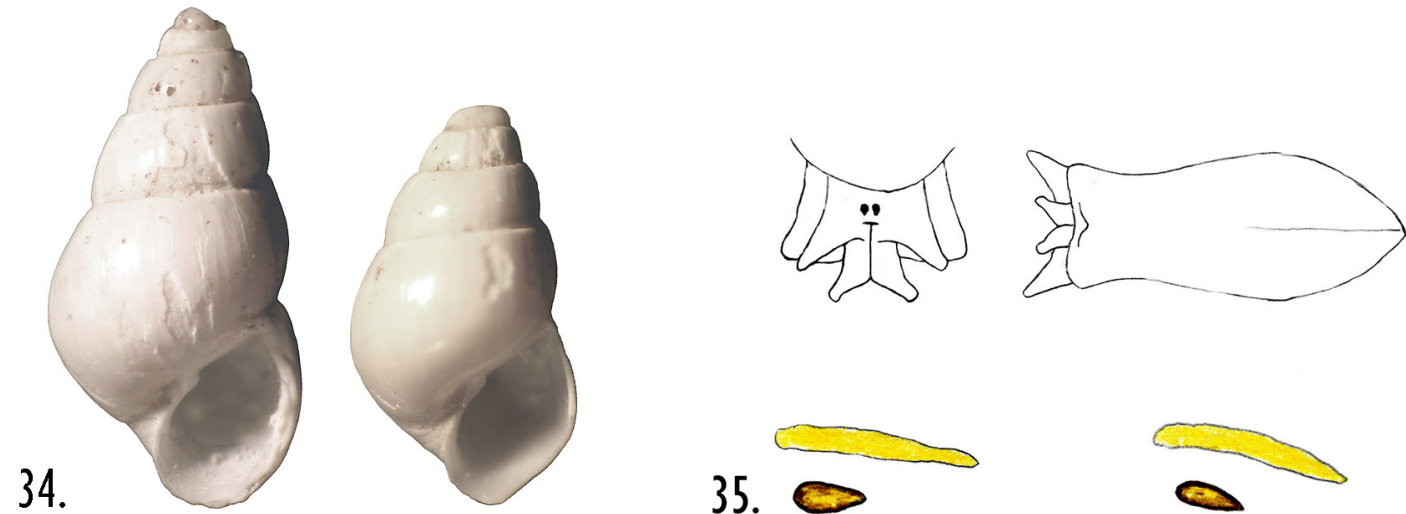

Pyramidellids with, usually, small ( $<5.5 \mathrm{~mm}$ long), broadly conical or ovate shells, of not more than seven whorls. Sculpture, if any, confined to microscopic spiral striae or fine lines of growth. Shell white, sometimes with a grayish, yellowish or bluish tinge. Aperture rhomboid to oval, usually acute-angled above. Columella usually gently curved, merging almost imperceptibly with the base of the penultimate whorl. A columellar fold always present. Protoconch partly submerged in the teleoconch, its angle of inclination varying, though usually around $90^{\circ}$ (type A, and B). Operculum with an opaque, opercular 'anchor' of varying thickness and with or without a distinct indentation and groove created by the columellar tooth.

In northern Europe, this is the dominating group of pyramidellids, both in number of species and number of specimens. Many of the forms here included are extremely common in their particular habitats in shallow water. I have included nine species from the treated region in this genus, but do not exclude the possibility of reducing the number further when more is known about all of the species.

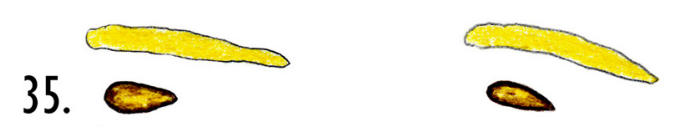

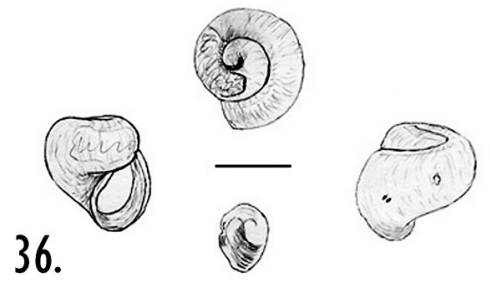

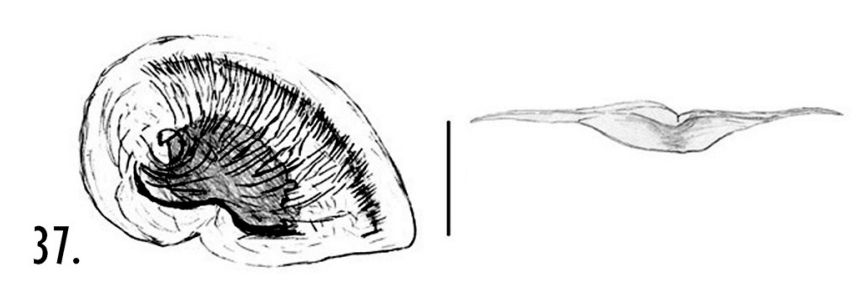

Figure 34. 'Brachystomia' lukisi. Two specimens from Knappensundet, Grimstadfjorden (Hordaland), $60^{\circ} 19.3^{\prime} \mathrm{N}, 5^{\circ} 15.8^{\prime} \mathrm{E}, 8 \mathrm{~m}, 2.7$ and $1.75 \mathrm{~mm}(\mathrm{ZMBN} 82536)$.

Figure 35. 'Brachystomia' lukisi, head-foot complex and pigmented mantle organ (not to scale).

Figure 36. 'Brachystomia' lukisi, juvenile. Scale bar $=300 \mu \mathrm{m}$.

Figure 37. 'Brachystomia' lukisi, operculum, two views. Scale bar $=200 \mu \mathrm{m}$. 
Key to the species of Odostomia, based on shell morphology

1a. Protoconch around $120^{\circ}$ Odostomia striolata

1b. Protoconch $90^{\circ}$ (type A) 2

2a. Protoconch partly submerged, sometimes with series of list-like teeth inside of outer lip, with a narrow spiral incision around periphery 'Odostomia' conoidea

2b. Protoconch completely exposed .3

3a. Shell tall (to $9 \mathrm{~mm}$ ), pointed, often pinkish or brown, often with series of list-like teeth inside of outer lip, clearly prosocline growth lines .. Odostomia conspicua

3b. Shell not exceeding $5 \mathrm{~mm}$, white, not with series of list-like teeth inside of outer lip . .4

4a. Whorls well rounded, orthocline growth lines, distinct umbilicus Odostomia acuta

4b. Whorls convex, suture deep, prosocline growth lines Odostomia umbilicaris

4c. Whorls more or less flat-sided, umbilicus absent or chink-like .5

5a. Shell rarely exceeding $3 \mathrm{~mm}$, prosocline growth lines Odostomia turrita

5 b. Shell rather pointed, not exceeding $3.5 \mathrm{~mm}$, orthocline growth lines Odostomia plicata

5c. Shell a more or less broad cone, periphery slightly keeled $\ldots 6$

6a. Shell not exceeding $5 \mathrm{~mm}$, prosocline growth lines, periphery usually distinctly keeled Odostomia unidentata

6b. Shell not exceeding $3.5 \mathrm{~mm}$, very broad cone, protoconch completely exposed ....Odostomia cf. turgida

\section{Odostomia acuta Jeffreys, 1848}

Figures 38-42

\section{Odostomia acuta - Jeffreys, 1848:338}

Odostomia acuta Jeffreys - Forbes \& Hanley 1850-51; Jeffreys 1859, 1867, 1870; M. Sars 1870; Friele 1874; G.O.Sars 1878; Collin 1880, 1884; Jeffreys 1884; Petersen 1888; Marshall 1899; Friele \& Grieg 1901; Dautzenberg \& Fischer 1912; Winckworth 1932; Spärck \& Thorson 1933; Warén 1980; van Aartsen \& al. 1984; Høisæter 1986; van Aartsen 1987; Høisæter 1989; Smith \& Heppell 1991; Peñas et al. 1996; Schander et al. 2003; Høisæter 2009

Chemnitzia acuta Jeffreys (in part) - Clark 1855

Ptychostomon acutum (Jeffreys) - Kobelt 1903

Odontostomia (Nisostomia) acuta (Jeffreys) - Dautzenberg \& Fischer 1925
Type material: Twenty-one syntypes, no locality, USNM 753712

Type locality: Not designated, presumably British Isles (Warén 1980)

Material seen: Norway - Skagerrak, 53 spms; Hordaland, 104 spms; Møre og Romsdal 20 spms; Nord-Trøndelag, 3 spms; Nordland, 13 spms; Troms 3 shs.

Diagnosis: Shell: Large conical shells. Body whorl large and round. Aperture oval. Distinct umbilicus. Columellar tooth fairly prominent. Protoconch large with completely exposed nucleus. Soft parts: Foot wide. Parallel-sided tentacles with blunt tips (Figures 40 and 41), no tentacular pads. Mentum with upturned edges forming a gutter. Pigmented mantle organ (Figure 41) of varying length, alternatively dark brown and yellow segments in a linear row, elongated light yellow gland (?) further behind. Head-foot region (Figure 40) with characteristic purplish-brown colour pattern. Operculum: With very strong opercular 'anchor' (Figure 42).

Biology: According to Fretter et al. (1986) probably feeding on bryozoans. Found in large numbers on the gelatinous tubes of the polychaete Myxicola infundibulum (Høisæter 1989). Most likely also associated with other tube building polychaetes.

Distribution: Reported from all along the coast, with the exception of east Finnmark (G.O. Sars 1878). In my material competing with $O$. turrita and $O$. unidentata in being the commonest species of Odostomia (s.s.). The northernmost shells recorded from a station in Andfjorden, east of Andøya $\left(69^{\circ} 17^{\prime} \mathrm{N}, 65-80 \mathrm{~m}\right.$, coarse shell gravel). Otherwise, fairly evenly distributed along the coast. Two samples from Hordaland with respectively 58 and 29 specimens, and a sample in the material from Skagerrak with 21 specimens. Otherwise only one to six specimens in each sample. Outside Norway it is known from the Swedish west coast and Kattegatt and the northern part of the Sound. All along the western coasts of the British Isles and Ireland, scattered also on the the North Sea coast of Britain (probably absent from the southern parts of the North Sea) (Fretter et al. 1986). Not known from Iceland or the Faroes (Schander 1995). Found along the Atlantic coasts of France and Spain and into the western Mediterranean (van Aartsen et al. 1984, Peñas et al. 1996). Van Aartsen et al. (1998) extend the distribution to Mauritania, Cape Verde Islands, the Canary Islands, and Madeira.

Remarks: Specimens inspected alive are easy to identify, but long dead shells are hard to distinguish from $O$. unidentata. O. acuta is included in the 16S-analysis of Schander et al. (2003), who concluded that its inclusion in Odostomia (represented by $O$. turrita and a few species not found in the Norwegian fauna, but not the type species, O. plicata) is "problematic, as it alternately clusters with 'Megastomia' (i.e. 'Odostomia' conoidea and 'O.' corimbensis), or is basal to other Odostomia species". Morphologically $O$. acuta is most definitely closer to e.g. O. turrita (and especially to $O$. unidentatata) than to $O$. conoidea, and the table of pairwise differences in Schander et al. (2003) support this relationship, as the character difference 
between $O$. acuta and ' $O$.' conoidea is more than twice the difference between $O$. acuta and O. turrita. O. acuta is among the most common pyramidellids along the Norwegian coast, especially as empty shells.

\section{Odostomia umbilicaris (Malm, 1861)}

\section{Figure 43-44}

Turbonilla (Odontostomia) umbilicaris Malm, n.sp. - Malm, 1861:623

Odostomia umbilicaris (Malm) - Jeffreys 1867; Friele 1874; G.O. Sars 1878; Marshall 1899; Winckworth 1932; Høisæter 1986; Fretter et al. 1986; Graham 1988

Odostomia acuta var. umbilicaris (Malm) - Smith \& Heppell 1991

Ptychostomon umbilicare (Malm) - Kobelt 1903

Type material: Göteborg (?)

Type locality: Löken, Western Sweden (?)

Material seen: Norway - Skagerrak, 4 spms (tentative identification).

Diagnosis: Shell: Cyrtoconoid moderately sized shell. Convex whorls and deep suture. Large umbilicus. Partly submerged protoconch. Prominent columellar tooth. Soft parts: Not known. Operculum: Not known.

Biology: Not known, but reported by (Malm 1861) together with Modiolus adriaticus on the Swedish west coast.

Distribution: According to Friele (1874) not rare at one of his localities, Biskopshavn, (in Bergen) 55-75 m. Not recorded by Norman (1879) and a record in G.O. Sars (1878) is only a repetition of the one in Friele (1874). (The two shells depicted in Figure 44 are from Friele's locality, Biskopshavn, and identified by him). This record of Friele seems to be the only one from Norwegian waters (Malm's record from 150 fathoms, Eggers Bank is intractable). In my material, four specimens from the Skagerrak region, and probably several others listed as O. acuta (following van Aartsen 1987, see Remarks below). Outside Norway it is recorded from the Swedish west coast, the northern and western coasts of the British Isles and south west Ireland (Jeffreys 1867, Marshall 1899b, Fretter et al. 1986). In all newer literature regarded as a synonym of $O$. acuta, following van Aartsen (1987).

Remarks: Authorship is usually attributed to "Malm, 1863', but the species was briefly described already in Malm (1861). Van Aartsen (1987) expressed as his opinion that the $O$. umbilicaris described and figured by Jeffreys (1867) (at left in Figure 43), is a form of $O$. acuta. He 'supports' this opinion by showing photographs of Jeffreys' 'type' of $O$. umbilicaris and a shell of $O$. acuta from his own collection. He states that “... these shells (to) differ only in its more shiny surface and its more convex whorls." He could not compare his $O$. acuta with Malm's unavailable type of $O$. umbilicaris however, so that there might still be doubts as to the identity of the two nominal species. I find that the differences between the two shells figured in van Aartsen (1987) are striking, and in the material I have seen they seem to be rather constant. Schander (1995) presents a photograph of what he calls $O$. acuta from the Koster area in western Sweden (centre in Figure 44). This has all the attributes of Jeffreys' concept of O. umbilicaris, but Schander does not comment further on the relationship between $O$. acuta and O. umbilicaris. Both Jeffreys (1867) and Marshall (1899b) describe the distinction between these two species: "This species $[0$. acuta] may be distinguished from $O$. umbilicaris by its greater solidity, the periphery being always keeled, the spire much longer, and the whorls compressed instead of convex" (Jeffreys 1867:132)." It [O. umbilicaris] is most like a stumpy $O$. acuta, but the latter is more solid and conical, the whorls less tumid and the last whorl smaller proportionally." (Marshall 1899b:231). Fretter et al. (1986) regard O. umbilicaris to be the most easily identified of the British species of Odostomia, based on just those characters van Aartsen mentions. Fretter et al. do discuss an additional character, however, not mentioned by van Aartsen (1987), in spite of this character being regarded as the most important for distinguishing between a number of closely similar pyramidellids, viz. the inclination of the growth lines. This inclination is shown by Fretter et al. (1986) to be from 8 to 10 degrees for O. acuta, and from 24 to 33 degrees for 0 . umbilicaris. If these measurements are representative and correct, there is no possibility that the two are conspecific. Until living specimens are available for analyses, I regard it as prudent to regard the two as distinct and keep them apart in fauna lists.

\section{'Odostomia' conoidea (Brocchi, 1814)} Figures 45-48

Turbo conoideus Brocchi, 1814:659; pl. 16, Figure 2 Odostomia conoidea (Brocchi) - Forbes \& Hanley 185051; Jeffreys 1867, 1870; G.O. Sars 1878; Norman 1879; Collin 1880; Jeffreys 1884; Petersen 1888; Marshall 1899; Winckworth 1932; Høisæter 1986; Peñas et al. 1996; Høisæter 2009; Öztürk et al. 2013

Odostomia (Megastomia) conoidea (Brocchi) - van Aartsen 1987

Megastomia conoidea (Brocchi) - Smith \& Heppell 1991; Schander et al. 2003

Chemnitzia conoidea (Brocchi) - Clark 1855:422

Ptychostomon conoideum (Brocchi) - Kobelt 1903

Odontostomia conoidea (Brocchi) - Dautzenberg \& Fischer 1925

Odostomia polita (Bivona, 1832) - van Aartsen 1987

Turbonilla plicata (Montagu) - Lovén 1846a, b not O. plicata (Montagu, 1803)

Type material: In Museo civico di storia naturale di Milano (Pinna \& Spezia 1978:162, pl. 53, Figure 4). 
38.

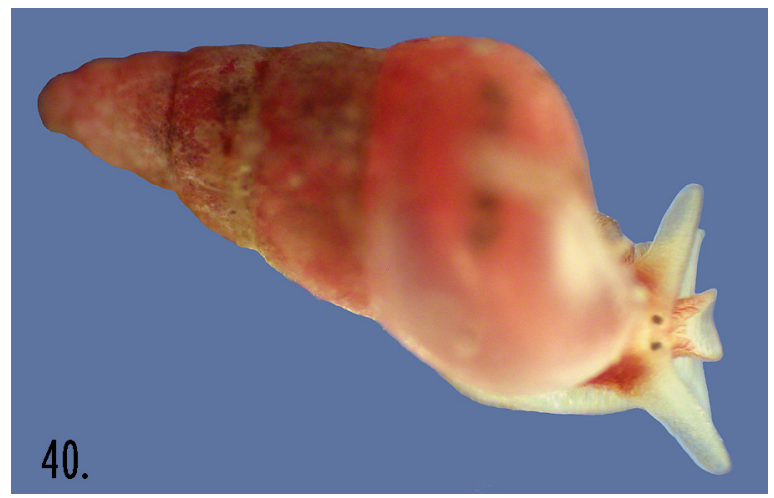

42.

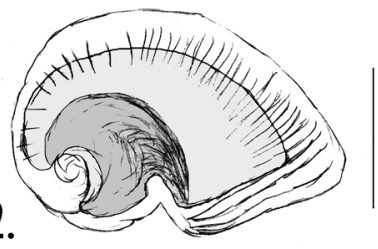

39.
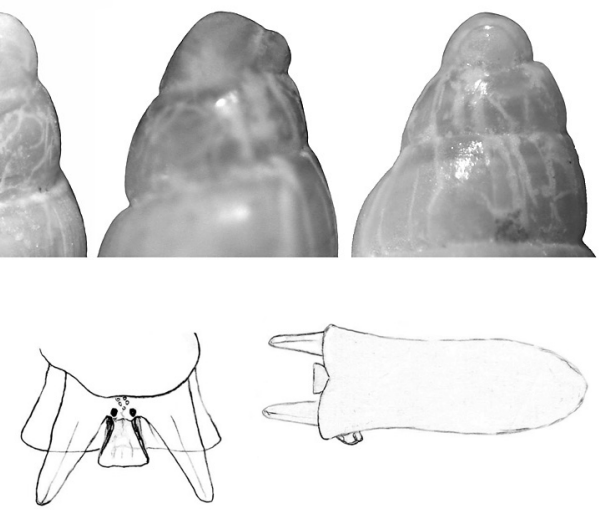

41.
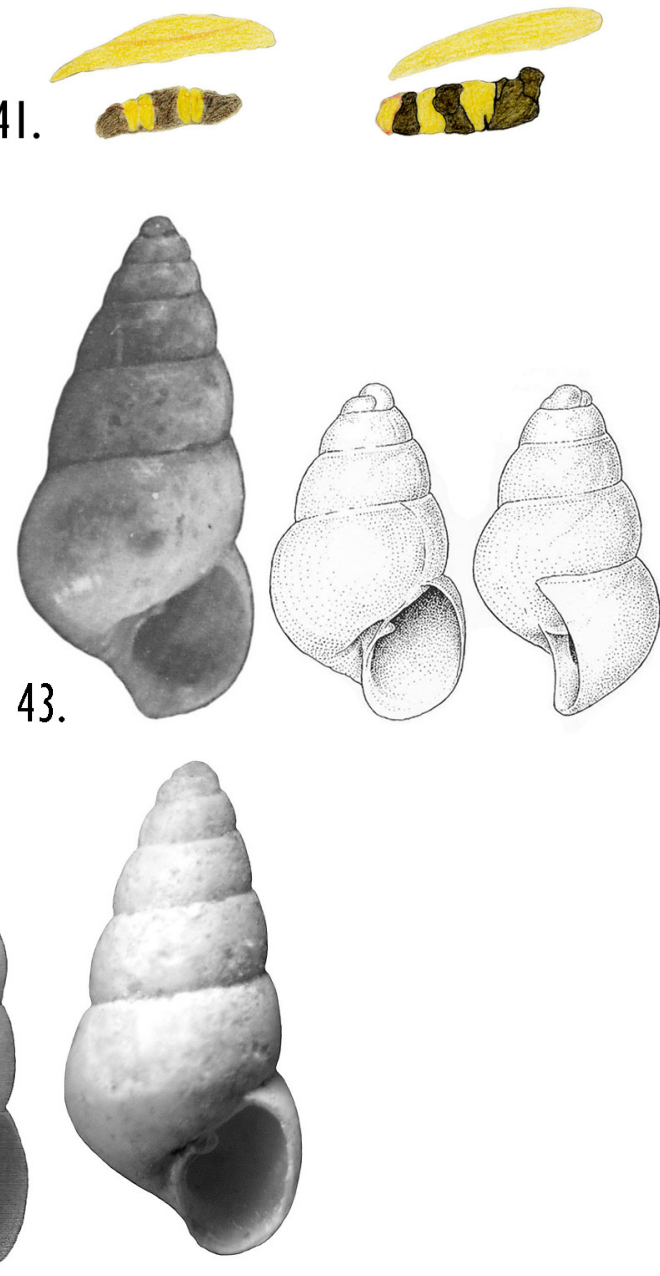

Figure 38. Odostomia acuta. Two specimens from Grimseidpollen, W of Pålsholmen, $60^{\circ} 16^{\prime} \mathrm{N}, 5^{\circ} 16^{\prime} \mathrm{E} 20-23 \mathrm{~m}, 2.4$ and $1.45 \mathrm{~mm}$ (ZMBN $82595)$.

Figure 39. Odostomia acuta, protoconch of specimen from the same locality as in Figure 36, three orientations Figure 40. Odostomia acuta. A specimen from Bukkasundet, Raunefjorden, $60^{\circ} 14.2 \mathrm{~N}, 05^{\circ} 12.3^{\prime} \mathrm{E}, 15 \mathrm{~m}, 3.8 \mathrm{~mm}$.

Figure 4l. Odostomia acuta, head-foot complex and pigmented mantle organ (not to scale).

Figure 42. Odostomia acuta, operculum, two views. Scale bar $=400 \mu \mathrm{m}$.

Figure 43. Odostomia umbilicaris. Two illustrations from the literature. From van Aartsen (1987) at left and Fretter et al. (1986) at right. The shell at left is Jeffreys' 'type', USNM 132020, the one at right is a shell from the Hebrides.

Figure 44. Odostomia umbilicaris. A specimen from the Swedish west coast (Schander 1995, as O. acuta) between two specimens from Biskopshavn, Bergen, $60^{\circ} 25.4^{\prime} \mathrm{N}, 05^{\circ} 17.6^{\prime} \mathrm{E}, 50-60 \mathrm{~m}$, (ZMBN 35030), both $2.95 \mathrm{~mm}$, coll, and det. Friele. 
Type locality: Tertiary fossil from Toscana, Italy.

Material seen: Norway - Skagerrak, 30 spms, 7 shs; Hordaland, 14 spms, 3 shs; Møre og Romsdal, 11 spms, at least 9 shs; Nord-Trøndelag, 3 spms, 4 shs; Nordland, 10 spms.

Diagnosis: Shell: (Figure 45) to $5 \mathrm{~mm}$, milky white, almost opaque; very smooth and polished, with a glossy surface. Usually with a narrow spiral incision around the periphery of the body whorl (Figure 45 right). Protoconch (Figure 46) partly submerged in first postlarval whorl. Umbilicus usually a narrow chink, but in large specimens a deep hollow. Tooth strong and prominent. Often, but not always, with spiral ridges on inside of outer lip. Soft parts: Mentum deeply cleft and diverging. Eyes small and close together. The front of the foot strongly ciliated (Figure 47 left). Pigmented mantle organ (hard to see clearly through the shell) elongated, almost linear, reddish yellow, with numerous small, yellow-white spots in a row above the gland (Figure 47 right). Operculum: (Figure 48) of same type as $O$. acuta (underside not studied).

Biology: Usually found at intermediate depths, from 50-60 to $200 \mathrm{~m}$. According to Fretter et al. (1986) usually in association with the starfish Astropecten irregularis. "Food. Presumably the starfish". This needs verification, as echinoderms are not among the usual hosts for pyramidellids.

Distribution: In Norway reported from the southern and western coast by G.O. Sars (1878) and from the Bergen area by Norman (1879). In my material thirteen samples from Skagerrak, 29 specimens and an additional 54 shells, more or less evenly distributed north to Bindalsfjorden (c. $65^{\circ} \mathrm{N}$ ). Further north nine specimens from around Bodø. A large (5.0 $\mathrm{mm})$ specimen in Saltfjorden $\left(67^{\circ} 10^{\prime} \mathrm{N}, 170-90 \mathrm{~m}\right.$, Modiolula phaseolina bottom). Outside Norway it is known from the Swedish west coast, the west and south coasts of the British Isles and Ireland and further south along the Atlantic coasts of France and Spain and the Mediterranean (Fretter et al. 1986, Peñas et al. 1996, Öztürk et al. 2013). Apparently very common in the Mediterranean, and by Öztürk et al. listed as the most abundant Odostomia distributed along the Turkish coast. By van Aartsen et al. (1998) stated to be abundant also along the coast of Mauritania and the Canary Islands.

Remarks: Best identified by the combination of the partly submerged protoconch (nucleus partly hidden by first postlarval whorl) and the spiral incision around the periphery of each whorl, in addition to the solid, glossy shell. Sufficiently different from Odostomia plicata to be placed in another genus. This is supported by the molecular analysis of Schander et al. (2003). In this analysis $O$. conoidea is (following van Aartsen) placed in the (sub)genus Megastomia at the outset, a decision they find to be supported by their molecular data. There is however no convincing reason to put it in the nominal genus Megastomia, which is based on Odostomia conspicua which, in my opinion is a typical Odostomia s.s. and has few traits in common with $O$. conoidea. According to Schander et al., $O$. corimbensis Schander, 1993 is another member of this genus. Yet another is $O$. polita (Bivona, 1832) described from Palermo,
Sicily, but listed as a synonym of $O$. conoidea by van Aartsen (1987). A final possible congener is O. harveyi van Aartsen \& Smith, 1996 from the upper slope in the northeast Atlantic, a species lacking a columellar tooth. The spiral ridges (or list like 'teeth') on the inside of the outer lip have been noted as an important character, and even of generic significance (distinguishing Megastomia from Odostomia s.s., see van Aartsen 1987). This character is very unreliable, however, as many shells are completely smooth inside the outer lip.

\section{Odostomia conspicua Alder, 1850}

Figures 49-50

\section{Odostomia conspicua - Alder, 1850:359}

Odostomia conspicua Alder - Forbes \& Hanley 1850-51; Jeffreys 1859, 1867, 1869; Marshall 1900; Winckworth 1932; Peñas et al. 1996; Høisæter 2009; Öztürk et al. 2013

Odostomia (Megastomia) conspicua Alder - Monterosato 1884; van Aartsen 1987

Odontostomia (Megastomia) conspicua (Alder) - Dautzenberg \& Fischer 1925

Megastomia conspicua (Alder) - Smith \& Heppell 1991

Ptychostomon conspicuum (Alder) - Kobelt 1903

Chemnitzia acuta Clark (in part) - Clark 1855

Type material: Lectotype (?) USNM 133036 "Fig'd type in Br. Conch." 8.5 mm (van Aartsen 1987).

Type locality: Douglas, Isle of Man?

Material seen: Norway - Skagerrak, 9 spms, 3 shs.

Diagnosis: Shell: An elongated and large (reported to reach $9 \mathrm{~mm}$, van Aartsen 1987) sometimes somewhat asymmetrical cone. Prosocline growth lines; keel-like angulation of periphery of body whorl (especially on younger specimens). Aperture rhomboidal. Protoconch large and with nucleus completely exposed. Soft parts: (in conserved specimen) uniform yellowish white, as opposed to $O$. unidentata which has a profusion of lead-gray pigmentation, and $O$. acuta with purplish brown pattern. Eyes very large and farther apart than in any other Norwegian species of the family. Operculum: Not studied.

Biology: Not known.

Distribution: In Norway reported from the Skagerrak (Loshavn, Vest Agder, $58^{\circ} 03^{\prime} \mathrm{N}, 06^{\circ} 49^{\prime} \mathrm{E}, 35-55 \mathrm{~m}$ ) by G.O. Sars (1878). In my material from Skagerrak, ten samples with nine specimens and some shells. Not found further north along the coast. Outside Norway it is known from Bohuslän, Shetland (Jeffreys 1867); possibly from the Scottish North Sea coast, (Jeffreys 1867; McKay \& Smith 1979); from Orkneys and Shetland south along the west coast of Europe to the Mediterranean, and a few records from Madeira and the Canary Islands (Fretter et al. 1986, Peñas 1996, van Aartsen et al. 1998, Öztürk et al. 2013).

Remarks: My specimens from the Skagerrak, ranging in size from 2.5 to $4.75 \mathrm{~mm}$, mostly fit the description of $O$. 
conspicua as found in Fretter et al. (1986) and Peñas et al. (1996). The similarity to the type specimen (USNM 133036) illustrated in van Aartsen (1987) is not convincing, but this specimen is very large, c. $8.5 \mathrm{~mm}$ long with eight teleoconch whorls. A characteristic feature of my shells is the slow increase in the diameter of the first couple of whorls, giving the spire an almost double concave outline. The colour of one of the specimens is slightly reddish (periostracum), but the other two are translucent yellowish-grey. The immediate impression is that the protoconch is very large, but this may be because it is placed very high and free on top of the whorls, and the first teleoconch whorl is rather narrow (Figure 50). Measurements show the protoconch to be only slightly larger than the one of O. unidentata, which, however is more immersed in the first teleoconch whorl.

\section{Odostomia plicata (Montagu, 1803)}

Figure 51

\section{Turbo plicatus Montagu, 1803:325}

Odostomia plicata (Montagu) - Forbes \& Hanley 1850-51; Jeffreys 1867; Friele 1874; Collin 1880, 1884; Jeffreys 1884; Petersen 1888 (?); Marshall 1900; Winckworth 1932; van Aartsen \& al. 1984; Fretter et al. 1986 (in part); Høisæter 1986; van Aartsen 1987; Smith \& Heppell 1991; Peñas et al. 1996; Öztürk et al. 2013

Odostomia cf. plicata (Montagu) - Høisæter 2009

Odostomia (Brachystomia) plicata (Montagu) - Monterosato 1884

Chemnitzia plicata (Montagu) - Clark 1855

Ptychostomon plicata (Montagu) - Kobelt 1903

Odontostomia plicata (Montagu) - Dautzenberg \& Fischer 1925

\section{Type material:}

Type locality: Salcombe Bay, Devonshire, Great Britain (Peñas et al. 1996).

Material seen: Norway - Hordaland, 2 shs (ZMBN 16633), identified by Friele (1874). See further Distribution below.

Diagnosis: Shell: According to van Aartsen (1987) with nearly vertical (orthocline) growth lines, no umbilicus and only slightly rounded whorls. According to Jeffreys (1867), who compares it with $O$. turrita, it is "..narrower and slenderer, thin, transparent, and much more glossy, having a longer and tapering spire, a slight suture, nearly flat whorls, a differently shaped mouth, and no peripheral keel." Max. length c. $3.5 \mathrm{~mm}$. Soft parts: "Body whitish, with minute and close-set yellow specks; snout (i.e. mentum) small, wedge-shaped, flexible and extensile; tentacles leaf-like, and presenting three equal-sized, angular and flattened sides, which are folded a little inwards, tips rounded but not much inflated; eyes not quite so close together as in some other species, seated on the tentacles, at their inner bases; foot squarish in front and bluntly pointed behind, sole slightly grooved lengthwise on the posterior half.
Operculum: Not known.

Biology: Ankel (1939, 1949a,b, 1959) have described in detail how it feeds on Pomatoceros, but probably based on misidentified $O$. turrita.

Distribution: Probably not a Norwegian species. O. plicata has been recorded at various times as a Scandinavian species, but every time refuted by a later author. I have looked at a couple of the shells Friele (1874) assigned to O. plicata (see Material seen, above), which were later dismissed as misidentifications by G.O. Sars (1878:374) and Norman (1879), and I agree that these are unlikely to belong to $O$. plicata. Outside Norway it is reported from all around the British Isles including the Scottish North Sea coast, the north of France, and the Mediterranean (McKay \& Smith 1979, Fretter et al. 1986, Peñas et al. 1996; Öztürk et al. 2013).

Remarks: Unfortunately I have not had access to living specimens of this species, the type of Odostomia. The description of the head-foot complex of Jeffreys, cited above, is not very helpful, except for the mention of the "minute and close-set yellow specks". Its closest relative morphologically appears to be $O$. turrita, a species without any such specks (see Figures 59 and 61). According to Jeffreys (1867) O. turrita has often been mistaken for $O$. plicata. He cautions that due to the frequent confusion with $O$. turrita, he can vouch for only records from the south and southwest of the British Isles, and he regards it as a southern species. According to Marshall (1900) "This is not a variable species, and no mistake ought to be made about it. It is long, narrow, and tapering, with compressed whorls and shallow sutural lines." The rightmost photograph shown in Figure 51 above is of poor quality, but fits the description in Jeffreys and Marshall very well. All specimens from Norway I have seen that might be conspecific with the three shown in Figure 51, have more convex whorls and slightly cyrtoconoid spires, and are probably all varieties of $O$. turrita. One of the drawings of Poul Winther was named $O$. plicata by Thorson, with locality Gullmarfjorden (Fretter et al. 1986:609). This drawing looks suspiciously like 0 . turrita, which is not among the drawings in Thorson's collection. I suspect that this naming was out of respect for Ankel, who in 1949 and 1959 mentioned O. plicata as a very common ectoparasite of Pomatoceros in Gullmar-fjorden. Ankel did not mention $O$. turrita, which previously had been reported as common both in the plankton and the benthos at Kristineberg (Thorson 1946). Due to this possible misidentification, I think all records from southern Scandinavia need reaffirmation. Until further material is available, this species must be treated as a very doubtful member of the Norwegian fauna.

\section{Odostomia striolata Forbes \& Hanley, 1850-51 Figures 52-55}

Odostomia striolata, Alder - Forbes \& Hanley 1850-51:267

Odostomia striolata Forbes \& Hanley - van Aartsen et al. 1984; 

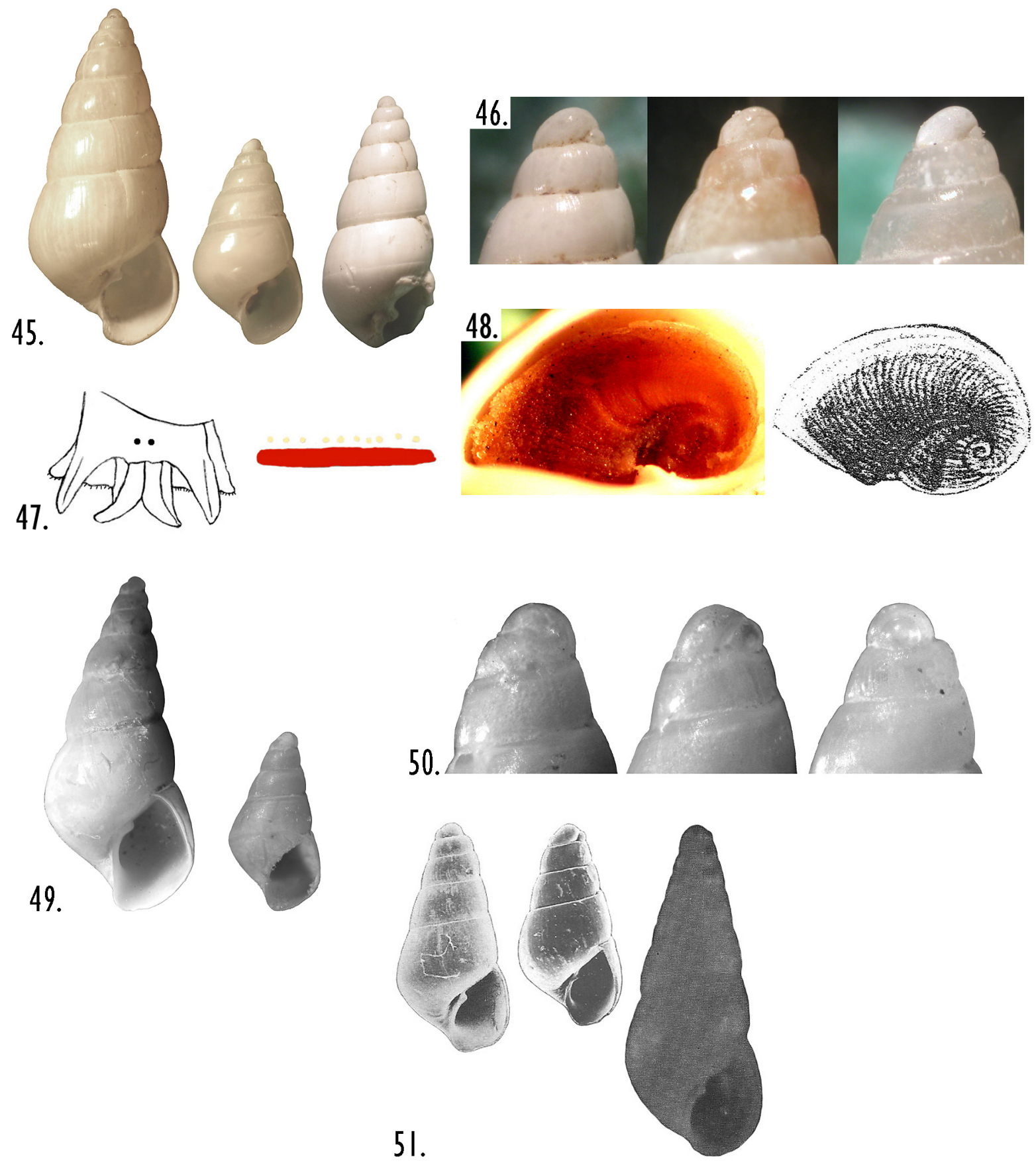

Figure 45. Odostomia conoidea. At left two specimens from Lamholmen $\mathrm{W}$ of Gjerdingen (Nord-Trøndelag), $64^{\circ} 57.5^{\prime} \mathrm{N}, 11^{\circ} 25^{\prime} \mathrm{E}, 80-30 \mathrm{~m}$, 4.65 and $2.85 \mathrm{~mm}$ (T 69077). At right a shell from Håøya, Grimstad (Aust-Agder), 58¹8’ N, 8³6.5’E, $60 \mathrm{~m}$ (G 115-71).

Figure 46. Odostomia conoidea. Three protoconchs.

Figure 47. Odostomia conoidea, head-foot complex and pigmented mantle organ (not to scale).

Figure 48. Odostomia conoidea. Operculum, two illustrations. Photo from operculum in situ within aperture (left) and copied from G.O. Sars (1878) (right).

Figure 49. Odostomia conspicua. A specimen from SE of Portør, Telemark, 58 $47^{\prime} \mathrm{N}, 09^{\circ} 29^{\prime} \mathrm{E}, 60 \mathrm{~m}$ (S 17-88) (left) and one from between

Store and Lille Torungen, Aust-Agder, 58 $24^{\prime} \mathrm{N}, 08^{\circ} 47.5^{\prime} \mathrm{E}, 70 \mathrm{~m}$ (S 66-88), 4.6 and $2.5 \mathrm{~mm}$ respectively.

Figure 50. Odostomia conspicua, protoconch of the specimen from between Store and Lille Torungen. (Cf. Figure 55).

Figure 51. Odostomia plicata. Three illustrations from the literature. From left: a SEM-photo of a specimen $1.7 \mathrm{~mm}$ long from van Aartsen et al. (1984), one (size not given) from Fretter et al. (1986), and a LM photo of a specimen $2.4 \mathrm{~mm}$ long from van Aartsen (1987). 
van Aartsen 1987; Seaward 1990; Smith \& Heppel 1991; Peñas et al. 1996; Høisæter 2009

Odostomia turrita var. striolata (Alder) - Jeffreys 1867; Marshall 1900

Odostomia monterosatoi Bucquoy, Dautzenberg, \& Dollfus, 1883:167

Odostomia eulimoides Hanley - Høisæter 1986 (in part)

Brachystomia eulimoides (Hanley) - Høisæter 1989

Ptychostomon turritum var. striolatum - Kobelt 1903

Type material: HMAC (Hancock Museum, Alder coll.) (see van Aartsen 1987:27)

Type locality: Northumberland, Great Britain.

Material seen: Norway - Skagerrak, 8 spms; Hordaland, 16 580 spms; Møre og Romsdal 3 spms, 1 sh.

Diagnosis: Shell: Max size $3.3 \mathrm{~mm}$. Convex whorls with dense microscopical striation. Protoconch angle $130^{\circ}$ $140^{\circ}$ (type B), 'nucleus' almost completely concealed, (see postlarvae, Figure 54). Soft parts: Foot short and wide. Mentum inconspicuous. Tentacles short and wide, somewhat pointed, no tentacular pads. Eyes fairly large and not particularly close together (Figure 53 top). The pigmented mantle organ (Figure 53 bottom) shows a linear row of alternating light red and yellow spots, with a series of bluish white spots above. Operculum: (Figure 55) of the Odostomia s.s. form but with an opercular 'anchor' a little smaller than e.g. the one in O. turrita (cf. Figure 62).

Biology: Of the seven species of pyramidellids found coexisting on Pomatoceros at two localities in the Espegrand area (Høisæter 1989), O. striolata (as Brachystomia eulimoides) was by far the most abundant. Whenever Pomatoceros was absent from a sample, so was $O$. striolata. During the years from 1963 to 1969 it was twice as abundant as O. turrita, also a typical Pomatoceros 'inhabitant'.

Distribution: In Norway very abundant in the Espegrend area. In the rest of Norway only found in a few samples the Skagerrak region and from Møre og Romsdal. The northernmost of these is from Frænafjorden $\left(62^{\circ} 50^{\circ} \mathrm{N}, 62-50 \mathrm{~m}\right.$, sand, two specimens). Outside Norway it is known from the British Isles and Ireland (Marshall 1900), Madeira and the Canary Isles (van Aartsen et al. 1998) and the western Mediterranean (Peñas et al. 1996).

Remarks: The specimen at left in Figure 52 is almost indistinguishable from the photograph of the holotype in van Aartsen (1987) (see van Aartsen et al. 1984 and van Aartsen 1987). The species has the general habitus of $O$. turrita but is easily distinguished by the partly concealed protoconch (type B) and when alive, the characteristic red and yellow pigmented mantle organ, clearly visible through the shell. The 'opercular 'anchor' is clearly of the 'Odostomia' type although somewhat less developed than for e.g. O. turrita. In the key to Odostomia in van Aartsen (1987), it is keyed out as 'usually with pronounced spiral striature'. This spiral sculpture is not at all prominent in my material. Jeffreys (1867) united this species with $O$. turrita, as he thought he found intermediate forms that might belong to one or the other. The species was re-introduced by van Aartsen et al. (1984). In the years 1965-1968 it was by far the commonest pyramidellid in the Espegrand area.

Odostomia turgida G.O. Sars, 1878 Figures 56-57

Odostomia turgida, n. - G.O. Sars 1878:202

Odostomia turgida G.O. Sars - Norman 1902; Høisæter 1986

Odostomia cf. turgida G.O. Sars - Høisæter 2009

Ptychostomon turgidum (G.O. Sars) - Kobelt 1903

Odostomia unidentata (Montagu) - van Aartsen 1987

Odostomia unidentata var. turgida G.O. Sars - Smith \& Heppell 1991

\section{Type material: NHMO D1082}

Type locality: Lofoten, northern Norway, ca. 120-130 m.

Material seen: Norway - Nordland, 6 shs (+ photograph of holotype).

Diagnosis: Shell: Most easily recognized on the rapid expansion of the diameter of the first few teleoconch whorls. The helicoid protoconch is large and protruding and completely exposed (Figure 57). Soft parts: Not known. Operculum: Not known.

Biology: Not known.

Distribution: A few shells from Lofoten (around $68^{\circ} \mathrm{N}$ ) (G.O. Sars 1878). In my material six shells from between $66^{\circ}$ and $67^{\circ} \mathrm{N}$. Not known outside Norway.

Remarks: G.O. Sars described O. turgida from a few empty shells from $90-110 \mathrm{~m}$ in Lofoten, and mentioned that Jeffreys had some material of the same species from Finnmark donated by MacAndrews and Barrett (according to usage at the time, 1856, 'Finmark' might be anywhere in northern Norway). He listed the max. length as $3.2 \mathrm{~mm}$, versus 5.0 for $O$. unidentata. A photograph of the holotype was kindly made at my request at the Natural History Museum, University of Oslo (Figure 56 at left). The condition of the shell is not good, but it may be deduced that the whorls of the spire are rather convex with a deeper suture than in $O$. unidentata and the body whorl is almost globose. Van Aartsen (1987) after having inspected the holotype considered that $O$. turgida was a synonym of $O$. unidentata. However, in my material some shells from northern Norway have a large, protruding protoconch and are definitely different from 0 . unidentata (cf. Figure 57 with Figure 66), and also different from O. conspicua, (which in Norway seems to be confined to the Skagerrak coast). These shells are most probably conspecific with $O$. turgida, although the body whorl is more keeled in my shells. The aperture is also somewhat more squarish in my shells. These differences might be due to size differences. Best distinguished from $O$. unidentata by the apical angle, the completely exposed protruding protoconch, and in well preserved shells, by the lack of three spiral striae at 
the base of the protoconch (as is found in O. unidentata, Figures 65 and 66).

\section{Odostomia turrita Hanley, 1844}

Figures 58-62

Odostomia turrita - Hanley 1844:18

Odostomia turrita Hanley - Alder 1848; Jeffreys 1859, 1867, 1870; Friele 1874; G.O. Sars 1878; Norman 1879; Collin 1880, 1884; Jeffreys 1884; Petersen 1888; Marshall 1900; Norman 1902; Dautzenberg \& Fischer 1912; Winckworth 1932; van Aartsen \& al. 1984; Fretter et al. 1986; Høisæter 1986; van Aartsen 1987; Høisæter 1989; Smith \& Heppell 1991; Schander 1995; Peñas et al. 1996; Schander et al. 2003; Høisæter 2009

Ptychostomon turritum Hanley - Kobelt 1903

Odostomia unidentata var. turrita? Hanley - Forbes \& Hanley 1850-51

Odostomia plicata ? (Montagu) - Friele 1874 (see Norman 1879)

Odostomia plicata (Montagu) - Ankel 1959; Maas 1965; Fretter et al. 1986 (in part) (not O. plicata (Montagu))

Chemnitzia acuta Jeffreys - Clark 1855 (in part)

Type material: A single battered specimen from Guernsey (Jeffreys 1848).

Type locality: Herm, near Guernsey, Channel Islands (Forbes \& Hanley 1850-51).

Material seen: Norway - Skagerrak, 120 spms; Hordaland, 8011 spms; Møre og Romsdal 4 spms, at least 2 shs; NordTrøndelag, 15 spms at least 4 shs; Nordland, 101 spms, 14 shs; Troms, 1 sh.

Diagnosis: Shell: The smallest of the six species of Odostomia s.s. in the Norwegian fauna, rarely more than $2.5 \mathrm{~mm}$ long (max. length measured out of the roughly 8000 specimens was $3.1 \mathrm{~mm}$, and less than $10 \%$ of all were more than $2 \mathrm{~mm}$ long). Shell shape variable, but usually a rather narrow cone. As opposed to $O$. plicata with distinctly prosocline growth lines. Protoconch at c. $90^{\circ}$ to shell axis, nucleus clearly visible. Soft parts: The foot and tentacles (Figure 59) are comparatively long and flexible as compared to the other species of Odostomia s.s. observed. No tentacular pads. Pigmented mantle organ (Figures 59 and 61) is 'sealing-wax' red, easily visible through the shell. The oblong, bright red gland is subdivided by one to several black 'belts'. With the proviso that not all species in Odostomia s.s. have been observed alive, this colouration is 'diagnostic' for O. turrita. Operculum: (Figure 62) with opercular 'anchor' smaller than all other members of Odostomia s.s. observed, except $O$. striolata.

Biology: This is yet another species predominantly, but not exclusively, associated with Pomatoceros. Its feeding biology has been described in detail by Ankel (1959) (as. O. plicata). Sneli (1972) reported it as feeding on the gills of Homarus, but as remarked by Schander (1995) it is more likely that the single specimen observed was actually feeding on a Pomatoceros specimen on the Homarus shell.

Distribution: Whole coast of Norway, excluding east Finnmark, G.O. Sars 1878. Only empty shells found N of $68^{\circ} \mathrm{N}$, however. Norman (1902), based on literature records, included $O$. turrita in his list from east Finnmark. Not mentioned in Friele \& Grieg (1901). In my material more than 8000 specimens and around 500 shells. The northernmost shell from Andfjorden, east of Andøya (69 $19^{\circ} \mathrm{N}, 65-80 \mathrm{~m}$, coarse shell gravel). The northernmost specimen from Glomfjorden $\left(66^{\circ} 49^{\prime} \mathrm{N}, 120-60\right.$ $\mathrm{m}$, stones). Otherwise found in all sectors southwards, but whereas $O$. unidentata is increasing in abundance northwards, $O$. turrita is decreasing. Ten samples with 34 specimens in the material from Skagerrak. Outside Norway it is recorded from the Mediterranean (Peñas et al. 1996; Cachia et al. 2001), Mauritania and the Canary Islands (van Aartsen et al. 1998) to most coasts of the British Isles (Fretter et al. 1986), Ireland, Swedish west coast, the Faroes and Iceland (Schander 1995), and inner Danish waters (the Sound, Thorson 1946). Recently (Nekhaev 2011) reported it from the Russian Barents Sea coast near Murmansk.

Remarks: A most variable shell, usually identified by its small size. Easy to identify when alive because of the pigmented mantle organ and the prosocline growth lines. Weak spiral strations may occur, as in many other species of Odostomia. Misidentified by Ankel (1959) and Maas (1965) as O. plicata (See Remarks under $O$. plicata above).

\section{Odostomia unidentata (Montagu, 1803)} Figures 63-67

\section{Turbo unidentatus - Montagu 1803:324}

Odostomia unidentata (Montagu) - Alder 1848; Forbes \& Hanley 1850-51; Jeffreys 1867; Jeffreys 1870; M. Sars 1870; Friele 1874; G.O. Sars 1878; Norman 1879; Collin 1884; Jeffreys 1884; Schneider 1886; Petersen 1888; Norman 1892; Appellöf 1897; Grieg 1897; Marshall 1900; Friele \& Grieg 1901; Norman 1902; Grieg 1913, 1914; Bardarson 1920; Thiele 1928; Winckworth 1932; Fretter et al. 1986; Høisæter 1986; van Aartsen 1987; Graham 1988; Høisæter 1989; Smith \& Heppell 1991; Schander 1995; Peñas et al. 1996; Høisæter 2009

Chemnitzia unidentata (Montagu) - Clark 1855

Ptychostomon unidentatum (Montagu) - Kobelt 1903

Odontostomia unidentata (Montagu) - Dautzenberg \& Fischer 1925

Turbonilla albella Lovén, 1847

Odostomia unidentata var. albella (Lovén) - Smith \& Heppell 1991

Odostomia plicata (Montagu) - M. Sars 1859 (not O. plicata (Montagu, 1803))

Type material: Not known. 

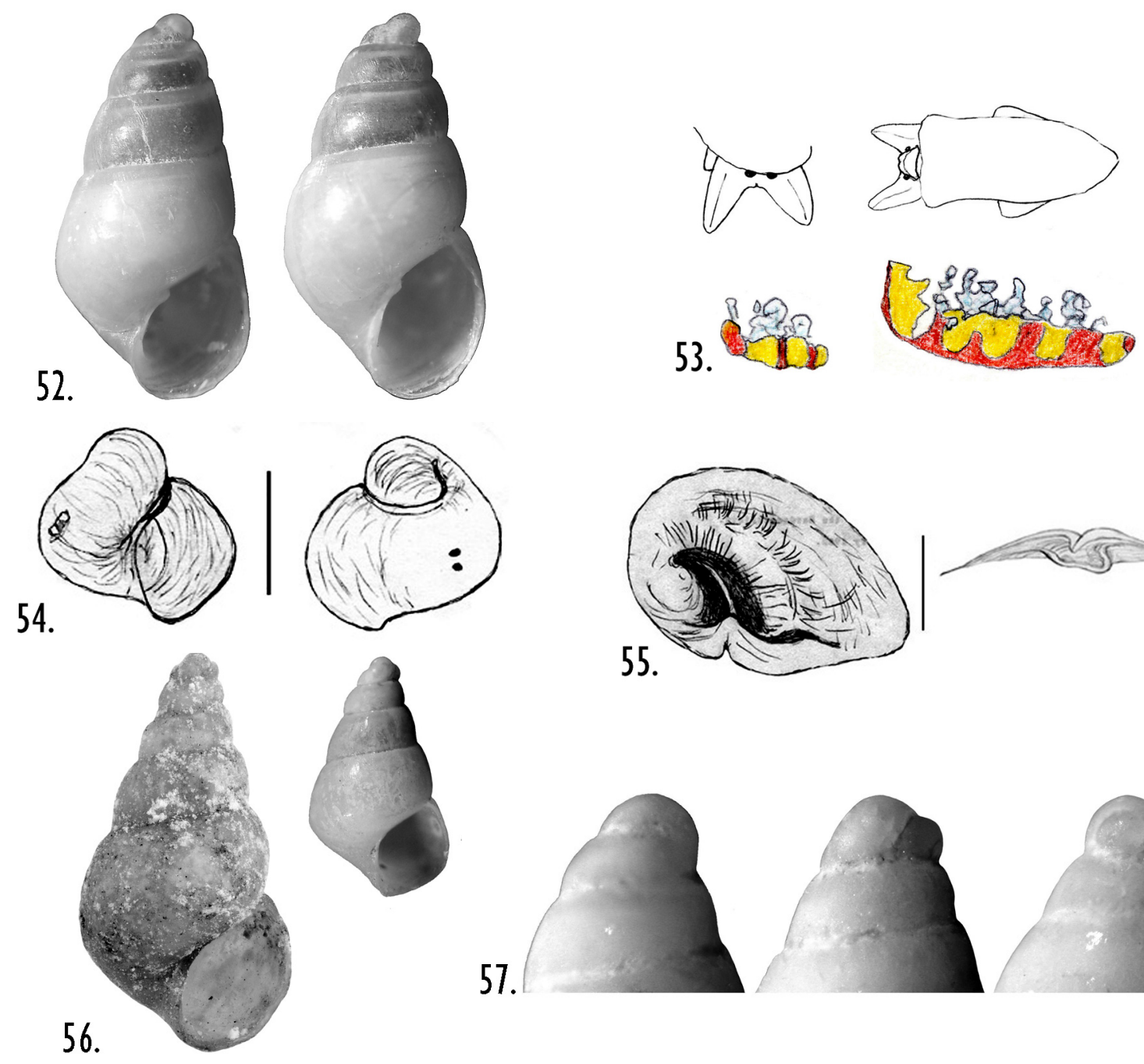

57.
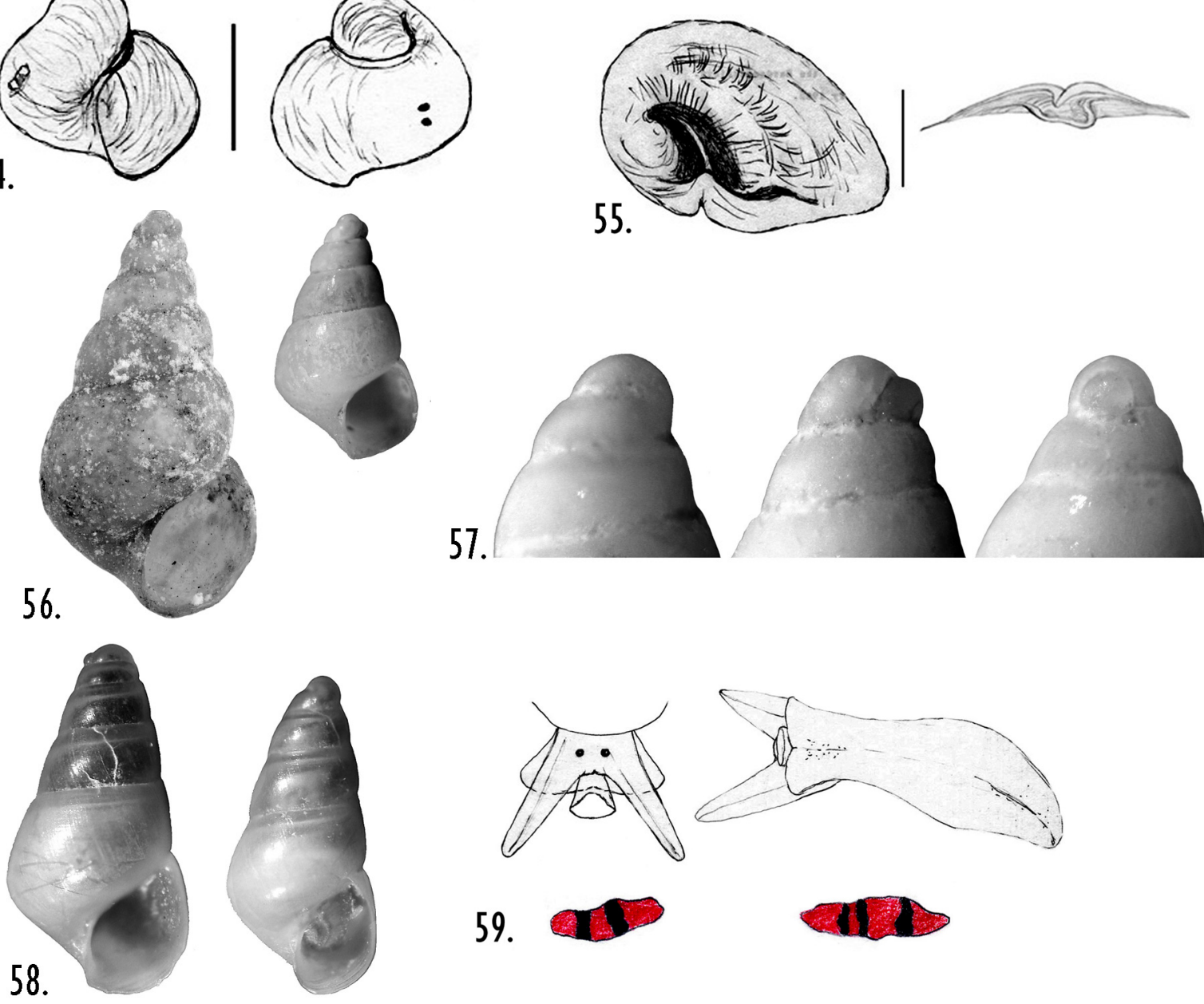

\section{9.}

Figure 52. Odostomia striolata. Two specimens from Pomatoceros-reef, Hillersholmen, Raunefjorden, $60^{\circ} 17.9^{\prime} \mathrm{N}, 05^{\circ} 10.8^{\prime}, 5-8 \mathrm{~m}$, (ZMBN $82571)$ both $2.5 \mathrm{~mm}$ long.

Figure 53. Odostomia striolata, head-foot complex and pigmented mantle organ(not to scale).

Figure 54. Odostomia striolata, juvenile. Scale bar $=300 \mu \mathrm{m}$.

Figure 55. Odostomia striolata, operculum, two views. Scale bar $=200 \mu \mathrm{m}$.

Figure 56. Odostomia cf. turgida, Holotype of Odostomia turgida (NHMO D1082, $3.2 \mathrm{~mm}$ at left) together with a specimen from Femrissund

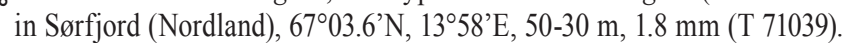

Figure 57. Odostomia cf. turgida, protoconch of the specimen at right in Figure 54.

Figure 58. Odostomia turrita. Two specimens from Pomatoceros-reef, Hillersholmen, Raunefjorden, $60^{\circ} 17.8^{\prime} \mathrm{N}, 05^{\circ} 11.1^{\prime}$, c. $8 \mathrm{~m}, 1.95$ and $1.8 \mathrm{~mm}$ (ZMBN 82698).

Figure 59. Odostomia turrita, head-foot complex and pigmented mantle organ (not to scale). 
60.
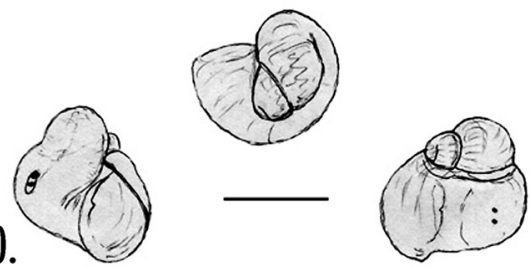

62.
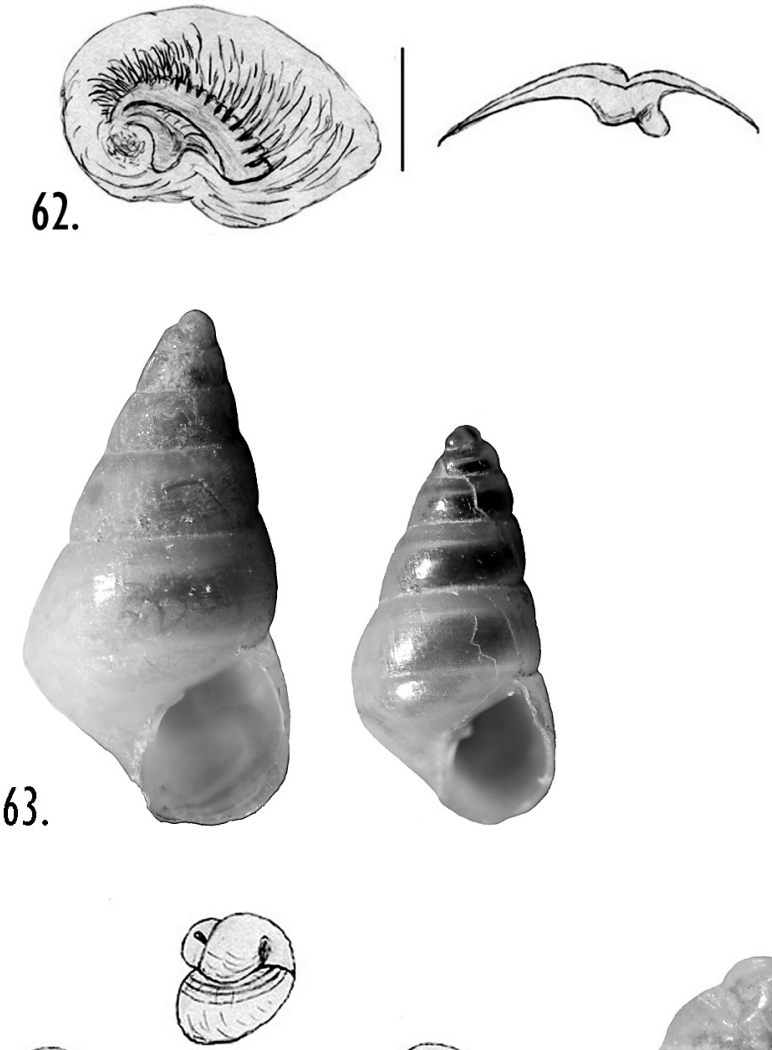

65.
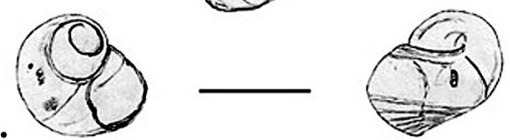

66.
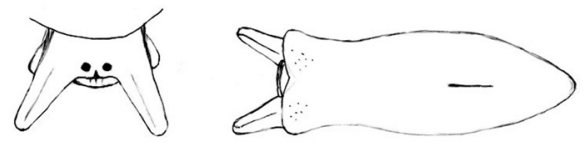

64.
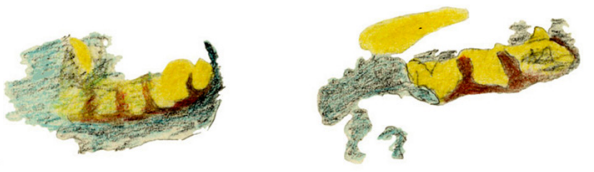

61.
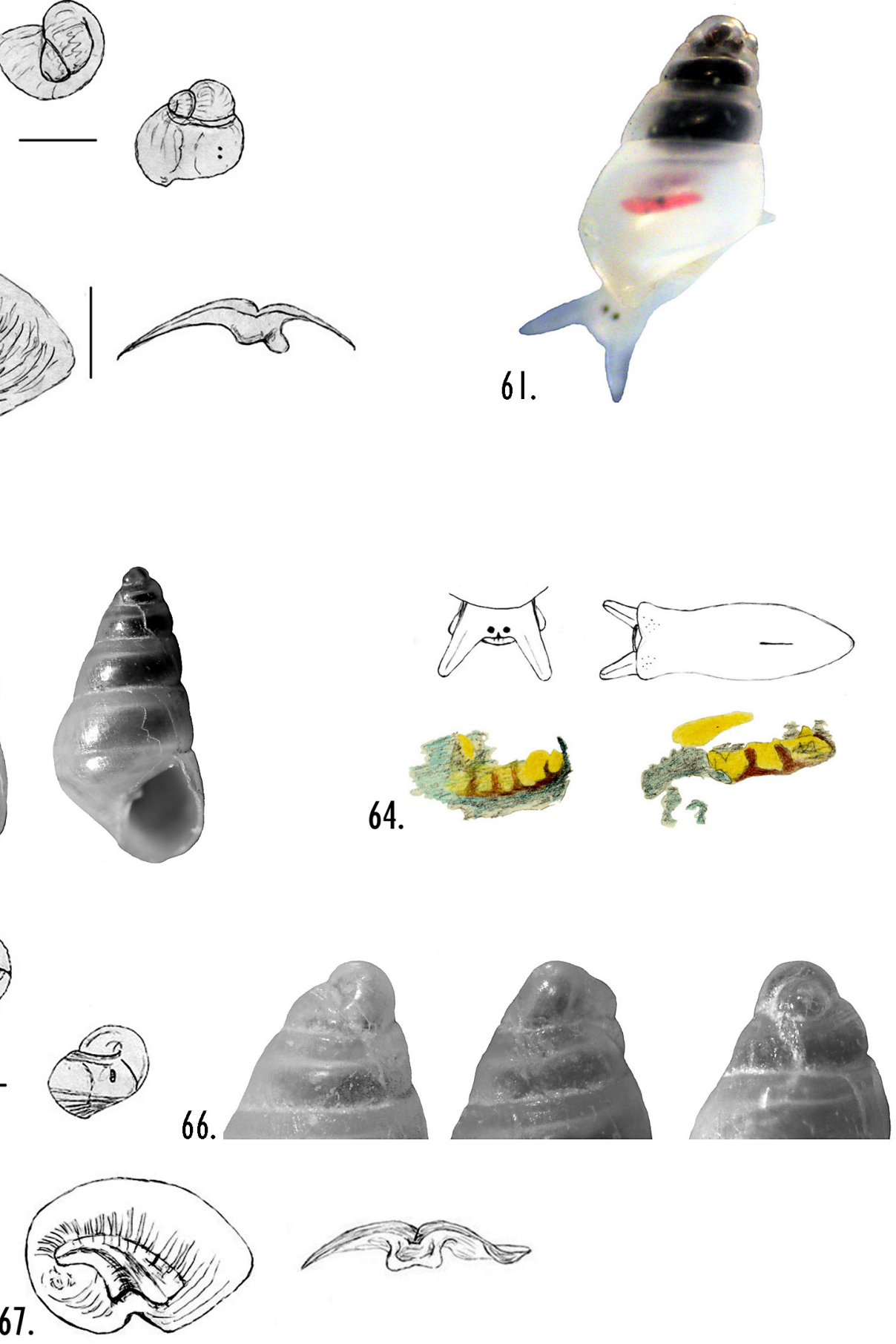

Figure 60. Odostomia turrita, juvenile. Scale bar $=300 \mu \mathrm{m}$.

Figure 61. Odostomia turrita, specimen photographed alive.

Figure 62. Odostomia turrita, operculum, two views. Scale bar $=200 \mu \mathrm{m}$.

Figure 63. Odostomia unidentata Two specimens from Pomatoceros-reef, Hillersholmen, Raunefjorden, $60^{\circ} 17.8^{`} \mathrm{~N}, 05^{\circ} 11.1^{\prime}, 7-9 \mathrm{~m}, 3.05$ and $2.4 \mathrm{~mm}$ (ZMBN 82780).

Figure 64. Odostomia unidentata, head-foot complex and pigmented mantle organ. Not to scale.

Figure 65. Odostomia unidentata, juvenile. Scale bar $=300 \mu \mathrm{m}$.

Figure 66. Odostomia unidentata. Protoconch of the specimen at right in Figure 61.

Figure 67. Odostomia unidentata, operculum, two views. 
Type locality: Salcombe Bay, Devonshire, Great Britain (Peñas et al. 1996).

Material seen: Norway - Skagerrak, 23 spms; Hordaland, 3287 spms; Møre og Romsdal 6 spms; Nord-Trøndelag, 15 spms; Nordland, 163 spms, 14 shs; Troms, 3 spms.

Diagnosis: Shell: Large (to $5 \mathrm{~mm}$, G.O. Sars 1878), broadly conical with flatsided whorls. Typically (but not always) with keeled body whorl. No umbilicus. Protoconch large and $90^{\circ}$ with shell axis. Postlarvae have three spiral striae at the top of of the first teleoconch whorl, and several more on its base (Figure 65). These striae are also visible on well preserved adult shells. Soft parts: Eyes large and moderately close together. Tentacles wide and fairly short, no tentacular pads. Mentum short and inconspicuous. Foot fairly wide ending in a blunt point (Figure 64 top). Pigmented mantle organ (Figure 64 bottom), oblong blotches, yellow with brown 'fingers'. Bluish-gray blotches, spread over the head/foot-area. Operculum: (Figure 67) of typical 'Odostomid' type, the size of the opercular 'anchor' somewhere between that of O. acuta and O. turrita.

Biology: According to Fretter et al. (1986) often common on boulders with a good growth of Pomatoceros. Like $S$. spiralis, O. turrita and O. striolata strongly associated with Pomatoceros-reefs, at the locality at Hillersholmen, in Raunefjorden . At the locality in Knappensundet, only a handful specimens, as opposed to the thousands of $O$. striolata and $O$. turrita, were found in samples of Pomatoceros reef. Own observations in vitro indicated that young specimens of this species, and occasionally other reef-living pyramidellids, sat on the operculum of Pomatoceros, sucking out body fluids through the branchial filaments of the polychaete.

Distribution: Reported from the entire Norwegian coast, including east Finnmark by G.O. Sars (1878). In my material 3500 specimens and 650 shells. One specimen at each of three stations in the Kvæfjord/Grovfjord/Gratangen area (c. $\left.68^{\circ} 40^{\prime}-45^{\prime} \mathrm{N}\right)$. Ten samples with 46 specimens in the material from Skagerrak. Otherwise evenly distributed along the coast southwards, but slightly more abundant than $O$. turrita in all sectors. Outside Norway it is recorded from Iceland, Faroes, the Swedish west coast, all around the British Isles and Ireland, although sparingly in the southern North Sea along the Atlantic coasts of France, Spain and Portugal and also into the western part of the Mediterranean (Fretter et al. 1986, Peñas et al. 1996). Also known from the northwestern coast of Africa, Cape Verde Islands, the Canary Islands, Madeira and Selvagens archipelago (van Aartsen et al. 1998). Recently extended to the eastern Mediterranean (Öztürk et al. 2013).

Remarks: Generally regarded as the most widely distributed species of Odostomia s.s. in European waters. Might be confused with several other species, such as $O$. acuta, O. turrita, O. turgida, O. conspicua and O. umbilicaris, all with protoconchs of type A, but the protoconch (Figure 66) is larger and with first whorl relatively large compared to the next whorl. A combination of size, presence of keel on body whorl, lack of umbilicus, lead-gray blotches and characteristic pigmented mantle organ are diagnostic for this species.

\section{Jordaniella Chaster, 1898}

Type species, by subsequent designation: Turbo nivosus Montagu, 1803; designated by Chaster (1901:8). Britain.

= Jordanula Chaster, 1901. Unnecessary replacement name.

Pyramidellids with small $(<4.5 \mathrm{~mm}$ long), nearly cylindrical shells of no more than six whorls. Sculpture consisting of spiral lirae and growth lines. Aperture egg-shaped to oval. Columellar fold retracted and low, but always present. Protoconch small and inverted.

The type species was included in the molecular analysis of pyramidellids by Schander et al. (2003), who concluded that the use of Jordaniella as a genus is justified.

\section{Jordaniella nivosa (Montagu, 1803)} Figures 68-69

\section{Turbo nivosus - Montagu 1803:326}

Chemnitzia nivosa (Montagu) - Clark 1855

Odostomia nivosa (Montagu) - Jeffreys 1867; Marshall 1899, 1918; van Aartsen \& al. 1984; Høisæter 1986

Odostomia (Jordaniella) nivosa (Montagu) - Winckworth 1932; van Aartsen 1987

Jordaniella nivosa (Montagu) - Fretter et al. 1986; Graham 1988; Smith \& Heppell 1991; Schander et al. 2003

Chrysallida nivosa (Montagu) - Peñas et al. 1996; Høisæter 2009

Ptychostomon (Ondina) nivosum (Montagu) - Kobelt 1903

Odostomia cylindrica Alder, 1844:327 - Forbes \& Hanley 185051; Jeffreys 1859

Type material: BMNH (Montagu's type, with "nivosus" in his handwriting, is still preserved in the British Museum, Jeffreys 1867:117).

Type locality: Devonshire, Great Britain (Peñas et al. 1996)

Material seen: Norway - Hordaland, 19 spms.

Diagnosis: Shell: (Figure 68) small (max. $2.1 \mathrm{~mm}$ ), almost cylindrical. Suture channeled. Sculpture restricted to one or two spiral grooves, just above the suture, in addition to rather coarse prosocline growth lines. Protoconch intorted (type B). Aperture oval. Columellar tooth weak and retracted. Soft parts: Most specimens with dark (chocolate brown) digestive gland, filling all whorls, except the body whorl. Some specimens with grayish, greatly diminished digestive gland. Colour of alcohol conserved animal, grayish yellow. Eyes distinct, fairly far apart (distance between eyes double of eye diameter). Operculum: Thin, yellowish, translucent, elongated, slightly kidney-shaped. No internal ridge visible on operculum in situ. 
Biology: Not known, but in this investigation only found on the stipes of Laminaria hyperborea (with much epifauna) in a semiexposed locality, 1 to $3 \mathrm{~m}$ depth.

Distribution: Not previously reported from Norway. In my material 19 specimens from a rather exposed locality near Lyroddane outside Sotra $\left(60^{\circ} 10^{\prime} \mathrm{N}\right)$ in 1992 . Outside Norway it is recently reported from Læsø, Kattegat (Olesen 2005), but not yet recorded from Sweden. It is further recorded from the Scottish North Sea coast (McKay \& Smith 1979), Shetland, the outer Hebrides and the Scottish and British west coast, western Ireland and the south coast of the British Isles and the Channel Isles (Jeffreys 1867). Found also further south on the European Atlantic coast and occurring abundantly in the Strait of Gibraltar, but not in the western Mediterranean proper (van Aartsen et al. 1984, Peñas et al. 1996).

Remarks: Van Aartsen(1987) placed this species in Odostomia, but the molecular analyses of Schander et al. (2003) suggested that $J$. nivosa is closer related to Liostomia and Parthenina, and only distantly related to Odostomia s.s.

\section{Jordaniella truncatula (Jeffreys, 1850)} Figure 70

Odostomia truncatula Jeffreys, 1850:109

Odostomia truncatula Jeffreys - Marshall 1899, 1918; Warén 1980

Odostomia (Odostomia) truncatula Jeffreys - van Aartsen et al. 1998

Chrysallida truncatula (Jeffreys) - Høisæter 2009

Odostomia (Jordaniella) truncatula Jeffreys - Winckworth 1932; van Aartsen 1987

Odostomia trunculata Jeffreys - Rodriguez-Babio \& ThiriotQuiévreux 1974

Jordaniella truncatula (Jeffreys) - Fretter et al. 1986; Graham 1988; Smith \& Heppell 1991

Type material: Lectotype (from 32 syntypes, USNM 132017) chosen by van Aartsen 1987, Figure 9.

Type locality: Plymouth, Great Britain.

Material seen: Norway - Skagerrak, 1 sh; England - 1 sh (ZMBN 15744).

Diagnosis: Shell: Tall and narrow, to $4.7 \mathrm{~mm}$. With an oblique, blunt apex. The whole surface with rather shallow and delicate spiral ridges crossed by exaggerated growth lines. The growth lines are especially distinct near the top of each whorl. Suture deep and channeled. See further Fretter et al. 1986.

Biology: Not known.

Distribution: Not previously reported from Norway, and is included here on the basis of a single brittle and partly broken shell from just south of Grimstad (G 115-71 - 58¹8’ N, 60 m, shell sand). Outside Norway it is rare everywhere, and recorded from the southwestern coast of the British Isles and the French coast south to the Bay of Biscay (Fretter et al. 1986). It is recently reported from Cape Verde Islands by van Aartsen et al. (1998).

\section{Ondina de Folin, 1870}

Type species, by subsequent designation: Ondina semiornata de Folin, 1872 [= Ondina warreni (Thompson, 1845)]; designated by van Aartsen (1984:134). Atlantic coast of France.

Synonyms: Auriculina J.E. Gray, 1847 not Grateloup, 1838.

Evalea auct., not A. Adams, 1860.

Menestho Møller, 1842 (in part).

Pyramidellids with small ( $<5.5 \mathrm{~mm}$ long), oblong-ovate to rather conical shells, of not more than six whorls. Sculpture none, or fine to moderately strong spiral lirations. Body whorl rather long and dominating. Growth lines opisthocline. Aperture mostly oblong, regularly rounded below, and acuteangled above. Columellar tooth may be absent, if present it is retracted and inconspicuous. Protoconch medium-sized to small, intorted so that usually only its base is visible. Operculum without an 'anchor' or indentation, of a more or less regular outline and with a distinct though small excentric spire. Eyes very close together.

Ondina is here used for the group of European pyramidellids which is named Evalea A. Adams, 1860 in e.g. Fretter et al. 1986 and Graham 1988. Originally this group was named Auriculina Gray, 1847, with Odostomia obliqua Alder, 1844 as type species. This name was, however, preoccupied by Auriculina Grateloup, 1838. Thiele (1929) in splitting the large and heterogeneous "genus" Odostomia (sensu Dall \& Bartsch, 1904) into smaller units, chose Menestho Møller, 1842 as the oldest of the sections of Dall \& Bartsch with only spiral sculpture. This name was accepted by Winckworth (1932) (with Evalea as a subgenus) and, following him, Høisæter (1986). The type species of Menestho is Turbo albulus Fabricius, 1780, an arctic species with a heavy shell and strong spiral sculpture. I agree with van Aartsen (1984, 1987), Smith \& Heppell (1991) and Warén (1991) that this species has little in common with the thin-shelled, oval species from Europe. According to van Aartsen (1987), Evalea, based on Odostomia (Evalea) elegans A. Adams, 1860, is neither a suitable genus for this group of European species. The type species is described from Japan, it has a distinct, if small, columellar tooth, and has rather distinct spiral grooves. Kobelt (1903) was apparently the first to use Ondina for this group of European pyramidellids, although he excluded the smooth ones. I follow van Aartsen (1987) in adopting Ondina de Folin, 1870, with Ondina semiornata de Folin, 1872 as type species, for the European species formerly included in Auriculina J.E. Gray, 1847.

The European members of Ondina have been revised by van Aartsen (1987), and the Scandinavian ones by Warén (1991). Warén included five species in the Scandinavian fauna. 
He did not mention the record of Jeffreys (1870) of $O$. warreni from Oslofjorden, however, and he disagreed with van Aartsen's opinion of $O$. perezi as a taxon specifically distinct from O. diaphana. By accepting both of these as species found in Norwegian waters, the number of species was increased to seven in Høisæter (2009). A final complication not adressed by neither Warén nor Høisæter (2009) is the taxonomic status of G.O. Sars' (1878) variety, nobilis of O. divisa.

As will be evident from the discussion below the variability of the recognized species within this group is large, and the number of shell characters is limited, so correct delimitation of species based solely on shell characters is rather contentious. The species recognized from northeast Atlantic waters do either have smooth shells, or are variously decorated with incised spirals on part of, or the whole of the whorls. The density and distribution of these spirals is usually accepted as the main distinguishing character for the different species, but the variability of this character is high. The species described as being smooth sometimes have weak spirals, while the spirally striated ones are said to have smooth varieties (e.g. Marshall 1900). The species in the 'smooth' group are $O$. diaphana, $O$. perezi, $O$. obliqua and $O$. normani. Those in the group with spiral sculpture are $O$. divisa, O. coarctata and $O$. warreni. Species with spirally incised shells from Norwegian waters may be divided, based on the records we have so far, into northern forms $(O$. coarctata and $O$. divisa forma nobilis) and southern forms (O. warreni), with $O$. divisa being the only species common to both the northern and southern region.

The key below is, due to the extreme variability in members of this group, especially preliminary, and should be followed up with close scrutiny of photographs and diagnoses.

Key to the species of Ondina, based on shell morphology

1a. Shell with sculpture of spiral lines $\ldots 2$

1b. Shell smooth .5

2a. Spirals confined to lower part of the whorls . .3

$2 b$. Spirals covering more or less the whole shell .4

3a. Shell not exceeding $3.5 \mathrm{~mm}$, yellowish colour Ondina divisa

3b. Shell narrow conical with somewhat flattened whorls, reddish colour, from the North Sea Ondina divisa cf. rubra

3c. Shell not exceeding $4.6 \mathrm{~mm}$, broadly conical, yellowish colour, northern form Ondina divisa forma nobilis

4a. Shell with fine spirals covering the whole shell, northern species Ondina coarctata

4b. Shell with coarse spirals on lower half of the whorls, and very dense, fine spirals above, southern species Ondina warreni 5a. Protoconch planorboid almost disjunct, body whorl dominating . Ondina obliqua

5b. Protoconch intorted, type B 6

6a. Convex whorls, rather deep suture Ondina normani

6b. Flattish whorls, shallow suture 7

7a. Shell narrow, shiny, no umbilicus Ondina diaphana

7b. Shell like O. diaphana, but flatter whorls with dull surface Ondina perezi

\section{Ondina coarctata (G.O. Sars, 1878)}

Figure 71

Auriculina coarctata G.O. Sars, 1878:205

Auriculina coarctata G.O. Sars - Friele \& Grieg 1901

Ptychostomon (Ondina) coarctata (G.O. Sars) - Kobelt 1903

Menestho (Evalea) coarctata (G.O. Sars) - Høisæter 1986

Ondina coarctata (G.O. Sars) - van Aartsen 1987; Smith \& Heppell 1991; Warén 1991; Høisæter 2009

Type material: Holotype (5.2 mm) NHMO D 1126 and two paratypes USNM 131928 and 132715.

Type locality: Hasvik, western Finnmark, northern Norway, 90-180 m.

Material seen: Norway - Nordland, 1 spm); Finnmark, Hammerfest 1 sh (ZMBN 21623) (+ Photograph of holotype NHMO D 1126).

Description: Shell: Fairly large for the genus (max. length reported $5.2 \mathrm{~mm}$ ). Shell with regular fine spirals uniformly covering the whole shell (the shells in Figure 71 are not in good enough condition to show the spiral sculpture). Protoconch small and intorted. Soft parts: Not known. Operculum: Not known.

\section{Biology: Not known.}

Distribution: So far known from three shells (type material) from Hasvik in western Finnmark $\left(70^{\circ} 30^{`} \mathrm{~N}, 90-180\right.$ m, G.O. Sars 1878) (Figure 71 left) and a shell from Hammerfest (Figure 71 right). A number of specimens in my material might belong to this species, the one illustrated in Figure 71 (middle) from Nordfjorden (in Melfjorden, Rødøy in Nordland, 66 $34^{\prime} \mathrm{N}$, $15-11 \mathrm{~m})$ is the one most similar to the holotype. Outside Norway it is reported from western Iceland $\left(64^{\circ} 21^{\prime} \mathrm{N}, 12^{\circ} 43.5^{\prime}\right.$ W, $162 \mathrm{~m}$ ) with a single specimen and one shell (Warén 1991). Whether his specimen from Iceland is conspecific with Sars' species is not at all obvious from the illustrations in van Aartsen (1987) (holotype) and Warén (1991) (specimen from Iceland) (see discussion below). If this latter specimen is disregarded, the known distribution is between $70^{\circ} 40^{\prime} \mathrm{N}$ and $66^{\circ} 34^{\prime} \mathrm{N}$ on the coast of northern Norway.

Remarks: A photograph of the holotype kindly made at my request at the Natural History Museum, University of Oslo (Figure 71 at left) reveals that the holotype is in poor shape. 
The spiral sculpture may be glimpsed in a few places, but generally it is concealed by 'fouling'. The general shape of the shell though is close enough to that of my two shells to claim the three be members of the same species. My two shells falls outside the range of variation of the other species known from northern Norway.

According to Warén (1991) O. coarctata resembles $O$. divisa but is larger, with proportionally shorter aperture, and have stronger spiral sculpture. According to van Aartsen (1987) (who had access to the holotype) O. coarctata differs from $O$. divisa by a spiral sculpture consisting of many fine spirals present over the total height of all the whorls, of the same strength throughout. G.O. Sars (1878) also describes the sculpture as dense and fine spirals covering the whole shell. (O. divisa forma nobilis should have more or less the same type of spiral sculpture according to his latin description). $O$. coarctata is distinguished from $O$. divisa by a heavier, thicker shell, larger and 'deeper' umbilicus, and smaller protoconch. An important difference from $O$. divisa is, according to G.O. Sars, the comparatively much wider body whorl. This latter character is not obvious in the SEM photo of the specimen from Iceland in Warén (1991). A character of potential importance illustrated in a SEM photo of the top whorls of the specimen from Iceland, (Warén 1991, Figure 36D) is the spiral sculpture covering the whole of the first postlarval whorl (at least eight spiral incisions). In $O$. divisa there is only a few spirals at the base of this first whorl. This character is not mentioned in either the original description nor in the brief redescription in van Aartsen (1987). I conclude that the specimen from western Iceland illustrated in Warén (1991, Figures 34F and 36D) do not belong to $O$. coarctata but to a special form of $O$. divisa, as this species appears to vary widely geographically (see below).

\section{Ondina divisa (J. Adams, 1797)}

\section{Figures $72-74$}

Turbo divisus J. Adams, 1797:254

Menestho (Evalea) divisa (J. Adams) - Winckworth 1932; Høisæter 1986

Evalea divisa (J. Adams) - Fretter et al. 1986; Graham 1988

Ondina divisa (J. Adams) - van Aartsen 1987; Warén 1991;

Smith \& Heppell 1991; Schander 1995; Peñas et al. 1996;

Schander et al. 2003; Høisæter 2009

Turbo insculptus Montagu, 1808:129

Chemnitzia insculpta (Montagu) - Clark 1855

Odostomia insculpta (Montagu) - Alder 1848; Forbes \& Hanley

1850-51; Jeffreys 1867; M. Sars 1869; Jeffreys 1870; M. Sars

1870; Friele 1874; Norman 1879; Jeffreys 1884; Marshall 1900; Bardarson 1920

Odostomia (Auriculina) insculpta (Montagu) - Collin 1880

Auriculina insculpta (Montagu) - G.O. Sars 1878; Petersen

1888; Norman 1893; Friele \& Grieg 1901

Auriculina insculpta var. nobilis G.O. Sars - G.O. Sars 1878;

\section{Schneider 1886}

Ptychostomon (Ondina) insculptum (Montagu) - Kobelt 1903

Turbonilla obliqua (Alder) - Lovén 1846a, b (not Odostomia obliqua Alder, 1844; fide Jeffreys 1867)

Odostomia (Auriculina) obliqua (Alder) - Collin 1880 (not

Odostomia obliqua Alder, 1844; fide Petersen 1888)

Type material: Neotype of Turbo divisus designated by Warén 1991 from a syntype $(2.6 \mathrm{~mm})$ of $T$. insculptus, BMNH 1896.8.6.37.

Type locality: Ilfracombe, Devon, Great Britain.

Material seen: Norway - Skagerrak, 26 spms; Hordaland, 16 spms; Møre og Romsdal 26 spms; Nord-Trøndelag, 4 spms; Nordland, 100 spms.

Diagnosis: Shell: Spiral grooves separated by broad interspaces confined to the lower half of each whorl, and to the peripheral region and basal part of the last whorl. Microscopic spiral striae are found above the grooves and also between grooves. Maximum reported size, $3.8 \mathrm{~mm}$. Soft parts: (Based on a juvenile from Liholmsrennen, Raunefjorden). A pale rustred pattern on head region. Eyes very close together. Mentum deeply cleft. Tentacles slightly curved and diverging, with tentacular pads. Foot bilobed posteriorly (Figure 74). Pigmented mantle organ orange with light yellow specs (Figure 74 bottom left). Operculum: (Figure 74 bottom right) oval, flat, no internal process or marginal notch.

Biology: Not known.

Distribution: Found all along the coast of Norway, at least north to $68^{\circ} \mathrm{N}$ (G.O. Sars 1878). In my material some 150 specimens and 200 shells from 50 stations, the northernmost are two empty (and rather eroded) shells from deep water in outer Andfjorden, (c. $\left.69^{\circ} 20^{\prime} \mathrm{N}\right)$. G.O. Sars (1878) reports a variety (var. nobilis) from Hasvik in western Finnmark $\left(70^{\circ} 30^{\prime} \mathrm{N}\right)$, which should be appreciably larger, with higher spire and deeper suture, and have much finer spiral sculpture. This is the only record from north of Lofoten, and whether it is a distinct species or only a variety is still an open question (see below). Friele \& Grieg (1901) also report a specimen from Hammerfest, 20 fathoms, without specifying a particular variety. Outside Norway known from western to southern Iceland and the Faroes (Warén 1991 and Schander 1995), the Swedish west coast and Kattegatt, the British and Irish west coasts and further south to the Bay of Biscay (Fretter et al. 1986). Not reported further south or from the Mediterranean. Peñas et al. (1996) illustrates a specimen from Santander, the Spanish coast of the Bay of Biscay.

Remarks: The narrow and rather straight-sided first postlarval whorl might be peculiar to O. divisa (cf. Figures 72 and 78). This is the commonest species of Ondina in Norwegian waters, but several morphotypes can be distinguished in my material. The possibility of several species, or at least geographical varieties, being involved cannot be rejected (cf. Figure 73 above, showing photographs of one specimen from northern Norway, one from western Norway and one from the Skagerrak region). 
68.

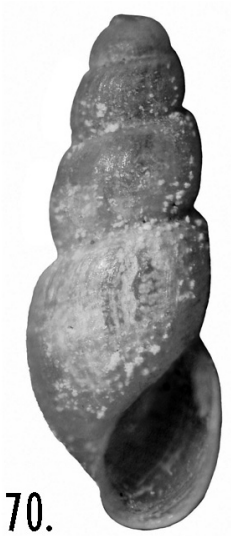

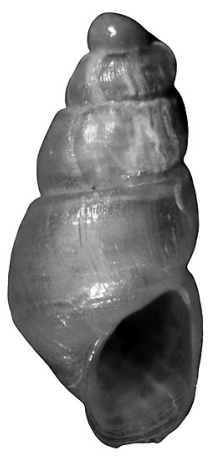

69.
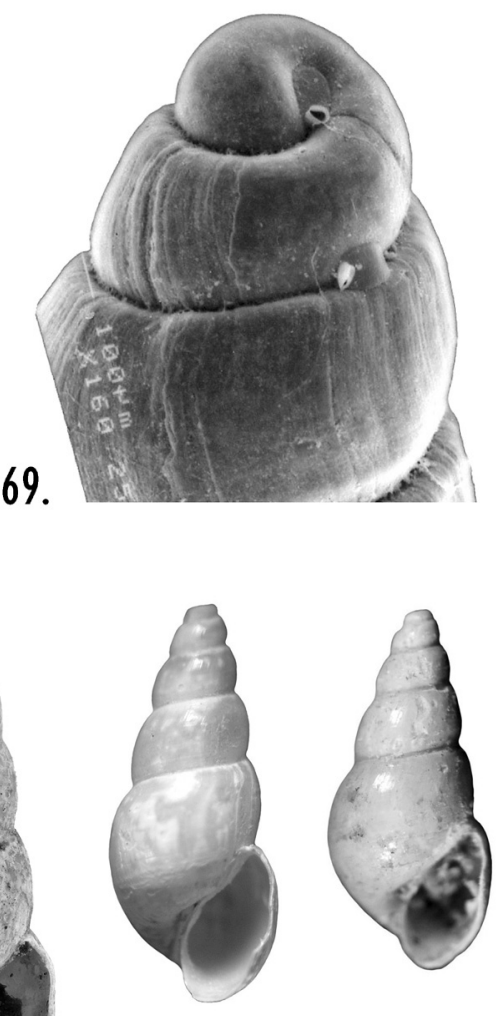

71.
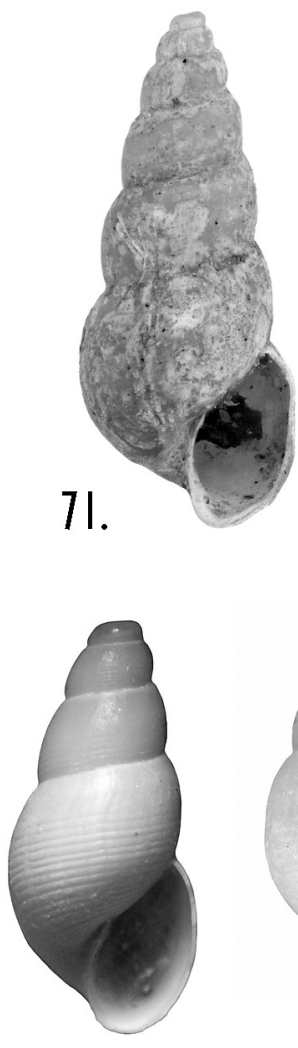
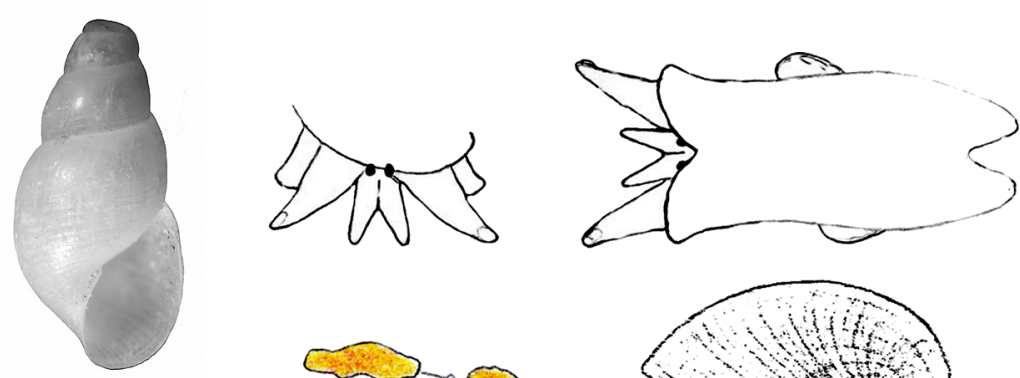

74.

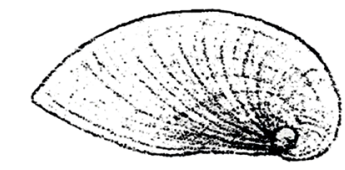

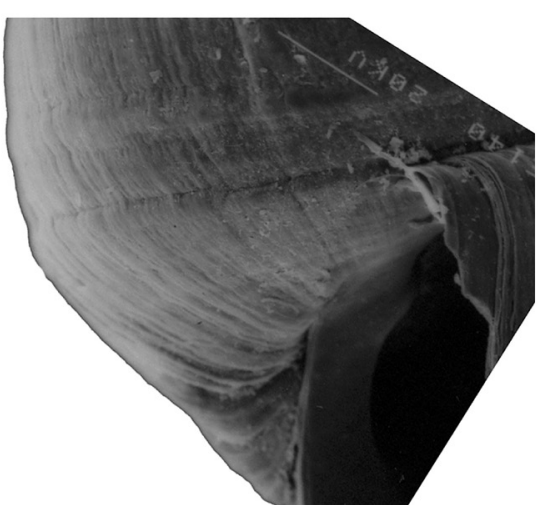

72.
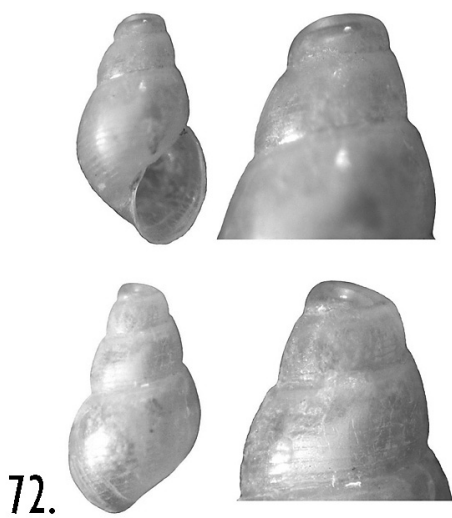
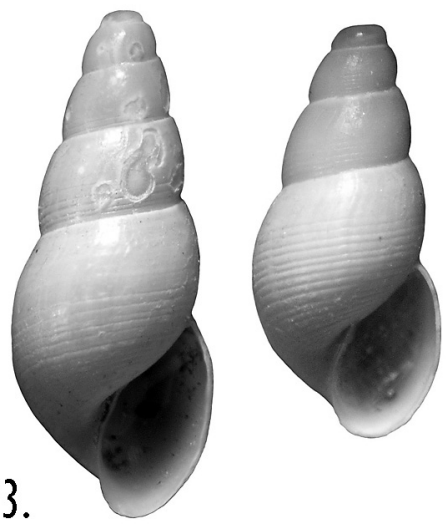

Figure 68. Jordaniella nivosa. Two specimens from Laminaria hyperborea stipes, sheltered locality at Lyroddane outside Sotra, $60^{\circ} 10^{\prime} \mathrm{N}$, 04 $59.2^{\prime}$ E, c. 2 m, 1.8 and $1.45 \mathrm{~mm}$ (F1S, 16/9 1992).

Figure 69. Jordaniella nivosa. SEM photographs of details of protoconch and spiral groove of the right specimen in Figure 66.

Figure 70. Jordaniella truncatula. A shell (2.4 mm) from England (ZMBN 15744). Friele det.

Figure 71. Ondina coarctata. From left: holotype NHMO D1126, $5.2 \mathrm{~mm}$, a specimen from Nordfjorden in Rødøy, (Nordland), $66^{\circ} 34.3^{\prime} \mathrm{N}$ 1330.5’ $\mathrm{E}, 15-11 \mathrm{~m}, 4.0 \mathrm{~mm}$ (N 15-84), and one from Hammerfest, 90-110 m (ZMBN 21623), $3.65 \mathrm{~mm}$.

Figure 72. Ondina divisa, a specimen from near Grimstad (Aust Agder), $58^{\circ} 19^{\prime} \mathrm{N}, 1.75 \mathrm{~mm}$ (G 106-71).

Figure 73. Ondina divisa. Three specimens showing geographic variation of the species. From left: Near Grimstad (Aust Agder), 58 $19^{\prime} \mathrm{N}$, $08^{\circ} 36^{\prime} \mathrm{E}, 35 \mathrm{~m}, 3.65 \mathrm{~mm}$ (G 4-79); Hoholmsundet (Nordland), 66 $04^{\circ} \mathrm{N}, 12^{\circ} 17^{\prime} \mathrm{E}, 40-35 \mathrm{~m}, 2.5 \mathrm{~mm}$ (N 3-84), and Fanafjorden NW of Korsneset, $60^{\circ} 13^{\prime} \mathrm{N}, 05^{\circ} 13.8^{\prime} \mathrm{E}, 100 \mathrm{~m}, 2.2 \mathrm{~mm}$ (ZMBN 83173).

Figure 74. Ondina divisa, head-foot complex and pigmented mantle organ, and, lower right, operculum, from G.O. Sars 1878. (Not to scale). 


\section{Ondina divisa cf. rubra}

Figure 75

This form is based on eight specimens from Oseberg oilfield at $60^{\circ} 30^{\circ} \mathrm{N}, 106 \mathrm{~m}$, on the western slope of the Norwegian Trench (and thus not strictly part of the Norwegian fauna). It is most similar to $O$. divisa, because of its sculpture of five or six strong spiral grooves above the suture with dense microscopic striae above that, and the shape and size of the protoconch.The main differences from $O$. divisa are the narrower, elongated and slightly laterally compressed, shouldered whorls (see Figure 75). O. warreni as described in Fretter et al. (1986), ("The four postlarval whorls are more tumid than in obliqua, often with a peripheral flattening, and the sutures are deep,...") is quite similar, but I could find no evidence for spiral sculpture covering all of the first postlarval whorl as, according to the literature, $O$. warreni, should have. In addition to the narrow, conical shape, the most characteristic feature of this form is the reddish colour of the soft parts, varying from deep purple to slightly reddish yellow. This might be a reflection of the individual diet, though.

\section{Ondina divisa nobilis (G.O. Sars, 1878) Figure 76-77}

\section{Auriculina insculpta var. nobilis G.O. Sars, 1878:204 \\ Odostomia insculpta var. laevissima (G.O. Sars) ? - Marshall 1893, 1900}

Type material: Syntype ZMON-D1116.

Type locality: Hasvik, western Finnmark, northern Norway.

Diagnosis: Shell: Shell large, reported to reach $4.6 \mathrm{~mm}$, conical with moderately convex whorls and fairly deep sutures. Sculpture of rather fine spiral grooves separated by broader interspaces, most distinct on lower half of each whorl but weaker grooves present also on rest of whorl. Soft parts: Not known. Operculum: Not known.

Distribution: Apparently endemic to northern Norway.

A number of specimens in my material from northern Norway do not fit the description of $O$. divisa, nor of $O$. coarctata, the only other spirally lirated Ondina known from the northern coast of Norway. The variety of $O$. divisa from Hasvik in western Finnmark which G.O. Sars (1878) called Auriculina insculpta var. nobilis (Figure 76) is similar to these specimens. This variety has not been mentioned in the literature since. A possible exception is Marshall (1893 and 1900) who introduced a 'var. laevissima G.O. Sars', a name I could not find referred to in G.O. Sars (1878). The term 'laevissima' is however used in G.O. Sars' latin diagnosis of the variety. According to the diagnosis in G.O. Sars, the variety is larger (reaching $4.6 \mathrm{~mm}$ in length), with deeper suture and much finer spirals distributed over most of the shell (not just the basal part). The syntype illustrated in Figure 76 and 77, is broadly conical, not rather cylindrical as the specimen of $O$. divisa from northern Norway shown in Figure 73. The spiral incisions on the lower half of the shell are also less concspicuous than in the specimen in Figure 73. Altogether the morphological peculiarities are too few to proclaim this a separate species, although future studies of living specimens might certainly justify a reevaluation of its specific status.

\section{Ondina warreni (Thompson, 1845)}

Figure 78-79

\section{Rissoa Warreni Thompson, 1845:315}

Odostomia Warrenii (Thompson) - Forbes \& Hanley 1850-51; Jeffreys 1869, 1870

Odostomia warreni (Thompson) - Marshall 1900

Odostomia warreni var. intermedia Marshall - Marshall 1893

Odostomia warreni var. zetlandica Marshall - Marshall 1900

Chemnitzia Warrenii (Thompson) - Clark 1855

Ptychostomon (Ondina) warreni (Thompson) - Kobelt 1903

Menestho (Evalea) warreni (Thompson) - Winckworth 1932; Høisæter 1986

Evalea warreni (Thompson) - Fretter et al. 1986; Graham 1988 Ondina warreni (Thompson) - van Aartsen 1987; Smith \& Heppell 1991; Warén 1991; Peñas et al. 1996

Ondina cf. warreni (Thompson) - Høisæter 2009 Odostomia obliqua var. Warrenii (Thompson) - Jeffreys 1867 Turbonilla obliqua (Alder) - Lovén 1846a, b (not Odostomia obliqua Alder, 1844; fide Forbes \& Hanley 1850-51)

Type material: Not known.

Type locality: Portmarnock, Dublin Bay, Ireland.

Material seen: Norway - Skagerrak, 11 spms; Shetland - 3 shs (ZMBN 28632 Shetland, Friele don., Jeffreys det. 'Ondina warreni Thoms. type')

Diagnosis: Shell: One of three Norwegian Ondina species with distinct spiral grooves, predominantly on the basal part of the shell. According to Fretter et al. (1986) the first postlarval whorl is covered with coarse spiral incisions. Best distinguished from $O$. divisa by the more convex whorls, deeper suture and a proportionally wider first postlarval whorl (compare Figures 72 and 78). Further, wider and with more whorls at same length, very fine overall spiral striation in addition to coarse spirals at lower part of body whorl, and somewhat wider umbilicus. Soft parts: Not known. Operculum: Not known.

Biology: Not known.

Distribution: This species has been reported twice from Norwegian waters, from Oslofjorden 75-110 m (Jeffreys 1870) (a record apparently repeated in the Synoptic Tables in G.O. Sars 1878) and from Raunefjorden, $180 \mathrm{~m}$ (Friele 1874:22). The last record was also repeated in the Synoptic Tables in G.O. Sars (1878), but retracted by Friele himself (in Norman 1879:60). Warén (1991) mentions the report in G.O. Sars (whose 
determination he questions), but fails to refer to Jeffreys (1870). My material supports the record of Jeffreys, but indicates that the distribution in Norway is restricted to the Skagerrak region, including Oslofjorden. Outside Norway distributed from off the north of Scotland south to Biscay according to Fretter et al. (1986). Mainly distributed along the western Irish and British coasts between 30 and $60 \mathrm{~m}$ on gravelly and sandy mud (Graham 1988). Reported as the most common species of Ondina on the Atlantic coasts of southern Europe and also common in the Mediterranean (Peñas et al. 1996, van Aartsen et al. 1998, Cachia et al. 2001, Öztürk et al. 2013).

Remarks: Available literature indicates that (at least) two different forms are known under this name. The form from Shetland (var. zetlandica Marshall, the one at left in Figure 79) is rather different from the nominal type from further south on British and Irish coasts. This form is described as: "...an exact miniature of Limnaea stagnalis, and the dimensions are the same as those of O. obliqua, ..." (Marshall 1900:288). The 11 specimens (referred to as $O$. warreni above) in my material from Skagerrak resemble Warén's SEM-photo of $O$. warreni but has a higher and more dominating body whorl and aperture than that specimen.The largest shell of three also from Shetland (ZMBN 28632) is much closer in proportions to my specimens. That the species is variable is evident from the illustrations in Peñas et al. 1996 and Öztürk et al. 2013).

\section{Ondina diaphana (Jeffreys, 1848)} Figure 80

\section{Odostomia diaphana Jeffreys, 1848:341}

Menestho (Evalea) diaphana (Jeffreys) - Winckworth 1932; Høisæter 1986

Evalea diaphana (Jeffreys) - Fretter et al. 1986; Graham 1988 Ondina diaphana (Jeffreys) - van Aartsen 1987; Smith \& Heppell 1991; Warén 1991; Schander 1995; Schander et al. 2003; Høisæter 2009

Odostomia diaphana Jeffreys - Jeffreys 1867; Friele 1874; Jeffreys 1884; Marshall 1900; Warén 1980

Odostomia diaphana var. inflata Marshall - Marshall 1893 Ptychostomon (Ondina) diaphanum Jeffreys - Kobelt 1903 Odostomia obliqua Alder (in part) - Forbes \& Hanley 1850-51 Chemnitzia obliqua Alder (in part) - Clark 1855

Type material: Holotype, one shell $(2.6 \mathrm{~mm})$, USNM 753707.

Type locality: Exmouth, south western Great Britain.

Material seen: Norway - Hordaland, 1 spm; Møre og Romsdal 1 spm, 3 shs; Nordland, 1 spm.

Diagnosis: Shell: Small and slender. Shell surface smooth and shiny. See further discussion under $O$. perezi below. Soft parts: Mentum deeply cleft, almost to the level of the eyes. Tentacles rather long and recurve laterally at their tips. Eyes very close together. Foot rather broad and bifid posteriorly (from Fretter et al. 1986:583. Also good photograph, their Figure 398). Operculum: Not studied.

Biology: Not known, but see $O$. perezi below.

Distribution: Reported from Norway by Friele (1874) from $110-130 \mathrm{~m}$ in Bergen (c. $60^{\circ} 25^{\prime} \mathrm{N}$ ), a single specimen together with one Liostomia clavula and several Ondina divisa. This record was accepted by G.O. Sars (1878), and Norman (1879), but is not mentioned by Warén (1991). In the Zoological Museum in Bergen, a shell from Florø $\left(61^{\circ} 36^{\prime} \mathrm{N}\right)$ is stated to be identified by Jeffreys. In my material only a few undisputable specimens and shells from two stations, from Møre og Romsdal county, in the outer archipelago in the southern part of the county (between $62^{\circ} 15^{\prime}$ and $62^{\circ} 20^{\prime} \mathrm{N}$ ), in two dredge hauls from between 25 and $50 \mathrm{~m}$, sand, gravel and stones, and large shell fragments. Further a shell from Hjertøysund, near Bodø (approx. $67^{\circ} 18^{\prime} \mathrm{N}, 14^{\circ} 21^{\prime} \mathrm{E}, 40-30 \mathrm{~m}$ ). My material demonstrates that it is living at least as far north as $67^{\circ} 20^{\prime} \mathrm{N}$. Outside Norway it is recorded from western Sweden (very rare, Schander 1995), the Faroes (Schander 1995), northern Iceland and southwards along the western British coast (Warén 1991). According to Fretter et al. (1986) this is a southern species ranging from the Mediterranean north to the British Isles. According to van Aartsen (1987) represented in the western Mediterranean by a subspecies, $O$. diaphana dilucida (Monterosato, 1884). Peñas et al. (1996) mention Ondina dilucida from the western Mediterranean, but do not record $O$. diaphana as well. Öztürk et al. (2013) do not mention O. dilucida, but report five specimens of $O$. diaphana from the Turkish coasts.

Remarks: The main difference from the far more common $O$. divisa, is the complete lack of spirals and a comparatively larger body whorl. A photograph of a living specimen in Fretter et al. (1986), shows striking similarities to O. divisa (see Figure 74). Van Aartsen (1997) and Warén (1991) disagree concerning the possible synonymy of $O$. perezi with $O$. diaphana. While Warén, in line with Hylleberg Kristensen (1970), Rodriguez Babio \& Thiriot-Quiévreux (1975) and several other authors, claim that the two are synonymous, van Aartsen, followed by Schander (1995), keeps them apart although based on rather indirect evidence. If the two are distinct $O$. diaphana should be smaller (according to van Aartsen (1987) around $1.6 \mathrm{~mm}$ long), more slender and more shiny. The specimen from Møre og Romsdal pictured in Figure 80 above is c. $2.5 \mathrm{~mm}$ long, and thus appreciably longer than the length given by van Aartsen for $O$. diaphana s.s. See further discussion under $O$. perezi below.

\section{Ondina perezi (Dautzenberg \& Fischer, 1925)} Figure 81

Odontostomia (Auristomia) Perezi Dautzenberg \& Fischer, 1925:81

Ondina perezi (Dautzenberg \& Fischer) - van Aartsen 1987; Smith \& Heppell 1991; Schander 1995; Schander et al. 2003; Høisæter 2009 
Odostomia (Brachystomia) perezi (Dautzenberg \& Fischer) Winckworth 1932

Odostomia diaphana (Jeffreys) - Warén 1980

Menestho (Evalea) diaphana (Jeffreys) - Hylleberg Kristensen 1970; Høisæter 1986

Evalea diaphana (Jeffreys) - Fretter et al. 1986; Graham 1988

Ondina diaphana (Jeffreys) - Warén 1991

Type material: Syntypes USNM 471508 and in coll. Dautzenberg, Inst. Royal de Sciences Naturelles, Bruxelles.

Type locality: Bisayeres and Goulet de Brest in western France, found in shells inhabited by Phascolion strombus.

Material seen: None.

Diagnosis: Shell: Much like $O$. diaphana but with a dull shell surface, larger, to $2.5 \mathrm{~mm}$ (van Aartsen 1987) or 2.9 mm (Warén 1991) and flatter, less convex whorls. (From van Aartsen 1987 and Schander 1995). Soft parts: Not known. Operculum: Not known.

Biology: By most authors (e.g. Hylleberg Kristensen 1970) considered to be host specific on Phascolion strombus. This is followed up by both Warén (1991) and Schander (1995).

Distribution: Not yet reported from Norway, but as this species is far more common than $O$. diaphana in western Sweden, it should certainly occur together with Phascolion strombus in the Norwegian part of Skagerrak. The distribution outside Norway is impossible to specify because of the confusion with $O$. diaphana. It is confirmed from the Faroes, the Swedish west coast, the Atlantic coast of France and the British Isles (Schander 1995).

Remarks: As discussed under Ondina diaphana, authorities disagree as to whether $O$. perezi is a good species or only a synonym of $O$. diaphana (Ankel 1959, Hylleberg Kristensen 1970, Gibbs 1978, Warén 1980, 1991 and Fretter et al. 1986, argues for synonymy. Van Aartsen 1987, Schander 1995 and Schander et al. 2003 prefer to classify it is a separate species.) As I have not seen any specimens that unambiguously could be referred to $O$. perezi, the following discussion is based solely on literature data.

Van Aartsen et al. (1984) note that the European Ondina species may be divided into two distinct groups, those without spiral sculpture and those with such sculpture. The subdivision of the former of these groups is exceedingly difficult, as is illustrated by the $O$. diaphana/O. perezi dispute. The third north European member of this group, O. normani, was not mentioned at all by van Aartsen (1987), and was not compared directly with $O$. diaphana $(=O$. perezi) by Warén. In my opinion $O$. normani is a fairly common member of the Norwegian pyramidellid fauna (see below). This opinion is based on my interpretation of O. diaphana, as illustrated in Figure 80, an opinion shared by Schander (1995: Figure 1 E). The SEM photo in Warén (1991: Figure 34B), said to be of $O$. diaphana is most likely of $O$. perezi, as both the locality and size indicate (Roscoff, France and $2.9 \mathrm{~mm}$ ). If my interpretation is correct, the size difference between the two presumed species is not as large as claimed by van Aartsen (1987) (2.5 against $1.6 \mathrm{~mm}$ ). Drawings of the two in Fretter et al. (1986) are of shells respectively 3.0 and $2.4 \mathrm{~mm}$ long, and my specimen shown above (Figure 80 ) is of a $2.6 \mathrm{~mm}$ long specimen.

Schander et al. (2003) included specimens of both $O$. diaphana and $O$. perezi as well as $O$. divisa in their molecular study of various pyramidellids. Their comparison of the mitochondrial $16 \mathrm{~S}$ gene showed that $O$. diaphana and $O$. perezi differed in only a single character. This was based, however, on a very reduced dataset only those 200 characters that could be unambiguously aligned for the total set of 32 species. When only the three Ondina species were included, all 483 characters could be unambiguously aligned, and then $O$. diaphana and $O$. perezi differed in a total of 16 characters. This as opposed to a similar comparison between Pyrgiscus rufus and P. fulvocinctus which differed in seven characters.

If a specimen of an Ondina species is found within the aperture of a shell inhabited by Phascolion strombus, this has been taken as a strong indication that the species in question is actually $O$. perezi. In my material a single specimen from Grimseidpollen (c. $60^{\circ} 16^{\prime} \mathrm{N}, 13-15 \mathrm{~m}$, coll. and leg. S. Bakke 1964) was found within the aperture of a Littorina shell inhabited by Phascolion strombus. Unfortunately, today it is partly broken and rather corroded by acidic conditions, and not any longer easily identifiable. A camera lucida drawing of the undamaged shell presented in Figure 82, is more like $O$. normani than $O$. perezi. I therefore suspect that more than one species of Ondina might live together with Phascolion strombus.

\section{Ondina normani (Friele, 1886) Figure 82}

Odostomia Normani Friele, 1886:29

Odostomia normani Friele - Friele \& Grieg 1901; Odhner 1939

Ptychostomon normani (Friele) - Kobelt 1903

Toledonia normani (Friele) - Thiele 1928

Menestho (Evalea) normani - Høisæter 1986

Ondina normani (Friele) - Smith \& Heppell 1991; Warén 1991;

Schander 1995; Høisæter 2009

Type material: Two syntypes ZMBN 21621.

Type locality: Florø $\left(61^{\circ} 36^{\prime} \mathrm{N}\right), 54 \mathrm{~m}$.

Material seen: Norway - Skagerrak, 4 spms; Møre og Romsdal 11 spms; Nord-Trøndelag, 2 spms; Nordland, 3 spms.

Diagnosis: Shell: Smooth and glistening, unsculptured. Small first postlarval whorl. Fairly conical shell (as opposed to the rather more cylindrical species of Liostomia). Columellar tooth retracted and weak. A distinct umbilicus is usually present. Soft parts: Not known. Operculum: Not known.

Biology: Not known, but the single specimen from Grimseidpollen pictured in Figure 82 indicates that it might be commensal with Phascolion strombus. 
Distribution: So far only reported from Norway. In addition to the type material from Florø (Warén 1991), recorded from Bergen and outer Sognefjorden (Friele \& Grieg 1901), and two specimens and five shells from Tromsø $\left(69^{\circ} 40^{\prime} \mathrm{N}\right)$ (Schander 1995). In my material 16 specimens and five shells from all around the coast from Saltfjorden $\left(67^{\circ} 10^{\circ} \mathrm{N}, 170-90 \mathrm{~m}\right.$, shell gravel) to the Skagerrak coast. Thus the species seems to be fairly common in Norwegian waters.

Remarks: The species is discussed in Warén (1991) and Schander (1995). Based on studies of the type material, Høisæter (1986) accepted it as a valid member of Ondina. For some reason Schander (1995) claimed that Høisæter (1986) synonymized $O$. normani with $O$. diaphana, which is not true. But some specimens from western Norway tend towards $O$. diaphana, as shown in Figure 82.

\section{Ondina obliqua (Alder, 1844)}

Figure 83

Odostomia obliqua Alder, 1844:327

Odostomia obliqua Alder - Alder 1848; Forbes \& Hanley 185051; Jeffreys 1867; Marshall 1893, 1900

Chemnitzia obliqua (Alder) - Clark 1855

Ptychostomon obliquum (Alder) - Kobelt 1903

Odontostomia (Ondina) obliqua (Alder) - Dautzenberg \& Fischer 1925

Menestho (Evalea) obliqua (Alder) - Winckworth 1932; Høisæter 1986

Ondina obliqua (Alder) - van Aartsen 1987; Smith \& Heppell

1991; Warén 1991; Peñas et al. 1996; Høisæter 2009

Type material: Not known.

Type locality: Tynemouth, outside Newcastle, North Sea coast of England (fide Jeffreys 1867).

Material seen: Norway - Hordaland, 2 shs.

Diagnosis: Shell: Distinguished by its upturned and almost disjoint protoconch and the rapidly increasing whorls. Soft parts: Not known. Operculum: Not known.

Biology: Not known.

Distribution: Not previously recorded from Norway. In my material a large specimen from Fitjar $\left(59^{\circ} 54^{\prime} \mathrm{N}, 18\right.$ $\mathrm{m}$, leg. Per Johannessen) and a single old and worn shell from Raunefjorden (Hillersholmen, c. $60^{\circ} 18^{\prime} \mathrm{N}, 8 \mathrm{~m}$, coarse shell gravel), possibly subfossil. Outside Norway known from the Swedish west coast (Koster area, Warén 1991) and the British Isles south to the Biscay (Fretter et al. 1986) and the Mediterranean, quite rare (Warén 1991). Mentioned from the Scottish North Sea coast, (McKay \& Smith 1979). Sparingly in the western Mediterranean (Peñas et al. 1996).

Remarks: A reference to G.O. Sars (1878) in Høisæter (2009) is due to a misunderstanding. The shell at left in Figure 83 has lost the upturned protoconch. It has a golden brown surface which might be due to a periostracum. It is reported as being quite rare throughout its distribution, and is obviously extremely rare in Norwegian waters.

\section{Liostomia G.O. Sars, 1878}

Type species, by subsequent designation: Turbonilla clavula Lovén, 1846; designated by Monterosato 1884:95. Western Sweden (Bohuslän).

Pyramidellids with cylindrical to slightly conical shells, with short to moderately long whorls. Outer lip of aperture almost straight, parallell to the main axis. No spiral sculpture. No columellar fold. Umbilicus present, may be deep and spacious. Protoconch intorted, completely immersed in the first teleoconch whorl. Second teleoconch whorl usually $<350 \mu \mathrm{m}$ high. Operculum light horncoloured, thin and translucent with a small, excentric spire, and no 'anchor' or internal process (see G.O. Sars, 1878, Figure 39).

This is seen as a polyphyletic group which was already pointed out by G.O. Sars. He erected the genus for two species which he found to be very similar to Odostomia, but which did not have a columellar fold and possessed a thin earshaped operculum. Except for these characteristics, the two species had very little in common. Monterosato (1884) designated Turbonilla clavula Lovén, 1846 as genotype, while Dall \& Bartsch (1904) happened to choose Rissoa eburnea Stimpson, 1851. The taxonomic status has been disputed by later workers. Van Aartsen (1987) regards it as part of Odostomia s.s., while Fretter et al. (1986) treat it as a separate genus. Formally (e.g. Thiele 1929) it was seen as a subgenus of Menestho Møller, 1842. Warén (1991) reviewed the group and expanded it to include four species.

Key to the species of Liostomia, based on shell morphology

1a. Shell conical and turriculate with tumid whorls ..Liostomia eburnea

1b. Shell more or less cylindrical with flattened whorls ......2

2a. Shell narrow cylindrical, with smooth, shiny, unblemished surface Liostomia clavula

2b. Shell slightly conical, often with corrosion marks ..........3

3a. Shell around 1.6-1.7 $\mathrm{mm}$ long with four whorls ..Liostomia afzelii

3b. Shell larger, around $2.25 \mathrm{~mm}$ long with four whorls, deep and channeled suture Liostomia hansgei 


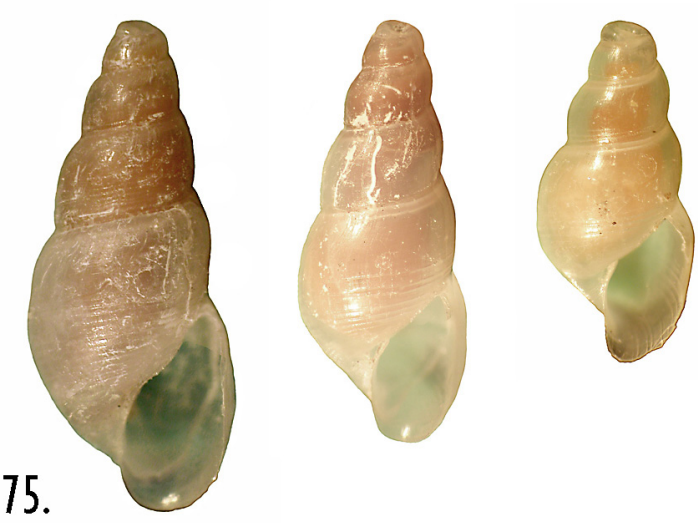

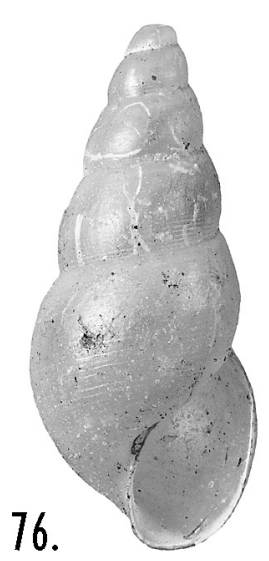
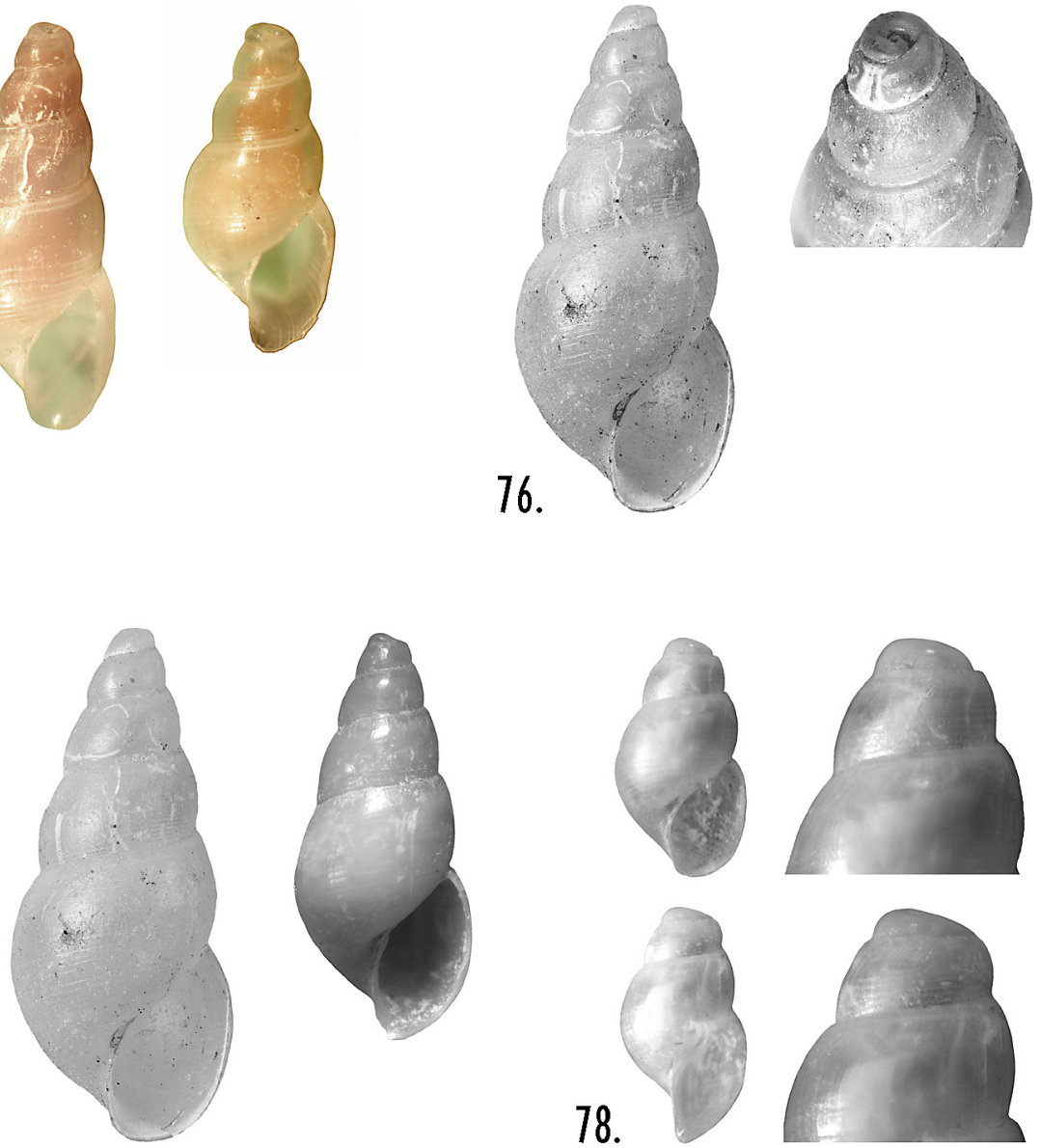

78.
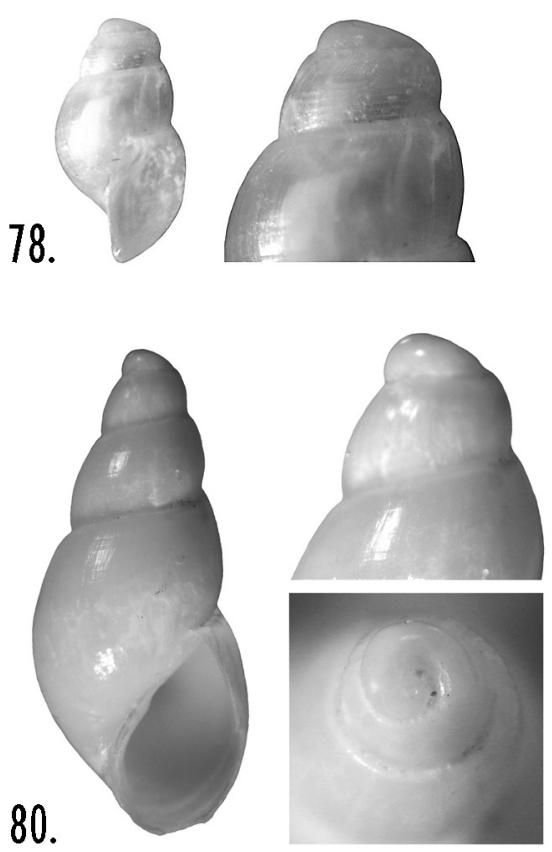
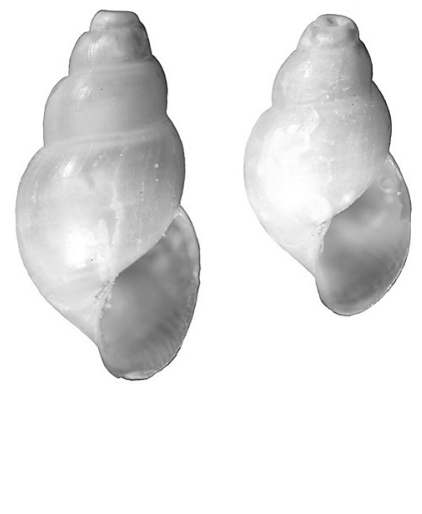

79.
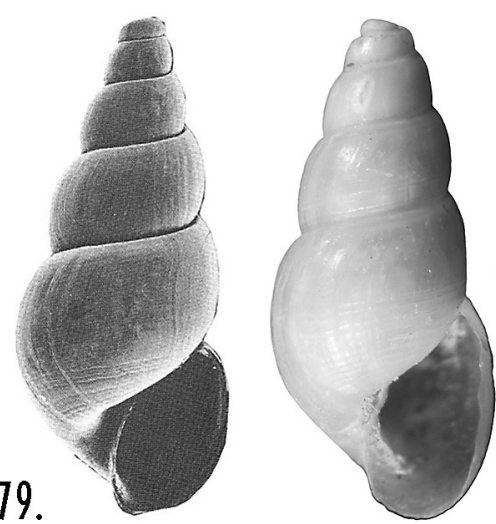

Figure 75. Ondina divisa cf. rubra, three specimens from Oseberg oilfield, 60³4.7’'N, 0248.7’'E, $106 \mathrm{~m}, 3.6,3.1$ and $2.5 \mathrm{~mm}$ (ZMBN 83217). Figure 76. Ondina divisa nobilis. Syntype NHMO D 1116, $4.2 \mathrm{~mm}$.

Figure 17. Ondina divisa nobilis. From left: a specimen from Marvollvika, Bodø, (Nordland), 67²' $\mathrm{N}, 1^{\circ} 35^{\prime} \mathrm{E}, 25 \mathrm{~m}, 4.05 \mathrm{~mm}$ (N 21-80); syntype NHMO D 1116, $4.2 \mathrm{~mm}$; a specimen from Nordfjorden in Rødøy, (Nordland), 66 $34.3^{\prime} \mathrm{N} 13^{\circ} 30.5^{\prime} \mathrm{E}, 15-11 \mathrm{~m}, 3.35 \mathrm{~mm}(\mathrm{~N}$ 15-84).

Figure 78. Ondina warreni, a specimen from near Grimstad (Aust Agder), $58^{\circ} 19^{`} \mathrm{~N}, 1.55 \mathrm{~mm}$.

Figure 79. Ondina warreni. The one at left from Shetland (from Warén 1991), $3.3 \mathrm{~mm}$. The other three from Grønsfjorden, Lindesnes, (Vest

Agder), $58^{\circ} 02^{\prime} \mathrm{N}, 07^{\circ} 03^{\prime} \mathrm{E}, 165 \mathrm{~m}, 3.5,2.6,2.15 \mathrm{~mm}$ (S 89-88).

Figure 80. Ondina diaphana, from Gurskøy in Herøy (Møre og Romsdal) 62 $18^{\prime} \mathrm{N}, 05^{\circ} 38^{\prime} \mathrm{E}, 35-30 \mathrm{~m}, 2.55 \mathrm{~mm}$ (ZMBN 83241). 

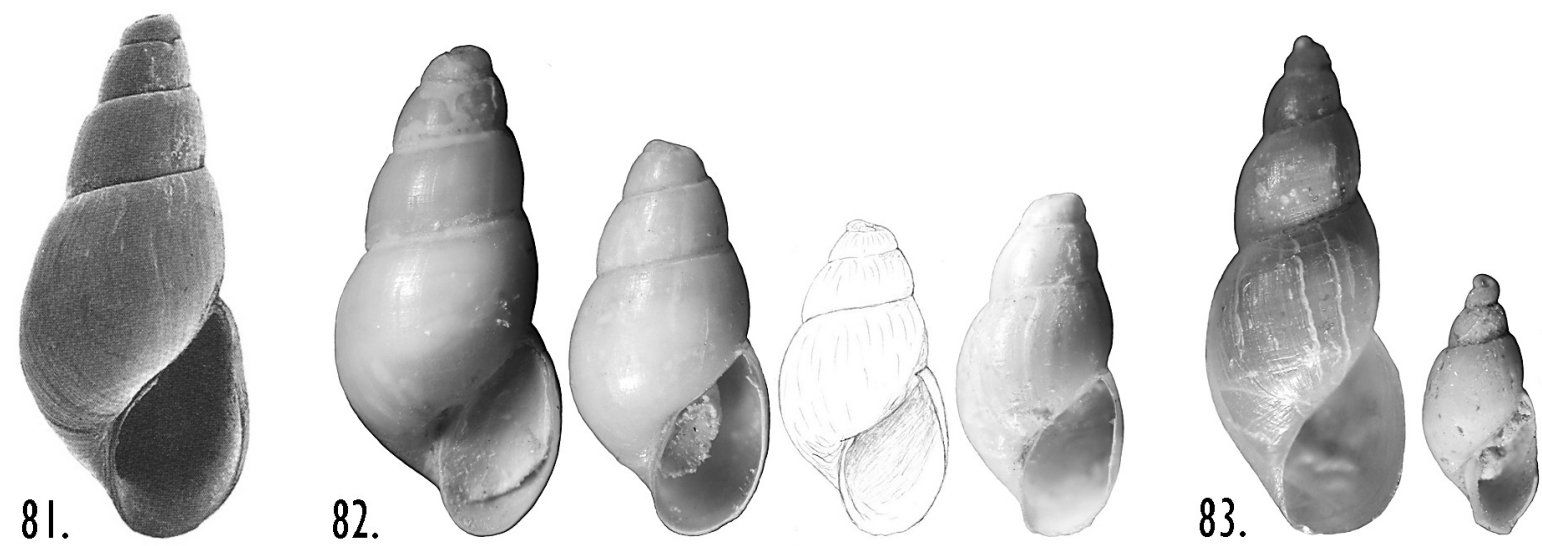

Figure 81. Ondina perezi. Specimen from Roscoff, France. Copied from Warén 1991 (as O. diaphana)

Figure 82. Ondina normani. From left: a specimen from Ytre Maløya, Grimstad, 58¹9.1’N, 08³6.2’E, 50-40 m, 2.7 mm (G 29-70), one from Gjerdeviken, Aure (Møre og Romsdal), 63¹7.4’N, 08²3.2’E, 2.2 mm (ZMBN 83239), one from Grimseidpollen, W of Pålsholmen, $60^{\circ} 16^{\prime} \mathrm{N}, 05^{\circ} 16^{\prime} \mathrm{E}, 20-23 \mathrm{~m}$, found within the aperture of a Littorina shell inhabited by Phascolion strombus (ZMBN 83243), and finally a specimen from Talgsjøen NE of Kristiansund, $63^{\circ} 10^{\prime} \mathrm{N}, 07^{\circ} 51^{\prime} \mathrm{E}, 20-80 \mathrm{~m}, 1.9 \mathrm{~mm}$ (ZMBN 83238). The latter is intermediate in shape between $O$. normani and $O$. diaphana.

Figure 83. Ondina obliqua. A specimen from Fitjar, 59 $54^{\prime} \mathrm{N}, 05^{\circ} 10.3^{\prime} \mathrm{E}, 18 \mathrm{~m}, 4.9 \mathrm{~mm}$ (Fi 5 21.06.00), and a shell from Raunefjorden, Hillersholmen, $60^{\circ} 17.8^{\prime} \mathrm{N}, 05^{\circ} 11.1^{\prime} \mathrm{E}, 8 \mathrm{~m}, 2.65 \mathrm{~mm}$ (ZMBN 83245).

\section{Liostomia afzelii Warén, 1991}

Figures 84, 89

Liostomia afzelii sp.n. - Warén, 1991:106

Liostomia afzelii Warén - Cachia et al. 2001; Schander et al. 2003; Høisæter 2009

Odostomia afzelii (Warén) - Peñas et al. 1996

Liostomia clavula (Lovén) - G.O. Sars 1878 (according to Warén 1991)

Odostomia (Liostomia) clavula - van Aartsen (1987) [in part]

Type material: Holotype and numerous syntypes SMNH 4096 and 4097.

Type locality: Swedish west coast, Koster area, south of Lilleskär, 30-40 m.

Material seen: Norway - Skagerrak, 7 spms; Møre og Romsdal 2 spms - Shetland 1 sh (ZMBN 28 638, Friele don., Jeffreys det. Ptychostomon clavulum Lov.).

Biology: Not known.

Diagnosis: Shell: Soft parts: Not known. Operculum: Not known.

Distribution: A single specimen from Korsfjorden 150-300 $\mathrm{m}$, mentioned as additional material in the original description, is the only previous Norwegian record. According to Warén (1991) the record of L. clavula in G.O. Sars (1878) from Lofoten $\left(\right.$ c. $\left.68^{\circ} \mathrm{N}\right)$ should definitely be referred to $L$. afzelii. In my material two specimens and three shells from Møre og Romsdal. The two specimens are from a species rich sample from Breisunddjupet $\left(62^{\circ} 29^{\prime} \mathrm{N}, 120-60 \mathrm{~m}\right.$, shell sand). Seven specimens in the material from Skagerrak also most likely belong to L. afzelii. Apparently more common in the Skagerrak area than further north. Outside Norway it is known from western Sweden, Shetland and off Tunis in Tunisia (Warén 1991). Reported from the western Mediterranean by Peñas et al. (1996). Also reported from the Turkish coast (Öztürk et al. 2013).

Remarks: Separated from L. clavula by Warén (1991). Not recognized as a separate species by van Aartsen. See further Figure 89, and Remarks under L. clavula below.

\section{Liostomia clavula (Lovén, 1846)} Figures 85, 89

Turbonilla clavula Lovén, 1846a:49

Eulimella clavula (Lovén) - Forbes \& Hanley 1850-51; Jeffreys 1859

Chemnitzia clavula (Lovén) - Clark 1855

Odostomia clavula (Lovén) - Jeffreys 1867, 1870; M. Sars 1870; Friele 1874; Jeffreys 1884; Marshall 1899

Odostomia clavulus (Lovén) - Peñas et al. 1996;

Odostomia (Liostomia) clavula (Lovén) - Monterosato 1884; van Aartsen 1987

Menestho (Liostomia) clavula (Lovén) - Winckworth 1932; Høisæter 1986

Liostomia clavula (Lovén) - G.O. Sars 1878; Petersen 1888; Fretter et al. 1986; Graham 1988; Smith \& Heppell 1991; Warén 1991; Schander et al. 2003; Høisæter 2009

Liostomia clavulus (Lovén) - Cachia et al. 2001

Ptychostomon (Liostomia) clavula (Lovén) - Kobelt 1903:109

Odostomia pistillus sp.n. - Brugnone 1873:9. 
Type material: Four syntypes SMNH 1519.

Type locality: Gullmarsfjorden, Swedish west coast.

Material seen: Norway - Skagerrak, 1 spm; Sogn og Fjordane, 1 sh (ZMBN 16634, Florø, 61ํ36’ N, 60 m, Friele col. $\&$ det.); Møre og Romsdal 10 spms, 20 shs.

Diagnosis: Shell: Smooth and glossy, small, narrow, cylindrical. Whorls fairly convex, body whorl evenly rounded. No columellar tooth. Soft parts: Cachia et al. (2001:106) describe the soft parts of a specimen from Malta: "The specimen is colourless with flat, laterally grooved triangular tentacles. Mentum short. Eyes large, very closely set and at centre of head. Foot elongated, bilobed anteriorly and rounded posteriorly. Digestive gland brown with scattered black spots." Soft part also described by Lovén (1846b) and Clark (1855). Operculum: Thin, corneous, white.

Biology: According to Fretter et al. (1986:590): "This species is most reliably found in association with Pennatula and therefore on the soft bottoms on which it occurs, $30-90 \mathrm{~m}$ deep (Maas 1965)." I could not, however, find any support for this association in Maas (1965). The live caught specimens in my material, all from fjords in Møre og Romsdal county, were found between 62 and $42 \mathrm{~m}$, on sandy bottom.

Distribution: Three previous records from Norway. G.O. Sars (1878) reported a single shell from Lofoten (since referred to $L$. afzelii, see above), but found also a number of specimens near Tananger outside Stavanger $\left(58^{\circ} 56^{\prime} \mathrm{N}\right)$ and a single shell in Oslofjorden. Friele (1874) reported a single specimen from Bergen (see Ondina diaphana above). As these early authors did not distinguish between $L$. afzelii and $L$. clavula some or all of these records might refer to L. afzelii. Warén (1991) confirmed its presence in Norway as he found two specimens in Korsfjorden, 150-300 m. In my material a single specimen (and three shells) from Skagerrak, ten specimens and 16 shells in several samples from Møre og Romsdal, the northernmost from Frænafjorden $\left(62^{\circ} 50^{\prime} \mathrm{N}, 62-50 \mathrm{~m}\right.$, sand) containing six specimens and nine shells. Outside Norway the species has been reported from the Swedish west coast, the British Isles, northern Spain and the Mediterranean (Warén 1991). Peñas et al. (1996) confirm the presence in the western Mediterranean. Also reported from the Turkish coast (Öztürk et al. 2013).

Remarks: The opinion of van Aartsen (1987) that Odostomia pistillus Brugnone, 1873 (mainly occurring in the Mediterranean) was a narrower and smaller form of the wider and slightly more conical L. clavula was based on a misinterpretation of Lovén's $L$. clavula. The examination by Warén (1991) of Lovén's types showed that $L$. clavula was based on the slender form. Warén further concludes that the two forms are sufficiently distinct to justify the erection of a separate species, L. afzelii for the wide form. Van Aartsen maintained that the two are extremes of a single species (Warén 1991), but the molecular analysis of Schander et al (2003), indicates that the two are separate species. A specimen of each are shown side by side in Figure 89. Peñas et al. (1996) and Cachia et al. (2001), use the spelling 'clavulus' rather than 'clavula'. This may be because the specific name is grammatically a noun and thus the ending need not agree in gender with the generic name (ICZN Article 34.2.1). Here 'clavula' is used following most other recent authors.

\section{Liostomia eburnea (Stimpson, 1851) \\ Figure 86}

\section{Rissoa eburnea Stimpson, 1851:14}

Rissoella? eburnea (Stimpson) - Gould \& Binney 1870; G.O. Sars 1878 (in synonymy)

Liostomia eburnea (Stimpson) - G.O. Sars 1878; Whiteaves 1901; Norman 1902; Odhner 1915; Thiele 1928; Nordsieck 1972; Warén 1991; Høisæter 2009

Odostomia (Liostomia) eburnea (Stimpson) - Bartsch 1909; Bush 1909; van Aartsen 1987

Ptychostomon (Liostomia) eburnea (Stimpson) - Kobelt 1903 Menestho (Liostomia) eburnea (Stimpson) - Høisæter 1986 (not Jeffreysia nitida sp.n. - Friele 1876:61; Warén 1991 Menestho (Liostomia) nitida (Friele, 1876 ex M. Sars MS) Høisæter 1986)

Type material: Neotype (4.2 mm), USNM 503943 (Figure 27C in Warén 1991).

Type locality: Massachusetts Bay, off Cape Ann $\left(42^{\circ} 38^{\prime} \mathrm{N}\right.$, $54 \mathrm{~m}$ ) USA. (This is the locality of Stimpson's specimen, now lost. The neotype is from Maine, Frenchmans Bay, $27 \mathrm{~m}$ ).

Material seen: Norway - Finnmark, 1 sh (ZMBN 28182, Vadsø).

Diagnosis: Shell: Large for the 'genus', up to $4.6 \mathrm{~mm}$, solid, body whorl swollen and large compared to penultimate whorl. Soft parts: Not known. Operculum: See G.O. Sars 1878, Figure 10, 13c).

Biology: Not known.

Distribution: In Norway confirmed only from Varangerfjorden in east Finnmark (G.O. Sars 1878, Norman 1902, both based on the same material). According to Warén (1991) a number of shells in SMNH and BMNH from 'northern Norway'. These are probably also from the same lot in Varangerfjorden. A single known shell of Jeffreysia nitida was taken by M. Sars near Florø $\left(61^{\circ} 36^{\prime} N\right)$. Outside Norway it is known from Massachusetts to Gulf of St. Lawrence, east to Spitzbergen (Odhner 1915, Warén 1991) and the Russian part of Barents Sea and Chuckchi Sea (Kantor \& Sysoev 2006).

Remarks: Although recorded only a few times, at least nine illustrations of this species have been published, i.e. in Stimpson (1851), Gould \& Binney (1870), G.O. Sars (1878), Bush (1909), Odhner (1915), van Aartsen (1987), Warén (1991) (two shells) and finally Kantor \& Sysoev (2006). The species figured by Gould \& Binney is not the same species as the one described by Stimpson (as also remarked by Bush 1909). The gap between the Norwegian location and the American type locality is large, and may rise the question if specimens from both locations 
really belong to the same species, but a comparison of the shells indicate a close relationship.

Warén (1991) synonymized Jeffreysia nitida Friele with L. eburnean, although he did not succeed in locating the only known shell of $J$. nitida, and his decision is thus based on Friele's (sketchy) drawing and description. Friele compared the actual specimen with Stimpson's drawing of L. eburnea, and found them easy to separate. Also G.O. Sars (1878) had access to both specimens and concludes that they were specifically different (according to Warén, Sars found them to be identical). I find it unlikely that the two are the same species, both because the oceanographic conditions near Florø are definitely not Arctic in any sense (like they are in all other north-east Atlantic locations where L. eburnea has been recorded), and I have a high regard for the opinion of both Friele and G.O. Sars. The lack of material precludes any further discussion, and J. nitida must remain an enigma. I agree with Warén that the generic placement of $L$. eburnea is just a matter of convenience, no other described genus seems to fit.

\section{Liostomia hansgei Warén, 1991 Figures 87-89}

Liostomia hansgei sp.n. - Warén 1991:108

Liostomia hansgei Warén - Peñas et al. 1996; Høisæter 2009

Type material: Holotype and four paratypes, SMNH 4098 and 4099.

Type locality: Swedish west coast, Koster area, south of Lilleskär, 30-40 m, fine silt.

Material seen: Norway - Hordaland, 6 spms; Nordland, $1 \mathrm{spm}$.

Diagnosis: Shell: Medium size, fairly solid, with deep suture. Cylindrical, colour-less, often covered by solid ferruginuous deposit, has a blunt apex and a small aperture. Soft parts: (Based on a specimen from Fanafjorden, mid-part, $145-155 \mathrm{~m}$ ). The front of the foot strongly ciliated. On the edges of the foot and in a wide band behind the eyes, a mixture of scattered, dirty white, opaque, and somewhat bigger oily-clear, and deep purple-brown spots and blotches. A collection of larger purple-brown pigment in the heart region. Pigmentation dense and gradually more pronounced farther up on the specimen. Opaque white pigment visible beneath operculum on the side of the columella. Small, inconspicuous eyes. Short wide, triangular tentacles. (Figure 88). Pigmented mantle organ conspicuous, yellow, sometimes with brownish edges. Long, narrow, colourless, slightly opaque, ciliated ridge in the roof of the mantle. Spots of deep purple on the part of the body where the pigmented organ is found. Operculum: Very thin and translucent, lacking 'ridge' on its inner side.

Biology: Not known.

Distribution: Earlier records from Norway: three specimens and two shells from Korsfjorden and the outer part of Fanafjorden (60²'-14'N, 150-280 m) (Warén 1991). In my material seven specimens of which six are from the Espegrend area, mostly from the outer part of Fanafjorden, 140-220 m (close to the localities in Warén 1991). Apparently the commonest species of Liostomia in the area around Bergen. In addition to the material from Fanafjorden/Korsfjorden, two shells from around $63^{\circ} 10^{\prime} \mathrm{N}-63^{\circ} 15^{\prime} \mathrm{N}(110-145 \mathrm{~m}$, soft to sandy bottom). Finally a single specimen from Tomfjorden $\left(66^{\circ} 15^{\prime} \mathrm{N}\right.$, 380-300 m) and two shells from locations in the same general area but from somewhat shallower depths (80-160 m, mostly rather soft bottom). Outside Norway reported from western Sweden, and from the stomachs of a number of Astropecten taken near Barcelona in the western Mediterranean (Peñas et al. 1996).

Remarks: Figure 89 shows specimens with same number of whorls of the three species of Liostomia from the southern part of Norway. L. hansgei is much longer and wider at same number of whorls than both L. afzelii and L. clavula. While the narrow, almost cylindrical $L$. clavula have a polished, unblemished shell surface, most specimens of $L$. afzelii have part of the outer layer of the shell surface eroded away. This is also the case for $L$. hansgei, a species where especially the protoconch is exposed to erosion. Almost $90 \%$ of specimens seen (both empty shells and live caught ones) had badly eroded protoconchs.

\section{Rissopsetia Dell, 1956}

\section{Rissopsetia islandica Warén, 1989 Figures 90-91}

\section{Rissopsetia islandica sp.n. Warén 1989:24 \\ Rissopsetia cf. islandica Warén - Høisæter 2009}

Type material: Holotype and several paratypes, SMNH 3897 and 3898.

Type locality: Skeidarardypi, off Vatnajökull, southeastern Iceland.

Material seen: Norway - Troms, upper slope, 1 shell.

Diagnosis: Shell: Almost cylindrical shell with distinctly convex whorls and deep sutures. $1.9 \mathrm{~mm}$ with four whorls. No visible sculpture. No visible columellar fold. Protoconch at roughly $130^{\circ}$ and mostly submerged in first teleoconch whorl. Protoconch of same type as in Chrysallida sublustris. Soft parts: Not known. Operculum: Not known.

Biology: Not known.

Distribution: In my material a single, slightly broken, shell from Bleiksdjupet northwest of Andøya, $\left(69^{\circ} 25^{\prime} \mathrm{N}, 200-700 \mathrm{~m}\right.$, stones and clay). $R$. islandica was described from southeastern Iceland, and reported also from western and southern Iceland in 200-570 m, and southeastern Greenland, 900 m (Warén 1989).

Remarks: Warén (in litt 2008) confirms that, based on living material, his species is indeed a pyramidellid. My shell from the upper slope near Andøya may be of the same species, 

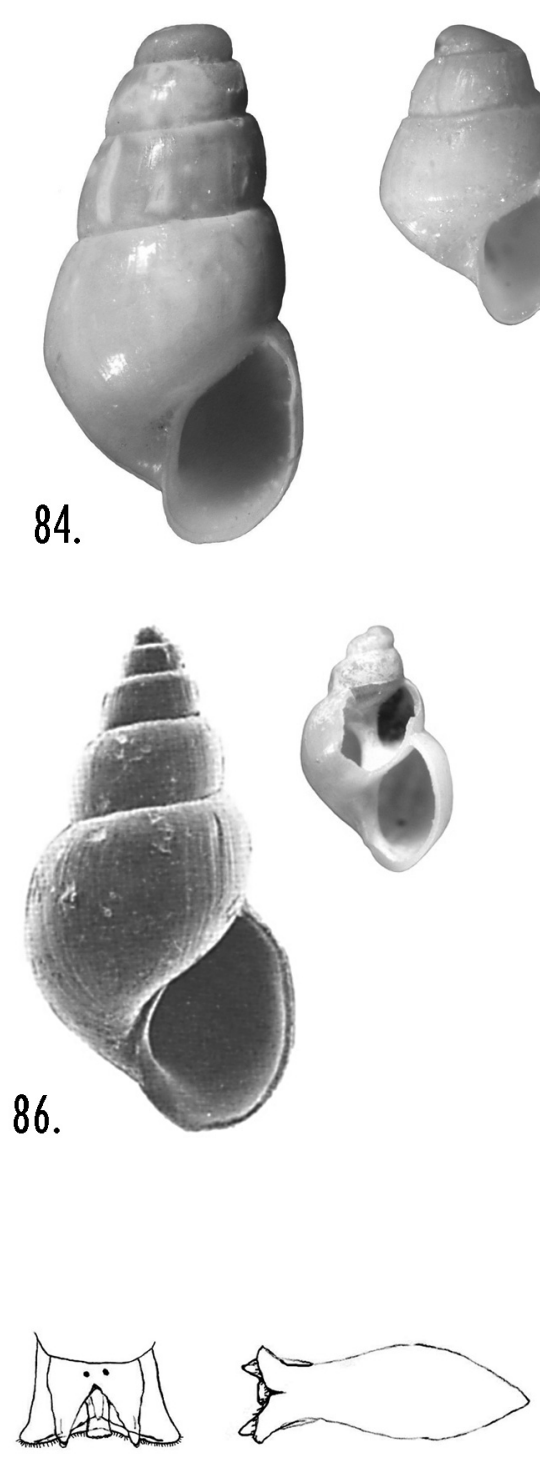

88.

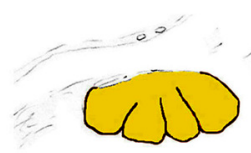

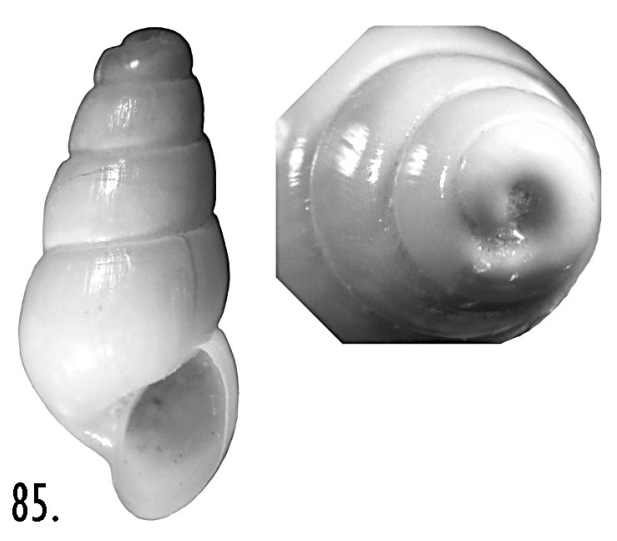
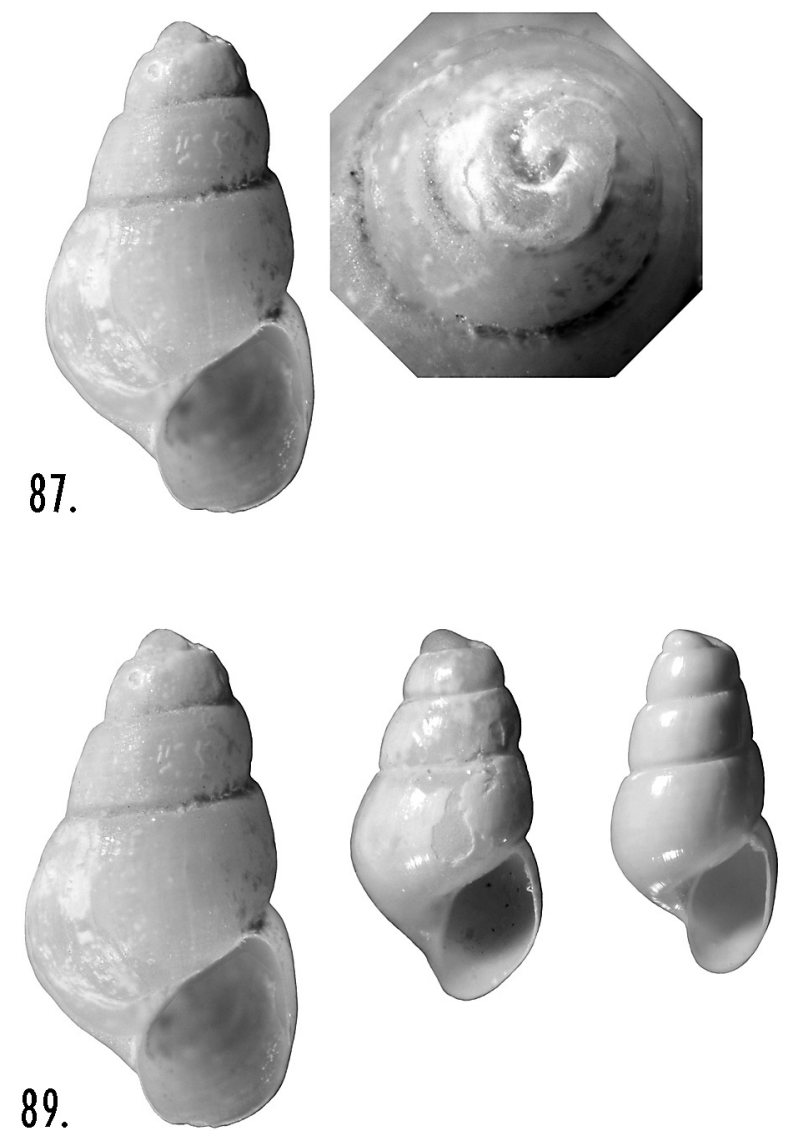

Figure 84. Liostomia afzelii. A specimen from Fevikkilen, Grimstad, 58 22.1'N, 08²40.9’ E, 25 m, $1.9 \mathrm{~mm}$ (S 10-88) (left) and one from Bay outside Vaholmen, Grimstad, $58^{\circ} 20^{\prime} \mathrm{N}, 08^{\circ} 38.6^{\prime} \mathrm{E}, 40 \mathrm{~m}, 1.15 \mathrm{~mm}$ (G 123-71).

Figure 85. Liostomia clavula. A specimen from Haramsfjorden, $62^{\circ} 36.6^{\prime} \mathrm{N}, 06^{\circ} 17.2^{\prime} \mathrm{E}, 42 \mathrm{~m}, 1.85 \mathrm{~mm}$ (ZMBN 83262), and the protoconch of the specimen in Figure 86.

Figure 86. Liostomia eburnea. Two specimens from Varangerfjorden. Specimen at left, from Warén 1991, $4.6 \mathrm{~mm}$, the shell at right also from Varengerfjorden, $2.6 \mathrm{~mm}$ (ZMBN 28182).

Figure 87. Liostomia hansgei. A specimen from Fanafjorden, NW of Korsneset, $60^{\circ} 13^{\prime} \mathrm{N}, 05^{\circ} 14^{\prime} \mathrm{E}, 220-230 \mathrm{~m}, 2.25 \mathrm{~mm}$ (ZMBN 83265). Figure 88. Liostomia hansgei. Head-foot complex and pigmented mantle organ.

Figure 89. A specimen of (from left to right) L. hansgei Fanafjorden, NW of Korsneset, $60^{\circ} 13^{\prime} \mathrm{N}, 05^{\circ} 14^{\prime} \mathrm{E}, 220-230 \mathrm{~m}, 2.25 \mathrm{~mm}$ (ZMBN 83265), L. azfzelii from Fevikkilen, Grimstad, $58^{\circ} 22.1^{\prime} \mathrm{N}, 08^{\circ} 40.9^{\prime} \mathrm{E}, 25 \mathrm{~m}, 1.65 \mathrm{~mm}$ (S 10-88), and L. clavula from Frænafjorden (Møre og Romsdal), $62^{\circ} 50.3^{\prime} \mathrm{N}, 07^{\circ} 05.5^{\prime} \mathrm{E}, 62-50 \mathrm{~m}, 1.58 \mathrm{~mm}$ (ZMBN 83264). 
although the illustrated types (cf. Figure 91) have strong growth lines not seen in my specimen.

Aartsenia Warén, 1991

\section{Aartsenia candida (Møller, 1842)}

Figure 92

Amaura candida sp.n. Møller 1842:80

Type material: Several syntypes in ZMUC GAS-6 - GAS9; BMNH 1843.6.30 and SMNH 3843 (3812) (Schiøtte \& Warén 1992).

Type locality: West Greenland, not specified (Schiøtte \& Warén 1992).

Material seen: None.

Diagnosis: Shell: Large (reaching at least $9 \mathrm{~mm}$ ), with dominating body whorl, very low and inconspicuous columellar fold, aperture oblong. Soft parts: Not known. Operculum: Not known.

Remarks: The only Norwegian record of this large Arctic species is two shells from Karlsøy, Troms county $\left(70^{\circ} \mathrm{N}, 9-27\right.$ m) (Leche 1878, Warén 1991). As all other records of the species are from Greenland, Spitsbergen and the Russian Arctic (Barents, Kara and Laptev Seas, Kantor \& Sysoev 2006), and there are no reports from east Finnmark, where all other highArctic animals in Norway are found, the record is surprising. The hydrographic conditions around Karlsøy do not in any way favour an Arctic fauna (already in 1880 Patella vulgata was found on one of the islands). The presence of this species in Norwegian waters needs verification.

\section{Subfamily Turbonillinae Bronn, 1849.}

Pyramidellids with elongated, turreted shells, a single columellar 'tooth' and large exposed protoconch with its axis at more or less $90^{\circ}$ axis of the theleoconch.

Key to the genera of Turbonillinae, based on shell morphology

1a. Shell smooth, or with very fine spiral sculpture in addition to growth lines .2

1b. Shell with axial sculpture .3

2a. Shell long with numerous whorls Eulimella

2b. Shell small and smooth with shouldered whorls, planorboid protoconch, usually missing Bacteridium (Incertae sedis)

3a. Shell with only axial sculpture Turbonilla

3b. Shell with both axial and spiral sculpture ........ Pyrgiscus

\section{Eulimella Forbes \& McAndrew, 1846}

Type species, by original designation: Eulimella macandrei (Forbes, 1844) (See van Aartsen 1988 and Warén 1991).

Pyramidellids with elongated, slender, many-whorled shells. Shell usually white, semitransparent and polished, and smooth or with delicate lines of growth (and sometimes extremely fine spiral lirations). Columellar fold either absent or a very low and indistict thickening on the nearly straight inner lip. Protoconch medium-sized to large, either helicoid or planorboid, with an angle of inclination of $80^{\circ}$ to $130^{\circ}$. The protoconch base is fully exposed and the spire only slightly immersed in the teleoconch. Height of first postlarval whorl $110-205 \mu \mathrm{m}$. Ratio of diameter of protoconch to diameter of first postlarval whorl between 0.70 and 0.85 . Operculum lightly horn-coloured, thin and transparent with small excentric spire, and a narrow internal, spiral ridge.

For some reason, Dall \& Bartsch (1904) include among the generic characters the presence of two columellar folds ('teeth'). This misconception has been arrested by practically every later author, and it has caused no great problems for the taxonomists. For the European forms, Jeffreys (1884) distinguished between shells having a distinct columellar fold, and those without. Thus he described a species, Odostomia praelonga, that in every respect fits the diagnosis of Eulimella except for the presence of a distinct tooth on the columella. Monterosato (1884) and Fischer (1887) both regarded the absence of a columellar fold as an importent diagnostic character for this group. Nordsieck (1972) collected all elongated, unsculptured species with an exposed, heterostrophic protoconch in the subfamily Eulimellinae.

Recently the North European species of the genus were monographed by Warén (1991), who recognised three formerly described species, and introduced one new species, Eulimella ataktos. Van Aartsen (1994) reviewed all European species of the group. He followed G.O. Sars (1878) in separating $E$. compactilis from E. scillae, a decision disputed by Warén (1991). However van Aartsen did not mention Warén's E. ataktos. In this paper all five species are accepted, and a new species is added (Eulimella frielei) bringing the total for Norwegian waters to six species.

Key to the species of Eulimella, based on shell morphology

1a. Shell solid, porcellaneous, a perfect cone with flat whorls, suture very shallow, periphery distinctly angulated Eulimella scillae

1b. Shell flatsided, channeled suture, delicate translucent shell, periphery rounded .....Eulimella compactilis

1c. Shell different ..2

2a. Protoconch helicoid Eulimella laevis

2b. Protoconch more or less planorboid ....3 
3a. Shell extremely long and thin, protoconch helicoid at $135^{\circ}$ Eulimella frielei

3b. Shell different ...4

4a. Shell narrow, H/W ratio 2.8 to 3.0 with 7 whorls, whorls convex, protoconch planorboid Eulimella ventricosa

4b. As $E$. ventricosa, but $\mathrm{H} / \mathrm{W}$ ratio around 2.5 with 7 whorls Eulimella ataktos

\section{Eulimella laevis (Brown, 1827)} Figures 93-94

\section{Pyramis laevis Brown, 1827:pl. 50}

Eulimella laevis (Brown) - Winckworth 1932; Ankel 1959; Fretter \& Graham 1962; Maas 1964; Rodriguez Babio \& Thiriot-Quièvreux 1974; McKay \& Smith 1979; Fretter et al. 1986; Høisæter 1986; Graham 1988; Smith \& Heppell 1991; Warén 1991; Schander et al. 2003

Melania acicula Philippi, 1836:158

Eulima acicula (Philippi) - Philippi 1844:135

Chemnitzia acicula (Philippi) - Alder 1848; Clark 1855

Odostomia acicula (Philippi) - Jeffreys 1848, 1867; M. Sars 1869, 1870; Jeffreys 1870; Friele 1874; Jeffreys 1884; Marshall 1900

Eulimella acicula (Philippi) - Forbes \& Hanley 1850-51; G.O. Sars 1878; Norman 1879; Petersen 1888; Grieg 1897; Kobelt 1903; Dautzenberg \& Fischer 1925; Thorson 1946; Nordsieck 1972; Rolan Mosquero 1983; van Aartsen 1994; Peñas et al. 1996; Høisæter 2009; Öztürk \& Bakir 2013

Turbonilla producta Lovén, 1846b:49 (not Jaminia producta C.B. Adams, 1839)

Eulimella commutata Monterosato 1884:98 - Ankel 1936; Ankel 1939

\section{Type material: Lost.}

Type locality: Shell sand from Dunbar, eastern Scotland.

Material seen: Norway - Skagerrak, 17 spms; Hordaland, 14 spms; Møre og Romsdal 17 spms; Nord-Trøndelag, 1 spm; Nordland, 7 spms; North Sea shelf, 1 juv. spm (84.05.25.6); England, 2 shs (ZMBN 15698).

Diagnosis: Shell: Eulimella with fairly elongate, almost cylindrical (sometimes somewhat cyrtoconoid) shell. Apical angle $18^{\circ}$ or less. Total shell length not exceeding $5 \mathrm{~mm}$. Number of postlarval whorls 9 or less. Shell rather solid, with fine spiral liration and fine sinuous, prosocline growthlines. Whorls slightly convex. Suture shallow. Protoconch helicoid, only slightly inclined $\left(90^{\circ}\right.$ to $\left.95^{\circ}\right)$. Soft parts: Head-foot complex shown in Figure 94. Tentacles wide and triangular. Eyes fairly large, placed at base of tentacles. Mentum wide, grooved dorsally and bifid terminally. The pigmented mantle organ is a complicated patchwork with white, black and gray parts, and dorsally with a small yellow 'stick' (Figure 94).
Operculum: Not studied.

Biology: Habitat mostly shell sand between 5 and $25 \mathrm{~m}$ depth, but no potential host animal known.

Distribution: In Norway it is found from Oslofjorden at least N to $67^{\circ} 16^{\prime} \mathrm{N}$ (Jeffreys 1870, M. Sars 1870, and G.O. Sars 1878). G.O. Sars (1878) records several specimens from Skudesnæs (c. $59^{\circ} 09^{\prime} \mathrm{N}$ ) which he presumably regarded as its northern limit. Friele (1874) and Norman (1879) later reported it from several stations near Bergen. Material from the University Museum of Bergen, shows that Friele had material from as far north as the classical locality Kinn outside Florø (c. $61^{\circ} 05^{\prime} \mathrm{N}$ ). In my material 35 specimens and an additional 65 shells from all along the coast north to outside Bodø $\left(67^{\circ} 16^{\prime} \mathrm{N}, 13 \mathrm{~m}\right.$, coarse shell gravel and Laminaria, one specimen and two shells). The abundance of this species increases from north to south, with a maximum in Møre og Romsdal (17 specimens and 22 shells), but only slightly less in the Espegrend area, with 14 specimens. My material from Skagerrak contained a similar number of specimens. Outside Norway it is reported as one of the more common species on the Swedish west coast (Lovén 1846a, Ankel 1939 and Maas 1964). In Danish waters it is reported from Skagen and south to the middle part of Øresund, where it appears to occur somewhat deeper than in more saline regions (Collin 1880, Petersen 1888 and Thorson 1946). McKay \& Smith (1979) report it from the North Sea coast of Scotland as well as from several localities in the northern North Sea. According to Fretter et al. (1986) it is a southern species ranging from the Black Sea, throughout the Mediterranean and north along the European coast to the British Isles and southern Norway. Peñas et al. (1996) confirm it from the western Mediterranean, and Öztürk \& Bakir (2013) as the most abundant species of Eulimella on the Turkish coast. According to van Aartsen et al. (2000) it is very rare in the Canary Islands and on the coast of Mauritania.

Remarks: Because of Jeffreys' insistence that $E$. ventricosa was only a variety of this species, the two species have been much confused in the faunistic literature until about 1880. The confusion was conclusively cleared up by G.O. Sars in 1878, and Jeffreys agreed in 1884. The name of this species has been much debated recently, although no one until 1875 , seemed to doubt that it should be E. acicula (Philippi). This name was given to a tertiary fossil from Sicily by Philippi in 1836, and was accepted by almost all authors as the name for the Recent form from the Mediterranean and the Atlantic coast of Europe. Winckworth (1932) discarded E. acicula, and resurrected the older E. laevis (Brown). Most later authors, especially those working with north and west European material, accepted this latter name. I have not seen a thorough discussion about why Winckworth rejected E. acicula, but presumably it was because the name of Brown was much older. Warén (1991) argues for the retention of Brown's name, Eulimella laevis for this group of north European pyramidellids. Smith \& Heppell (1991) also argues for keeping the oldest name, E. laevis. They state that the good descriptions in Brown (1844), based on the 
same specimens as illustrated in Brown (1827) eliminates any alternative conclusion. No other species could possibly stem from the sample (shell sand from Dunbar) from which the lost type specimen was taken. However van Aartsen (1994) preferred E. acicula as he argued that the name E. laevis is based on an unrecognisable miniature figure, which might not even be of a pyramidellid. Van Aartsen is not impressed by the redescription in Brown (1837) (the same as referred to as Brown 1844, by Smith \& Heppel 1991). Since E. laevis is the oldest name, based on a Recent shell from the North Sea and accepted by several recent authors from the region, this name is here used for the Norwegian specimens.

\section{Eulimella ataktos Warén, 1991}

Figures 95-96

\section{Eulimella ataktos n.sp. Warén, 1991:114}

Eulimella ataktos Warén - Schander 1995; Peñas et al. 1996; Høisæter 2009

Type material: Holotype SMNH 4100.

Type locality: Grøtsundet, Troms (c. $69^{\circ} 50^{`} \mathrm{~N}, 142-182 \mathrm{~m}$ )

Material seen: Norway - Hordaland, 1 spm (E 107-69b).

Diagnosis: Shell: Similar to E. ventricosa but wider, and adult specimens of the same size have one whorl less (Warén 1991). Soft parts: Not known. Operculum: Not known.

Biology: Not known.

Distribution: In Norway known from the holotype from Grøtsundet and a specimen from Nordre Brattholmen, Hjeltefjorden $\left(60^{\circ} 24^{\prime} \mathrm{N}, 100-180 \mathrm{~m}\right.$, gravel and coral rubble). In my material a specimen from Kobbeleia, east of Sotra $\left(60^{\circ} 18^{\prime} \mathrm{N}\right.$, $70 \mathrm{~m}$, fine sand, silt, Modiolula phaseolina gravel and small stones, coll. and leg. A. Warén), together with three specimens of $E$. ventricosa. Outside Norway a single shell reported from the Faroes (Schander 1995), and from between 150 and $300 \mathrm{~m}$ off Catalonia in Spain (Peñas et al. 1996).

Remarks: This species is not mentioned by van Aartsen (1994). Later (van Aartsen et al. 2000) listed several specimens from Cape Verde Islands as varieties of E. ventricosa ("..with planorboid protoconch, and smooth whorls with orthocline to slightly prosocline growth lines. Most of these shells are less slender than the European representatives of Eulimella ventricosa."). E. ataktos was not mentioned as a possible candidate. Two SEM photos in Peñas et al. (1996) agree reasonably well with my specimens. According to Warén (1991) $E$. ataktos is distinguished from E. ventricosa also by the colour of the soft parts, "the soft parts of dried specimens of $E$. ventricosa are flesh coloured with occasional patches of bluishblackish while those of E. ataktos are bright pink ." (Warén 1991:114). This is probably an unreliable character, as is evident from the soft part colour in the specimen in Figure 101 below. For comparison the top whorls of two shells of $E$. ventricosa are shown together with $E$. ataktos from the same sample (Figure
96). The question of whether E. ataktos is a valid species or only an extreme variety of $E$. ventricosa is still open.

\section{Eulimella compactilis (Jeffreys, 1867)}

Figure 97-98

Odostomia Scillae var. compactilis Jeffreys, 1867:169

Odostomia compactilis Jeffreys - Jeffreys 1884; Marshall 1893, 1900, 1917

Eulimella compactilis (Jeffreys) - G.O. Sars 1878; Locard 1899; Friele \& Grieg 1901; Kobelt 1903; Winckworth 1932; Fretter \& Graham 1962; Warén 1980; Fretter et al. 1986; Høisæter 1986; Smith \& Heppell 1991; van Aartsen 1994

Eulimella 'compactilis' (sensu G.O. Sars, 1878) - Høisæter 2009 Eulimella scillae (Jeffreys) - Warén 1991; Schander 1995 Odostomia scillae var. compactilis (Jeffreys) - Marshall 1894 Eulimella scillae var. compactilis (Jeffreys) - Ankel 1936 Eulimella superflua Monterosato - Nordsieck 1972

Type material: Lectotype (4.0 mm) USNM 132573 (van Aartsen 1994), Syntype NHMO D 997.

Type locality: Lofoten Islands, leg G.O. Sars.

Material seen: Norway - Norwegian Trench, 13 spms (83.11.17.5, 6130’N, $311 \mathrm{~m})$; Hordaland, 16 spms, 3 shs; Sogn og Fjordane, 1 spm (82.01.18.16), 1 sh (ZMBN 22819), Møre og Romsdal, 3 spms, 2 shs.

Diagnosis: Shell: Eulimella with fairly elongate, slightly cyrtoconoid shell. Apical angle $19^{\circ}$ or less. Total shell length not exceeding $5 \mathrm{~mm}$. Number of whorls eight or less. Shell delicate, thin, transparent, smooth with fine sinuous growth lines. Whorls evenly rounded or somewhat flattened. Body whorl evenly rounded below. Aperture higher than broad, flaring out below. Columellar fold not distinguishable. Protoconch large for genus (diameter about $320 \mu \mathrm{m}$ ), planorboid, only slightly inclined (angle of inclination about $90^{\circ}$ ). First postnuclear whorl around $180 \mu \mathrm{m}$ high. Soft parts: Not known. Operculum: Not known.

Biology: Not known, but the species seems to be confined to the soft bottoms of our deeper fjords, with its upper depth limit at about 150 to $200 \mathrm{~m}$.

Distribution: G.O. Sars (1878) reports it from Lofoten, 350-750 $\mathrm{m}$, and also several specimens from the western coast of Norway. Friele \& Grieg (1901) reported a specimen from Vestfjorden $\left(c .68^{\circ} \mathrm{N}\right)$, but this turned out to be a fragment of what I have called Eulimella frielei n.sp. below. In my material several samples from Møre og Romsdal, of which only three specimens from Voldafjorden $\left(62^{\circ} 10^{\circ} \mathrm{N}, 650-690 \mathrm{~m}\right.$, soft bottom) were live caught. Otherwise fairly common in the deep fjords around Bergen (300-450 m) and in the Norwegian Trench, a total of 33 specimens. There are no verified records of this species outside Norwegian waters. There is a slight possibility that it is also found in deep water in the North Atlantic as well as in the Mediterranean, if the four records 
of Jeffreys (1884) from the Porcupine expedition (see also Marshall 1900), as well as the suggested synonymy with $E$. superflua Monterosato, 1875, is substantiated. Warén (1991) however, dismissed these four specimens as a mixture of three different species, probably undescribed.

Remarks: This species was introduced as a variety of $E$. scillae by Jeffreys in 1867 , based on two specimens dredged in the Hebrides. In 1878, G.O. Sars reported a form from Norwegian waters which he regarded as identical with Jeffreys' variety (after having conferred with Jeffreys). G.O. Sars argued strongly for the recognition of this form as a separate species. In the material from the Porcupine expeditions, Jeffreys found four additional specimens of what he regarded as this form, and influenced by these new finds in addition to the work of G.O. Sars, Jeffreys (1884) recognized it as specifically distinct from E. scillae. Marshall $(1893,1900,1918)$ accepted it as a valid species, and mentioned a handful of shells from west of the British Isles and Ireland.
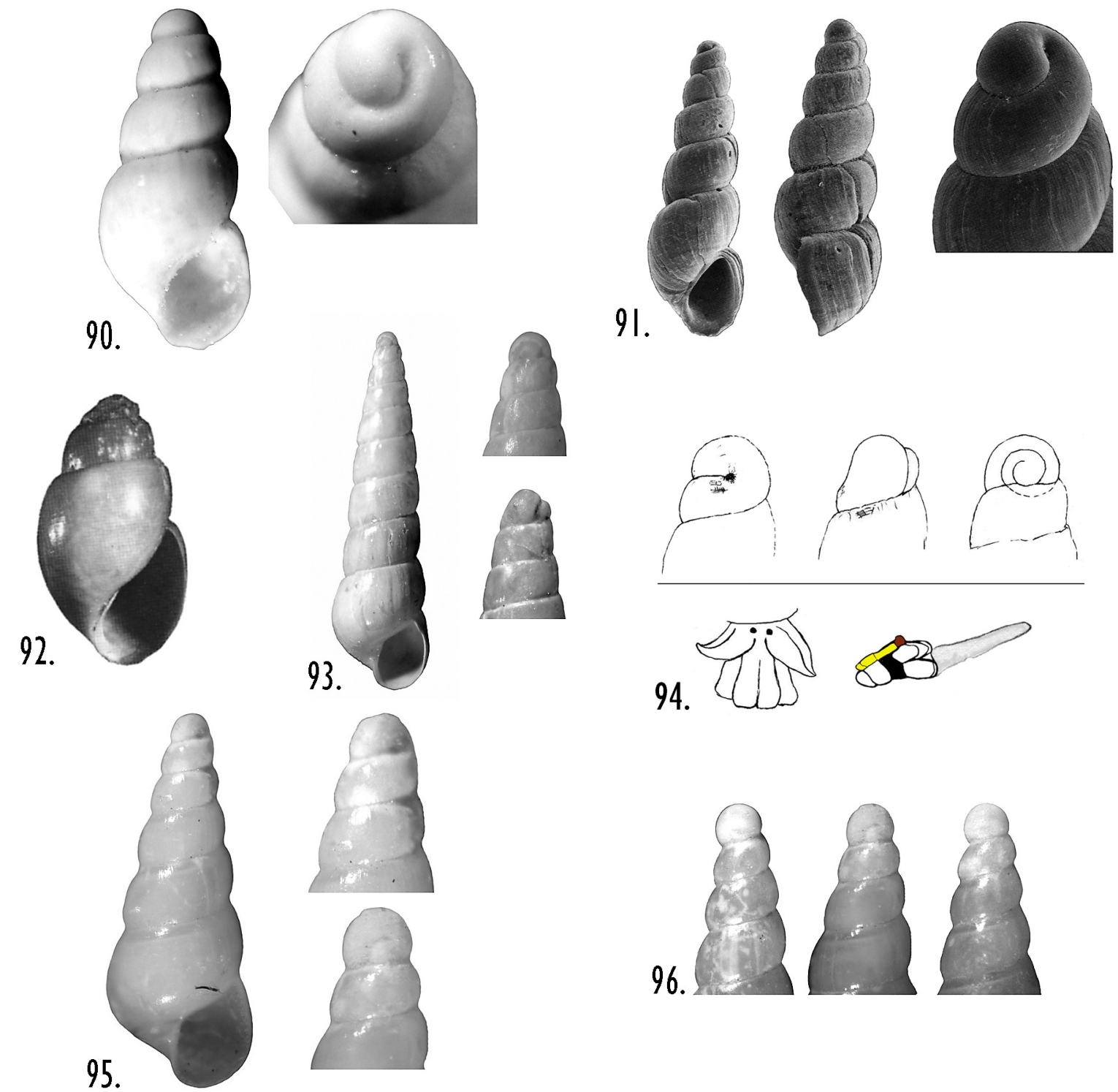

Figure 90. Rissopsetia $\mathrm{cf}$. islandica. A shell from Bleiksdjupet northwest of Andøya, $69^{\circ} 25^{`} \mathrm{~N}, 700-200 \mathrm{~m}, 1.9 \mathrm{~mm}$ (Ast 5256). Figure 91. Rissopsetia islandica. Types, 2.70 and $2.77 \mathrm{~mm}$ long. (SEM, from Warén 1989).

Figure 92. Aartsenia candida. Syntype, western Greenland (SMNH 3812) $7.0 \mathrm{~mm}$. From Warén (1991).

Figure 93. Eulimella laevis. (S 17-88, near Kragerø, SE of Portør 5847’N, 09²9’E, 60 m, 4.25 mm (S 17-88).

Figure 94. Eulimella laevis. Three orientations of protoconch, head-foot complex, and pigmented mantle organ.

Figure 95. Eulimella ataktos. Specimen from Kobbeleia, east of Sotra, 60¹7.7’N, 0508.7’E, 70 m, $2.2 \mathrm{~mm}$ (ZMBN 82902).

Figure 96. Top whorls of two specimens of E. ventricosa flanking one of E. ataktos, all from the same sample as the specimen in Figure 92 above (ZMBN 82902). 

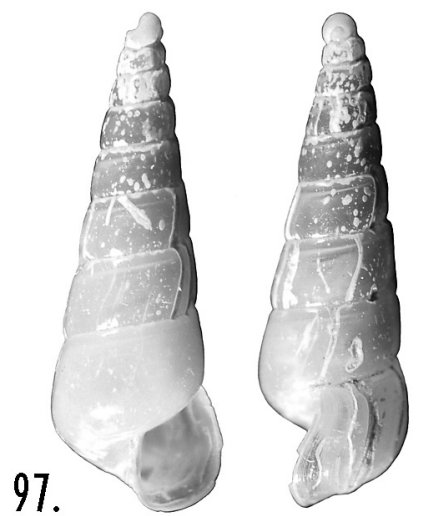
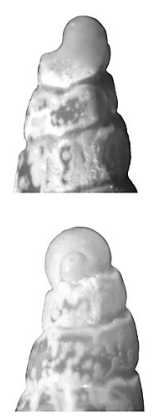
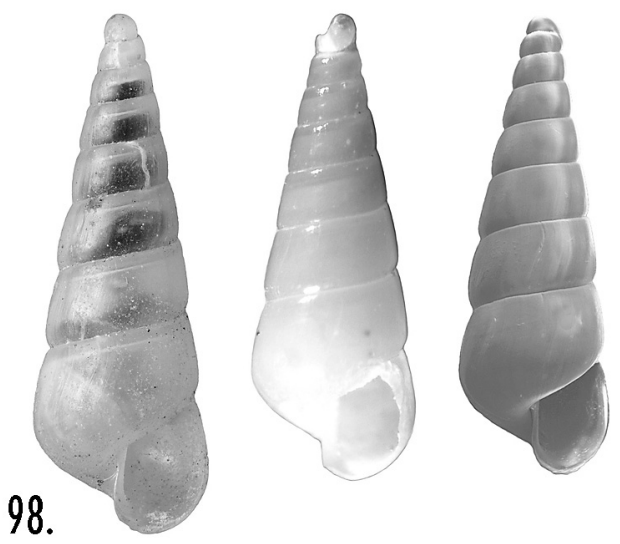

Figure 97. Eulimella compactilis. Specimen from outer part of Fanafjorden, silt w/gravel and much Saccammina-Rhabdammina, A. Warén, $60^{\circ} 13.5^{\prime} \mathrm{N}, 05^{\circ} 14.3^{\circ} \mathrm{E}, 185-200 \mathrm{~m}, 4.3 \mathrm{~mm}$ (ZMBN 82890).

Figure 98. Eulimella compactilis. Three specimens, from left: a syntype (one of 18) from Lofoten (NHMO D 997), $4.0 \mathrm{~mm}$; Fanafjorden, NW of Korsneset, $60^{\circ} 13^{\prime} \mathrm{N}, 220-230 \mathrm{~m}$ mud w/gravel and foraminiferans, leg. A. Warén; Norwegian Trench $61^{\circ} 30^{\prime} \mathrm{N}, 02^{\circ} 00^{\prime} \mathrm{E}, 311 \mathrm{~m}$, $3.45 \mathrm{~mm}(\mathrm{SEM})$.

The form Jeffreys named as a variety of $E$. scillae from the Hebrides is probably not identical to the material reported from Lofoten by G.O. Sars. Based on his material from Lofoten, G.O. Sars is positive that the specimens he studied are specifically separate from E. scillae. Warén (1980) found that the syntype from the Hebrides in thr USNM is a shell of E. laevis, and proposed to select the specimen from Lofoten donated to Jeffreys and today found in USNM, as lectotype for the species as this decision will conserve the name. Van Aartsen (1994) followed this suggestion and formally designated this specimen (USNM 132573) as lectotype of E. compactilis (Jeffreys, 1867). Warén (1991) claims that the specimens determined by G.O. Sars in the Natural History Museum, University of Oslo, are juveniles of E. scillae. After having compared my material with one of the (18) syntypes of G.O. Sars' (Figure 98 left) I am convinced that it is a good species, distinguished among other things, from E. scillae by its protoconch (cf. Figures 97 and 99). Figure 98 shows specimens from respectively Lofoten $\left(68^{\circ} \mathrm{N}\right)$, Fanafjorden $\left(60^{\circ} 13^{\prime} \mathrm{N}\right)$ and the Norwegian Trench $\left(61^{\circ} 30^{\circ} \mathrm{N}\right)$.

\section{Eulimella scillae (Scacchi, 1835)}

Figures 99-100

\section{Melania Scillae Scacchi, 1835:15}

Turbonilla Scillae (Scacchi) - Lovén 1846a, b

Eulimella Scillce (Scacchi) - Forbes \& Hanley 1850-51; McAndrew \& Barrett 1856; G.O. Sars 1878; Norman 1879; Petersen 1888

Eulimella scillae (Scacchi) - Grieg 1888; Norman 1892; Appellöf 1897; Grieg 1897, 1898; Friele \& Grieg 1901; Kobelt 1903; Nordgaard 1913; Grieg 1913, 1914; Ankel 1936; Nordsieck 1972; McKay \& Smith 1979; Fretter et al. 1986; Høisæter 1986; Graham 1988; Smith \& Heppell 1991; Warén 1991; van Aartsen 1994; Schander 1995; Peñas et al. 1996; Høisæter 2009; Öztürk \& Bakir 2013

Chemnitzia Scillae (Scacchi) - Clark 1855

Odostomia Scilloe (Scacchi) - Jeffreys 1848, 1867, 1870; Friele 1874; Jeffreys 1884; Marshall 1900

Odostomia (Eulimella) Scillee (Scacchi) - Monterosato 1875

Eulima MacAndrei Forbes, 1844: 412

Eulimella macandrei (Forbes) - Winckworth 1932

Eulimella macandrewi (Forbes) - Iredale 1915

Chemnitzia macandrei (Forbes) - Alder 1848

Eulimella crassula (Forbes, 1843) - Jeffreys 1846b

\section{Type material: Not known.}

Type locality: Upper Pliocene, around Gravina da Puglia, Italy.

Material seen: Norway - Skagerrak, 2 spms; Hordaland, 15 spms, 1 sh; Sogn og Fjordane 9 shs (ZMBN 1037, 20394, 21658); Møre og Romsdal 4 shs; Nord-Trøndelag, 1 spm, 21 shs; Nordland, 7 spms, at least 4 shs; Barents Sea, off Troms, 6 shs (ZMBN 21659).

Diagnosis: Shell: Eulimella with fairly elongate, slightly cyrtoconoid shell. Total shell length not exceeding $12 \mathrm{~mm}$. Number of whorls 12 or less. Shell with no visible sculpture, solid, nearly opaque, with a bluish-white hue, smooth but with fine, nearly straight growth lines and some extremely fine striations seen only at high magnification. Whorls almost flat. Body whorl distinctly angulated below, most pronounced in young specimens. Aperture trapezoid. Columellar fold detectable as a slight thickening on the inner lip. Protoconch large for the genus, helicoid, only slightly inclined. Soft parts: Tentacles triangular, tapering to narrow points, mentum slightly bifid, eyes fairly far apart. Pigmented mantle organ long and narrow, yellow with orange blotches (Figure 100). Operculum: Thin and translucent, with a narrow internal, spiral ridge, and 
without notch for columallar tooth.

Biology: Not known, but this characteristic species is found mainly in intermediate depths, from roughly 20 to $150 \mathrm{~m}$. The substrate is often a mixture of silt and shell gravel. However, it has also been reported from greater depths, with clayey bottom sediments. Many of the specimens are from hauls taken up steep rocky slopes with silty ledges.

Distribution: In Norway it is reported from Oslofjorden (Jeffreys 1870) at least N to $68^{\circ} \mathrm{N}$ (G.O. Sars 1878). Friele \& Grieg (1901) report it from the shelf (Tromsøflaket) at $71^{\circ} \mathrm{N}$. It is reported in almost every faunistic investigation from the western coast of Norway. In my material 13 specimens and an additional 55 shells. Three samples with two specimens and one shell in the material from Skagerrak, and six specimens from four samples in the material from Nordland. Nine samples with 11 specimens from the Bergen area, most of them collected by A. Warén. From the five cruises, at least 24 shells, but only two specimens, one from Bindalsfjorden (c. $65^{\circ} 10^{\prime} \mathrm{N}$ ) and one from Foldafjorden (c. $\left.64^{\circ} 40^{\prime} \mathrm{N}\right)$. The species seems to be fairly evenly distributed along the coast. Outside Norway, Petersen (1888) reports it from three places in the eastern Kattegatt, McKay \& Smith (1979) report it sparingly (only old records) from the North Sea coast of Scotland. It is also recorded from more southern parts of the British North Sea coast (Alder 1848, Jeffreys 1867, and Ankel 1936). Fretter et al. (1986) state that it is known from the Mediterranean, Madeira, the Canaries north to Arctic Norway. In the British Isles from the northern and western coasts, but not from the Channel or southern North Sea. Recorded by Peñas et al. (1996) from the western Mediterranean, Öztürk \& Bakir (2013) from the Turkish coast, and by van Aartsen et al. (2000) from Mauritania.

Remarks: E. scillae is based on an upper Pliocene fossil from southern Italy. The Recent shell was described as Eulima macandrei Forbes, 1844. The first to use the name of the fossil for the Recent material was apparently Jeffreys (1848), and his opinion has been accepted by almost every author since. According to Warén (1991) the deposits in which the original $E$. scillae was found, contained also a number of shells identical or very similar to Recent shells from intermediate depths in the Mediterranean and further north. This species is fairly common, and since it is one of the more conspicuous of the Norwegian species, it is perhaps the one species most frequently reported from Norwegian localities.

\section{Eulimella ventricosa (Forbes, 1844)}

Figures 96, 101-102

\section{Parthenia ventricosa Forbes, 1844:188}

Odostomia acicula var. ventricosa (Forbes) - Jeffreys 1867, 1869, 1870; Friele 1874

Odostomia (Eulimella) ventricosa (Forbes) - Monterosato 1875 Odostomia (Anisocycla) ventricosa (Forbes) - Monterosato 1880 Eulimella ventricosa (Forbes) - G.O. Sars 1878; Grieg 1888,
1897, 1898; Norman 1892; Friele \& Grieg 1901; Kobelt 1903; Grieg 1913; Grieg 1914; Nordsieck 1972; van Aartsen \& al. 1984; Fretter et al. 1986; Graham 1988; Smith \& Heppell 1991; Warén 1991; van Aartsen 1994; Schander 1995; Peñas et al. 1996; Høisæter 2009; Öztürk \& Bakir 2013

Odostomia ventricosa (Forbes) - Jeffreys 1884; Marshall 1893, 1900

Anisocycla ventricosa (Forbes) - Monterosato 1884

Eulimella gracilis sp.n. - Jeffreys, 1847:311

Eulimella gracilis Jeffreys - Winckworth 1932; Fretter \& Graham 1962; Rodriguez Babio \& Thiriot- Quièvreux 1974;

McKay \& Smith 1979; Warén 1980; Høisæter 1986

Chemnitzia acicula (Philippi) (in part) - Clark 1855

Eulimella affinis (Philippi) - Forbes \& Hanley 1850-51 (not

Eulima affinis Philippi, 1844); McAndrew \& Barrett 1856

Odostomia affinis (Philippi) - Jeffreys 1848

Eulimella polita? (Verrill, 1872) - Verrill 1882

Eulimella commutata var. ventricosa (Forbes) - Ankel 1936

Type material: Not known.

Type locality: Aegean Sea.

Material seen: Norway - Skagerrak, 4 spms, 1 sh; Norwegian Trench $\left(85.01 .08 .1,62^{\circ} 31.5^{\prime} \mathrm{N}, 701 \mathrm{~m}\right), 4$ spms; Hordaland, 13 spms, 24 shs; Sogn og Fjordane 7 spms, 12 shs (ZMBN 1035, 1036, 15685); Møre og Romsdal, 7 spms, 12 shs; Nord-Trøndelag, 63 shs; Nordland, 1 spm, at least 30 shs; Troms: 2 shs (ZMBN 21655); Ast. st. 78, 17/9-1970, 5 shs.

Diagnosis: Shell: Eulimella with fairly elongate, slightly cyrtoconoid shell. Total shell length not exceeding $6 \mathrm{~mm}$. Number of whorls 10 or less. Shell delicate, thin, completely transparent, smooth with fine sinuous growth lines. Whorls convex and evenly rounded. Body whorl evenly rounded. Columellar fold hardly visible. Protoconch (Figure 102 top) large for genus, planorboid, only slightly inclined. Soft parts: Tentacles short, triangular, pointing laterally. Mentum long and narrow, dorsally grooved and bifid in front. Front end of foot slightly bifid. Eyes rather small (Figure 102 bottom). Pigmented mantle organ an elongated white 'bar' followed by a series of disjointed white, dark brown and yellow spots and blotches (Figure 102 bottom). Elongated batch of orange in area behind pigmented organ proper. Operculum: Not studied.

Biology: Not known. Mostly found somewhat deeper than E. laevis, although both are occasionally found in the same samples.

Distribution: In Norway found from Oslofjorden (Jeffreys 1870) $\mathrm{N}$ to $68^{\circ} \mathrm{N}$ (G.O. Sars 1878), and $71^{\circ} \mathrm{N}$ (Friele \& Grieg 1901). Probably the commonest Eulimella-species on the Norwegian coast, and known as far north as the southern Barents Sea $\left(70^{\circ} 55^{\prime}\right.$ N, Friele \& Grieg 1901). In my material one specimen and one shell from Skagerrak, 24 specimens and an additional 125 shells from further north, the northernmost specimen is from a sample from outside Kristiansund $\left(63^{\circ} 09^{\prime} \mathrm{N}\right.$, $145 \mathrm{~m}$, sand), and the northernmost shell from the upper slope northwest of Andøya $\left(69^{\circ} 25^{\prime} \mathrm{N}, 700-200 \mathrm{~m}\right.$, clay mixed 
with fine sand and some stones). Outside Norway reported by McKay \& Smith (1979) as rare on the Scottish North Sea coast, and by Fretter et al. (1986) as confined to northern and western Scotland, only empty shells found further south on the west coasts of the British Isles. Absent from the North Sea and from Danish and Swedish waters. Otherwise found scattered from the Mediterranean (e.g. the Turkish coast, Öztürk \& Bakir 2013), and northwards along the European coast (Fretter et al. 1986 and Peñas et al. 1996). Also found in the Canary Islands (van Aartsen et al. 2000).

Remarks: Long regarded (on the authority of Jeffreys) as a variety of $E$. laevis. However, in addition to the convincing arguments of G.O. Sars (1878) for recognizing it as a valid species, the very distinct protoconch (Figure 105 right, and Rodriguez Babio \& Thiriot-Quiévreux 1974) should remove the last vestiges of doubt. The name has received some competition from E. affinis (Philippi, 1844), and E. gracilis (Jeffreys, 1847) (see e.g. Jeffreys 1884:363, Warén 1991 and van Aartsen 1994). Some problems still remain concerning its distinctness from $E$. ataktos (see above).

\section{Eulimella frielei n.sp.}

Figure 103-105

\section{Odostomia acicula (Philippi, 1836) - Friele, 1876:6}

LSID: urn:Isid:zoobank.org:act:726A8344-7889-493AA882-2CC7D068E623

Type material: Holotype ZMBN 1044.

Type locality: Korsfjorden, western Norway, $360 \mathrm{~m}$.

Etymology: Named after the well known malacologist, Herman Friele, who originally identified the shell, here designated as the holotype under the name Odostomia acicula (Friele 1876).

Material seen: Norway - Hordaland, 1 sh (ZMBN 1044, Holotype); Nordland, 2 shs (T 71064 \& ZMBN 21657).

Diagnosis: Shell: Eulimella with extremely long and narrow shell. Apical angle c. $11^{\circ}$. Total shell length of holotype $11 \mathrm{~mm}$. Seventeen whorls in holotype. Shell delicate, thin, transparent, with distinctly sinuous, opisthocline growth lines (Figure 104). Shell otherwise smooth and glossy, no sculpture except very indistinct, fine spiral incisions. First c. six whorls convex, evenly rounded. Next several whorls almost flat. Later whorls gradually more and more pear-shaped, with widest diameter at lower end. Body whorl with evenly rounded periphery, no angulation as in e.g. E. scillae. Aperture trapezoid, columellar lip straight. Columellar fold absent. No umbilicus. Protoconch (Figure 103, right) planorboid, but with distinct bulging top whorl, slightly inclined, intermediate between, E. ventricosa and E. laevis (Figure 105). Soft parts: Not known. Operculum: Not known.

Biology: Not known.

Distribution: (See Remarks below).
Remarks: A specimen in the Zoological Museum, University of Bergen (ZMBN 1044), from Korsfjorden, $\left(60^{\circ} 10^{\prime} \mathrm{N}\right) 360 \mathrm{~m}$, identified as Odostomia acicula $\mathrm{Ph}$. by Friele (Friele 1876:6), is unique in the Norwegian fauna for its size. Seventeen whorls and a length of $11 \mathrm{~mm}$ is far more than for any other species of Eulimella. Friele ascribed it to the variety turris of Forbes. "Shell of nearly equal breadth throughout, with rather convex whorls" Jeffreys 1867:171. Whether the shell from Korsfjorden is conspecific with the variety turris from the Aegean Sea is doubtful. Van Aartsen (1994:97) mentions this variety briefly "The species Parthenia turris Forbes, 1844 cannot be recognized with any certainty and is therefore considered a nomen dubium". It is tricky to base the description of a new species on so little material, but the extreme length, the sinuous opisthocline growth lines, the distinctive protoconch and the characteristic shape of the individual whorls, clearly keep it apart from any other species described from European waters.

\section{Turbonilla Risso, 1826 ex Leach ms}

Type species, by subsequent designation: Turbonilla costulata Risso, 1826; designated by Herrmannsen (1852). Mediterranean fossil.

Pyramidellids with elongate, slender, conical or cyrtoconoid, many-whorled shells. Sculpture consisting of strong axial ribs, without or with only microscopical spiral ornamentation. Shell white or semitransparent. Columellar fold only as a slight thickening on the inner lip. Protoconch of type A (helicoid, its axis at an angle of $90^{\circ}$ to the main shell axis) or type B (planorboid, its axis at an angle of roughly $135^{\circ}$ to the main shell axis).The protoconch is (usually) largely exposed, with the whole of its base visible and only part of the spire immersed in the teleoconch. Height of first teleoconch whorl, 200-280 $\mu \mathrm{m}$. Operculum horncoloured, thin and translucent, with a small, excentric spire and without any 'anchor' or internal process.

Turbonilla was created by Leach in an ms written before 1818, but not published until 1846 (see Lovén 1846a). He intended the name to be used for a group of small shells superficially resembling Turritella. The name was validated by Risso who, in 1826, used the name for three fossil and one recent Italian pyramidellids: Turbo gracilis Brocchi, 1814, Turbonilla plicatula Risso, 1826, T. costulata Risso, 1826, and T. humboldtii Risso, 1826. According to Palmer (1958), the type species (by subsequent designation of Herrmannsen 1852), is the fossil, Turbonilla costulata. This species was regarded by most workers in the $19^{\text {th }}$ century (e.g. Monterosato 1884) as a synonym of Turbo elegantissima (Montagu, 1803), and the adoption of this species as genotype was certainly in the spirit of Leach. Dall \& Bartsch (1904) apparently was unaware of this type designation, as they, without comments, lists T. plicatula (erroneously spelled T. plicata in their 1909-work) as type, but 

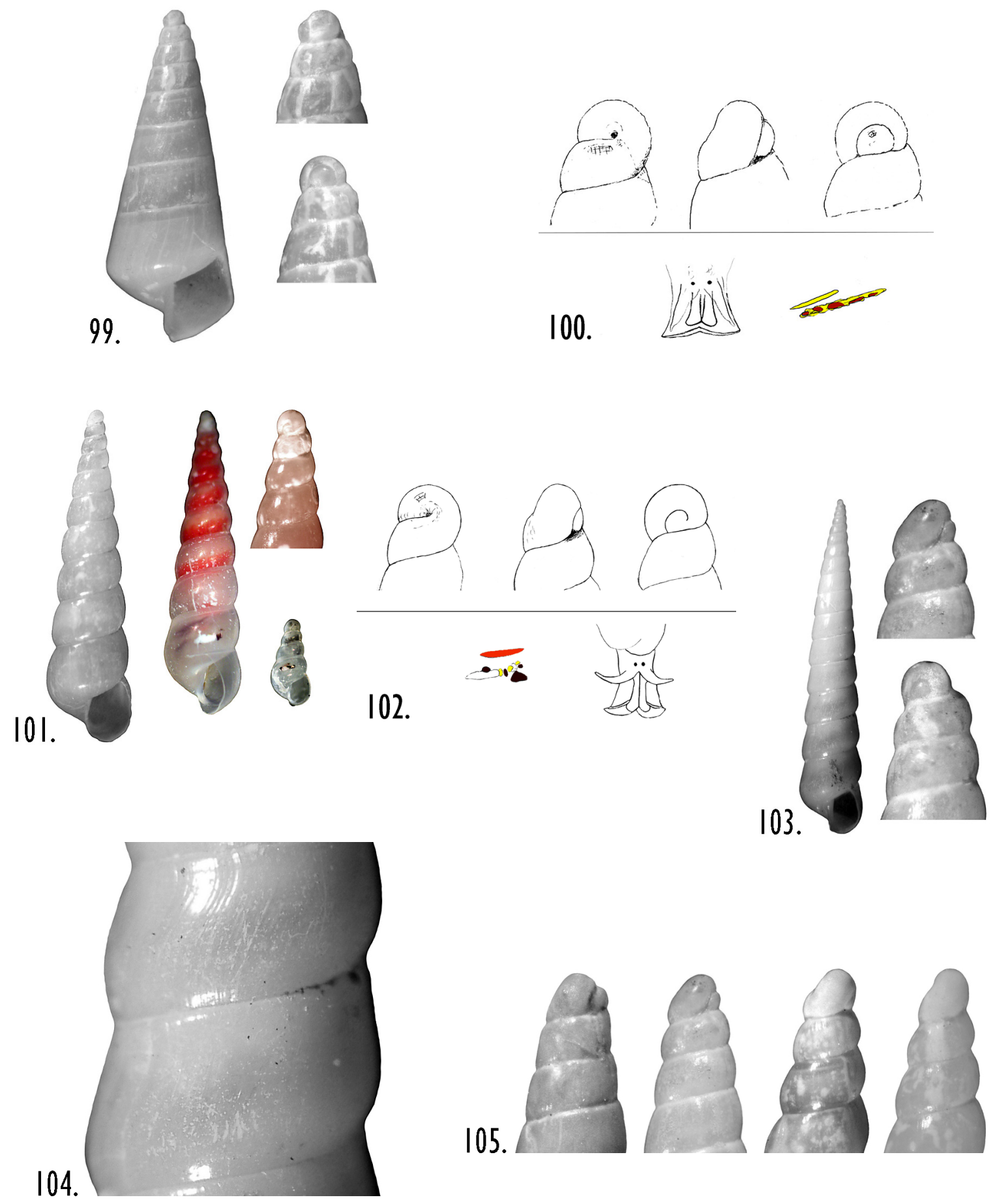

Figure 99. Eulimella scillae. Specimen from between Songvår and Hellesøy, Søgne (Vest-Agder), 5801'N, 0749’E, 75-70 m, $4.2 \mathrm{~mm}$ (S 47-88).

Figure 100. Eulimella scillae. Three orientations of protoconch, head-foot complex, and pigmented mantle organ.

Figure 101. Eulimella ventricosa. At left a specimen from Skagerrak SE of Store Torungen, (Aust-Agder) $58^{\circ} 22^{\prime} \mathrm{N}, 08^{\circ} 50.2^{\prime} \mathrm{E}, 79 \mathrm{~m}, 5.0 \mathrm{~mm}$

(S 4-86), and at right two specimens from Kobbeleia, Raunefjorden, 60 $17.7^{\prime} \mathrm{N}, 05^{\circ} 08.7^{\prime} \mathrm{E}, 70-90 \mathrm{~m}, 4.75 \mathrm{~mm}$ and $1.3 \mathrm{~mm}$ (2007-1). Figure 102. Eulimella ventricosa. Three orientations of protoconch, pigmented mantle organ, and head-foot complex of crawling snail. Figure 103. Eulimella frielei n. sp. Holotype (ZMBN 1044).

Figure 104. Eulimella frielei $\mathrm{n} . \mathrm{sp}$. Holotype. Detail of shell showing growth lines.

Figure 105. Top whorls of four specimens of Eulimella, from left: E. laevis, E. frielei n.sp. and two specimens of E. ventricosa. 
at the same time renaming the species T. typica, as they found T. plicatula preoccupied. Winckworth (1932) correctly cites $T$. costulata as type species, but most modern authors (e.g. Bartsch 1955, and Abbott 1974) uses one of the following names: $T$. typica, T. plicata, or T. plicatula. Bush (1899), Thiele (1929), and Nordsieck (1972) all use T. lactea as genotype, however.

Like many of the early genera in the Pyramidellidae, Turbonilla has been used both in a broad and in a narrow sense. In the broad sense it encompass all elongated species with a large, exposed protoconch and distinct axial sculpture (see e.g. G.O. Sars 1878, and Fischer 1887), a group that, especially in temperate and warm waters, exhibit a tremendous diversity. Dall \& Bartsch (1904) adopted the name for an even broader group of shells, cylindro-conic, many-whorled, slender pyramidellids with a single columellar fold, with or without sculpture. The name was used in much the same sense by Kobelt (1903), though he was less categorical about the presence of a columellar fold. Thiele (1929), van Aartsen (1981) and Fretter et al. (1986) all use Turbonilla in the sense of G.O. Sars. In this review, the name is used in a narrower sense, only for pyramidellids with an elongated, many-whorled shell with axial sculpture (no spiral ornamentation), and an exposed protoconch.

Turbonilla sensu stricto is not a northern group. Only two species are treated here, one of those only because of some, probably erroneous, records from the $19^{\text {th }}$ century.

Key to the species of Turbonilla, based on shell morphology

1a. Protoconch planorboid with $135^{\circ}$ to the shell axis ...Turbonilla lactea

1b. Protoconch helicoid with $90^{\circ}$ to the shall axis .Turbonilla pusilla

\section{Turbonilla lactea (L., 1758)}

Figure 106

\section{Turbo lacteus L., 1758:1238}

Odostomia lactea (L.) - Jeffreys 1848, 1867, 1884; Marshall 1900 (not O. lactea Friele 1874:18)

Odostomia (Turbonilla) lactea (L.) - Monterosato 1875

Turbonilla lactea (L.) - Kobelt 1903; Ankel 1936; Nordsieck 1972; van Aartsen 1981; van Aartsen \& al. 1984; Fretter et al. 1986; Smith \& Heppell 1991; Peñas et al. 1996; Schander et al. 2003; Öztürk \& Bakir 2013

Turbonilla (Chemnitzia) lactea (L.) - Dautzenberg \& Fischer 1925

Chemnitzia lactea (L.) - Petersen 1888

Turbo elegantissimus Montagu, 1803:298

Parthenia elegantissima (Montagu) - Thompson 1844

Chemnitzia elegantissima (Montagu) - Forbes \& Hanley 1850-

51; Clark 1855 (not C. elegantissima of M. Sars 1859)

Turbonilla elegantissima (Montagu) - Monterosato 1884;
Winckworth 1932; McKay \& Smith 1979; Høisæter 1986; (not T. elegantissima of Rodriguez Babio \& ThiriotQuièvreux 1975)

Type material: Linnaean collection in Uppsala.

Type locality: Mediterranean.

Material seen: British Isles - ZMBN 22253, 5 shs; ZMBN 28601, 3 shs; Ouisnè Bay, Jersey, 1 sh (leg. W. Vader 1968), Madeira - ZMBN 3607, 4 shs; ZMBN 3642, 1 sh.

Diagnosis: Shell: Turbonilla with fairly elongate, only slightly cyrtoconoid shell. Total shell length not exceeding 8.5 $\mathrm{mm}$. Number of whorls 13 or less. Whorls evenly rounded, only slightly convex. Shell, white, delicate, thin. Sculpture consisting of 18-22, strong axial ribs, slightly S-shaped, extending from the suture to a short distance below the periphery. No spiral sculpture. Columellar fold very slight and retracted. Protoconch almost planorboid of 2 to 2.5 whorls at an angle of about $135^{\circ}$ to the shell axis, its base completely exposed. Soft parts: Not known. Operculum: Not known.

Biology: "The snails suck fluid from the tentacles of such worms as Audouinia tentaculata and Amphitrite gracilis" (Fretter 1951). "Under stones and in crevices on muddy rocky shores at LWST, extending to 10 fathoms, on all coasts, Ireland; associated with Amphitrite gracilis, Cirratulus cirratus and Audouinia tentaculata. Breeding unknown" (Fretter \& Graham 1962, Fretter et al. 1986).

Distribution: Not confirmed from Norway. M. Sars (1859) reported this species from Tromsø, a record that has been widely quoted, but never verified. According to Norman (1879), a record by Friele $(1874)$ from Bergen $\left(60.5^{\circ} \mathrm{N}\right)$ was due to a mistake. The record of McAndrew \& Barrett (1856) of frequent observations between 40-100 fathoms on gravel in Nordland and Finmark, is most certainly due to misidentifications. G.O. Sars (1878:374) included this species as one of three pyramidellids that had been included in earlier check-lists, as doubtful or obvious misidentifications. Outside Norway reported by Petersen (1888) as living in Danish waters. Found as old shells, maybe fossils, around the Firth of Forth, Scottish North Sea coast, McKay \& Smith (1979). According to Fretter et al. (1986:634) "From the Mediterranean to northern Norway, but absent from Danish waters and from most of the North Sea; occasionally found off western British and Irish coasts". The present range of this species is almost certainly not extending as far north as the Norwegian coast, the frequent citations in the literature notwithstanding. However, the species seems to have been present in the Norwegian fauna in late postglacial times (Brögger 1901), and according to Petersen (1888), and Ankel (1936), it could still be part of the fauna in Kattegatt and the west coast of Sweden. As is evident from the citation from Fretter et al. above, the exact distribution limits of this species are hard to pinpoint due to the many misidentifications in the literature.

Remarks: There seems to be general agreement that the shells commonly called $T$. lactea by the continental authors and 
by Jeffreys, and the ones called T. elegantissima by the early British conchologists and Winckworth (1932), belong to the same species. The disagreement about the specific name stems from the uncertainty created by Linnaeus' sketchy description of his Turbo lacteus. Forbes \& Hanley (1850-51) recommend the use of T. elegantissima on these grounds. However, apparently based on Jeffreys (1867), both Nordsieck (1972), van Aartsen (1981), and Fretter et al. (1986) (and thus Graham 1988) use $T$. lactea. The arguments presented are not too detailed however (van Aartsen simply states: "I consider T. lactea identical with T. elegantissima (Mont.), and in view of priority use the name given by Linnaeus"). Schander (pers. comm to Hansson 1998) studied the types of Turbo lacteus in Uppsala, and found them to be a mixture of Rissoa parva and $R$. violacea. As Schander never made a formal decision on reintroducing T. elegantissima, I prefer to use the name generally accepted since the 1970ties.

\section{Turbonilla pusilla (Philippi, 1844)}

Figure 107

\section{Chemnitzia pusilla Philippi, 1844:124}

Turbonilla pusilla (Philippi) - van Aartsen 1981; van Aartsen \& al. 1984; Fretter et al. 1986; Graham 1988; Smith \& Heppell 1991; Peñas et al. 1996; Öztürk \& Bakir 2013

Turbonilla cf. pusilla (Philippi) - Høisæter 2009

Turbonilla innovata Monterosato, 1884 - Winckworth 1932

Turbonilla acuta (Donovan, 1804) - sensu Fretter et al. 1986; Graham 1988

Type material: Not known

Type locality: Palermo, Sicily.

Material seen: Norway - Skagerrak, 2 spms, 40 shs (around $58^{\circ} 17^{\prime} \mathrm{N}, 8^{\circ} 35^{\prime} \mathrm{E}$ ).

Diagnosis: Shell: Turbonilla with fairly elongate shell.
Total shell length rarely exceeding $5 \mathrm{~mm}$. Number of whorls 10 or less. Sculpture consisting of up to 25 slightly opisthocline, close set ribs. No spiral sculpture. Columellar fold very slight and retracted. Protoconch helicoid of 2.5 to 3 whorls at an angle of about $95^{\circ}$ to the teleoconch, its base completely exposed. Soft parts: Not known. Operculum: Not known.

Biology: Not known.

Distribution: Here reported from Norway for the first time, restricted to the Norwegian part of Skagerrak. Two specimens and 40 empty shells, all from localities close to Grimstad on the Skagerrak coast. All collected by Wikander 1970-1975. Outside Norway: "This is a southern species reaching its northern limits on the southern and western shores of the British Isles. Not found in the North Sea nor in Scandinavia" (Fretter et al. 1986:637). Possibly found in the Koster area in the Swedish part of Skagerrak (Warén in Hansson 1998). Otherwise reported from the Mediterranean where it is common (Peñas et al. 1996, Öztürk \& Bakir 2013).

Remarks: This member of Turbonilla s.s. has turned out to be not uncommon in the Skagerrak region. The correct name of the species is not easily determined. In the British Isles, at least four species names are, or have been, in use for members of this genus (see e.g. Smith \& Heppell 1991): T. lactea (L., 1758) (= T. elegantissima Montagu, 1803), T. acuta (Donovan, 1804), T. pusilla (Philippi, 1844), and T. pumila (G. Seguenza, 1876) (= T. innovata Monterosato, 1884). As most recent authors rely heavily on van Aartsen's (1981) opinion concerning this group, I compare my specimens to his detailed description. He distinguishes first of all between T. pusilla and T. lactea, of which the former has a protoconch like the specimens from Skagerrak (type A, helicoid, $90^{\circ}$ angle to the axis). T. lactea on the other hand, has a planorboid protoconch (type $\mathrm{B}, 135^{\circ}$ angle to the axis), which clearly distinguish it from his T. pusilla. T. pumila is a scarce shell in the Channel, and its protoconch is of the same type as T. lactea, and is thus out of the question. The
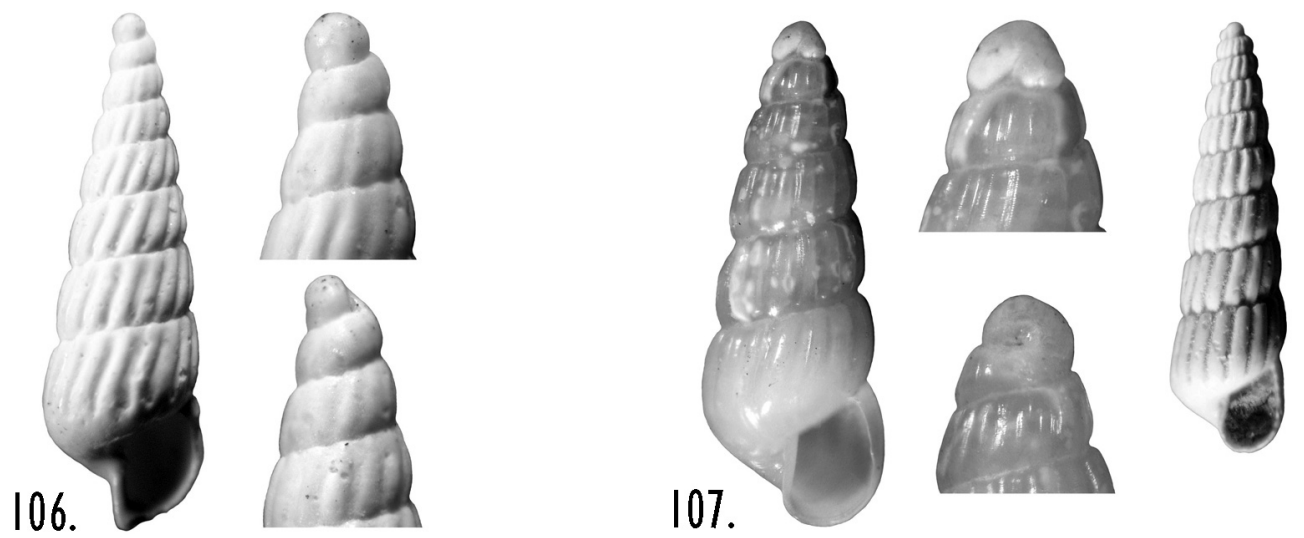

Figure 106. Turbonilla lactea. Shell from Ouisné Bay, Jersey, $3.8 \mathrm{~mm}$.

Figure 107. Turbonilla pusilla. Left, specimen from Grimstad, East Hesnesøy, 58²0.3'N, 08³9.4'E, 30-10 m, $2.5 \mathrm{~mm}$ (G 28-71); right, shell from Grimstad, $900 \mathrm{~m} \mathrm{~S}$ of Moysanden, 58²0.9’ N, 08²1.6’'E, 150-50 m, $4.1 \mathrm{~mm}$ (G 67-71). 
interpretation of $T$. acuta he finds difficult, but following the description of various recent British authors T. acuta should be a sister species to the purely Mediterranean $T$. delicata, with a type A protoconch, but with 3-5 of the uppermost turns in the first teleoconch whorls smooth, i.e. no axial ribs. On the remaining whorls, the ribs are broad and close together. Our Norwegian shells do not fit this description, neither do the drawings of T. acuta in Fretter et al. (1986, their figure 433). These are almost certainly conspecific with our Norwegian form (compare with Figure 107, right). I conclude that if I choose to follow van Aartsen (1981), T. pusilla is the most likely candidate, if I prefer Fretter et al. (1986), T. acuta is the correct name for our species. Unless the material from Skagerrak represent an undescribed species, $T$. pusilla (Philippi) $(=T$. acuta sensu Fretter et al. 1886) is by far the most likely name. Van Aartsen (1981) claims that T. pusilla is the commonest and most variable species of Turbonilla in Europe.

\section{Pyrgiscus Philippi, 1841}

Type species, by subsequent designation: Melania rufa Philippi, 1836; designated by Dall \& Bartsch in Arnold (1903:274). Recent, Mediterranean.

Pyramidellids with elongate, conical to cyrtoconoid, manywhorled shells. Sculpture consisting of strong axial ribs with spiral, incised lines in the intercostal grooves, no spiral sculpture crossing the axial ribs. Shell yellowish to reddish brown, sometimes with one to three darker bands round the periphery of each whorl. Columellar fold small to indistinct. Protoconch large, of type A or B. Operculum horny, translucent, thin, without any 'anchor' or internal process, only with a narrow curved list (Figure 112).

This group has traditionally been regarded as a subgenus of Turbonilla, but I consider the distinguishing characters sufficiently distinct to warrant full generic status. This conclusion is supported by the molecular study of Schander et al. (2003) and the morphology based cladistics analysis of Wise (1996). Regarding the nomenclatural history, this group has been blessed with more than its share of problems. Monterosato (1884) recognized 5 sections for the spirally sculptured "Turbonillas", and gave them all new generic names. In particular Pyrgostelis (genotype Melania rufa Philippi, 1836) and Pyrgisculus (genotype Melania scalaris Philippi, 1836), might both be used for our forms. Dall \& Bartsch (1904) largely retained Monterosato's principles for subdividing the genus Turbonilla s.l., but reintroduced a number of older names. Thus while Pyrgisculus was retained, they renamed Pyrgostelis as Pyrgiscus Philippi, 1841. Pyrgiscus was introduced by Philippi (1841) for four recent, Mediterranean shells he had described in 1836 as Melania spp.: M. rufa, M. campanellae, M. pallida, and M. scalaris. He did not list the spiral sculpture among the generic characters, and his inclusion of M. campanellae, which is a close relative to, if not conspecific with, Turbonilla lactea shows that he did not regard this as a character worthy of generic distinction. Furthermore, in a footnote, he stated that Risso in 1826 had erected the genus Turbonilla that largely corresponded to Pyrgiscus. Accordingly, most later authors automatically listed Pyrgiscus as a synonym of Turbonilla, until Dall \& Bartsch took advantage of the fact that no type species had been designated, reintroduced it as the subgeneric name for one of their striated Turbonilla's (see further Iredale 1915:338). Winckworth (1932) use Pyrgisculus Monterosato, 1884 (as a subgenus) with no further explanation. Van Aartsen (1981) and Fretter et al. (1986) use Turbonilla for all species, with or without spiral sculpture. Most recent authors however, use Pyrgiscus as an independent genus. Wharton (1976) suggests that Pyrgiscus may be distinguished from Turbonilla s.s. by the presence of denticles on the penis (as described by Maas 1964 on an unidentified species from the Mediterranean). Except for that I regard the large protoconch and the shell colour as good reasons for keeping the two groups apart. Recently (Schander et al. 2003) based on $16 \mathrm{~S}$ mitochondrial DNA-evidence, presented convincing arguments for placing Turbonilla and Pyrgiscus in different clades within the family. Incidentally, Wise (1996) introduced a new genus, Houbrickia, for a North American group with much the same morphological characteristics as our European Pyrgiscus.

Four 'species' are treated below although they are not all valid species of the Norwegian fauna. One of the 'species' might be a variety of one of the others, while one owes its inclusion to a confusion with a species only living on the Atlantic coasts of France and south into the Mediterranean.

\section{Pyrgiscus rufus (Philippi, 1836) Figure 108}

\section{Melania rufa Philippi, 1836:156}

Chemnitzia rufa (Philippi) - Clark 1855

Odostomia rufa (Philippi) - Jeffreys 1848, 1867; Marshall 1900 Turbonilla rufa (Philippi) - Van Aartsen 1981; Rolán Mosquera 1983; Peñas et al. 1996; Peñas \& Rolán 1997; Høisæter 2009; Öztürk \& Bakir 2013; CLEMAM 2014

Turbonilla (Chemnitzia) rufa (Philippi) - Malm 1861

Turbonilla (Pyrgostelis) rufa (Philippi) - Kobelt 1903

Turbonilla (Pyrgiscus) rufa (Philippi) - Nordsieck 1972

Pyrgiscus rufa (Philippi) - Schander et al. 2003

Turbonilla (Pyrgiscus) crenata (Brown) - Smith \& Heppell 1991 Turbonilla (Pyrgisculus) crenata (Brown) - Winckworth 1932

Type material: Not known.

Type locality: Magnisi, eastern Sicily.

Material seen: Norway - Skagerrak, 2 shs, Grimstad, Aust-Agder $\left(58^{\circ} 20^{\prime} \mathrm{N}, 8^{\circ} 40^{\prime} \mathrm{E}\right)$; Rogaland, $1 \mathrm{spm}$, Lysefjorden $\left(59^{\circ} \mathrm{N}, 5^{\circ} 20^{\prime} \mathrm{E}\right)$.

Diagnosis: Shell: Pyrgiscus with fairly elongate, slightly 
cyrtoconoid shell. Total shell length not exceeding $9 \mathrm{~mm}$. Number of whorls 14 or less. Shell, reddish or fulvous, rarely with coloured band around the periphery, nearly opaque. Sculpture c. 20 slightly opisthocline axial ribs, with wide interspaces. Four to six incised spiral lirae in the interspaces. Whorls evenly rounded, almost flat. Columellar fold visible as a slight thickening of the columella. Protoconch, large for genus, planorboid, only slightly inclined. Soft parts: "Body of a clear pale-azure colour, irregularly aspersed with snow-white flakes; snout (= mentum) extending from the conjoined tentacular membrane to a little beyond the foot, and forming a sort of head-veil; it is long flat and bilobed: tentacles short, broad, very little folded, and diverging; tips rounded: eyes placed on the inner bases of the tentacles: foot large, moderately long, auricled in front, tapering behind to a point when at full stretch, but rounded when at rest." From Jeffreys (1867), citing Clark (1855). Operculum: Not known.

Biology: Not known. Cabioch (1968) reports Turbonilla crenata as common in fine sediments, $18 \mathrm{~m}$, near Roscoff in the French part of the British Channel. Whether this refers to P. rufus s.s. or P. fulvocinctus is hard to say due to the various interpretation of $T$. crenata (see below).

Distribution: Never previously reported from Norway. In my material a single specimen, $4.4 \mathrm{~mm}$ long from a station in Ryfylke (15 m, soft bottom, 27/8 2007, coll. P. J. Johannessen) and two old and worn shells from Grimstad, Aust-Agder. Outside Norway reported with a query from the Swedish west coast (Schander pers. commn., and Warén in Hansson 1998). The distributional limits are impossible to ascertain because of the confusion with P. fulvocinctus. However, it is reported from the North Sea coast of Scotland by McKay \& Smith (1979) (as dead shells). Found chiefly in Devonshire (Clark); Dorsetshire (Hanley); and the S.W. coast of England, in not very deep water (Forbes \& Hanley 1850-51:276). According to Jeffreys (1867), who regards it as the southern one of two varieties, it has an extensive range southwards from the southern and southwestern coasts of the British Isles, along the Atlantic coasts of France, Spain, Portugal, Madeira and the Canary Isles, and also throughout the Mediterranean and Adriatic. The southern distribution is confirmed by more recent reviews (Peñas et al. 1996, Peñas \& Rolán 1997, Cachia et al. 2001, Öztürk \& Bakir 2013)

Remarks: By some authors, (e.g. Smith \& Heppell 1991) regarded as a synonym of $T$. crenata, or by most (following van Aartsen 1981) as conspecific with T. fulvocinctus, but in my opinion a separate species. Van Aartsen (1981:75) states: "Turbonilla rufa (Philippi, 1836). Several forms have been described with essentially the same type of spiral sculpture consisting of spirally incised lines. The difference between these forms viz. more or less slender, uniformly coloured or banded and more or less axial ribs, in my opinion are not enough to warrant different species. I therefore regard fulvocincta (Thompson), crenata (Brown), fasciata (Req.), spectabilis (Mtrs.), and exigua (Mtrs.) all to be varieties of one and the same species: Turbonilla rufa (Philippi, 1836)." Several early British malacologists are of another opinion, as is clear from a quotation from Forbes \& Hanley (1853:276): "An acquaintance with the specimens of both these shells $(C$. rufa and C. fulvocincta) enables us at length to declare their specific distinctness; on this one point we can accord with the views expressed by Mr. Clark in one of his many papers on the Chemnitzia." McKay \& Smith (1979) record this species from the northern North Sea and the east coast of Scotland. Further down on the page they discuss Turbonilla interrupta (Totten, 1835) [ = T. fulvocincta], for which they state: "Found alive at a number of stations 1922-1924 (Marine Laboratory). There are several $19^{\text {th }}$ century records and it was obtained dead off Rosehearty in 1977. Many early records may be in error for Turbonilla crenata". Fretter et al. (1986) regard fulvocincta as a variety of crenata, but still think there is room for doubt (note, p. 644): "The distinction between crenata and fulvocincta is not always clear - and not always made by systematists - but crenata tends to have fewer costae per whorl than fulvocincta, to have less oblique sutures, and a less regular pattern of colour bands". The different conclusions add up to a rather confusing picture. Either $P$. fulvocinctus and $P$. crenatus are both synonyms of $P$. rufus, or $P$. fulvocinctus is a different species from $P$. crenatus which again is a synonym of $P$. rufus or the other way around. I provisionally agree with Forbes \& Hanley (1853) that $P$. fulvocinctus and $P$. rufus are two different species. I accept the arguments of Smith \& Heppell (1991) concerning the availability of the names of Brown (1827) for Pyramis crenatus (as well as Eulimella laevis). However the confusion regarding which species Brown's $P$. crenatus refers to (is it a synonym of $P$. fulvocinctus, or of $P$. rufus? Both have been suggested, and no types are known) makes it problematic to accept $P$. crenatus as name for this species. P. rufus was described from a shell from Sicily. Neither $P$. fulvocinctus nor $P$. crenatus are mentioned in the literature from the Mediterranean.

\section{Pyrgiscus fulvocinctus (Thompson, 1840)} Figures 109-110

\section{Turritella fulvocincta Thompson, 1840:98}

Chemnitzia fulvocincta (Thompson) - Alder 1848; Forbes \& Hanley 1853; Clark 1855

Pyrgulina (Pyrgostelis) fulvocincta (Thompson) - Monterosato 1884

Turbonilla (Pyrgostelis) fulvocincta (Thompson) - Kobelt 1903 Turbonilla (Pyrgisculus) fulvocincta (Thompson) - Winckworth 1932

Pyramis crenatus Brown, 1827:14

Turbonilla crenata (Brown) - Cabioch 1968; Rodriguez Babio \& Thiriot-Quièvreux 1975; McKay \& Smith 1979; Fretter et al. 1986; Graham 1988; Smith \& Heppell 1991; Høisæter 2009; CLEMAM 2014

Turbonilla (Pyrgiscus) crenata (Brown) - Høisæter 1986; Smith 


\section{\& Heppell 1991}

Pyrgiscus crenatus (Brown) - Schander et al. 2003

Turbonilla rufa (Philippi) - Lovén 1846a, b; Asbjørnsen 1854;

G.O. Sars 1878; Appellöf 1897; Grieg 1897, 1898, 1914,

1915; van Aartsen 1981; Öztürk \& Bakir 2013

Turbonilla (Pyrgiscus) rufa (Philippi) - Dautzenberg \& Fischer 1925

Chemnitzia rufa (Philippi) - Forbes \& Hanley 1850-51; Collin 1880, 1884; Petersen 1888

Odostomia rufa (Philippi) - Jeffreys 1848; M. Sars 1870

Pyrgiscus rufus (Philippi) - Ankel 1936; Thorson 1946

Chemnitzia rufa var. fulvocincta (Thompson) - Norman 1879

Odostomia rufa var. fulvocincta (Thompson) - Jeffreys 1867,

1870; Friele 1874; Jeffreys 1884; Marshall 1900

Turbonilla interrupta (Totten) - McKay \& Smith 1979

Turbonilla (Pyrgiscus) interrupta (Totten) - Nordsieck 1972;

Høisæter 1986

Type material: Not known.

Type locality: Presumably Ireland.

Material seen: Norway - North Sea shelf, 9 spms; Skagerrak, 11 spms, 11 shs; Hordaland, 2 spms, 18 shs; Sogn og Fjordane, 4 shs (ZMBN 1042, 4874); Møre og Romsdal, 3 spms, 4 shs; Nord-Trøndelag, 1 sh; Nordland, 2 spms, 2 shs.

Diagnosis: Shell: Pyrgiscus with elongate, slender, only slightly cyrtoconoid shell. Total shell length not exceeding 11 $\mathrm{mm}$. Number of whorls 12 or less. Shell cream coloured with one or two rufous to tawny bands around periphery, semisolid, semitransparent. Sculpture consisting of 14-18 orthocline ribs, narrower than the interspaces, and six to nine spiral grooves in the interspaces. Whorls evenly rounded, only slightly convex. Protoconch planorboid, only slightly inclined and larger than the other Norwegian species (diameter: 347-389 $\mu$ m, mean 367 $\mu \mathrm{m})$. Soft parts: "Body whitish: snout (= mentum) long and bilobed: tentacles leaf-like, rather short and broad, set well apart: eyes small sessile on the inner bases of the tentacles: foot squarish in front, with small angular corners, and pointed behind." As quoted from Jeffreys (1867) citing Forbes \& Hanley (1853). Operculum: Pictured by G.O. Sars (1878).

Biology: Little is known about the biology of this species. It is found on muddy sand bottom at intermediate depths, from ca. $30 \mathrm{~m}$ down to at least $150 \mathrm{~m}$. Sometimes found together with Turritella.

Distribution: In Norway reported by G.O. Sars (1878) from Lofoten, but only from a single $8.5 \mathrm{~mm}$ long specimen. Also recorded from Trondheimsfjorden, from a single specimen (Norman 1893). Friele (1874) and Norman (1879) both report it from the Bergen area, Friele states it to be rather common in the area. G.O. Sars also has records from western and southern Norway. In my material, ten specimens from Skagerrak, 14 specimens (of which eight from the North Sea) and an additional 22 shells from the Espegrend area north to Vevelstadsundet $\left(65^{\circ} 42^{\prime} \mathrm{N}, 65-42 \mathrm{~m}\right.$, sand and shell gravel) and south west of Bodø $\left(67^{\circ} 16^{\prime} \mathrm{N}, 13 \mathrm{~m}\right.$, coarse shell gravel and Laminaria, empty shell). It seems to be most common along the shallow sandy outer fjord bottoms in Møre og Romsdal in Norway. Outside Norway, because of the uncertainty as to the specific distinctness of this species, the southern limits of its distribution are uncertain. It is reported, together with P. rufus, from the eastern coast of Scotland (McKay \& Smith 1979), and also from other North Sea localities. In Scandinavian waters (outside Norway) from Øresund through Kattegatt and Skagerrak (Petersen 1888). A species called Turbonilla rufa, but from the excellent photographs seem to be indistinguishable from $P$. fulvocincta, is reported to be the commonest 'Turbonilla' species along the Turkish coasts (Öztürk \& Bakir 2013).

Remarks: As is explained in the Remarks for P. rufus above, I think it most likely that this is a species distinct from $P$. rufus. The few shells of $P$. rufus I have seen, and the clear statements from Clark (1855), and Forbes \& Hanley (1853) support this. The question can only be settled, however, by studying the living specimens and the biology of both forms, or by means of DNA. Although P. fulvocinctus is most variable as regards both the height/width ratio and the development of the coloured band, I consider the extreme forms with more or less uniform brown periostracum and widest shell shape as representatives of $P$. rufus. The remaining forms are thus all forms of the common Norwegian species $P$. fulvocinctus. Schander et al. (2003) included specimens of both Pyrgiscus crenatus ( $=$ P. fulvocinctus) and $P$. rufus in their $16 \mathrm{~S}$ analysis, both from more or less the same locality on the Swedish west coast. They found the two to agree $100 \%$ among the 200 characters unambiguously aligned, although scrutiny of their raw data reveals that there are seven differences (four of them indels) among the 483 characters they had sequenced. Whether the two specimens studied were two extremes of what I have called P. fulvocinctus above, or really one of each species is hard to tell. Jeffreys (1884) claimed that this species is identical to the American P. interruptus (Totten). Van Aartsen (1981) disagreed with Jeffreys, and regarded $P$. interruptus as an exotic species, not closely related to the European ones in the P. rufus-complex. P. fulvocinctus is a large and conspicuous species, and in spite of being not particularly abundant, it is one of the more frequently occurring species in Norwegian fauna lists.

\section{Pyrgiscus jeffreysii (Forbes \& Hanley, 1850-51)}

Chemnitzia Jeffreysii Forbes \& Hanley, 1850-51:251 (in synonymy)

Turbonilla jeffreysii (Forbes \& Hanley) - Fretter et al. 1986; Graham 1988

Turbonilla jeffreysii (Jeffreys, 1848) - Peñas et al. 1996; Öztürk \& Bakir 2013

Turbonilla (Pyrgisculus) jeffreysii (Forbes \& Hanley) Winckworth 1932

Turbonilla (Dunkeria) jeffreysii (Jeffreys) - Smith \& Heppell 
1991

Melania scalaris Philippi, 1836:157 (not Melania scalaris Wagner in Spix, 1827, nor Melania scalaris Sowerby, 1829) Chemnitzia scalaris (Philippi) - Forbes \& Hanley 1850-51; Clark 1855; Jeffreys, 1859

Odostomia scalaris (Philippi) - Jeffreys 1848, 1867; Jeffreys 1884; Marshall 1900

Pyrgulina (Pyrgisculus) scalaris (Philippi) - Monterosato 1884 Parthenina (Pyrgostelis) scalaris (Philippi) - Kobelt 1903

Pyrgiscus scalaris (Philippi) - Ankel 1936

Turbonilla scalaris (Philippi) - van Aartsen 1981; Rolán Mosquera 1983

Turbonilla (Pyrgisculus) scalaris (Philippi) - Iredale 1915

Turbonilla (Dunkeria) scalaris (Philippi) - Nordsieck 1972

Type material: Not known (see van Aartsen 1981).

Type locality: Exmouth??

Material seen: None.

Diagnosis: Shell: Pyrgiscus with somewhat compressed, cyrtoconoid shell. Apical angle about $25^{\circ}$ to $30^{\circ}$. Total shell length not exceeding $6 \mathrm{~mm}$. Number of whorls 8 or less. Spire pointed, with distinctly shouldered, sometimes angulated whorls. Colour cream, with 2-3 brownish bands encircling the last whorl, disappearing on dead shells. Sculpture straight, lamellar, axial ribs with numerous spiral elevations in the intervals. Aperture rhomboid, no visible columellar fold Protoconch probably at an angle of about $90^{\circ}$ to the teleoconch, but perhaps somewhat immersed in the teleoconch as well. (From Jeffreys 1867, Kobelt 1903, van Aartsen 1981, and Fretter et al. 1986). Soft parts: Not known. Operculum: Not known.

Biology: This species has been reported from moderately shallow depths, 3-50 fathoms, from muddy gravel in association with hydroids, especially species of Halecium. According to Fretter et al. (1986) "Food. The hydroids with which they occur, perhaps mainly species of Halecium, Hydrallmannia and Antennularia since their nematocysts occur in the faeces."

Distribution: No reliable records from Norway. It is a southern species never positively identified as Recent in north European waters. The only statement to the contrary stems from Jeffreys (1884), who cites McAndrew as source for a record from Norway. In the same place Jeffreys reports the species from Unst in Shetland. Both records need verification as they are in opposition to all other available records, which indicate a lusitanian range, from the Adriatic and Aegean in the Mediterranean and Madeira in the Atlantic, to St. George's Channel between Wales and Ireland and to a line between Torquay and Cherbourg in the English Channel (Jeffreys 1867; 1884; Marshall 1900; Kobelt 1903). Not mentioned by McKay \& Smith (1979), and thus not likely to be found on the North Sea coast of Scotland. According to Fretter et al. (1986) "From the Mediterranean north to southern Scandinavia and the west coast of Sweden. Not in most of the North Sea nor in the Channel and Irish Sea". According to Warén (in Hansson 1998), probably not part of the Scandinavian fauna.
Remarks: The nomenclature of this name is somewhat convoluted. It is usually attributed to Forbes \& Hanley (185051), who introduced it in the comments to Chemnitzia scalaris Philippi "Among collectors this shell has generally been distinguished by the manuscript name Jeffreysii...". A similar and earlier, informal introduction is however due to Jeffreys (1848) after listing a number of synonyms for Odostomia scalaris (Philippi) "Var. a. testacei coloris; costae admodum pauciores. Exmouth (Mr. Clark, who gave to this variety the MS name of Jeffreysii)."

\section{Pyrgiscus rufescens (Forbes, 1846) Figures 111-113.}

Chemnitzia rufescens Forbes, 1846:66

Chemnitzia scalaris (Philippi) (in part) - Clark 1855; Jeffreys 1859; Petersen 1888

Turbonilla scalaris (Philippi) - G.O. Sars 1878

Pyrgiscus scalaris (Philippi) (in part) - Ankel 1936

Odostomia scalaris (Philippi) (in part) - Jeffreys 1848

Odostomia scalaris var. rufescens (Forbes) - Jeffreys 1867, 1870; Friele 1874; Jeffreys 1884; Marshall 1900

Pyrgulina (Pyrgisculus) scalaris var. rufescens (Forbes) Monterosato 1884

Turbonilla (Dunkeria) scalaris forma rufescens (Forbes) Nordsieck 1972

Chemnitzia rufescens Forbes - Jeffreys 1847; Forbes \& Hanley 1850-51; McAndrew \& Barrett 1856; Norman 1879

Parthenina (Pyrgostelis) rufescens (Forbes) - Kobelt 1903

Turbonilla (Pyrgisculus) rufescens (Forbes) - Winckworth 1932 Turbonilla rufescens (Forbes) - McKay \& Smith 1979; van Aartsen 1981; Fretter et al. 1986; Graham 1988; Høisæter 2009

Turbonilla (Pyrgiscus) rufescens (Forbes) - Høisæter 1986

Turbonilla (Dunkeria) rufescens (Forbes) - Smith \& Heppell 1991

Turbonilla interrupta (Totten) - Lovén 1846a, b; Asbjørnsen 1854 (not Turritella interrupta Totten, 1835)

Type material: Not known.

Type locality: Arran or Oban, western Scotland.

Material seen: Norway - Skagerrak, 32 spms, at least 7 shs; Hordaland, 12 spms, at least 4 shs; Møre og Romsdal, 1 spm, 8 shs; Nord-Trøndelag, 1 spm, 6 shs; Nordland, 5 spms, at least 9 shs.

Diagnosis: Shell: Pyrgiscus with distinctly cyrtoconoid shell, apical angle $16^{\circ}$ or more. Total shell length not exceeding $8.5 \mathrm{~mm}$. Number of whorls 9 or less. Shell semisolid, tawny, semitransparent, with three spiral bands of orange brown as in jeffreysii, but these are darker and all are of more regular occurrence. Lower part of the fairly convex whorls more flattened than the upper part. Shell sculpture slightly prosocline, equidistant axial ribs with numerous spiral grooves 
in the interspaces. No columellar fold. Prominent heterostrophic protoconch of $13 / 4$ whorls, its diameter less than $340 \mu \mathrm{m}$ and its axis length less than $290 \mu \mathrm{m}$, with nucleus inclined to, but not immersed in the teleoconch. Soft parts: Described by Forbes \& Hanley (1850-51): "The specimen is white, slightly tinged with brown. The tentacula are rather long, lanceolate, set well apart, and bearing the eyes nearly centrally at their bases. The mentum is rather narrow and bilobed: the foot is oblong-lanceolate, obtusely angled in front, triangular behind." I have made a sketch of a specimen from Raunefjorden, $\mathrm{W}$ of Fleslandskj., 80-60 m (Figure 112, bottom). The pigmented mantle organ is long (about ten times as long as broad) and bright yellow in colour. Mentum broad and squarely cut in front, bilobed. Operculum: No 'tooth'-shaped internal process, at most a narrow, spiral ridge. It is thin and semitransparent of a dark yellowish horncolour, drawn out into a tip at the lower end, and evenly cut at the similarly narrowed upper end. Spire small and terminal at the upper corner (Figure 112).

Biology: Not known. Dredged from ca. 20 to $150 \mathrm{~m}$, but most common from ca. 50 to around $100 \mathrm{~m}$ on rather coarse shell gravel bottoms.

Distribution: In Norway P. rufescens is reported from Oslofjorden (Jeffreys 1870), north to at least $67^{\circ} 15^{\prime} \mathrm{N}$. There are a few, scattered records in the old literature. G.O. Sars (1878) reports it from his three southern regions ('Ora occident., 'Ora meridion.', and 'Sinus Christianensis') but with no further information. Friele (1874) reports it as rare from two localities just north of Bergen, while Norman (1879) mentions two localities in Korsfjorden and Raunefjorden. In my material 21 specimens and one shell from Skagerrak, 16 specimens and 36 shells from the Espegrend area north to Fugløyfjord $\left(67^{\circ} 01^{\prime} \mathrm{N}, 70-50 \mathrm{~m}\right.$, stones and shells of Modiolula phaseolina), and empty shells to $67^{\circ} 15^{\prime} \mathrm{N}$. Outside Norway it is reported by Lovén (1846a) from Bohuslän, while Petersen (1888) reported a single empty shell from Kattegatt. There are a few records from British and Irish localities, the most recent ones from north-western areas (Fretter et al. 1986). On the eastern coast of Scotland it seems to be represented by dead shells only (McKay $\&$ Smith 1979). I have not been able to find any verified records from south of the Irish coast.

Remarks: Concerning the specific distinctness from $P$. jeffreysii (Forbes), opinions are divided. Forbes \& Hanley (1850-51) express no doubts as to the specific distinctness of the two forms, while Clark $(1855: 411,439)$ regarded them as two varieties of the same species. This latter conclusion was based on studies of living specimens of what he regarded as the two forms, taken at the same locality. Forbes \& Hanley (1853:276) in an appendix to their work did not agree. Jeffreys (1867) and, following him, most later authors adopted the view of Clark, mainly because Clark had found a specimen with the upper whorls like $P$. jeffreysii, and the lower whorls like $P$. rufescens. However Monterosato (1884, 1889), Tryon (1886), Kobelt (1903), and later Winckworth (1932) all disagreed with Jeffreys, and readopted the view of Forbes \& Hanley (1850-51), that this is a distinct species. If the illustrations in van Aartsen (1981) and Rolan Mosquero (1983) are representative, the south European P. jeffreysii is very distinct, with its Epitonium-like lamellae. Van Aartsen also seems to accept the specific distinctness of $P$. rufescens without question, although Nordsieck (1972), had again subjugated it as a form of $P$. jeffreysii. According to Fretter et al. (1986), P. jeffreysii is clearly separable from rufescens, having a much more turreted profile to the spire, a relatively broader shell, and more costae per whorl. They do not specifically mention the lamellae-like costae (ribs), which probably is the most reliable character. However, as shown above, the Norwegian forms of $P$. rufescens are very variable (compare Figure 111 with Figure 113), and both of the drawings presented by Fretter et al. (1986), the one presented as $P$. rufescens and the one called $P$. jeffreysii are certainly only two growth varieties of $P$. rufescens, as was obviously also the opinion of Thorson, who originally gave names to these drawings by Winther. I agree with most recent authors that $P$. rufescens is specifically different from $P$. jeffreysii, the last not recorded from Norwegian waters.

\section{Incertae Sedis}

\section{Bacteridium Thiele, 1929}

Type species, by original designation: Eulimella praeclara Thiele, 1925

\section{Bacteridium cf. carinatum (de Folin, 1870) Figure 114}

\section{Eulimella carinata de Folin, 1870:209}

Eulimella carinata de Folin - Schander 1994; van Aartsen 1994. Bacteridium carinatum (de Folin) - Warén 1995; Peñas et al. 1996; Bogi \& Galil 1997; Peñas \& Rolan 2001 Anisocycla cf. carinata (de Folin) - van Aartsen et al. 2000

Type material: Two syntypes in MNHN (van Aartsen et al. 2000).

Type locality: Cagnabac, Senegal (Peñas \& Rolan 2001).

Material seen: Norway - Hordaland, 3 spms (Fensfjorden).

Diagnosis: Shell: Thin, loosely coiled, whorls shouldered, shiny surface with only microscopical striation, no visible columellar fold, protoconch (presumably) planorboid, upturned and almost disjoint, and easily broken.

Soft parts: Lacking eyes. Operculum: Not known.

Biology: Not known.

Distribution: First record from Norway, and never before reported from Atlantic waters north of Gibraltar.

Remarks: Three samples from the inner, deeper parts of Fensfjorden $(580 \mathrm{~m}$ and $690 \mathrm{~m})$ contained a few tiny (all less than two $\mathrm{mm}$, and $0.6-0.7 \mathrm{~mm}$ wide) pyramidelloid shells. 

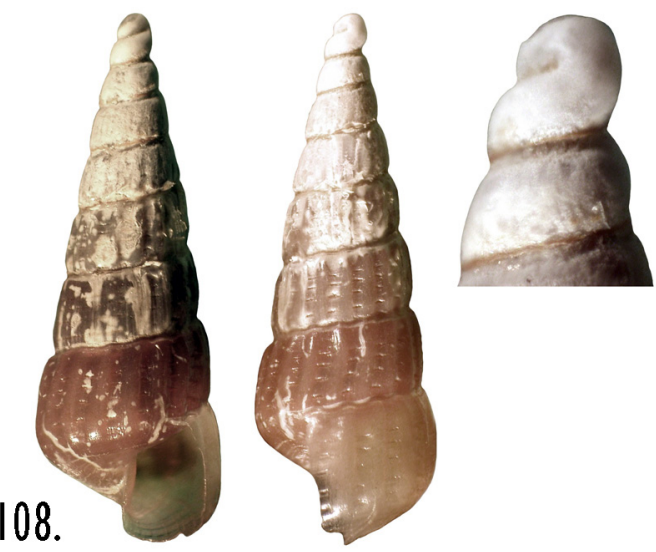

110.
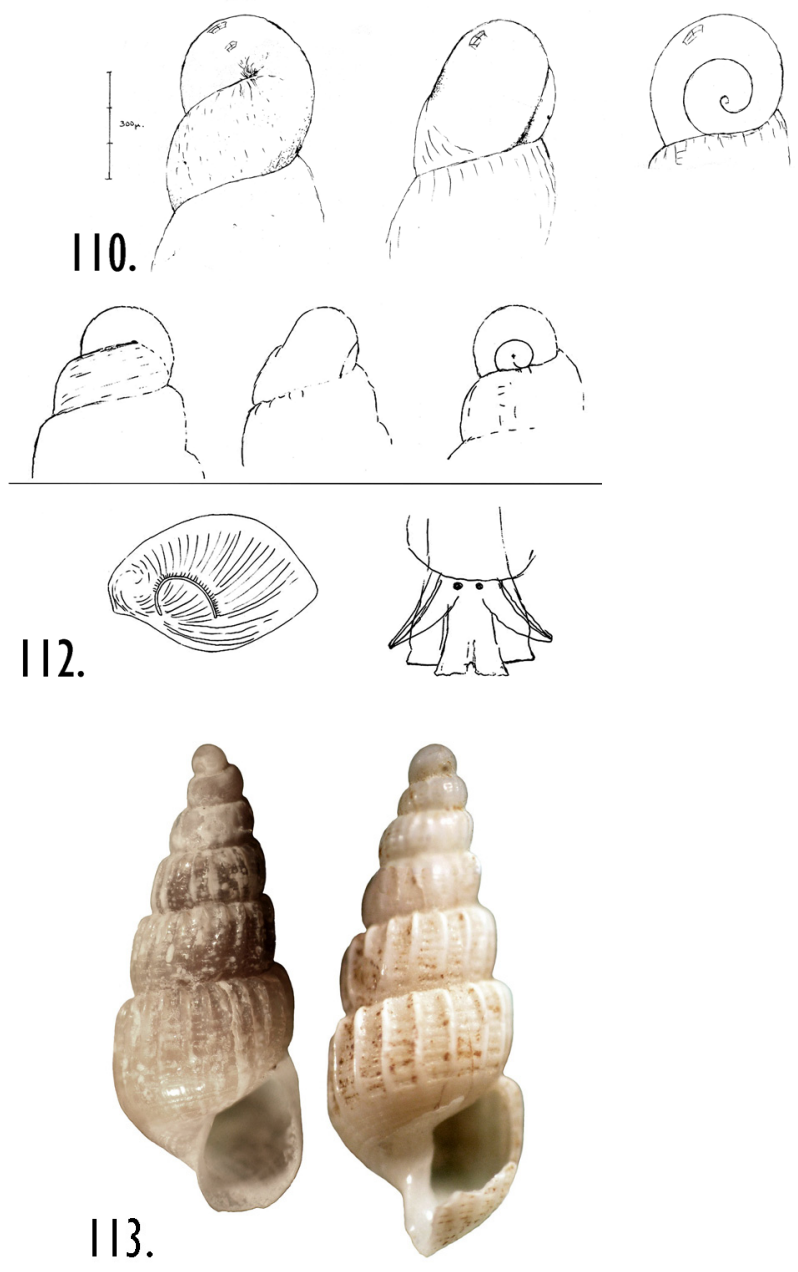

Figure 108. Pyrgiscus rufus. A specimen from Lysefjorden, $59^{\circ} \mathrm{N}, 5^{\circ} 20^{\prime} \mathrm{E}, 15 \mathrm{~m}, 4.4 \mathrm{~mm}(\operatorname{Ref} 8,27 / 07)$.

Figure 109. Pyrgiscus fulvocinctus. Ellingsøyfjorden, Møre og Romsdal, 62²8.7’'N, 06'19’E 52-44 m, $7.75 \mathrm{~mm}$ (T 70056).

Figure II0. Pyrgiscus fulvocinctus. Three orientations of protoconch.

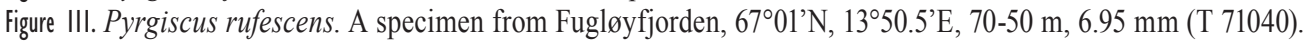

Figure II2. Pyrgiscus rufescens. Protoconch, operculum, head/foot complex.

Figure II3. Pyrgiscus rufescens. Two shells illustrating the variability of the species. A shell from Torungen, Hisøy, (Aust-Agder) 58 $24^{\prime} \mathrm{N}$,

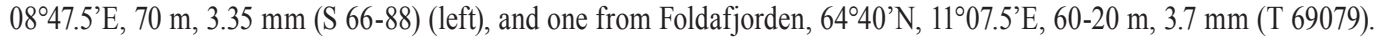

Figure II4. Bacteridium cf. carinatum. A specimen from Fensfjorden, $60^{\circ} 45.5^{\prime} \mathrm{N}, 05^{\circ} 14.7^{\prime} \mathrm{E}, 690 \mathrm{~m}, 1.9 \mathrm{~mm}$ without protoconch (E 251A-72)

(left), one from Benidorm, Alicante, Spain (1.8 mm), from Peñas et al. (1996), and one from SE of Boa Vista, Cape Verde (1.4 mm)

(SEM), from van Aartsen et al. (2000). 
Three of them were live caught, and they were without eyes. Unfortunately all had lost their protoconchs, making any attempts at identification provisional. Bacteridium carinatum (de Folin, 1870), a species reported from the western Mediterranean (Peñas et al. 1996) is strikingly similar to my specimens, both in the channeled suture, somewhat flattened whorls and a certain sturdyness and shape of the aperture. Bacteridium carinatum was described from Senegal and has so far not been found north of the Mediterranean coast of Spain, otherwise it lives in West Africa (south to Angola), and it has also been recorded from the Mediterranean coast of Israel (Bogi \& Galil 1997). This taxon is briefly discussed in van Aartsen (1994) and van Aartsen et al. (2000), and in Peñas \& Rolán (2001). While van Aartsen et al. regard Bacteridium as an unnecessary name for striated species of the genus Anisocycla, Peñas \& Rolán follow Schander (1994) and Warén (1995) in retaining Bacteridium as a close relative of Eulimella. In Figure 114 I show one of my specimens together with a specimen from Alicante, western Mediterranean, and one from Cape Verde. The illustrations I have seen of specimens from Spain and Sahara (Peñas \& Rolán 2001) are wider than the Cape Verde specimen, and I am not convinced that they are congeneric. In any case I follow Warén (1995) in keeping B. carinatum in the Pyramidellidae, as opposed to Ebala (or Anisocycla) nitidissima which is a member of Murchisonellidae. Recent molecular work indicates that the Murchisonellidae is only distantly related to the Pyramidellidae (see Introduction above, and Dinapoli \& Klussmann-Kolb 2010). The name Bacteridium (based on Eulimella praeclara Thiele, 1925) for this species has to my knowledge not been properly justified in the literature. The closest is this citation from Schander (1994): 'I consider Eulimella carinata De Folin, 1870 from West Africa as belonging to the Bacteridium group'.

\section{DISCUSSION}

To my knowledge, this review is based on the most extensive material of pyramidellids from a single biogeographic region anywhere. However, the geographical distribution of the material is still too uneven and spread over a too long time period for a sound comparison between different parts of the region, or the distribution with depth, habitat or biogeography to be made. Some tentative conclusions are possible though. First of all, a very high degree of variability was found for some of the taxa, especially in Nordland county. Whether this is due to high intraspecific variability, or to a number of unsuspected species complexes, is impossible to say without supplementary investigations, preferably by means of DNA. This is the main reason for the 'cf'-species included. Some species were represented by only a few specimens, and the possibility that they are only the extremes of a continuous cline within a species cannot be excluded. Eulimella ataktos is one example, as its distinctness from $E$. ventricosa is based on relative $\mathrm{W} / \mathrm{H}$ ratios only.
The assignment of any pyramidellid genus to subfamily is supposed to be a straightforward procedure, those with short, few-whorled shells belong to the Odostomiinae, while those with elongated many-whorled shells are members of Turbonillinae. This subdivision is not based on solid phylogenetic analyses however, and more recent work indicates that some groups should be reassigned. Thus Wise (1996), in a morphological cladistic analysis based on material from North America, and three Indo-Pacific species, concludes that the traditional subfamily subdivision is insufficient. He introduced a new subfamily he named Sayellinae. Schander et al. (1999b) reanalysed this data-set and included three further species traditionally included in Odostomiinae. They arrived at the conclusion that except for the four species included by Wise in Odostomiinae and the three in Pyramidellinae, the data did not permit any further phylogenetic conclusions. They specifically denied the reality of a subfamily Sayellinae. The material for both the analyses lacked the type of Odostomia, or any close relative of this species, a deficit curiously not commented on in any of the articles. Schander et al. (2003) introduced DNAdata to the phylogenetics of the Pyramidellidae. The data was not very extensive (32 species), and the molecular marker consisted of only a 483 character fragment of the mitochondrial $16 \mathrm{~S}$ gene. Nevertheless the results indicate that the traditional subfamilial subdivision should be modified, in that Pyrgiscus and Turbonilla apparently belong in different subfamilies, and that Ondina may be closer related to the Pyramidellinae than to the Odostomiinae.

My material stresses the importance of including the type species (or close relatives) in the analyses if names are given to a particular taxon. Thus the genus name Odostomia, and thus the subfamily Odostomiinae have been misused repeatedly over the years. The genus is probably endemic to northern Europe (and northwest Pacific?), and several of the specific characters, like the missing tentacular pads (specifically claimed to be present by Wise 1996 and Schander et al. 1999b), the peculiar attachment 'anchors' of the operculae, the $90^{\circ}$ protoconch angle, and the shovellike, unnotched mentum keeps them apart from the many other taxa called Odostomia in various parts of the world. The assimilated evidence supports the conclusion that the Odostomiinae as used above should rather be divided into a subfamily Chrysallidinae, and one Odostomiinae. Thus the definition of Odostomiinae in Schander et al. (1999b) should be transferred to Chrysallidinae, as the two species of 'Odostomia' included in the cladistic analyses are really more closely related to Chrysallida than to Odostomia s.s.

The observation of crawling animals of several of the taxa strongly suggests that classification based on shell features alone is perilous. 'Brachystomia' lukisi is certainly neither an Odostomia nor a member of Brachystomia s.s. The lack of tentacular pads and the presence of a strong columellar tooth indicate a placement in the Odostomiinae, although the close-set eyes, the peculiar bifurcate mentum, the very small larval shell and flat apex, and the thick, chalky shell 
indicate otherwise. 'Odostomia' conoidea is another deviating member of the Odostomia s.l. group, with a very characteristic bifid mentum. The DNA analysis of Schander et al. (2003) also indicate an isolated position of this taxon (together with $O$. corimbensis, since synonymized with $O$. conoidea by van Aartsen et al. 1998). They follow van Aartsen (1987) in assigning these two species to Megastomia, with $O$. conspicua as type species, as these species are supposed to share the character of toothlike spiral ridges inside the outer lip. When comparing specimens of the two species, I find very little similarity between the shells, the spiral ridges inside the outer lip are only present in some of the specimens, and therefore I find the assignment of $O$. conoidea to the 'genus' Megastomia to be suspicious. That $O$. conoidea (and thus $O$. corimbensis) should be excluded from Odostomia s.s. is not controversial however. Another of the conclusions of Schander et al. (2003) is that Pyrgiscus spp. should be removed from the vicinity of Turbonilla, and thus removed from the Turbonillinae. This I find very likely, and also the removement of Houbricka Wise, 1996 from the Turbonillinae. I consider Houbricka a synonym of Pyrgiscus. The morphology of the head/foot complex also supports the suggestion that Ondina spp. should be removed from the Odostomiinae.

This study supports the view that Pyramidellidae are primarily found in tropical and temperate waters. While 49 'species' are recorded as boreal in this summary, only one species, Liostomia eburnea (and possibly Aartsenia candida), is recorded in Norway solely from the Arctic waters in extreme north-eastern Norway. Two (or three) additional species are known from the Arctic proper (here defined as the Arctic Basin, Greenland and Spitzbergen), two species of Menestho (not inluded in this study), and Aartsenia candida (Odhner 1915, Kantor \& Sysoev 2006, Rosenberg 2009). A single species (Chrysallida sublustris) is found in the Norwegian Sea deep water basin and on the continental slope off Norway, in waters of constant negative temperature (but not in the Arctic) (Høisæter 2010). The remaining 49 'species' might all be classified as boreal, although they are not equally distributed along the whole Norwegian coast. Four of the common 'boreal' species, are reported by G.O. Sars (1878) from East Finnmark while one, Odostomia turrita, is recorded from the Russian part of the Barents Sea (Nekhaev 2011). All the remaining 'species' have their northern distributional limits somewhere in western Finnmark or further south.

Some species have so far only been found on the stretch between Rørvik $\left(65^{\circ} \mathrm{N}\right)$ and Hasvik $\left(70^{\circ} \mathrm{N}\right)$. Odostomia turgida, Ondina coarctata and Ondina divisa forma nobilis are only known from this part of the (outer) coast. Chrysallida bjoernssoni, C. hoeisaeteri and Rissopsetia cf. islandica are three species found (by me) in Norway only on the shelf or upper slope in Bleiksdjupet, off Andfjorden $\left(69^{\circ} 19^{\prime} \mathrm{N}\right)$. As these three species are only recently discovered and described, there is a possibility that more species might be discovered from the upper slope, above the layer of negative temperature water.
Another part of the coast with a number of 'endemic' species is the Skagerrak region. Their exact northwestern distributional limits are impossible to ascertain as the amount of collecting in the stretch from Egersund $\left(58^{\circ} 27^{\prime} \mathrm{N}\right)$ to Korsfjorden $\left(60^{\circ} 10^{\prime} \mathrm{N}\right)$ is sketchy to say the least. But the following five species have not been recorded north of $59.5^{\circ} \mathrm{N}$ : Parthenina wikanderi, Odostomia conspicua, Ondina warreni, Turbonilla pusilla and Pyrgiscus rufus. The latter is represented with a specimen from Lysefjorden $\left(59^{\circ} \mathrm{N}\right)$ the others have only been found in the Skagerrak area. Evidence also from other gastropod groups indicates that there is a biogeographic 'break' at around Egersund. Except for Parthenina wikanderi, all these species are probably northern extensions of populations having their main distribution further south in the North Sea or the English Channel. In contrast some species apparently have their main distribution in Norwegian waters: Chrysallida eximia, Eulimella compactilis, Pyrgiscus rufescens, and Ondina divisa are examples.

Whether any pyramidellids really show a preference for a certain section of the western (or northwestern) coast is hard to say. The limited material of the three (proper) species of Liostomia might be an example, as L. afzelii has its apparent centre of distribution (in Norway) on the Skagerrak coast, $L$. hansgei in the investigated part of Korsfjorden/ Fanafjorden (Hordaland), while L. clavula is most frequent on the coast of Møre og Romsdal. Jordaniella nivosa was only found on the outer coast near Korsfjorden, but might be an example of an opportunistic species visiting the Norwegian waters with infrequent intervals.

As to the distribution of the Norwegian species outside Norway, the available information is sparse. All the species from western and southern Norway have been reported also from the British Isles and further south along the Atlantic coasts of Europe. According to van Aartsen (1977, 1981, 1987, 1994) a majority of the species are also found in the Mediterranean, although often with slightly different shell morphologies. Two surveys of pyramidellids from the Turkish coast (Öztürk et al. 2013, Öztürk \& Bakir 2013) show that almost all the 'Norwegian' species of Odostomia, Brachystomia, Turbonilla (s.l.) and Eulimella known from the Atlantic coast of Spain are also found on the coast of Turkey, and with apparently the same range of variability as found in the Atlantic. A number of the 'Norwegian' species are apparently distributed also along the northern coasts of western Africa (Morocco and Mauretania) as well as in the Canary Isles (e.g. van Aartsen et al. 1998, 2000).

Mass congregations of pyramidellids are generally observed where potential host species are found in dense colonies, like banks of Mytilus (e.g. Fretter et al. 1986), or reefs of Pomatoceros, the dominating serpulid in shallow waters in Scandinavia (e.g. Ankel 1959). In the latter case, often three to five pyramidellid species coexist in large numbers on a single reef (Høisæter 1989). Also in other parts of the world serpulids creating 'reefs' are known to be substrate for sizeable populations of pyramidellids, either of a single 
species, or several species clustering together (Parthenina spp. and Odostomia hirotamurana, on Pomatoleios kraussi in Japan (Hori 2000); Fargoa spp. on Hydroides dianthus on the east coast of USA (Robertson \& Mau-Lastovicka 1979); Pseudoskenella depressa on Galeolaria caespitosa in southern Australia (Ponder 1973)). There is general acceptance for the idea that a specific pyramidellid species either feeds on sedentary polychaetes, or on mollusks (e.g. Robertson \& Mau-Lastovicka 1979) (A reported exception is the feeding on hydroids by Pyrgiscus jeffreysii, see Fretter \& Graham 1949). There also seems to be a taxonomic side to this host preference, as species feeding on mollusks in the same geographical region, is apparently closer related to each other than to any species feeding on polychaetes. Robertson (1978) has formalized this idea in allocating the species of small Odostomiinae from the east coast of USA feeding on polychaetes to the genus Fargoa, while those feeding on mollusks he put into the genus Boonea (of course based on several other characters than choice of host). My impression based on my Norwegian material does not contradict this hypothesis. Thus the pyramidellids consistently associated with Pomatoceros reefs either belong to Odostomia s.s., or to Spiralinella spiralis. Odostomia acuta found in close association with the sabellid polychaete Myxicola infundibulum strengthens this hypothesis. Another fact supporting this theory is the Japanese species Odostomia hirotamurana, (often caught on the serpulid Pomatoleios kraussi) which judging from a photograph in Hori (2000) is a typical Odostomia s.s., and according to Schander et al. (2003) sits in a clade with O. turrita. A number of species was found only occasionally together with Pomatoceros, and more consistently in samples with several potential mollusk host species, as $P$. interstincta, 'Brachystomia' lukisi and above all Brachystomia scalaris. The latter species appears, both from my observations and from the literature to be not very host specific. It has been reported from at least nine species of shallow water mollusks, both gastropods and bivalves. My studies indicate that still another host, Limaria hians is preferred when it occurs in high densities (no actual feeding observed however). B. scalaris might even be an exception to the rule that mollusk feeders do not associate with polychaetes, as in some samples containing no other potential host substrate than Pomatoceros, B. scalaris occurred in densities approaching those of $O$. turrita, an undisputed Pomatoceros feeder (see further Høisæter 1989).

Almost all the live caught specimens in this investigation were collected between 1965 and 1980. The distributions recorded at that time are undoubtedly not the same today. Several species are apparently opportunistic species, fluctuating in abundance from decennium to decennium. Of more serious concern is the fluctuating (or maybe declining) availability of suitable substrates. Attempts to resample the formerly most 'prolific' localities in the 1990ties and early years of the new millennium, have been disappointing, the extensive areas of live Pomatoceros 'reefs' have either disappeared or been covered by Laminaria saccharina lamina. As a result, my impression is that the pyramidellids have diminished appreciably in densities in recent years, although this might turn out to be an artefact to be corrected by further sampling.

\section{ACKNOWLEDGEMENTS}

I would like to thank all the individuals named above, who kindly left their material in my hands, and all those who assisted me in my diving activities during the sixties, especially Tor J. Samuelsen. The following people and institutions have been of particular help: Margit Jensen, Sigmund Bakke, Members of SUB, the diving club at the University of Bergen, Torleiv Brattegard, Per J. Johannessen, and last but not least, Per Bie Wikander. I am especially grateful to Ann-Helén Rønning and Karsten Sund from the Natural History Museum, University of Oslo, who took photographs of the type material of G.O. Sars. Jon Anders Kongsrud, University Museum of Bergen, and Arild Breistøl, Department of Biology, University of Bergen, helped me with the SEM-photos.

Photographs are taken by Arild Breistøl: Figure 5 (left), Figure 6, Figure 14, Figure 98 (right); Karsten Sund: Figure 71, Figure 76, Figure 77 (middle), Figure 98 (left); Egil Severin Erichsen: Figure 68, Figure 69. All other photographs (except those copied from published articles, as specified in the figure captions) taken and processed by the author.

Anders Warén, and an anonymous referee have gone through the ms with a fine comb and made it a much better product.

This regional review is dedicated to the memory of Christoffer Schander, whose work with pyramidellids is well known and highly appreciated world wide. He never got a chance to follow up his work with a revision of the Scandinavian pyramidellids, as he passed away in 2012, at the age of only 51 .

\section{REFERENCES}

Aartsen JJ van. 1977. European Pyramidellidae: I. Chrysallida. Conchiglie 13:49-64.

Aartsen JJ van. 1981. European Pyramidellidae: II. Turbonilla. Bollettino Malacologico 17:61-88.

Aartsen JJ van. 1984. The Pyramidellid-genera described by the marquis L. de Folin. Bollettino Malacologia 20:131-138.

Aartsen JJ van. 1987. European Pyramidellidae: III. Odostomia and Ondina. Bollettino Malacologico 23:1-34.

Aartsen JJ van. 1988. Nomenclatural notes. 6. The generic name Eulimella (Gastropoda, Opisthobranchia, Pyramidellidae). Basteria 52:171-174.

Aartsen JJ van. 1994. European Pyramidellidae: 4. The genera Eulimella, Anisocycla, Syrnola, Cingulina, Oscilla, and Careliopsis. Bollettino Malacologico 30:85-110.

Aartsen JJ van, Giannuzzi-Savelli R. 1991. New names for wellknown European marine Mollusca. Bollettino Malacologico 27:1-8. [Not seen].

Aartsen JJ van, Gittenberger E, Goud J. 1998. Pyramidellidae (Mollusca, Gastropoda, Heterobranchia) collected during the 
Dutch CANCAP and MAURITANIA expeditions in the southeastern part of the North Atlantic Ocean part 1. Zoologische Verhandelingen Leiden 321:1-57.

Aartsen JJ van, Gittenberger E, Goud J. 2000. Pyramidellidae (Mollusca, Gastropoda, Heterobranchia) collected during the Dutch CANCAP and MAURITANIA expeditions in the southeastern part of the North Atlantic Ocean part 2. Zoologische Mededelingen Leiden 74(1):1-50.

Aartsen JJ van, Menkhorst HP. 1996. Nordsieck's Pyramidellidae (Gastropoda Prosobranchia): A revision of his types. Part 1: The genera Chrysallida, Ondina s.n. Evalea. and Menestho. Basteria 60:45-56.

Aartsen JJ van, Menkhorst HP, Gittenberger E. 1984. The marine Mollusca of the Bay of Algeciras, Spain, with general notes on Mitrella, Marginellidae and Turridae. Basteria Supplem. 2:1-135.

Aartsen JJ van, Smith SM. 1996. Odostomia harveyi spec. nov. from the Northern Atlantic Ocean (Gastropoda, Pyramidellidae). Basteria 60:149-151.

Abbott RT. 1974. American Seashells. 2. edition. Van Nostrand Reinhold, New York. 663 p.

Adams CB. 1852. Catalogue of shells collected at Panama with notes on synonymy, station, and habitat. Annals of the Lyceumof Natural History, New York 5:222-549

Adams J. 1797. The specific characters of some minute shells discovered on the coast of Pembrokeshire, with an account of a new marine specimen. Transactions of the Linnean Society of London 3:64-69. [Not seen].

Alder J. 1844. Description of some new British species of Rissoa and Odostomia Annals and Magazine of Natural History 13:323328.

Alder J. 1848. A Catalogue of the Mollusca of Northumberland and Durham. Transactions of the Tyneside Naturalists' Field Club 12::97-209.

Alder J. 1850. Additons to the Mollusca of Northumberland and Durham. Transactions of the Tyneside Naturalists' Field Club 1:358-363.

Ankel F, Christensen AM. 1963. Non-specifity in host selection by Odostomia scalaris Macgillivray. Videnskabelige Meddelelser fra Dansk Naturhistorisk Forening i København 125:321-325.

Ankel WE. 1936. Prosobranchia. Tierwelt der Nord- und Ostsee $9 \mathrm{~b}: 1-240$.

Ankel WE. 1939. Beobachtungen an Prosobranchiern der schwedischen Westküste. Arkiv för Zoologi 30A:1-27.

Ankel WE. 1949a. Die Nahrungsaufnahme der Pyramidelliden. Zoologischer Anzeiger, Suppl. B 13:478-484.

Ankel WE. 1949b. Die Mundbewaffnung der Pyramidelliden. Archiv für Molluskenkunde 77:79-82.

Ankel WE. 1959. Beobachtungen an Pyramidelliden des GullmarFjordes. Zoologischer Anzeiger 162:1-21.

Appellöf A. 1896. Faunistiske undersøgelser i Herløfjorden. Bergens Museums Årbog 1894-95 (11):1-11.

Appellöf A. 1897. Faunistiske undersøgelser i Osterfjorden. Bergens Museums Aarbog 1896 (13):1-13.

Asbjørnsen PC. 1854. Bidrag til Christianiafjordens Litoralfauna. I. Mollusker. Nyt Magazin for Naturvidenskaberne 7:307-366.

Bartsch P. 1909. Pyramidellidae of New England and the adjacent region. Proceedings of the Boston Society of Natural History 34:67-113.

Bartsch P. 1955. The pyramidellid mollusks of the pliocene deposits of North St. Petersburg, Florida. Smithsonian Miscellaneous Collections 125(2):1-102.

Bogi C, Galil B. 1997. Discoveries along the Israeli coast. La
Conchiglia 284: 42-45

Bouchet P, Rocroi J-P. 2005. Classification and Nomenclator of Gastropod Families. Malacologia 47 (1-2):1-397.

Brocchi GB. 1814. Conchiologia fossile subapennina con osservazioni geologiche sugli Apennini e sul suolo adiacente. Vol. 2, pp. 241-712, 16 tables. Stamperia Reale, Milano.

Brøgger WC. 1872. Bidrag til Kristianiafjordens Molluskfauna. Johan Dahl, Christiania. 43 pp.

Brøgger WC. 1901. Om de senglaciale og postglaciale nivåforandringer $\mathrm{i}$ Kristianiafeltet Molluskfaunaen. Norges Geologiske Undersøgelse 31:1-731.

Bruyne RH de, Leeuwen S van, Gmelig Meyling A, Daan R. 2013. Schelpdieren van het Nederlandse Noordseegebied. Ecologische atlas van de mariene weekdieren (Mollusca). Tirion Natuur \& Stichting Anemoon. 416 pp.

Bucquoy E, Dautzenberg Ph, Dollfus G. 1884. Les Mollusques marins du Roussillon. 1: Gastropodes. - J.B. Bailliere et fils, Paris. 570 pp.

Bush KJ. 1899. Descriptions of new species of Turbonilla of the western Atlantic fauna, with notes on those previously known. Proceedings of the Academy of Natural Sciences of Philadelphia 52:145-177.

Bush KJ. 1909. Notes on the family Pyramidellidae. American Journal of Science (4) 27:475-484.

Cabioch L. 1968. Contribution a la connaissance des peuplements benthiques de la Manche Occidentale. Cahiers de Biologie Marine 95. Supplément: 493-720.

Cachia C, Mifsud C, Sammut PM. 2001. The Marine Mollusca of the Maltese Islands Part Three: Sub-class Prosobranchia to subclass Pulmonata, order Basommatophora. Backhuys Publishers, Leiden. 266 pp.

Carpenter P. 1856. Description of new species and varieties of Calyptræidæ, Trochidæ, and Pyramidellidæ, principally in the collection of Hugh Cuming, Esq. Proceedings of the Zoological Society of London 24 (1856):166-171.

Clark W. 1855. A History of the British marine testaceous Mollusca. John van Voorst, London. $536 \mathrm{pp}$.

CLEMAM 2009 (2014). Check List of European Marine Mollusca. [www.somali.asso.fr/clemam].

Cole HA, Hancock DA. 1955. Odostomia as a pest of oysters and mussels. Journal of the Marine biological Association of the United Kingdom 34:25-31.

Collin J. 1880. Faunula Molluscorum Marinorum Hellebækiana: Oversigt over den marine bløddyrfauna ved Hellebæk. Naturhistorisk Tidsskrift, 3. Rk. 12:421-423.

Collin J. 1884. Om Limfjordens tidligere og nuværende marine fauna, med særligt hensyn til bløddyrfaunaen. Gyldendalske Boghandels Forlag, Kjøbenhavn. 169 pp.

Corgan JX. 1973. The names Partulida Schaufuss, 1869, and Spiralinella Chaster, 1901 (Gastropoda: Pyramidellacea). Journal of Conchology 28:9-10.

Dall WH, Bartsch P. 1903. Page 273 in: Arnold R. The paleontology and stratigraphy of the marine Pliocene and Pleistocene of San Pedro California. Memoirs of the California Academy of Science 3:1-420

Dall WH, Bartsch P. 1904. Synopsis of the genera, subgenera and sections of the family Pyramidellidae. Proceedings of the Biological Society of Washington 17:1-16.

Danielssen DC. 1861. Beretning on en zoologisk reise foretagen i sommeren 1857. Nyt Magazin for Naturvidenskaberne 11:1-58.

Dautzenberg P, Fischer PH. 1912. Mollusques provenant des campagnes de l' Hirondelle et de la Princesse-Alice dans les Mers du Nord. Résultats des Campagnes Scientifiques 
accomplies sur son Yacht par Albert I 37:1-629.

Dautzenberg P, Fischer Ph. 1925. Les Mollusques Marins du Finistère et en particulier de la Région de Roscoff. Travaux de la Station Biologique de Roscoff 3:1-180.

Dillwyn LW. 1817. A descriptive catalogue of Recent shells, arranged according to the Linnean method. 2 vols, London [not seen].

Dinapoli A, Klussman-Kolb A. 2010. The long way to diversity: phylogeny and evolution of the Heterobranchia (Mollusca: Gastropoda). Molecular Phylogenetics and Evolution 55:60-76.

Dinapoli A, Zinssmeister C, Klussman-Kolb A. 2011. New insights into the phylogeny of the Pyramidellidae (Gastropoda). Journal of Molluscan Studies 77:1-7.

Donovan E. 1804. The natural history of British shells, including figures and descriptions of all the species hitherto discovered in Great Britain. Vol. 5. FC Rivington, London [not seen].

Fasseaux W. 1974. Chrysallida sarsi Nordsieck, une nouvelle espèce sur la côte Belge. Informations de la Societé Belge de Malacologie 3 (10):121-129.

Forbes E. 1844. Notice of some additions to the British fauna discovered by Robert MacAndrew, Esq., during the year 1844. Annals and Magazine of Natural History 14:410-415.

Forbes E. 1846. Notice of additions to the marine fauna of Britain discovered by Robert M'Andrew, Esq., since the last meeting of the association. Report of the Meeting of the British Association for the advancement of Science 15. meeting, 1845:130-193.

Forbes E, Hanley S. 1850-51. A History of British Mollusca and their Shells. Vol. 3, John van Voorst, London.

Forbes E, Hanley S. 1853. A History of British Mollusca and their Shells. Vol. 4, John van Voorst, London.

Forbes E, MacAndrew, R. 1846. Notes of new and rare animals observed during cruises in the British seas since the last meeting. Athenaeum 988:1027.

Fretter V, Graham A. 1949. The structure and mode of life of the Pyramidellidae, parasitic opisthobranchs. Journal of the Marine Biological Association of the United Kingdom 28:493-532.

Fretter V, Graham A, Andrews EB. 1986. The Prosobranch Molluscs of Britain and Denmark. Part 9 - Pyramidellacea. Journal of Molluscan Studies, Suppl. 16, pp. 557-649.

Friele H. 1874. Oversigt over de i Bergens omegn forekommende skaldækte mollusker. Christiania Videnskabs-Selskabs Forhandlinger for 1873:1-24.

Friele H. 1876. Bidrag til Vestlandets molluskfauna. Christiania Videnskabs-Selskabs Forhandlinger for 1875:57-64.

Friele H. 1886. Mollusca II. - The Norwegian North-Atlantic Expedition, 1876-1878. 3 (5):1-44; pl. VII to XII.

Friele H, Grieg JA. 1901. Mollusca III. The Norwegian NorthAtlantic Expedition, 1876-1878. 7 (5):1-128.

Gibbs PE. 1978. Menestho diaphana (Gastropoda) and Montacuta phascolionis (Lamellibranchia) in association with the sipunculan Phascolion strombi in British waters. Journal of the Marine Biological Association of the United Kingdom 58:683685.

Graham A. 1988. Molluscs: Prosobranch and Pyramidellid Gastropods. Synopses of the British Fauna (New Series). No. 2 (Second Edition). E.J. Brill/Dr. W. Backhuys. 662 pp.

Grieg JA. 1888. Undersøgelser over dyrelivet i de vestlandske fjorde. I. Moster. Bergens Museums Aarbog 1887(3):1-16.

Grieg JA. 1897. Bidrag til kundskaben om Vestlandets mollusker. I. Sognesøens mollusker. Bergens Museums Aarbog 1896(10):125.

Grieg JA. 1898. Skrabninger i Vaagsfjorden og Ulvesund, ytre Nordfjord. Bergens Museums Aarbog 1897(16):1-27.
Grieg JA. 1913. Marine mollusker fra Indre Sogn. Nyt Magazin for Naturvidenskaberne 51:1-42

Grieg JA. 1914. Bidrag til kundskapen om Hardangerfjordens fauna. Bergens Museums Aarbok 1913(1):1-147.

Grieg JA. 1915. Evertebratfaunaen paa havdypet utenfor "Tampen". Bergens Museums Aarbok 1914(3):1-26.

Hanley S. 1844. Description of new species of recent shells. Proceedings of the Zoological Society of London 1844:14-18.

Hansson HG. 1998. NEAT Mollusca. In North East Atlantic Taxa. http://www.tmbl.gu.se/libdb/taxon/taxa.html

Høisæter T. 1965. Spermatophores in Chrysallida obtusa Brown. Opisthobranchia, Pyramidellidae. Sarsia 18:63-68.

Høisæter T. 1968. Skenea nitens, Ammonicera rota, Odostomia lukisi, and Eulimella nitidissima, small marine gastropods new to the Norwegian fauna. Sarsia 31:25-34.

Høisæter T. 1986. An annotated check-list of marine molluscs of the Norwegian coast and adjacent waters. Sarsia 71:73-145.

Høisæter T. 1989. Biological notes on some Pyramidellidae (Gastropoda: Opisthobranchia) from Norway. Sarsia 74:283-297.

Høisæter T. 2009. Distribution of marine, benthic, shell bearing gastropods along the Norwegian coast. Fauna norvegica 28:5106.

Høisæter T. 2010. The shell-bearing, benthic gastropods on the southern part of the continental slope off Norway. Journal of Molluscan Studies 76:234-244.

Hori S. 2000. Superfamily Pyramidelloidea. Pp. 703-731 in Okutani, T. Ed. Marine Mollusks in Japan. Tokai University Press, Tokio. 1174 pp.

Hori S, Kuroda R. 2001. Spermatophores in Iolaea scitula A. Adams, 1860. (Gastropoda, Heterobranchia, Pyramidellidae). Basteria 65:131-137

Hylleberg Kristensen J. 1970. Fauna associated with the sipunculoid Phascolion strombi Montagu., especially the parasitic gastropod Menestho diaphana Jeffreys. Ophelia 7:257-276.

ICZN 1999. International code of Zoological Nomenclature. Fourth Edition. The International Trust for Zoological Nomenclature. $306 \mathrm{pp}$

Iredale T. 1915. Notes on the names of some British marine Mollusca. Proceedings of the Malacological Society of London 11:329-342.

Iredale T. 1917. More molluscan name changes, generic and specific. Proceedings of the Malacological Society of London 12:322-330.

Jeffreys JG. 1847. Descriptions and notices of British shells. Annals and Magazine of Natural History, Ser. 1. 19:309-314.

Jeffreys JG. 1848. On the recent species of Odostomia, a genus of Gasteropodous Mollusks inhabiting the seas of Great Britain and Ireland. Annals and Magazine of Natural History, Ser. 2. 2:330-351.

Jeffreys JG. 1849. Notice of some mollusca recently taken by George Barlee, Esq., off Lerwick. Annals and Magazine of Natural History, Ser. 2. 4:299-300.

Jeffreys JG. 1859. Further gleanings in British Conchology. Annals and Magazine of Natural History, Ser. 3. 3:30-43, 106-120.

Jeffreys JG. 1867. British Conchology. Vol. 4. Marine Shells. John van Voorst, London. 486 pp.

Jeffreys JG. 1869. British Conchology. Vol. 5. Supplement. John van Voorst, London. $258 \mathrm{pp}$.

Jeffreys JG. 1870. Norwegian Mollusca. Annals and Magazine of Natural History, Ser. 4. 5:438-448.

Jeffreys JG. 1884. On the Mollusca procured during the 'Lightning' and 'Porcupine' Expeditions, 1868-70. Part VIII. Proceedings of the zoological Society of London 1884:341-371. 
Kaldhol H. 1909. Et bidrag til faunaen i Vestlandets kvartærafleiringer. Bergens Museums Aarbok 1908 (6):1-48.

Kantor Yu, Sysoev AV. 2006. Marine and brackish water Gastropoda of Russia and adjacent countries: an illustrated catalogue. KMK Scientific Press Ltd., Moscow, 371 pp. and 140 plates.

Kobelt W. 1903. Familie Pyramidellidae. Pp. 64 to 172 in: Iconographie der schalentragenden europäischen Meeresconchylien. III. C.W. Kreidel's Verlag, Wiesbaden. 406 pp.

Kolderup CF. 1908. Bergensfeltet og tilstødende trakter i senglacial og postglacial tid. Bergens Museums Aarbok 1907 (14):1-266.

Leche W. 1878. Öfversigt öfver de af Svenska Expeditionerna till Novaja Somlja och Jenissej 1875 och 1876 Insamlade Hafs-Mollusker. Kungliga Svenska Vetenskapsakademiens Handlingar 16(2):1-86.

Linden J van der, Eikenboom JCA. 1992. On the taxonomy of the recent species of the genus Chrysallida Carpenter from Europe, the Canary Islands and the Azores (Gastropoda, Pyramidellidae). Basteria 56:3-63.

Lovén S. 1846a. Malacologiska notiser. Om de nordiske arterna af Turbonilla. Öfversigt af Kongliga Vetenskaps-Akademiens Förhandlinger, 3. årgangen, 1846:46-50.

Lovén S. 1846b. Norden Hafs-Mollusker. Index Molluscorum litora Scandinaviae occidentalis habitantium. Öfversigt af Kongliga Vetenskaps-Akademiens Förhandlinger, 3. årgangen, 1846:134-160.

Maas D. 1964. Über Cuticularbildungen am Penis von Pyramidelliden. Zoologischer Anzeiger 173:137-148.

Maas D. 1965. Anatomische und histologische Untersuchungen am Mundapparat der Pyramidelliden. Zeitschrift für Morphologie und ökologie der Tiere 54:566-642.

Macgillivray W. 1844. A history of the Molluscous and Cirripedal specimens of Scotland. 2. Ed., Cunningham, Aberdeen. [Not seen].

Malm AW. 1855. Malakozoologiske Bidrag till Skandinavisk Fauna. Göteborgs Kungliga Vetenskaps och Vitterhets Samhälles Handlingar, ny tidsf. 1855(3):1-47. [Not seen].

Malm AW. 1861. Fiske, Krebsdyr og Bløddyr nye for den skandinaviske fauna. Forhandlinger ved de Skandinaviske Naturforskeres ottende Møde i Kiøbenhavn Juli 1860:616-624.

Marshall JT. 1893. Additions to "British Conchology". Journal of Conchology 7:241-265.

Marshall JT. 1894. Additions to "British Conchology". Addenda. Journal of Conchology 7:379-385.

Marshall JT. 1899a. Additions to "British Conchology". Journal of Conchology 9:165-171.

Marshall JT. 1899b. Additions to "British Conchology". Journal of Conchology 9:222-232.

Marshall JT. 1900. Additions to "British Conchology". Journal of Conchology 9:284-296, 332-338.

Marshall JT. 1918. Additions to "British Conchology". Journal of Conchology 15:168-174.

Maton WG, Rackett T. 1807. A descriptive catalogue of the British Testacea. Transactions of the Linnean Society of London 8: 17-250 [not seen].

McAndrew R, Barrett L. 1856. List of the Mollusca observed between Drontheim and the North Cape. Annals and Magazine of Natural History, Ser. 2, 17:378-386.

McFadden YMT, Myers AA. 1989. The life history and reproductive biology of Odostomia eulimoides (Gastropoda: Opisthobranchia) on the south coast of Ireland. Journal of the Marine Biological Association of United Kingdom 69:65-80.
McKay DW, Smith SM. 1979. Marine Mollusca of East Scotland. - Published by the Royal Scottish Museum, Edinburgh. 185 pp.

Micali P, Nofroni I, Aartsen JJ van. 1993. Additions to the knowledge of the European Chrysallida species, with notes on a recent work by Van der Linden, Eikenboom (Gastropoda, Opisthobranchia). Basteria 57:147-154.

Montagu G. 1803. Testacea Britannica; or natural history of British Shells. Part I. - J. White, London. 606 pp.

Montagu G. 1808. Testacea Britannica; or natural history of British Shells. Supplement. - J. White, London. 183 pp.

Monterosato TA di. 1884. Nomenclatura generica e specifica di alcune conchiglie Mediterranee. Stabilimento Tipografico Virzi, Palermo. $152 \mathrm{pp}$.

Mørch OAL. 1871. Synopsis Molluscorum Marinorum Daniae. Videnskabelige Meddelelser fra den Naturhistoriske Forening i København 1871:11-14. [Not seen].

Nekhaev IO. 2011. Two species of parasitic molluscs new for Russian seas. Ruthenica 21:69-72

Nordgaard O. 1905. Gastropoda, pp. 178 to 181: in Nordgaard O, Jørgensen E. Hydrographical and Biological Investigations in Norwegian Fiords. Bergens Museums Skrifter 7.

Nordgaard O. 1913. Foraminiferer og mollusker fra de vestlandske fjorde. Kongelige Norske Videnskabers Selskabs Skrifter 1912(11):1-23.

Nordsieck F. 1972. Die Europäischen Meeresschnecken Opisthobranchia mit Pyramidellidae; Rissoacea. Gustav Fischer, Stuttgart. 327 pp.

Norman AM. 1879. The mollusca of the fiords near Bergen, Norway. Journal of Conchology 2:8-77.

Norman AM. 1893. A month on the Trondhjem Fiord. Annals and Magazine of Natural History Ser. 6, 12:341-367.

Norman AM. 1902. Notes on the natural history of East Finmark. Annals and Magazine of Natural History Ser. 7, 10:341-361.

Odhner NH. 1915. Die Molluskenfauna des Eisfjordes. Zoologische Ergebnisse der Schwedischen Expedition nach Spitzbergen 1908. Teil II (1). Kungliga Svanska Vetenskapsakademiens Handlingar 54(1), 274 pp.

Olesen M editor. 2005. Naturforholdene i havet omkring Læsø. Pilotprojekt Marin Nationalpark Læsø. [http://www.mbl.ku.dk/ molesen/L\%C3\%A6s\%C3\%B8\%20 rapport 13.pdf]

Öztürk B, Bitlis Bakir B, Micali P. 2013. Heterostropha Species of the Turkish Coasts: Odostomiinae Pelseneer, 1928 (Gastropoda, Heterobranchia, Pyramidellidae). Turkish Journal of Fisheries and Aquatic Sciences 13:139-157.

Öztürk B, Bitlis Bakir B. 2013. Heterostropha Species of the Turkish Coasts: Anisocycla, Eulimella, Puposyrnola and Turbonilla (Gastropoda, Heterobranchia). Turkish Journal of Fisheries and Aquatic Sciences 13:423-440.

Palmer KVW. 1958. Type specimens of marine mollusca described by PP Carpenter from the west coast. Memoir Geological Society of America 76:1-376.

Parker WK, Jones TR. 1860. On the Nomenclature of the Foraminifera. II On the species enumerated by Walker and Montagu. Annals and Magazine of Natural History, Series 3, 4:333-351.

Pelseneer, P. 1928. Les parasites des mollusques et les mollusques parasites. Bulletin de la Société Zoologique de France 53:158189.

Peñas A, Rolán E. 1998. La Familia Pyramidellidae Gray, 1840 (Mollusca, Gastropoda, Heterostropha). en África Occidental. 3. El género Chrysallida s.l. Iberus, Supplemento 4: 1-73.

Peñas A, Rolán E. 2001. La superfamilia Pyramidelloidea Gray, 1840 (Mollusca, Gastropoda, Heterostropha) en África 
Occidental. 8. Los géneros Bacteridium y Anisocycla. Iberus 19: $53-63$

Peñas A, Templado J, Martínez JL. 1996. Contribución al conocimiento de los Pyramidelloidea (Gastropoda: Heterostropha) del Mediterráneo español. Iberus 14(1): 1-82.

Petersen CGJ. 1888. Om de skalbarende Molluskers Udbredningsforhold $i$ de danske Have indenfor Skagen. Doctoral Thesis, København. 162 pp.

Pinna G, Spezia L. 1978. Catalogo dei Tipi del Museum Civico di Storia Naturale di Milano. V. I Tipi dei Gasteropodi fossili. Atti Soc. ital. Sci nat. Museum civico di Storia Naturale di Milano 119:125-180.

Ponder WF. 1973. Pseudoskenella depressa gen. et sp. nov., an ectoparasite on Galeolaria. Malacological Review 6:119-123.

Ponder WF \& Warén A. 1988. Classification of the Caenogastropoda and Heterostropha - a list of the family-group names and higher taxa. Malacological Review. Supplement 4:288-328.

Rasmussen E. 1973. Systematics and ecology of the Isefjord marine fauna Denmark. Ophelia 11:1-507.

Robertson R. 1966. The life history of Odostomia bisuturalis, and Odostomia spermatophores (Gastropoda: Pyramidellidae). Year Book of The American Philosophical Society, Geological and biological Sciences 1966:368-369.

Robertson R. 1967. Hosts, spermatophores, and the systematics of five East American species of Odostomia, s.l. (Gastropoda: Pyramidellidae). Annual report of the American malacological union 1967, 12-13.

Robertson R. 1978. Spermatophores of six eastern North american Pyramidellid Gastropods and their systematic significance with the new genus Boonea. Biological Bulletin 155:360-382.

Robertson R. 1996. Fargoa bartschi Winkley, 1909.: a little-known Atlantic and Gulf coast American odostomian Pyramidellidae. and its generic relationships. American Malacological Bulletin 13:11-21.

Robertson R, Mau-Lastovicka T. 1979. The ectoparasitism of Boonea and Fargoa (Gastropoda: Pyramidellidae). Biological Bulletin 157:320-333.

Rodriguez Babio C, Thiriot-Quiévreux C. 1974. Gastéropodes de la région de Roscoff. Étude particulière de la protoconque. Cahiers de Biologie Marine 15:531-549.

Rodriguez Babio C, Thiriot-Quiévreux C. 1975. Pyramidellidae, Philinidae et Retusidae de la région de Roscoff. Étude particulière des protoconques de quelques espéces. Cahiers de Biologie Marine 16:83-96.

Rolan Mosquera E. 1983. Moluscos de la Ria de Vigo. 1. Gasteropodos. Thalassas 11. Anexo 1:1-383.

Rosenberg G. 2009. Malacolog 4.1.1: A Database of Western Atlantic Marine Mollusca. [WWW database (version 4.1.1)] URL http://www.malacolog.org/.

Sars GO. 1878. Bidrag til Kundskaben om Norges arktiske Fauna. I. Mollusca Regionis Arcticae Norvegiae. - Universitets program for første halvaar 1878. Christiania. $466 \mathrm{pp}$.

Sars M. 1851. Beretning om en i sommeren 1849 foretagen zoologisk reise i Lofoten og Finmarken. Nyt Magazin for Naturvidenskaberne 6:121-211.

Sars M. 1853. Bemærkninger over det adriatiske havs fauna sammenlignet med Nordhavets. Nyt Magazin for Naturvidenskaberne 7:367-397.

Sars M. 1865. Om de i Norge forekommende fossile dyrelevninger fra qvartærperioden. Universitetsprogram for første halvaar 1864. Christiania. 134 pp.

Sars M. 1869. Remarks on the distribution of animal life in the depths of the sea. Annals and Magazine of Natural History, Ser.
4, 3:423-441

Sars M. 1870. Bidrag til Kundskab om Christianiafjordens Fauna. Nyt Magazin for Naturvidenskaberne 17:113-226.

Schander C. 1994. Twenty-eight new species of Pyramidellidae (Gastropoda, Heterobranchia) from West Africa. Notiziario CISMA 15:11-78.

Schander C. 1995. Pyramidellidae (Mollusca, Gastropoda, Heterobranchia) of the Faroe Islands. Sarsia 80:55-64.

Schander C. 1997. Taxonomy and phylogeny of the Pyramidellidae (Mollusca, Gastropoda, Heterobranchia). Akademisk Avhandling Ph.D.-thesis. Department of Zoology, Göteborg University, Göteborg.

Schander C, van Aartsen JJ, Corgan JX. 1999. Families and genera of the Pyramidelloidea (Mollusca: Gastropoda). Bollettino Malacologico 34:145-166

Schander C, Halanych KM, Dahlgren T, Sundberg P. 2003. Test of the monophyly of Odostomiinae and Turbonilliinae (Gastropoda, Heterobranchia, Pyramidellidae) based on $16 \mathrm{~S}$ mtDNA sequences. Zoologica Scripta 32:243-254.

Schander C, Hori S, Lundberg J. 1999b. Anatomy and phylogeny of Odostomella and Herviera Mollusca, Heterogastropoda, Pyramidellidae. with a description of Odostomella. Ophelia 51:39-76.

Schander C, Sundberg P. 2001. Useful characters in gastropod phylogeny. Soft information or hard facts? Systematic Biology 50:136-141

Schneider J Sparre. 1886. Undersøgelser af dyrelivet i de arktiske fjorde. III. Tromsøsundets molluskfauna. Tromsø Museums Aarshefter 9:1-50.

Schiøtte T, Warén A. 1992. An annotated and illustrated list of the types of Mollusca described by H.P.C. Møller from West Greenland. Meddelelser om Grønland, Bioscience 35:1-34.

Seaward DR. 1982. Sea Area Atlas of the Marine Molluscs of Britain and Ireland. Nature Conservancy Council, Interpretative Branch, Shrewsbury. 242 pp.

Seaward DR. 1990. Distribution of the marine molluscs of north west Europe. Nature Conservancy Council, Marine Science Branch, Peterborough. 114 pp.

Smith SM, Heppell D. 1991. Checklist of British Marine Mollusca. National Museums of Scotland Information Series 11:1-114.

Sneli JA. 1972. Odostomia turrita found on Homarus gammarus. Nautilus 86:23-24.

Thiele J. 1925. Gastropoden der Deutschen Tiefsee-Expedition. Wissenschaftliche Ergebnisse der Deutschen Tiefsee-Expedition auf dem Dampfer "Valdivia" 1898-1899. 17 (2):35-382.

Thiele J. 1928. Arktische Loricaten, Gastropoden, Scaphopoden und Bivalven. Fauna Arctica 5:563-632

Thiele J. 1929. Handbuch der systematischen Weichtierkunde. Band 1 (1). Gustav Fischer, Jena. 376 pp.

Thompson W. 1840. Contributions towards a knowledge of the Mollusca Nudibranchia and Mollusca Tunicata of Ireland, with descriptions of some apparently new species of Invertebrata. Annals and Magazine of Natural History 5:84-102.

Thompson W. 1844. Report on the fauna of Ireland: Div. Invertebrata. Report of the thirteenth meeting of the British Association for the Advancement of Science:245-255.

Thompson W. 1845. Additions to the fauna of Ireland, including descriptions of some apparently new species of Invertebrata. Annals and Magazine of Natural History 15:308-322.

Thorson G. 1946. Reproduction and larval development of Danish marine bottom invertebrates. Meddelelser fra kommissionen for Danmarks Fiskeri- og Havundersøgelser. Serie: Plankton 4(1):1-523 
Tryon GW. 1886. Manual of Conchology. Vol. VIII. Naticidæ, Calyptræidæ, Turritellidæ, Vermetidæ, Cæcidæ, Eulimidæ, Turbonillidæ, Pyramidellidæ. Philadelphia, Pennsylvania. 461 pp.

Verkrüzen TA. 1875. Bericht über einen Schabe-Ausflug im Sommer 1874. Jahrbücher der Deutschen Malakozoologischen Gesellschaft 2:229-240.

Warén A. 1980. Marine Mollusca described by John Gwyn Jeffreys, with the location of the type material. Conchological Society Special Publication 1:1-60.

Warén A. 1989. New and little known Mollusca from Iceland. Sarsia 74:1-28.

Warén A. 1991. New and little known Mollusca from Iceland and Scandinavia. Sarsia 76:53-124.

Warén A. 1993. New and little known Mollusca from Iceland and Scandinavia. Part 2. Sarsia 78:159-201.

Warén A. 1995. Systematic position and validity of Ebala Gray, 1847 (Ebalidae Fam. N., Pyramidelloidea, Heterobranchia). Bollettino Malacologico 30:203-210.

Wharton RA. 1976. Variation in the New England pyramidellid gastropod, Turbonilla nivea Stimpson. The Nautilus 90:11-13.

Winckworth R. 1932. The British marine Mollusca. Journal of Conchology 19:211-252.

Wise JB. 1996. Morphology and phylogenetic relationships of certain pyramidellid taxa Heterobranchia. Malacologia 37:443511.

Wise JB. 2001. Anatomy of Boonea jadisi Olsson and McGinty, 1958. Heterobranchia: Pyramidellidae. from the western Atlantic, with comparisons to other species in the genus. Nautilus 115:68-75.

Editorial responsibility: Torkild Bakken.

This article is open-access and distributed under the terms of the Creative Commons Attribution-Noncommercial 3.0 Unported License (http://creativecommons.org/licenses/by-nc/3.0/). This permits all non-commercial use, distribution, and reproduction in any medium, provided the original work is properly cited. 